Organisation de Coopération et de Développement Économiques

Organisation for Economic Co-operation and Development

11-Jul-2014

ENVIRONMENT DIRECTORATE

English - Or. English

JOINT MEETING OF THE CHEMICALS COMMITTEE AND

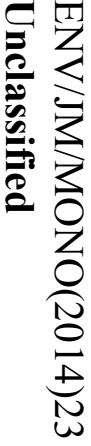

THE WORKING PARTY ON CHEMICALS, PESTICIDES AND BIOTECHNOLOGY

NEW SCOPING DOCUMENT ON IN VITRO AND EX VIVO ASSAYS FOR THE IDENTIFICATION OF MODULATORS OF THYROID HORMONE SIGNALLING

Series on Testing and Assessment

No. 207

Complete document available on OLIS in its original format

This document and any map included herein are without prejudice to the status of or sovereignty over any territory, to the delimitation of international frontiers and boundaries and to the name of any territory, city or area. 


\section{ENV/JM/MONO(2014)23}


OECD Environment, Health and Safety Publications

Series on Testing and Assessment

No. 207

NEW SCOPING DOCUMENT ON IN VITRO AND EX VIVO ASSAYS FOR THE IDENTIFICATION OF MODULATORS OF THYROID HORMONE SIGNALLING 


\begin{abstract}
About the OECD
The Organisation for Economic Co-operation and Development (OECD) is an intergovernmental organisation in which representatives of 34 industrialised countries in North and South America, Europe and the Asia and Pacific region, as well as the European Commission, meet to co-ordinate and harmonise policies, discuss issues of mutual concern, and work together to respond to international problems. Most of the OECD's work is carried out by more than 200 specialised committees and working groups composed of member country delegates. Observers from several countries with special status at the OECD, and from interested international organisations, attend many of the OECD's workshops and other meetings. Committees and working groups are served by the OECD Secretariat, located in Paris, France, which is organised into directorates and divisions.
\end{abstract}

The Environment, Health and Safety Division publishes free-of-charge documents in eleven different series: Testing and Assessment; Good Laboratory Practice and Compliance Monitoring; Pesticides; Biocides; Risk Management; Harmonisation of Regulatory Oversight in Biotechnology; Safety of Novel Foods and Feeds; Chemical Accidents; Pollutant Release and Transfer Registers; Emission Scenario Documents; and Safety of Manufactured Nanomaterials. More information about the Environment, Health and Safety Programme and EHS publications is available on the OECD's World Wide Web site (http://www.oecd.org/chemicalsafety/).

This publication was developed in the IOMC context. The contents do not necessarily reflect the views or stated policies of individual IOMC Participating Organisations.

The Inter-Organisation Programme for the Sound Management of Chemicals (IOMC) was established in 1995 following recommendations made by the 1992 UN Conference on Environment and Development to strengthen co-operation and increase international co-ordination in the field of chemical safety. The Participating Organisations are FAO, ILO, UNDP, UNEP, UNIDO, UNITAR, WHO, World Bank and OECD. The purpose of the IOMC is to promote co-ordination of the policies and activities pursued by the Participating Organisations, jointly or separately, to achieve the sound management of chemicals in relation to human health and the environment. 
This publication is available electronically, at no charge.

Also published in the Series on Testing and Assessment link

For this and many other Environment, Health and Safety publications, consult the OECD's World Wide Web site (www.oecd.org/chemicalsafety/)

or contact:

OECD Environment Directorate, Environment, Health and Safety Division

2 rue André-Pascal

75775 Paris Cedex 16

France

Fax: (33-1) 44306180

E-mail: ehscont@oecd.org

Applications for permission to reproduce or translate all or part of this material should be made to: Head of Publications Service, RIGHTS@oecd.org, OECD, 2 rue AndréPascal, 75775 Paris Cedex 16, France 


\section{FOREWORD}

This new scoping document aims at bringing forward relevant in vitro and ex vivo thyroid assays to the attention of OECD member countries, to provide recommendations for their development/use, and also, to identify aspects/blocks of the thyroid signalling pathways that are not covered and would require further development of thyroid assays.

The scoping document was prepared by a group of experts coming from the OECD Validation Management Group on Non-Animal Testing and the OECD Expert Group on Amphibian Testing, all working under the auspices of the OECD Test Guidelines Programme. The present document was approved by the Working Group of the National Coordinators of the Test Guidelines Programme (WNT) at their $26^{\text {th }}$ meeting in April 2014. The Joint Meeting of the Chemicals Committee and the Working Party on Chemicals, Pesticides and Biotechnology agreed to its declassification on $7^{\text {th }}$ July, 2014.

This document is published under the responsibility of the Joint Meeting of the Chemicals Committee and the Working Party on Chemicals, Pesticides and Biotechnology. 


\section{TABLE OF CONTENTS}

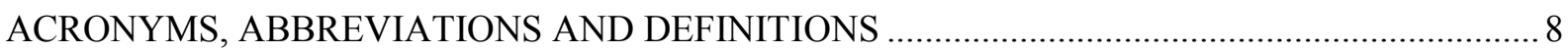

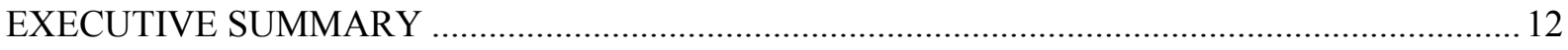

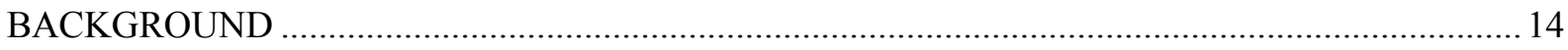

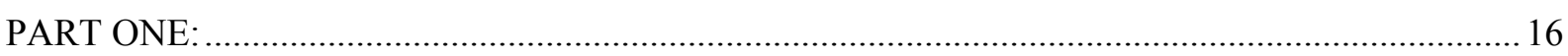

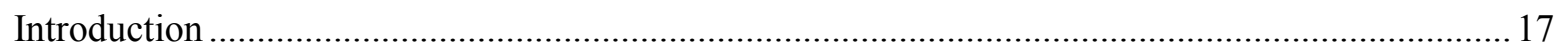

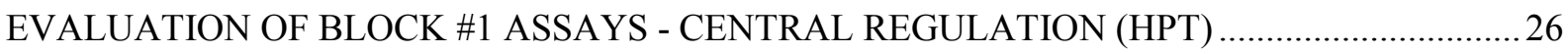

Hypothalamic Thyrotropin-Releasing Hormone (TRH) Production/Release ....................................2 27

Pituitary - Thyrotropin-Releasing Hormone (TRH) Receptor Activation Assay ...............................29

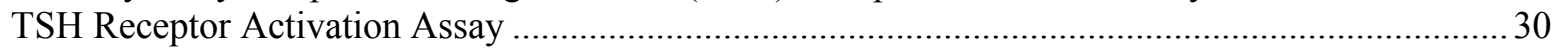

EVALUATION OF BLOCK \#2 ASSAYS - THYROID HORMONE SYNTHESIS ............................ 31

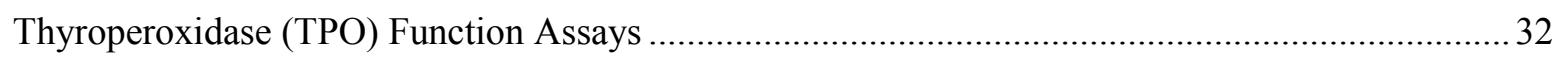

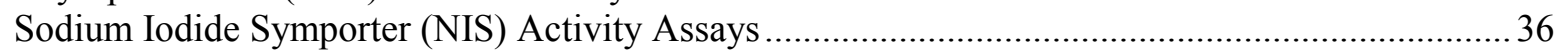

EVALUATION OF BLOCK \#3 ASSAYS - BINDING AND TRANSPORT IN SERUM ................. 39

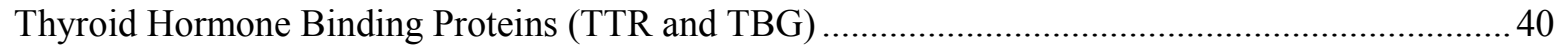

EVALUATION OF BLOCK \#4 ASSAYS - METABOLISM AND EXCRETION .............................42

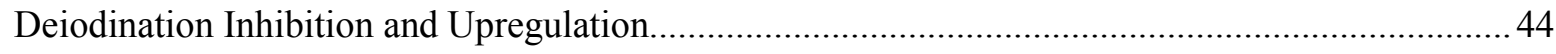

EVALUATION OF BLOCK \#5 ASSAYS - LOCAL CELLULAR CONCENTRATIONS ................ 48

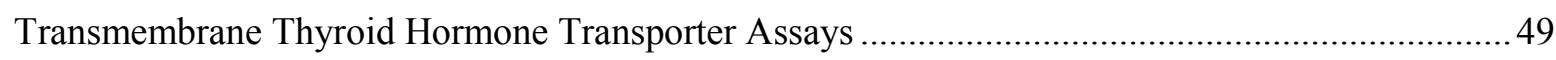

EVALUATION OF BLOCK \#6 ASSAYS - CELLULAR RESPONSES …...........................................52

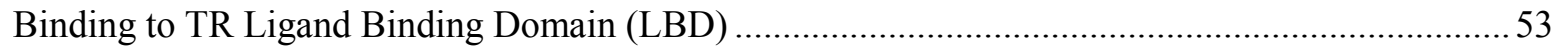

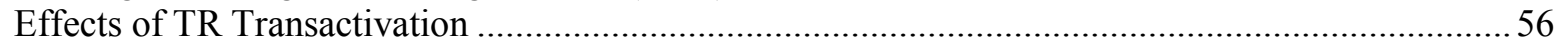

EVALUATION OF BLOCK \#7 ASSAYS - RELEVANT SHORT-TERM ASSAYS INTEGRATING

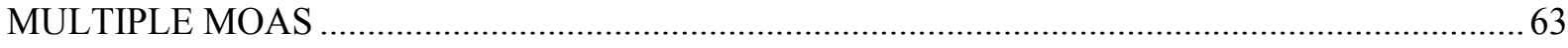

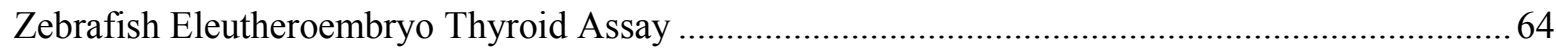

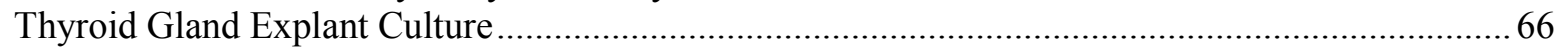

EVALUATION OF BLOCK \#8 ASSAYS - INTEGRATIVE CELLULAR ASSAYS.......................68

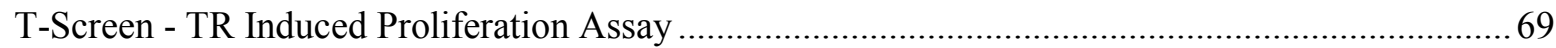

Human Neural Progenitor Cell Proliferation/Differentiation/Migration............................................. 70

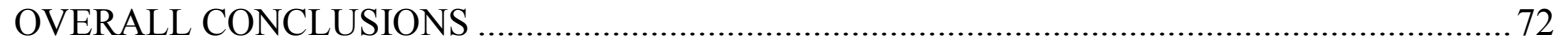

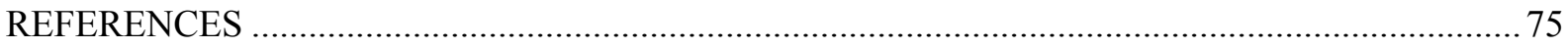




\section{ACRONYMS, ABBREVIATIONS AND DEFINITIONS}

ADME Absorption, distribution, metabolism and excretion

AhR aryl hydrocarbon receptor

AMA Amphibian Metamorphosis Assay (OECD TG 231)

AOP

adverse outcome pathway AOP is a sequence of events from the exposure of an individual or population to a chemical substance through a final adverse (toxic) effect at the individual level (for human health) or population level (for ecotoxicological endpoints).

AR

androgen receptor

Assay An experimental system that can be used to obtain a range of information from chemical properties through the adverse effects of a substance. The terms 'assay' and 'test method' may be used interchangeably for wildlife as well as for mammalian studies (OECD, 2005)

$\begin{array}{ll}\text { ATPase } & \text { adenosine triphosphatase } \\ \text { BDE } & \text { brominated diphenyl ether } \\ \text { BDE-47 } & 2,2 \text { ',4,4'-tetrabromodiphenylether } \\ \text { BIAC } & \text { Business and Industry Advisory Committee } \\ \text { BPA } & \text { bisphenol A } \\ \text { cAMP } & \text { cyclic adenosine monophosphate } \\ \text { CAR } & \text { constitutive androstane receptor } \\ \text { CAT } & \text { chloramphenicol actyltransferase } \\ \text { CCD } & \text { charged couple device } \\ \text { CDCA } & \text { chenodeoxycholic acid } \\ \text { CERI } & \text { Chemicals Evaluation Research Institute, Japan } \\ \text { CF } & \text { Conceptual Framework } \\ \text { CNS } & \text { central nervous system } \\ \text { CoR } & \text { co-repressors } \\ \text { CCV } & \text { coefficient of variation } \\ \text { CYP } & \text { cytochrome P450 } \\ \text { D1 } & \text { Type I deiodinase } \\ \text { D2 } & \text { Type II deiodinase } \\ \text { D3 } & \text { Type III deiodinase } \\ \text { DEX } & \text { dexamethasone } \\ \text { DHT } & \text { dihydrotestosterone } \\ \text { DNA } & \text { Deoxyribonucleic acid } \\ \text { DRP } & \text { detailed review paper } \\ \text { DUOX 2 } & \text { dual oxidase 2 } \\ \text { EAS } & \text { Endocrine Active Substances } \\ \text { ED } & \text { Endocrine Disruptor } \\ \text { EDC } & \text { endocrine disrupting chemical } \\ \text { EDSP } & \text { Endocrine Disruptor Screening Program } \\ & \end{array}$




$\begin{array}{ll}\text { EDTA } & \text { Endococrine Disrupter Testing and Assessment } \\ \text { EDTA AG } & \text { Endocrine Disruption Testing and Assessment Advisory Group } \\ \text { ER } & \text { estrogen receptor } \\ \alpha \text { GSU } & \text { glycoprotein-hormone } \alpha \text {-subunit } \\ \text { GD } & \text { Guidance Document } \\ \text { GEN } & \text { Genistein } \\ \text { GFP } & \text { Green Fluorescent Protein } \\ \text { GH } & \text { growth hormone } \\ \text { GH3 } & \text { pituitary tumour-cell line } \\ \text { GFP } & \text { Green Fluorescent Protein } \\ \text { HBCD } & \text { Hexabromocyclododecane } \\ \text { hNPC } & \text { human neural progenitor cell } \\ \text { HPT } & \text { hypothalamo-pituitary-thyroidal } \\ \text { HPT axis } & \text { Hypothalamic/pituitary/thyroid axis } \\ \text { HTP } & \text { High Throughput } \\ \text { HRE } & \text { Hormone Response Element } \\ \text { HPLC } & \text { High Performance or High Pressure Liquid Chromatography } \\ \text { Iodothyronines } & \text { Iodinated derivatives of thyronine (this also includes metabolites) }\end{array}$

Indicators of These are endpoints in an in vivo assay which show whether or not the endocrine Hormonal system has been stimulated, and often provide information of mechanistic value. activity In other words, they are not apical endpoints (see definition above). It is possible in some cases for indicators of hormonal activity to respond to a test chemical while apical endpoints do not respond, while in other cases, both types of endpoint give a response or only apical endpoints respond.

In vivo assay Assay where a whole live animal is treated. This may be a mammalian assay where individual animals are treated or a wildlife assay where a population of animals is treated

In vitro assay Assay where whole live animals are not used. Systems used may include cell lines or subcellular preparations from untreated animals

$\begin{array}{ll}\text { IOP } & \text { iopanoate } \\ \text { IRD } & \text { Inner-ring deiodinases } \\ \mathrm{K}^{+} & \text {potassium ion } \\ \text { LBD } & \text { ligand-binding domain } \\ \text { MCT } & \text { monocarboxylate transporter } \\ \text { MCT8 } & \text { monocarboxylate transporter } 8 \\ \text { MFA } & \text { meclofenamic acid } \\ \text { MIT } & \text { mono-iodothyronine } \\ \text { MMI } & \text { methimazole }\end{array}$

MOA Mode of action: The sequence of key events and cellular and biochemical events (measurable parameters), starting with the interaction of an agent with the target cell, through functional and anatomical changes, resulting in cancer or other 
adverse health effects.

\begin{tabular}{|c|c|}
\hline $\mathrm{Na}^{+}$ & sodium ion \\
\hline NCoR & nuclear receptor corepressor \\
\hline $\mathrm{NIH}$ & National Institutes of Health \\
\hline NIS & sodium-iodide symporter \\
\hline NOEC & No-Observed-Effect-Concentration \\
\hline NR & nuclear receptor \\
\hline NRs & nuclear receptors \\
\hline OATP & organic ion transport proteins \\
\hline OECD & Organization for Economic Cooperative Development \\
\hline OECD TG & OECD Test Guideline \\
\hline ORD & Outer-ring deiodinases \\
\hline P450 & cytochrome $\mathrm{P} 450$ \\
\hline PACAP & pituitary adenylate cyclase-activating peptide \\
\hline PAH & polycyclic aromatic hydrocarbon \\
\hline PBB & polybrominated biphenyl \\
\hline PBDE & Polybrominated Diphenyl Ether \\
\hline PBPK & physiologically based pharmacokinetic \\
\hline PCB & polychlorinated biphenyl \\
\hline PCDD & polychlorinated dibenzo- $p$-dioxin \\
\hline PCDF & polychlorinated dibenzofuran \\
\hline PFOS & perfluorooctane sulfonate \\
\hline PKA & phosphokinase A \\
\hline PKC & protein kinase $\mathrm{C}$ \\
\hline PLC & phospholipase C \\
\hline PPAR & peroxisome proliferator activated receptor \\
\hline PP assay & Peripubertal assay (male or female) \\
\hline PRL & prolactin \\
\hline PTU & propylthiouracil \\
\hline PVN & paravocellular nucleus \\
\hline PXR & pregnane $\mathrm{X}$ receptor \\
\hline qPCR & real-time polymerase chain reaction \\
\hline (Q)SAR & (Quantitative) Structure Activity Relationship \\
\hline RAR & retinoic acid receptor \\
\hline REACH & Registration, Evaluation, Authorisation \& Restriction of CHemicals \\
\hline RIA & radioimmunoassay \\
\hline RIC20 & relative inhibitory concentration \\
\hline $\mathrm{RN}$ & raphe nucleus \\
\hline RPA & Ribonuclease protection assay \\
\hline RT-PCR & Real-time Polymerase Chain Reaction \\
\hline RXR & retinoid $\mathrm{X}$ receptor \\
\hline SMRT & silencing mediator for retinoid and thyroid hormone receptors \\
\hline SON & supraoptic nucleus \\
\hline SPSF & Standard Project Submission Form \\
\hline SULT & Sulphotransferase \\
\hline
\end{tabular}


T3 thyroid hormone, triiodothyronine

T4 thyroid hormone, thyroxine

TBBPA 3,3',5,5'-tetrabromobisphenol A

TBG Thyroid hormone-binding globulin

TBTO tributyltin oxide

TCBPA 3,30,5,50-tetrachlorobisphenol A

TCDD tetrachlorodibenzo- $p$-dioxin

TD thyroid disruptor

TDC thyroid disrupting compound

Tg Thyroglobulin

TG test guideline

TH thyroid hormone

TIF2 transcriptional intermediary factor

TMBPA tetramethylbisphenol A

TPO thyroid peroxidase

TR thyroid hormone receptor

TRAP tartrate-resistant acid phosphatase

TRE thyroid response element

TRH thyrotropin releasing hormone

TRHR thyrotropin-releasing hormone receptor

TRIAC T3 signaling agonist

TSH thyrotropin stimulating hormone

TTF1 transcription termination factor 1

TTF2 transcription termination factor 2

TTR transthyretin

Uen Urocortin

UT assay Uterotrophic bioassay

VMG Validation Management Group

VMG-NA OECD Validation Management Group Non Animal

VTG vitellogenin

WHO World Health Organization

WNT OECD Working Group of National Coordinators of the Test Guidelines

Programme 


\section{EXECUTIVE SUMMARY}

Concern over the potential for environmental chemicals to perturb hormone systems has led to the development and implementation of a number of OECD Test Guidelines for the screening and testing of endocrine disrupting chemicals. Although a number of methodologies have been developed to interrogate reproductive steroids, incorporation of test systems to evaluate disruptors of thyroid hormone signalling pathways has been limited, owing largely to the complexity of the thyroid system. A thyroid scoping effort group (TSEG) comprised of thyroid experts in the VMG NA, VMG-Eco, and the Molecular Screening Group's in vitro Thyroid subgroup was established in 2012, to review the current state of the science on in vitro/ex vivo assays of thyroid disruption. The charge to the TSEG was to bring relevant in vitro thyroid assays to the attention of OECD member countries and provide recommendations for their development/use. In addition, the expert group was to identify in vitro thyroid assays that would provide useful information or fill a gap(s) but would require research and significant optimization prior to use, and determine existence of modes of action within the thyroid system that would not be identified by any assay. This document identifies in vitro or ex vivo assays that could provide screening level (or higher) information on whether a chemical has the potential to modulate thyroid hormone signalling.

Several key biological mechanisms of thyroid system disruption were reviewed for their 'state of readiness as candidates for validation procedures especially with respect to assay reliability, sensitivity, efficiency, and technical criteria, parameters consistent with assay validation in the OECD Test Guideline framework. In the course of the review it was evident that most assays available to probe thyroid disruption had very limited information on the majority of these parameters. Therefore, the primary initial high priority considerations for assay evaluation included four main criteria biological plausibility, extrapolation to humans or broad applicability to across species, availability of resources, and availability of potential reference test chemicals as these were the criteria that remained common across all assays assessed.

Eighteen candidate assay systems were reviewed and categorized for their 'level of readiness' for validation in the short-(A), intermediate (B), or long-term (C). In addition to the level of readiness, assays were further scrutinized for the toxicological relevance of the target site and, chemical space interrogated by the assay. Three assays were identified as the top candidates for consideration for prevalidation in the short term (Category ' $A$ ' level of readiness) including assays for the thyroid hormone synthesis enzyme thyroperoxidase (TPO), and the serum binding/delivery proteins, transthyretin (TTR) and thyroxine binding globulin (TBG). A second block of seven assays was identified by the Expert Panel as in being at a ' $\mathrm{B}$ ' level of readiness and/or as high priority for further research and development. These included assays that probe central regulation at the level of the pituitary and thyroid glands, activation of iodine uptake into the thyroid gland, metabolism of thyroid hormone via deiodination, and development of a combined transporter/TR transactivation assay. In addition, two higher level assays integrating multiple modes of action (MOAs) were flagged as promising as with further development, they could be useful in a screening context. The third set of assays categorized as ' $\mathrm{C}$ ' were not given much further consideration by the TSEG, as although their potential target sites may be of biological and potential toxicological significance, the current assay development status was insufficient for proper assessment at this time. These include central mechanisms of thyroid hormone regulation, local cellular deiodination, and non-nuclear receptor activation. Assays probing some other aspects of thyroid hormone disruption including hepatic metabolism and activation of dimerization partners for thyroid hormone receptor were not reviewed as these topics have been extensively covered in other OECD VMG activities, but could be addressed in a follow-up document. 
Based on this analysis by the TSEG, which has been reviewed and accepted by the VMGNA, recommendations will be made to the WNT to promote these in vitro assays to detect thyroid disruption. Ideally, results of this scoping effort will assist member countries in determining whether the thyroid assays that exist can now be supported for development and optimization/inter-laboratory validation. Finally, where assays probing potential xenobiotic-thyroid target sites were identified as being absent, the research gaps are indicated and can be addressed to ensure that screening programs can confidently cover all avenues of potential thyroid disruption. 


\section{BACKGROUND}

In the 1990's there was an increasing concern that environmental chemicals could adversely impact human health and ecosystems by disrupting hormone systems. Since then an increasing amount of information has accumulated that suggest a wide-variety of environmental contaminants have potential endocrine disruption activity. The OECD initiated a high-priority activity in 1998 to revise existing and to develop new OECD Test Guidelines (TG) for the screening and testing of endocrine disrupting chemicals. A number of potential assays have been developed into OECD Test Guidelines and others are in development. The screens and tests are contained within the "OECD Conceptual Framework for the Screening and Testing of Endocrine Disrupting Chemicals" (CF) which was modified and updated by the Endocrine Disruptor Testing and Assessment (EDTA) Advisory Group (AG) in 2011 (see Annex 1). While the initial focus was on chemicals that altered estrogen and androgen receptor binding, research has expanded to include estrogenic and androgenic signalling pathways, steroidal metabolism, as well as the multiple pathways involved in thyroid hormone homeostasis and signalling.

The OECD's Validation Management Group for Non-Animal Testing (VMG-NA) discussed, in their annual meeting in December 2010, the need for review of existing in vitro and ex vivo assays for identification of modulators of thyroid hormone signalling (referred to as thyroid assays in the document) that could be further developed and/or validated for use by member countries in screening chemicals. In this document the term thyroid hormone signalling does not only refer to thyroid hormone receptor binding and activation but more broadly to the highly regulated system of thyroid hormone affected system influenced by thyroid hormone synthesis, metabolism, transport and excretion. In 2006 a Thyroid Detailed Review Paper (DRP) was developed by OECD (document No. 57) as a joint effort between the three Validation Management Groups (Eco, Mammalian and NonAnimal). It was determined at the time that there were no in vitro thyroid assays recommended for validation. In December 2010, it was proposed that a thyroid scoping group be established, gathering a subgroup of the VMG NA, the Amphibian expert group of the VMG-Eco and the Molecular Screening Group's in vitro Thyroid subgroup, and work together to determine the state of in vitro thyroid assays since the 2006 Thyroid DRP.

The overall goal of the scoping effort is to bring relevant in vitro thyroid assays to the attention of OECD member countries and provide recommendations for their development/use. Relevant assays should include in vitro or ex vivo assays which provide screening level (or higher if possible) information on whether a chemical has the potential to modulate thyroid hormone signalling. Ideally the recommendations provided through this scoping effort would assist member countries in determining whether thyroid assays exist that should be supported for development/optimization/interlaboratory validation.

In addition to identifying in vitro (and ex vivo) thyroid assays that are ready for validation in the short term (i.e., assays that could be useful from a regulatory stand point and which could be recommended for validation), the objectives of the scoping effort are also (i) to identify in vitro thyroid assays that could be developed for potential validation in the longer term (i.e. assays that would provide useful information or fill a gap(s) but would require research and significant optimization in order to determine if they would be suitable for validation) and (ii) to recognize "holes" that are not identified by any existing thyroid assays (i.e. mode of actions within the thyroid system that are not identified by any assay) and the possible reasons for why this endpoint is not covered.

To help in the process the Secretariat developed an initial draft working document that was updated by contribution of an expert group (the Leads) of the Thyroid Scoping Effort Group (TSEG). 
The current document provides background information on the biological substrates these candidate assays were designed to probe and an analysis of their utility for testing purposes (Part 1). Part 2 of the document provides a more detailed technical description of each assay evaluated in Part 1. 


\section{PART ONE:}

EVALUATION OF THE LEVEL OF READINESS OF THE IN VITRO \& EX VIVO THYROID ASSAYS FOR FURTHER DEVELOPMENT, VALIDATION \& INCLUSION IN THE OECD TEST GUIDELINES WORKPLAN 


\section{Introduction}

1. From current knowledge of the thyroid system, which includes for example the level of central regulation in the hypothalamus, at the pituitary gland, or in the thyroid gland itself, it is clear that disruption may occur through multiple and complex biological pathways (Figure 1). For this reason more than one type of in vitro and ex vivo assay will be required to adequately screen chemicals for thyroid disrupting activity, and this document therefore probes several key biological mechanisms of thyroid system disruption, whilst examining and assessing the readiness status of in vitro assays currently available. Such screening tests may be combined with other test results in a battery of assays to detect thyroid disruption, and results can then be evaluated in a weight of evidence approach. Guidance as to where to begin, and in which context, can be obtained using the OECD Endocrine Disruptor Conceptual Framework (OECD, 2012 and see Annex 1), although it should be noted that this is not a testing strategy.

2. The role of metabolism is particularly important when examining thyroid system disruption, and whilst this has been examined in earlier OECD detailed review papers (OECD 2008, Jacobs et al 2008), it is not addressed in this document and could be specifically addressed in a follow-up document.

3. In vitro methods described in this document probe several key biological mechanisms of thyroid system disruption. The key features of thyroid hormone physiology and signalling are depicted in Figure 1.

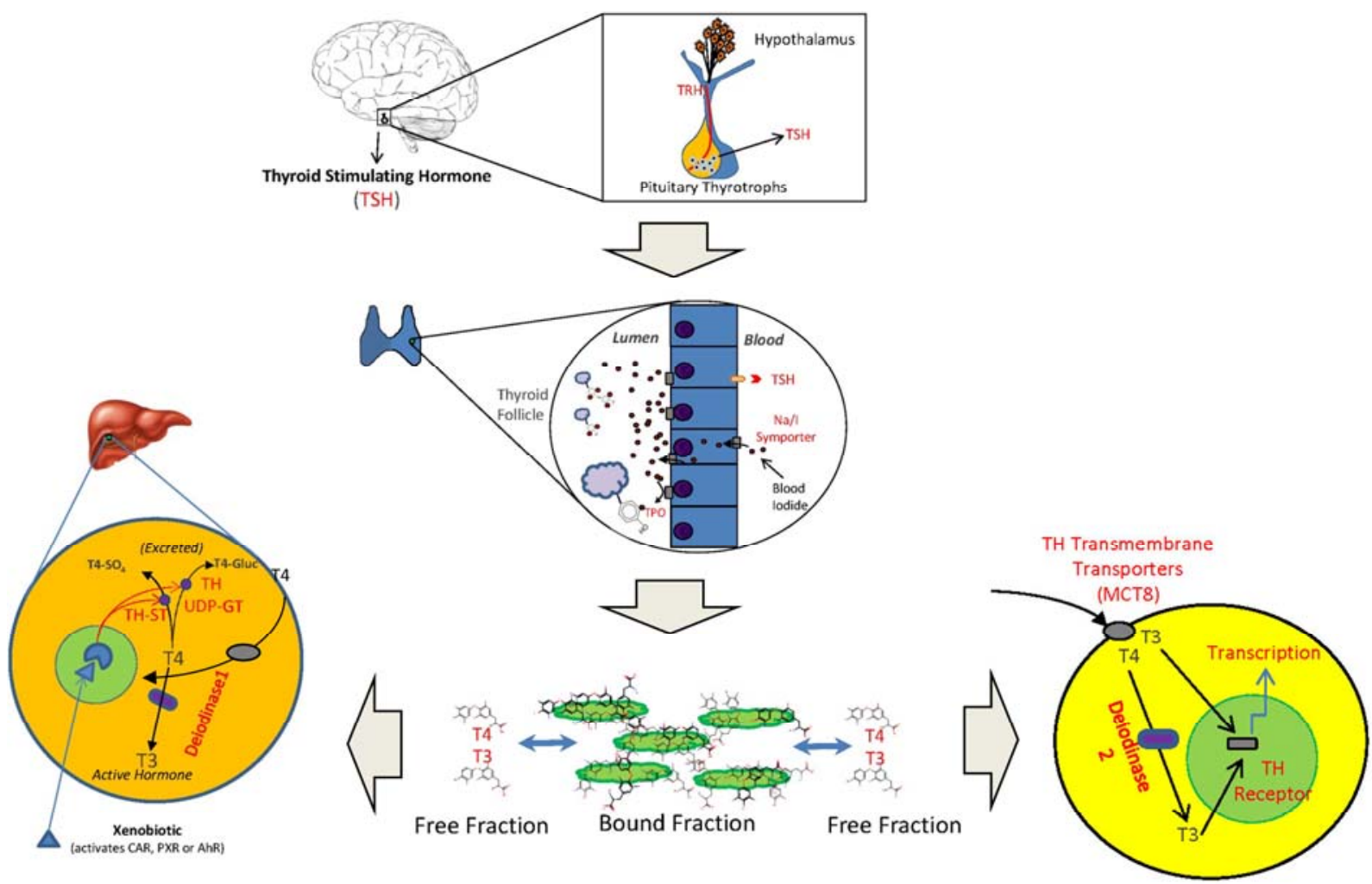

Figure 1. A number of targets exist where chemicals may interact to interfere with thyroid hormone signalling. These can be at the level of central regulation in the hypothalamus, at the pituitary gland, or in the thyroid gland itself. Serum levels of thyroid hormone are maintained within strict physiological ranges through feedback mechanisms. Binding or distributor proteins in the blood limit the availability of active hormone to tissues. Metabolism of hormones in the liver and through peripheral and tissue-specific deiodination pathways also 
modulate the action of thyroid hormones. The figure contains a simplified biosynthetic pathway for thyroid hormones. More detailed figures on the different steps of thyroid hormone synthesis are presented in the introduction to each block of assays.

4. While not explicitly depicted in this figure, it should be noted that all of these steps are intimately integrated and homeostatically regulated by thyroid hormone feedback. All in vitro assays concerning TH function will be placed into context of the Adverse Outcome Pathway (AOP) project on 'Alterations in Thyroid Signalling Systems' that is under development by the US as part of the OECD AOP development programme. In addition to the current work, results of the AOP project will provide the necessary theoretical framework to guide further method development, integration and validation.

5. Interaction of chemicals with the thyroid hormone system is often indicated by apical effects in animal (mainly rodent) studies (e.g., thyroid follicular cell hyperplasia as a consequence of decrease in circulating T4/T3 levels and a resulting increase in TSH). Any effect on circulating thyroid hormones must be of a sufficient duration and magnitude to interfere with normal homeostasis. It is also critical to keep in mind that the timing of the hormone insufficiency in the lifespan of the animal can influence the severity of the insult, the developing foetus and neonate representing a vulnerable window of susceptibility. The most frequently influenced thyroid mode of action (MOA) with the most severe outcomes may also vary across species (e.g., thyroid cancer due to enhanced thyroxine metabolism/clearance is more common in rats than humans). An excellent resource for identifying thyroid toxicants and their MOAs is the data-rich pesticide dossier data. The review of these data (Appendix to EFSA 2013) reveal that the most commonly identified priority indicators are modulation of T3 and or T4 levels, then modulation of TSH and modulation of iodide uptake. In the open published literature, thyroperoxidase (TPO) inhibition, regulation by sodium/iodide symporter (NIS), and metabolic activation are the most common MOAs reported, followed by interference with serum binding proteins and deiodinases. Although modulation of circulating levels of T3 and T4 and TSH / iodide uptake represent the most commonly reported consequence of these chemical actions, such alterations have been linked to physiological and morphological perturbations to thyroid tissues and a mechanism may sometimes be known. Two examples are as follows:

6. In a 28 day rat study exposure to the pesticide Bupirimate $(451 \mathrm{mg} / \mathrm{kg}$ bw/day) was associated with a decrease of T4 levels and an increase in iodine uptake, and at the tissue level, with altered colloid, follicular cell hypertrophy, follicular cell hyperplasia and increased relative thyroid weight were seen. Follicular cell necrosis was observed at $2190 \mathrm{mg} / \mathrm{kg} / \mathrm{bw} / \mathrm{day}$. It appears that blockage of thyroid hormone synthesis in terms of blockage of iodination has been presumed to be an underlying mechanism, leading to decreased T4 hormone output, resulting in thyroid enlargement. .

7. A metabolism related example can be seen with Diethofencarb. For 2 week and 3 month high dose studies of Diethofencarb, decreased circulating T4 but increased TSH levels, and increased relative thyroid weight, while in 2 year studies follicular cell adenoma and carcinoma were observed at $220.30 \mathrm{mg} / \mathrm{kg} / \mathrm{bw} /$ day $\operatorname{LOE}(\mathrm{A}) \mathrm{L}$. The mechanism of action involves the activation of hepatic enzymes (UDP-glucuronyl transferase) metabolising T4 triggering the feedback mechanism of the pituitary gland leading to the promotion of TSH release and a higher serum TSH level(Appendix to EFSA 2013).The developing brain appears not to be capable for compensating for low T4, and thus such modifications may be considered severe if exposure occurs in the developing organism (Sharlin et al 2010, Gilbert and Zoeller, 2010).

8. For the majority of chemicals, however, information on thyroid hormone levels and concrete data on underlying MOA leading to changes in thyroid hormone signalling system are not available. 
As such, consideration of chemical MOA can be instructive in identifying and prioritising assays for inclusion in the OECD Test Guidelines (TG) Programme. Consistent with the AOP framework, knowledge of MOA of substances known to impair thyroid function can assist in identifying key events most frequently influenced and those that cause the most severe outcomes. In addition, a review of thyroid toxicants and their MOAs may serve to identify model substances for use in probing the specificity and sensitivity of any assay for TG validation.

9. In November 2012, experts within the TSEG identified and categorized the existing in vitro and ex vivo assays probing known or potential MOA targets relevant for thyroid endocrine disruption in order to determine which assays would be good candidates for possible inclusion in the OECD Test Guidelines (TG) work plan (OECD public site http://www.oecd.org/env/ehs/testing/Declassified_TGP_Workplan_13\%20June\%202013.pdf).

10. The expert group considered the assays described in Part 2 of this document and agreed on a categorisation scheme based on distinct target sites of potential disruption as described by Murk et al. (2013). The categorisation includes 8 blocks covering all known targets of thyroid disruption except epigenetic changes. The 8 blocks of assay targets are:

- Central regulation

- TH synthesis

- Secretion and transport

- Metabolism and excretion

- Local cellular concentrations

- Cellular responses

- Relevant short term assays integrating multiple MOAs

- Integrative cellular assays

11. The expert group also agreed that within the 8 blocks, the assays can be further categorised into 3 levels depending on their current potential for inclusion in the OECD Test Guidelines work plan:

Level $\mathbf{A}$ - in vitrolex vivo assays that are ready for validation in the short term, i.e. could be proposed for OECD Test Guideline development.

Level B - in vitrolex vivo assays that could be developed for potential validation in the long term, i.e. after an optimization step. In addition, assays which meet criteria for Level A but which screen for modalities of thyroid disruption that can be indirectly detected through other, high priority assays, should be treated as B level of readiness.

Level C - assay gaps (no in vitro/ex vivo assays identified to cover a specific mode of action or disrupting pathways).

12. In order to provide a framework for prioritizing TH assays for further development in the context of the OECD Test Guidelines Programme, a set of ranking parameters was proposed by the OECD Secretariat and presented at the meeting of the TSEG in June 2012. The set of 17 ideal Ranking Parameters was outlined (see Table 1.1 and 1.2) based on the performance standard criteria developed within the VMG-NA for performance test guidelines (e.g. TG 457 and 455) and also Crofton et al. (2011). In the early stages of the analysis the TSEG addressed all of the parameters however, due to a lack of information on most of them, the parameters had to be modified for the purposes of the scoping exercise (see the following section). The ranking parameters as outlined initially could still be 
$\mathrm{ENV/JM/MONO(2014)23}$

useful in the future for analysis, comparison and prioritisation of assays as they are being further developed for inclusion in the TG programme. 
Table 1.1 - Ranking Parameters for Evaluation of the Readiness of Assays for Inclusion in the TG Work plan

\begin{tabular}{|c|c|}
\hline $\begin{array}{c}\text { CATEGORY } 1 \\
\text { Initial High Priority Considerations }\end{array}$ & $\begin{array}{c}\text { CATEGORY } 2 \\
\text { Assay Performance Considerations }\end{array}$ \\
\hline $\begin{array}{l}\text { 1. Biological Plausibility } \\
\text { 2. Extrapolation to humans, or broadly applicable } \\
\text { across vertebrates/phyla } \\
\text { 3. Availability of Resources } \\
\text { 4. Reference Chemicals }\end{array}$ & $\begin{array}{l}\text { 5. Within-laboratory reproducibility } \\
\text { 6. Between-laboratory reproducibility } \\
\text { 7. Assay Variability } \\
\text { 8. Accuracy } \\
\text { 9. Assay Specificity } \\
\text { 10. Assay sensitivity }\end{array}$ \\
\hline $\begin{array}{c}\text { CATEGORY } 3 \\
\text { Technical Capabilities }\end{array}$ & $\begin{array}{c}\text { CATEGORY } 4 \\
\text { Other Practical Considerations }\end{array}$ \\
\hline $\begin{array}{l}\text { 11. Dynamic Range } \\
\text { 12. Concentration test range } \\
\text { 13. Detection/Adjustment of confounding factor } \\
\text { and/or incorrect/ inconclusive measurements } \\
\text { and/or other bias } \\
\text { 14. Response Characterization: }\end{array}$ & $\begin{array}{l}\text { 15. Technological Transferability/Proprietary } \\
\text { elements } \\
\text { 16. Transparency of the method } \\
\text { 17. Documentation of development and utility of } \\
\text { the method. }\end{array}$ \\
\hline
\end{tabular}

13. TSEG further discussed the need to determine the weight of each parameter, and therefore whether or not some parameters should be considered as more important than others and agreed on a ranking of the parameters into four categories:

\section{Category 1: Initial High Priority Considerations}

The parameters in this category are considered of highest priority. In addition, each parameter within this category is considered to have equal weight and all are essential for an acceptable assay, i.e. a poor rating on any one is considered too severely impair the validation or regulatory acceptance of the assay.

\section{Category 2: High Priority Assay Performance Considerations}

These parameters relate to the reliability and efficacy of the assay itself. Generally, these parameters would have high priority in considerations of the potential for development of a protocol for a candidate assay into an OECD Test Guideline. All six parameters within this category are considered to have equal weight.

\section{Category 3: Technical Capabilities}

The parameters in this category also relate to assay performance so the same limitations described for Category 2 parameters apply. However the particular performance issues considered under this category of parameters were identified to be of lesser significance compared to the Category 2 performance issues. 


\section{Category 4: Other Practical Considerations}

This category lists parameters which may present some challenges to validation or broad acceptance of the protocol as an OECD Test Guideline but are not insurmountable. Consequently, these were identified as being of lowest priority. All of the parameters in this list are of equal importance.

More specific guidance on the considerations that should be addressed in the evaluation of each of the 17 parameters is provided below in Table 1.2.

Table 1.2 - Specific Considerations Regarding the Analysis of Individual Parameters

\begin{tabular}{|c|c|}
\hline 1. Biological Plausibility & $\begin{array}{l}\text { The assay should investigate effects on a molecular or biological } \\
\text { process or pathway that can be clearly related to a key initiating event } \\
\text { within a mode of action (MOA) or adverse outcome pathway (AOP). }\end{array}$ \\
\hline $\begin{array}{l}\text { 2. Extrapolation to } \\
\text { humans, or broadly } \\
\text { applicable across } \\
\text { vertebrates/phyla }\end{array}$ & $\begin{array}{l}\text { The assay should use a model system where the response is relevant to } \\
\text { those observed in the human system that, and ideally to a broad } \\
\text { spectrum of other species. }\end{array}$ \\
\hline $\begin{array}{l}\text { 3. Availability of } \\
\text { Resources }\end{array}$ & $\begin{array}{l}\text { The expertise and technology required for the performance of the assay } \\
\text { should be easily acquired or widely available. Ideally, the assay should } \\
\text { not be based on complex, highly expensive, technically challenging } \\
\text { platforms. }\end{array}$ \\
\hline 4. Reference Chemicals & $\begin{array}{l}\text { Reference chemicals are required to demonstrate the accuracy and } \\
\text { performance of the assay (e.g., "the closeness of agreement between a } \\
\text { test method and an acceptance reference value') with respect to the } \\
\text { particular molecular mechanism being probed. Reference chemicals } \\
\text { should be well characterized, with relevant applicability domain } \\
\text { ranges, covering a range of structural diversity, be documented for } \\
\text { their activity and be readily available. They should be representative } \\
\text { of the chemicals classes and potencies, including sufficient number of } \\
\text { negatives, for which the assay is expected to be used. Ideally, known } \\
\text { positives should include non-purpose designed substances, especially } \\
\text { commercial or industrial chemicals. }\end{array}$ \\
\hline $\begin{array}{l}\text { 5. Within-laboratory } \\
\text { reproducibility }\end{array}$ & $\begin{array}{l}\text { A determination of the extent that qualified people within the same } \\
\text { laboratory can successfully replicate results using a specific protocol at } \\
\text { different times. Also referred to as intra-laboratory reproducibility. }\end{array}$ \\
\hline $\begin{array}{l}\text { 6. Between-laboratory } \\
\text { reproducibility }\end{array}$ & $\begin{array}{l}\text { A measure of the extent to which different qualified laboratories, using } \\
\text { the same protocol and testing the same substances, can produce } \\
\text { qualitatively and quantitatively similar results. Inter-laboratory } \\
\text { reproducibility is determined during the pre-validation and validation } \\
\text { processes, and indicates the extent to which a test method can be } \\
\text { successfully transferred between laboratories, also referred to as inter- } \\
\text { laboratory reproducibility. }\end{array}$ \\
\hline 7. Assay Variability & $\begin{array}{l}\text { This parameter demonstrates the degree of variability in the replicates } \\
\text { for an assay as expressed as the standard deviations (SD) or coefficient } \\
\text { of variation (CVs). A response readout with excessively high CV } \\
\text { would be unacceptable }\end{array}$ \\
\hline 8. Accuracy & $\begin{array}{l}\text { This parameter is about assessing if a high level of concordance exists } \\
\text { between } \\
\text { results from the in vitro assay and the result expected for reference }\end{array}$ \\
\hline
\end{tabular}




\begin{tabular}{|c|c|}
\hline & $\begin{array}{l}\text { chemicals for which a value is available from an in vivo assay or } \\
\text { epidemiological data. }\end{array}$ \\
\hline 9. Assay Specificity & $\begin{array}{l}\text { Specificity should be as high as possible. Therefore this parameter } \\
\text { assesses if there is a high rate of true negative results and low rate of } \\
\text { false positive results when testing the accepted reference chemicals. } \\
\text { Ratio of true positive samples over the total number of samples that } \\
\text { should give positive results (true positives + false negatives) }\end{array}$ \\
\hline 10. Assay sensitivity & $\begin{array}{l}\text { Sensitivity should be as high as possible. Therefore this parameter } \\
\text { assesses if there is high rate of true positive results and a low rate of } \\
\text { false negative when testing the accepted reference chemicals. Ratio of } \\
\text { the true negative samples over the total number of samples that give } \\
\text { negative results (true negatives + false positives) }\end{array}$ \\
\hline 11. Dynamic Range & $\begin{array}{l}\text { This parameter considers the degree of change of the response readout } \\
\text { from the assay. It should be sufficiently robust to allow sensitive } \\
\text { detection of increasing dosage of active substances. }\end{array}$ \\
\hline $\begin{array}{l}\text { 12. Concentration test } \\
\text { range }\end{array}$ & $\begin{array}{l}\text { This parameter assesses the degree to which features, inherent in the } \\
\text { model system, may limit the dose range of substance that can be tested } \\
\text { (i.e. need for water solubility, low tolerance for common vehicles, etc.) }\end{array}$ \\
\hline $\begin{array}{l}13 . \\
\text { Detection/Adjustment } \\
\text { of confounding factor } \\
\text { and/or incorrect/ } \\
\text { inconclusive } \\
\text { measurements and/or } \\
\text { other bias }\end{array}$ & $\begin{array}{l}\text { Attributes of the assay that minimize or detect the presence of } \\
\text { confounding factors, and/or reduce the occurrence of inconclusive or } \\
\text { incorrect measurements and other bias, e.g. cell toxicity shall be } \\
\text { assessed in order to reliably demonstrate an antagonistic activity and } \\
\text { avoid confusion due to increase cell toxicity, chemical luminescence or } \\
\text { fluorescence that interferes with response signals. }\end{array}$ \\
\hline $\begin{array}{l}\text { 14. Response } \\
\text { Characterization }\end{array}$ & $\begin{array}{l}\text { The readout of the assay should generate a statistically significant } \\
\text { change when an effective concentration of active substance is tested. }\end{array}$ \\
\hline $\begin{array}{l}\text { 15. Technological } \\
\text { Transferability/ } \\
\text { Proprietary elements }\end{array}$ & $\begin{array}{l}\text { This assesses the degree to which features of the assay model -or } \\
\text { associated technology-are difficult to acquire, or subject to a } \\
\text { monopoly patent, especially if holder of the patent does not support } \\
\text { assay development. Other limitations that might hinder the ability to } \\
\text { acquire the assay components should be assessed. }\end{array}$ \\
\hline $\begin{array}{l}\text { 16. Transparency of the } \\
\text { method }\end{array}$ & $\begin{array}{l}\text { Any data from proof-of-concept or pre-validation exercise should be } \\
\text { available. }\end{array}$ \\
\hline 17. Documentation & $\begin{array}{l}\text { The assay method and optimization process should be described in } \\
\text { sufficient detail to allow effective replication. }\end{array}$ \\
\hline
\end{tabular}

\section{Considerations for the Set of Ranking Parameters as Used in This Document}

14. The parameter tables outlined above were developed to provide guidance on how to select and prioritize assays for further development in the OECD Test Guidelines Programme based on these objective criteria. Upon review of the available assays for thyroid disruption, the TSEG concluded that even for the best characterized among them, insufficient information and a limited number of reference chemicals have been documented. This impeded the ability of TSEG experts to use all of the 'ideal' validation parameters listed in Table 1.2. Therefore, the TSEG agreed to base their primary assessment on the Initial Priority Considerations of Category 1 as described above (Table 1.1) and to consider the others when available under as "Assay Features/Limitations". The availability of documentation for the assays was added as parameter 6 in the new ranking analysis tables, instead of parameter 17 in the initial outline of the ranking parameters. Strict criteria will be developed when 
validation is initiated and conducted for a particular assay. During 2012, the TSEG considered one additional parameter, the suitability of the assay for High-Throughput screening (HTS). However no final conclusion about inclusion of this parameter in the analysis could be reached.

15. The following sections were addressed by the TSEG during 2012-2013 and agreed to at the meeting in November 2012 and the 11 meeting of the VMG-NA in December 2013. The TSEG assessed the readiness of the assays described in Part 2 for inclusion in the TG work plan based primarily on Category 1 parameters as described above, but including others when available. The table below summarises the findings of the evaluation. 
Table 1.3. Summary of the in vitro and ex vivo Thyroid Assays and the Level of Their Readiness for Inclusion in the OECD Test Guidelines (TG) Work plan

\begin{tabular}{|c|c|}
\hline Block of Assays & Readiness Level \\
\hline \multicolumn{2}{|l|}{ [1] Central Regulation (HPT) } \\
\hline TRH production (Hypothalamus) & $\mathrm{C}$ \\
\hline TRH receptor activation (Pituitary) & B \\
\hline TSH receptor activation (Thyroid) & $\mathrm{B}$ \\
\hline \multicolumn{2}{|l|}{ [2] Thyroid Hormone Synthesis } \\
\hline TPO Inhibition & B to $\mathrm{A}$ \\
\hline NIS activation & $\mathrm{B}$ \\
\hline Stem cell derived thyrocytes & not analysed \\
\hline \multicolumn{2}{|l|}{ [3] Secretion and Transport } \\
\hline TTR Binding & $\mathrm{A}$ \\
\hline TBG Binding & $\mathrm{A}$ \\
\hline Transport over placenta \& BBB & not analysed \\
\hline \multicolumn{2}{|l|}{ [4] Metabolism and Excretion } \\
\hline Deiodination Inhibition & B \\
\hline Deiodination up-regulation & B \\
\hline Hepatic nuclear receptor activation & Covered in Metabolism DRP97 \\
\hline Glucuronidation inhibition & Covered in Metabolism DRP97 \\
\hline Glucuronidation \& Sulfation upregulations & Covered in Metabolism DRP97 \\
\hline Sulfation inhibition & Covered in Metabolism DRP97 \\
\hline \multicolumn{2}{|l|}{ [5] Local Cellular Concentrations } \\
\hline TH Membrane Transporters & A \\
\hline TH Membrane Transporter/TR Transactivation & B \\
\hline Local Deiodination & $\mathrm{C}$ \\
\hline \multicolumn{2}{|l|}{ [6] Cellular Responses } \\
\hline Binding to TR LBD & $\mathrm{C}$ to $\mathrm{B}$ \\
\hline Effects of TR Transactivation & $\mathrm{B}$ to $\mathrm{A}$ \\
\hline Co Regulator Interaction & Not analysed \\
\hline Activation dimerization partners TR (RXR) & Covered in DRP 178, DRP 97 \\
\hline Non-Nuclear TR mediated responses & Not analysed \\
\hline \multicolumn{2}{|c|}{ [7] Relevant Short-Term Assays Integrating Multiple MOAs } \\
\hline Zebra fish embryo & $\mathrm{B}$ \\
\hline Sea Urchin Metamorphosis assay & not analysed \\
\hline GFP-Xenopus Embryo & TG under development in Project 2.39 \\
\hline Short term Xenopus Metamorphosis assay & not analysed \\
\hline Thyroid gland explant culture & $\mathrm{B}$ \\
\hline \multicolumn{2}{|l|}{ [8] Integrative Cellular Assays } \\
\hline T-Screen (TR induced proliferation assay & $\mathrm{C}$ \\
\hline Human neural progenitor cell & $\mathrm{C}$ \\
\hline TSH induced proliferation assay & not analysed \\
\hline
\end{tabular}




\section{EVALUATION OF BLOCK \#1 ASSAYS - CENTRAL REGULATION (HPT)}

16. This block concerns effects directly on the synthesis/release of hypothalamic thyroid releasing hormone (TRH), its delivery and action on pituitary thyrotrophs, and the synthesis/release of thyroid stimulating hormone (TSH) (see Figure 2). Despite the fact that the master regulator of the HPT axis, TRH is an easily assayed tri-peptide, setting up a biologically relevant in vitro system to assess effects of potential disruptors of T3 regulation of Trh transcription and TRH production is far from straightforward. The main problem is obtaining an in vitro system that replays a) the TR $\beta$ specific transcriptional repression of Trh transcription, b) the complex enzymatic processing of the preprohormone to active TRH, and c) the controlled process of active TRH secretion at the neuronal terminals in close association with the glial cells. Similar arguments apply to TRH receptor activation. Notably, TRH activation of the TRHR1 on thyrotropes activates first the release of ready available TSH and then the synthesis of the two subunits, the $\alpha$ subunit common to all glycoproteins of the pituitary ( $\alpha \mathrm{GSU})$ and the TSH specific $\beta$ subunit, $\beta$ TSH. TRHR-1 activation in thyrotropes leads to activation of the phospholipase $\mathrm{C}$ dependent signal transduction that includes $\mathrm{Ca}++$ mobilisation and PKC activation. Finding a cell line that faithfully reproduces these three lines of action has not been satisfactorily demonstrated. The TSH receptor activation assay is further advanced. In addition to the lack of an appropriate in vitro model, validation of any assay based on these MOAs would be hindered by the lack of substances known to impair either TRH or TSH release in vivo.

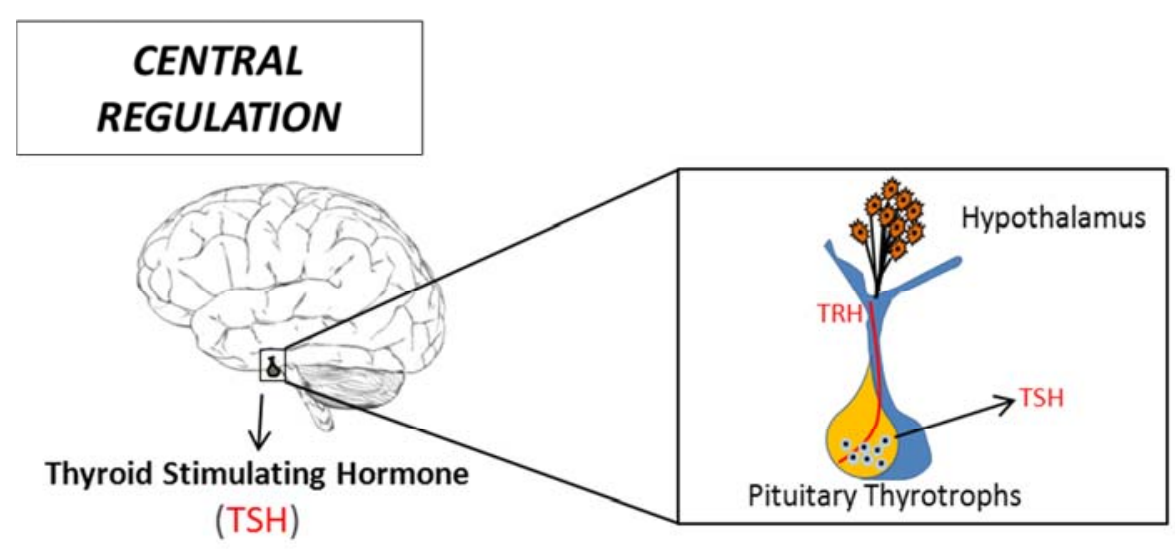

Figure 2: Hypothalamic control of release of thyroid stimulating hormone by the pituitary gland. Thyroid releasing hormone-secreting neurons with cell bodies located in the paraventricular nucleus of the hypothalamus. Stimulation of these cells with various signals induces the secretion of TRH into the hypothalamic pituitary portal systems which drains into capillary beds that perfuse thyrotrophes in the anterior pituitary. TRH stimulation of thyrotrophes induces the expression and secretion of the glycoprotein Thyroid Stimulating Hormone (TSH). There are currently no xenobiotics known which directly alter TRH secretion/action or TSH release.

Conclusion: The block of assays targeting central HPT regulation assessment is determined as being at a low level of readiness (level C and B) for inclusion in the TG programme.

\begin{tabular}{|c|c|c|}
\hline $\begin{array}{c}\text { TRH production } \\
\text { (Hypothalamus) }\end{array}$ & $\begin{array}{c}\text { TRH receptor } \\
\text { activation (Pituitary) }\end{array}$ & $\begin{array}{c}\text { TSH receptor activation } \\
\text { (Thyroid) }\end{array}$ \\
\hline C & B & B \\
\hline
\end{tabular}




\section{Hypothalamic Thyrotropin-Releasing Hormone (TRH) Production/Release}

17. Overview: Thyroid hormone levels are kept within physiological ranges through hypothalamo-pituitary neuro-endocrine feedback loops (Silva 1995). Increased T3 represses transcription of hypothalamic thyrotropin-releasing hormone (TRH), the master regulator of the hypothalamo-pituitary/thyroid (HPT) axis (Lezoualch et al. 1992). In turn, decreased T3 output reduces metabolism and energy usage (Fekete and Lechan 2007).

18. Hypothalamic TRH neurons integrate numerous metabolic, endocrine and neuronal signals (Hollenberg 2008). T3-responsive TRH neurons in the paraventricular nucleus (PVN) of the hypothalamus express all the functional thyroid hormone nuclear receptors (TRs) and a key membrane receptor involved in energy homeostasis, the melanocortin receptor Mc4r, a membrane receptor integral to central leptin/melanocortin signalling (Wikberg and Mutulis 2008). Leptin is a major satiety hormone and regulates energy homeostasis through food intake, energy partition and thermogenesis (Wikberg and Mutulis 2008). Prolactin and dopamine also influence central regulation of thyroid hormone signalling system via TRH production and action and could be potential targets for assay development (Joseph-Bravo et al. 1998; Uribe et al. 2009). A more recent review that covers many of the multiple influences of different neuropeptides on the TRH neuron is provided by Fekete and Lechan, 2013.

19. Transcriptional regulation of TRH is highly cell specific. Brain regions other than the PVN express TRH (Decherf et al.2010b), and in the periphery some cells also express the preprothyrotropin gene and produce the tripeptide TRH (i.e., pancreatic $\beta$ cells). However, only in the PVN neurons is the preprothyrotropin gene and TRH production are specifically down regulated by T3. This negative regulation requires a TR $\beta$ isoform (Guissouma. 1998) and presence of co-modulator factors, such as N-CoR (Cohen et al. 1998), see also the recent review from Fekete and Lechan 2013.

20. Conclusions: Although no validated in vitro assay replicates this complex neuron-specific regulation, transcriptional regulation has been observed in a monkey kidney cell line, CV-1 cells, (Cohen et al. 1998; Hollenberg et al. 1995), a human placental cell line (Flynn et al. 1994), and in primary cultures of chick hypothalamic neurons (Lezoualch et al. 1992). 


\begin{tabular}{|c|c|}
\hline \multicolumn{2}{|c|}{$\begin{array}{l}\text { HYPOTHALAMIC THYROTROPIC RELEASING HORMONE PRODUCTION AND } \\
\text { RELEASE. }\end{array}$} \\
\hline 1. Biological Plausibility & $\begin{array}{l}\text { Moderate: Production of the tripeptide TRH implicates a complex } \\
\text { maturation process that is limited to a very specialised group of } \\
\text { neurons in the paraventricular nucleus of the hypothalamus. Its } \\
\text { production and release are is critical for regulation of the thyroid } \\
\text { hormone pathway. Physiological regulation of TRH involves } \\
\text { repression by T3 at the transcriptional level through specific TRs, } \\
\text { TRb1 and TRb2. As yet no in vitro systems recapitulate the complex } \\
\text { physiology of Trh transcription, TRH maturation and release. }\end{array}$ \\
\hline $\begin{array}{l}\text { 2. Extrapolation to } \\
\text { humans, applicable } \\
\text { across vertebrates/phyla }\end{array}$ & $\begin{array}{l}\text { Strong - similar physiology across vertebrates, though in fish and } \\
\text { amphibians CRH also has a strong stimulatory action on TSH, so } \\
\text { examination of CRH is also relevant to understanding hypothalamic } \\
\text { control of TSH and thyroid hormone production in fish and amphibian }\end{array}$ \\
\hline $\begin{array}{l}\text { 3. Av } \\
\text { Reso }\end{array}$ & $\begin{array}{l}\text { Weak - Only TRH antibody is available, but no in vitroo method to } \\
\text { test physiologically relevant production or release. }\end{array}$ \\
\hline 4. Reference Chemicals & $\begin{array}{l}\text { Weak - No chemicals have been tested for TRH production. Though } \\
\text { TBT and TBBPA disrupt Trh transcription in vivo. }\end{array}$ \\
\hline $\begin{array}{l}\text { 5. Assay } \\
\text { Features/Limitations }\end{array}$ & $\begin{array}{l}\text { TRH production evaluated in isolation of the other components of the } \\
\text { HPT central regulatory systems is likely of limited utility. } \\
\text { Commercially available TRH antibody, but not in vitro system to test } \\
\text { interference with environmental contaminants.. Potential for cross- } \\
\text { reactivity with TRH antibodies. }\end{array}$ \\
\hline 6. Documentation & Wang and $\mathrm{Xu}, 2008$; Decherf et al., 2010a and 2010b. \\
\hline
\end{tabular}




\section{Pituitary - Thyrotropin-Releasing Hormone (TRH) Receptor Activation Assay}

21. Overview: Thyrotropin-releasing hormone (TRH) is secreted from the terminals of TRH containing neurons and released into the median eminence from whence it reaches the pituitary gland. Thyrotrophs in the anterior pituitary express the TRH receptor, TRHR1. TRHR1 function is well characterised, notably rapidly desensitizing (Hinkle et al., 2012), a fact that should be taken into account in all assay development. Thyrotrophs produce thyrotropin or thyroid stimulating hormone (TSH). TRH stimulation of TRHR1 leads to activation of phospholipase $\mathrm{C}, \mathrm{Ca}++$ mobilization and activation of PKC (Abe et al. 2004). TRH activates not only the secretion of TSH but also the transcription of TSH $\beta$ and $\alpha$-glycoprotein ( $\alpha \mathrm{GSU})$ subunit genes. TSH $\beta$ subunit expression is maintained by two transcription factors, Pit 1 and GATA2, and is negatively regulated by thyroid hormone (T3) (Ohba et al., 2011). A well characterised anterior pituitary cell line exists that expresses TRHR1 is the GH3 cell line (Hinkle et al. 1980), though, as their name suggests, most of the GH3 cells lines are derived from prolactin or growth hormone secreting tumours. This assay has never been applied to assess endocrine disruptors. No reference chemicals that disrupt this mechanism are available to develop this assay.

\begin{tabular}{|l|l|}
\hline TRH-R ACTIVATION OF PITUITARY THYROTROPHS \\
\hline 1. Biological Plausibility & $\begin{array}{l}\text { Moderate: The mechanisms that might be assessed are critically } \\
\text { important for thyroid hormone physiology. TRH stimulation or TRH- } \\
\text { R-mediated activation and TSHb transcription. }\end{array}$ \\
\hline $\begin{array}{l}\text { 2. Extrapolation to } \\
\text { humans, broadly } \\
\text { applicable across } \\
\text { vertebrates/phyla }\end{array}$ & Strong. - Similar physiology across the vertebrates. \\
\hline $\begin{array}{l}\text { 3. Availability of } \\
\text { Resources }\end{array}$ & $\begin{array}{l}\text { Strong. A commercial assay is available for TRH-R activation using a } \\
\text { recombinant TRH Receptor in stable cell line (MILLIPORE). }\end{array}$ \\
\hline 4. Reference Chemicals & Weak. No reference chemicals are available. \\
\hline $\begin{array}{l}\text { 5. Assay Features } \\
\text { /Limitations }\end{array}$ & $\begin{array}{l}\text { Human recombinant TRH receptor activation assay with calcium flux } \\
\text { readout in stable cell line. Research-based assay, no EDCs have been } \\
\text { assessed. Does not take into account desensitization due to receptor } \\
\text { internalization. }\end{array}$ \\
\hline 6. Documentation & $\begin{array}{l}\text { Hinkle et al., 1980. No literature citations using primary thyrotrophs or } \\
\text { GH3 cells for endocrine disruption of TRH-R action were found }\end{array}$ \\
\hline
\end{tabular}




\section{TSH Receptor Activation Assay}

22. Overview: The TSH receptor is expressed on the basal membrane of thyroid follicle cells. Three assays have followed disruption of TSH-R action or its modification by pharmaceutical agents. In all cases the assays used TSH-R transfected into cell lines. The first one was Santini et al who used Chinese hamster ovary cells (CHO) and tested the effects of a limited number of pesticides on TSH induced cAMP production (Santiniet al. 2003). One of the first groups to use this sort of cell line was a Swedish group who compared stable transfection of the TSH-R in the CHO line and the NIH-TS-R line. The CHO line had the advantage of not showing desensitization to a second TSH stimulation (Heldin et al.1994). Another group used the same cell line (and two other cell lines namely COS-7 and HeLa cells transfected with TSH-R) to assess the effects of the pesticide, DDT on TSH-R internalization to assess the effects of the pesticide, DDT on TSH-R internalization (Picchietti et al. 2009). Later Gershengorn's group used HEK-EM 293 cells stably expressing wild-type TSHRs (Neumann et al. 2010) to evaluate actions of potential synthetic TSH antagonists, again using TSHdependent cAMP production as a readout.

\begin{tabular}{|l|l|}
\hline TSH RECEPTOR MEDIATED ACTIVATION OF CAMP PRODUCTION IN CHO CELLS. \\
\hline 1. Biological Plausibility & $\begin{array}{l}\text { Moderate: The mechanisms are critically important for thyroid } \\
\text { hormone physiology. This assay uses TSH-dependent production of } \\
\text { cAMP. }\end{array}$ \\
\hline $\begin{array}{l}\text { 2. Extrapolation to } \\
\text { humans, or broadly } \\
\text { applicable across } \\
\text { vertebrates/phyla }\end{array}$ & $\begin{array}{l}\text { Moderate - similar physiology across the vertebrates. However } \\
\text { Chinese hamster ovary cells (CHO) transfected with the TSH-R have } \\
\text { to be established. }\end{array}$ \\
\hline $\begin{array}{l}\text { 3. Availability of } \\
\text { Resources }\end{array}$ & $\begin{array}{l}\text { Weak. Academic laboratories (Lechan in Boston and Csaba Fekete in } \\
\text { Budapest) are known to be setting up these assays }\end{array}$ \\
\hline 4. Reference Chemicals & Weak DDT, Arochlor 1254 \\
\hline $\begin{array}{l}\text { 5. Assay Features/ } \\
\text { Limitations }\end{array}$ & $\begin{array}{l}\text { The mechanisms are critically important for thyroid hormone } \\
\text { physiology and need to be assessed. Assay has only been run in a } \\
\text { research setting and is currently not available in any laboratory. }\end{array}$ \\
\hline 6. Documentation & Hinkle et al., 1980 \\
\hline
\end{tabular}




\section{EVALUATION OF BLOCK \#2 ASSAYS - THYROID HORMONE SYNTHESIS}

23. The block of assays targeting assessment of thyroid hormone synthesis (outlined in Figure 3) encompasses three types of assays to evaluate thyroperoxidase activity (TPO), activation of the sodium iodide symporter (NIS), and functional assessment of stem cell-derived thyrocytes. Several TPO and NIS assays are described. Stem cell-derived thyrocytes function assays have not yet been analysed. The analysis of the TPO assays indicates that one of them is at an intermediate level (B/A) of readiness for inclusion in the TG programme. The analysis of the NIS assays indicates that they are overall at level B of readiness for further development.

\begin{tabular}{|c|c|c|}
\hline TPO inhibition & NIS activation & $\begin{array}{c}\text { Stem cell-derived } \\
\text { thyrocytes }\end{array}$ \\
\hline B to A & B & Not analysed \\
\hline
\end{tabular}

\section{THYROID HORMONE SYNTHESIS}

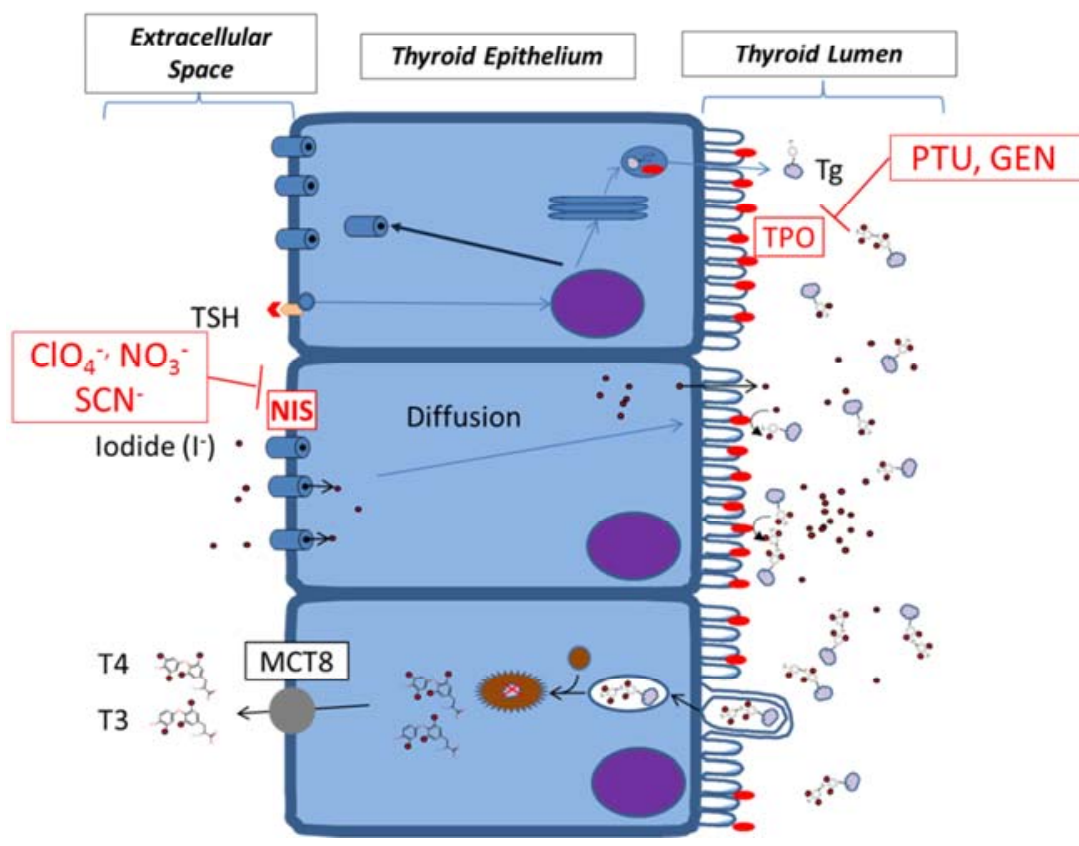

Figure 3: Key molecular initiating events that occur within the thyroid gland. TSH action on thyroid epithelial cells results in increased expression of sodium iodide symporter (NIS), thyroglobulin (Tg) and thyroperoxidase enzyme (TPO) among other effects. NIS is a transmembrane ion transporter molecule that is located on epithelial cell surface adjacent to the extracellular space. Iodide ions are actively taken up from tissue fluid into cells through NIS action. NIS can be inhibited by

xenobiotics such as perchlorate $\left(\mathrm{ClO}_{4}^{-}\right)$, nitrate $\left(\mathrm{NO}_{3}^{-}\right)$or thiocyanate $(\mathrm{SCN})$. Iodide is transported into the follicle lumen where it is conjugated with tyrosine residues on Tg protein through the action of TPO. Iodinated phenols are in turn, ether-linked to adjacent tyrosines also through the action of TPO. TPO activity can be inhibited by several substances including genistein (GEN) and propylthiouracil (PTU). TSH stimulation induces the uptake of Iodinated Tg by epithelial cells through pinocytosis. This is, in turn, degraded by lysosomal enzymes to release T4 into serum and a much lesser amount of T3. THs are released from the thyroid epithelium through the action of TH transporter molecules such as monocarboxylase transporter 8 (MCT8). 


\section{Thyroperoxidase (TPO) Function Assays}

24. Overview: Thyroperoxidase (TPO) is a heme-containing apical membrane protein within the follicular lumen of thyrocytes that acts as the enzymatic catalyst for thyroid hormone synthesis. TPO catalyses several reactions, including the oxidation of iodide, nonspecific iodination of tyrosyl residues of thyroglobulin (Tg), and the coupling of iodotyrosyls to produce Tg-bound triiodothyronine (T3) and tetraiodothyronine (T4) (Divi et al., 1994; Kessler et al., 2008; Ruf et al., 2006; Taurog et al., 1996). From a clinical perspective, TPO represents a predominant autoantigen in autoimmune thyroid diseases (Czarnocka, 2011; Kaufman et al., 1989; McLachlan et al., 2007). From a toxicological perspective, chemical inhibition of TPO enzymatic activity is a well-documented molecular-initiating event in an adverse outcome pathway for thyroid hormone disruption in rodent models (Crofton, 2008; DeVito et al., 1999; Doerge et al., 2002a; Hurley, 1998; Murk et al., 2013; Zoeller et al., 2005). Treatment of hyperthyroidism with medications including methimazole (MMI) and 6-propylthiouracil (PTU) has solidified a causative relationship between TPO inhibition, decreased thyroid hormone synthesis, and subsequently decreased systemic thyroid hormone concentrations in humans and animals (Cooper, 2005; Emiliano et al., 2010; Hosoya, 1963; Sugawara et al., 1999; Trepanier, 2006). Importantly, the critical function of TPO is conserved across taxonomic class, as chemicals may inhibit TPO activity and result in decreased serum and/or tissue thyroid hormone concentrations in mammalian, amphibian, and avian species (Coady et al., 2010; Grommen et al., 2011; Rosebrough et al., 2006; Tietge et al., 2012). The evidence implicating TPO as a necessary enzymatic component of thyroid hormone synthesis across species underscores the saliency of developing screening assays to detect TPO-inhibiting compounds, and ultimately for the development of a system biology predictive tool for thyroid disruption.

25. Myriad chemicals across structural classes are known to inhibit TPO (i.e., MMI, potassium cyanide, sodium azide, 3-amino-1,2,4-triazole (amitrole), thiouracil, PTU, p-aminobenzoate, potassium thiocyanate, potassium perchlorate, sodium fluoride, thiourea, daidzein, genistein, ethylene thiourea, $N, N, N^{\prime}, N^{\prime}$-tetramethylthiourea, resorcinols, sulfamethazine, leucomalachite green, benzophenone-2, 2-mercaptobenzothiazole, 4-propoxyphenol, 4-nonylphenol).

26. These chemical-inhibitors of TPO-catalyzed TH synthesis have largely been identified with models that have relied on upon the assertion that TPO activity is conserved across species. Porcine TPO (pTPO), derived from thyroid follicles, microsomes, or partially-purified protein fractions has been used frequently in either the guaiacol or iodide oxidation assays or the tyrosine iodination assay(Divi et al., 1997; Divi et al., 1994; Doerge et al., 2002b; Sugawara et al., 1999; Freyberger \& Ahr, 2006). A common substitute for pTPO has been bovine lactoperoxidase (bLPO) (Divi et al., 1994; Doerge et al., 1989; Taurog et al., 1996;); due to high conservation of residues within the catalytic domain of the superfamily of animal peroxidases and the homology of myeloperoxidase, LPO and thyroperoxidase in particular (Furtmuller et al., 2006), substitutions for TPO have produced plausible results in peroxidation assays. However, there are no systematic investigations demonstrating comparable sensitivity of LPO to inhibition by known chemical classes of TPO inhibitors.

27. Although the assertion of concordance of TPO activity across species few studies have directly evaluated qualitative and quantitative differences in TPO activity across species. Takayama et al. (1986) compared the sensitivity of monkey and rat TPO in the guaiacol assay and reported a 51times and $>455$-times higher sensitivity of rat TPO for PTU and the sulfonamide, sulfamonomethoxin. Recentlyan evaluation of pTPO and rat TPO using the guaiacol oxidation assay demonstrated $100 \%$ qualitative concordance with only minor variability in quantitative results between species for a 12 chemical training set (Paul et al., 2013). Porcine TPO has also been used to accurately model inhibition of TPO activity by 2-mercaptobenzothiazole observed in a whole animal Xenopus laevis 
model (Tietge et al., 2012). However, while the use of porcine tissue for TPO assays seems to give qualitatively the same results as obtained with rat tissue, there were differences in the relative potency for TPO inhibition that could result in some compounds being missed if only porcine tissue is used to screen chemicals. A recent report suggested that rat TPO may be more responsive than human TPO to xenobiotic inhibitors MMI and PTU (Vickers et al., 2012), but assessment with a larger chemical set would be necessary to evaluate this hypothesis.

28. One potentially related endpoint that has not been considered for medium- or highthroughput assay development is dependence of TPO activity on the co-localized membrane partner and catalytic generator of $\mathrm{H}_{2} \mathrm{O}_{2}$, dual oxidase 2 (DUOX2) (Fortunato et al., 2010). A separate consideration of DUOX2 and potential inhibitors is required to determine the necessity to develop screening assays for DUOX2 inhibition, or if inclusion of DUOX2 with TPO in a downstream test with greater biological complexity would be sufficient.

29. Overall, the current published assays involve either UV absorbance (where compounds can interfere with the assay) or use HPLC to separate the 3-iodo and 3,5-dioodo metabolites. However it is also possible to utilise UPLC-MS-MS detection for both these metabolites. This not only gives specificity of metabolite identification but also gives good sensitivity when using small amounts of tissue (e.g. rat thyroid gland microsomal fractions (Brian G Lake unpublished data).

30. Conclusion: Screening assays for inhibition of TPO are clearly necessary in order to assess this relevant target of a diverse set of environmentally-relevant thyroid-disrupting chemicals. There is an available assay, the AUR-TPO inhibition assay, which may be suitable for a medium- or highthroughput screening application. Development of additional orthogonal assays or assays that do not use animal tissue may be important for increasing the chemical space that can be tested with this assay technology and confidence in the assay results. 
RANKING PARAMETER ANALYSIS FOR TPO ASSAYS

\begin{tabular}{|l|l|}
\hline AMPLEX ULTRARED® & THYROPEROXIDASE INHIBITION ASSAY - AUR-TPO \\
\hline 1. Biological Plausibility & $\begin{array}{l}\text { Strong. TPO catalytic activity is essential for thyroid hormone } \\
\text { synthesis, for the coupling of monoiodotyrosine (MIT) and/or } \\
\text { diiodothyronine (DIT) on thyroglobulin within the follicular lumen of } \\
\text { thyrocytes. }\end{array}$ \\
\hline $\begin{array}{l}\text { 2. Extrapolation to } \\
\text { humans, or broadly } \\
\text { applicable across } \\
\text { vertebrates/phyla }\end{array}$ & $\begin{array}{l}\text { Strong. Complete qualitative concordance, and similar quantitative } \\
\text { results, for rat and porcine TPO (pTPO). Previous work with pTPO } \\
\text { and lactoperoxidase has been confirmed with whole animal rat and } \\
\text { amphibian models. }\end{array}$ \\
\hline $\begin{array}{l}\text { 3. Availability of } \\
\text { Resources }\end{array}$ & $\begin{array}{l}\text { Moderate. Source of TPO or similar enzyme may be a barrier. Thyroid } \\
\text { glands as TPO source can be difficult to obtain by commercial or } \\
\text { necropsy methods. Hog thyroids are large and more readily accessible } \\
\text { from slaughterhouses. }\end{array}$ \\
\hline 4. Reference Chemicals & $\begin{array}{l}\text { Strong. Many TPO-inhibiting chemicals available to include in assay } \\
\text { training sets. These include pharmaceuticals, to pesticides, to } \\
\text { industrial-use chemicals. }\end{array}$ \\
\hline Medium to high throughput established. Highly relevant target site. CV \\
5. Assay Features/ \\
Limitations
\end{tabular}

GUAIACOL/IODIDE OXIDATION / TYROSINE IODINATION THYROPEROXIDASE INHIBITION ASSAYS

1. Biological Plausibility

Strong. TPO catalytic activity is essential for thyroid hormone synthesis. Iodide is the physiological substrate for TPO-catalysed iodination. These assays reflect key events in iodination, i.e., the oxidation of iodide and the iodination of tyrosine. Guaiacol oxidation rather measures TPO peroxidative activity as needed for the coupling reaction.

2. Extrapolation to humans, or broadly applicable across vertebrates/phyla Strong. These assays have been successfully applied to rat, monkey, porcine, and in some cases human recombinant and human goiter TPO. In the future, assay systems could be used with recombinant human TPO or LPO.

Moderate. Source of TPO or similar enzyme may be a barrier. Thyroid

3. Availability of Resources

4. Reference Chemicals

5. Assay Features/ Limitations glands as TPO source can be difficult to obtain by commercial or necropsy methods. Hog thyroids are large and more readily accessible (see above). If chromatography is used (tyrosine iodination) an HPLC is necessary.

Strong. Many TPO-inhibiting chemicals available to include in assay training sets. These include pharmaceuticals, to pesticides, to industrial-use chemicals.

Highly relevant target site. Several protocols with different assay conditions have been published. Cell-free assay so cytotoxicity is not 


\begin{tabular}{|l|l|}
\hline & $\begin{array}{l}\text { limiting. Low throughput. Source of TPO may be rate limiting. } \\
\text { Compounds known to readily react with quinones such as thiols may } \\
\text { trap the assay oxidation product (guaiacol assay) and mask peroxidase } \\
\text { activity. Possible that coloured chemicals could interfere with the } \\
\text { accurate quantification of colour formation. }\end{array}$ \\
\hline 6. Documentation & $\begin{array}{l}\text { Vickers et al., 2012; Paul et al., 2013; Tietge et al., 2012; Doerge et al., } \\
\text { 2002b; Freyberger and Ahr, 2006 }\end{array}$ \\
\hline
\end{tabular}




\section{Sodium Iodide Symporter (NIS) Activity Assays}

31. Overview: Active uptake of iodide by thyroid follicular cell in the thyroid gland is essential for TH synthesis. This is accomplished by the sodium-iodide symportor (NIS). Competitive inhibition of NIS-mediated iodide uptake by specific anions blocks not only thyroidal iodide uptake and impairs TH synthesis (Wolff, 1998). In humans, mutations in the NIS protein are associated with congenital iodide transport defect, a condition characterized by low iodide uptake, hypothyroidism and goitre (Bizhanova and Kopp, 2009). The classic assay to test the ability of a chemical to interfere with NISmediated iodide uptake is based on the measurement of radioiodine $\left({ }^{125} \mathrm{I}\right)$ uptake in NIS-expressing thyroid (FRTL5) cells (Atterwill and Fowler, 1990; Schmutzler et al., 2007b).

32. A fully automated radioiodine uptake assay was developed for rapid and quantitative screening of test chemicals in a 96-well format using HEK293 cells transfected with human NIS (Lecat-Guillet et al., 2007, 2008; Lindenthal et al., 2009). This method has been used to screen a chemical library of 17,020 structures (Lecat-Guillet et al., 2008). A nonradioactive iodide uptake assay was recently developed using FRLT5 cells (Waltz et al., 2010). A fluorescent assay for cellular iodide uptake was also recently developed. Substances known to interfere with iodide transport via the NIS transporter that might be considered as possible reference chemicals include perchlorate and thiocyanate.

33. Conclusion: The development of screening assays for NIS inhibition is clearly necessary in order to assess a relevant target of environmentally-relevant thyroid-disrupting chemicals. Both radioactive and fluorescence based thyroid and transiently transfected cell based assays are available and have been used to screen environmental chemicals. Analysis of the group of NIS assays indicates that they are at an intermediate level (level C-B) of readiness for validation in the short term and could be proposed for OECD TG development. 
RANKING PARAMETER ANALYSIS FOR NIS ASSAYS

\begin{tabular}{|l|l|}
\hline $\begin{array}{l}\text { SODIUM/IODIDE UPTAKE ASSAY: RADIOACTIVE IODIDE IN TRANSIENTLY } \\
\text { TRANSFECTED FRTL-5 CELLS }\end{array}$ \\
\hline $\begin{array}{l}\text { 1. Biological Plausibility } \\
\begin{array}{l}\text { 2. Extrapolation to } \\
\text { humans, or broadly } \\
\text { applicable across } \\
\text { vertebrates/phyla }\end{array}\end{array}$ & $\begin{array}{l}\text { Strong. Iodine is essential for thyroid hormone synthesis. The sodium- } \\
\text { iodide symporter (NIS) transports iodine into the thyroid gland. }\end{array}$ \\
\hline $\begin{array}{l}\text { 3. Availability of } \\
\text { Resources }\end{array}$ & Strong. Materials readily available but uses radioactivity \\
\hline 4. Reference Chemicals & Weak. No endocrine disrupting chemicals tested \\
\hline $\begin{array}{l}\text { 5. Assay Features/ } \\
\text { Limitations. }\end{array}$ & $\begin{array}{l}\text { Only currently used in research setting. Transient transfection. No } \\
\text { environmental toxicants tested. High variability. Uses radioactivity. }\end{array}$ \\
\hline 6. Documentation & Atterwill and Fowler, 1990; Schmutzler et al., 2007 \\
\hline
\end{tabular}

\begin{tabular}{|c|c|}
\hline \multicolumn{2}{|c|}{ 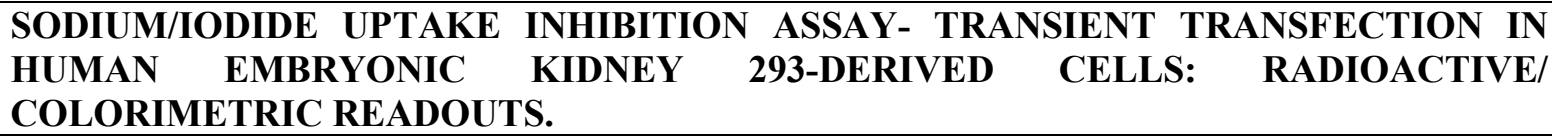 } \\
\hline 1. Biological Plausibility & $\begin{array}{l}\text { Strong. Iodine is essential for thyroid hormone synthesis. The sodium- } \\
\text { iodide symporter (NIS) transports iodine into the thyroid gland. }\end{array}$ \\
\hline $\begin{array}{l}\text { 2. Extrapolation to } \\
\text { humans, or broadly } \\
\text { applicable across } \\
\text { vertebrates/phyla }\end{array}$ & $\begin{array}{l}\text { Strong. Iodine uptake via NIS is well conserved across species. } \\
\text { Human cells used with endogenous NIS }\end{array}$ \\
\hline $\begin{array}{l}\text { 3. Availability of } \\
\text { Resources }\end{array}$ & Strong. For colorimetric method, weaker for radioactivity method \\
\hline 4. Reference Chemicals & $\begin{array}{l}\text { Low. Radioactivity method has been used to screen a chemical library } \\
\text { of } 17,020 \text { structures, but only } 10 \text { flagged as positive }\end{array}$ \\
\hline $\begin{array}{l}\text { 5. Assay } \\
\text { Limitations }\end{array}$ & $\begin{array}{l}\text { Large chemical library screened but limited detection. Nanomolar } \\
\text { concentrations of test substance detected when positive. Any cell-based } \\
\text { NIS assay subject to bias induced quenching of radioactive signal by } \\
\text { some chemicals; isotopic dilution due to free iodide in the samples; } \\
\text { alteration in the membrane status; cell toxicity }\end{array}$ \\
\hline 6. Documentation & Lecat-Guillet et al., 2007, 2008; Lindenthal et al., 2009 \\
\hline
\end{tabular}




\begin{tabular}{|l|l|}
\hline $\begin{array}{l}\text { NON RADIOACTIVE } \\
\text { KOLTHOFF REACTION AND USING FRTL5 CELLS }\end{array}$ \\
\hline \begin{tabular}{l} 
1. Biological Plausibility \\
$\begin{array}{l}\text { Strong. Iodine is essential for thyroid hormone synthesis. The sodium- } \\
\text { iodide symporter (NIS) transports iodine into the thyroid gland. }\end{array}$ \\
\hline $\begin{array}{l}\text { 2. Extrapolation to } \\
\text { humans, or broadly } \\
\text { applicable across } \\
\text { vertebrates/phyla }\end{array}$
\end{tabular} $\begin{array}{l}\text { Moderate-Strong. Iodine uptake via NIS is well conserved across } \\
\text { species Rat NIS used in this assay. }\end{array}$ \\
\hline $\begin{array}{l}\text { 3. Availability of } \\
\text { Resources }\end{array}$ & Strong. Materials readily available \\
\hline 4. Reference Chemicals & Strong. Several environmental chemicals tested. \\
\hline $\begin{array}{l}\text { 5. Assay Features/ } \\
\text { Limitations }\end{array}$ & $\begin{array}{l}\text { Non-radioactive method. Picomolar concentrations of test substance } \\
\text { detected with sensitivity similar to radioactivity-based method. } \\
\text { Available in 96-well format. Only tested currently in one laboratory. }\end{array}$ \\
\hline 6. Documentation & Waltz . et al., 2010 \\
\hline
\end{tabular}




\section{EVALUATION OF BLOCK \#3 ASSAYS - BINDING AND TRANSPORT IN SERUM}

34. The block of assays targeting assessment of thyroid hormone secretion and transport in serum encompasses three types of assays, those evaluating T3 and T4 bounding to thyroxin-binding globulin (TBG) and transthyretin (TTR) (Figure 4), and assays evaluating transport of thyroid hormone across the placenta. Several TBG and TTR assays are described in Part 2. No assays are presently available to assess transport of thyroid hormone across the placenta.

35. Analysis of the group of TBG and TTR assays indicates that they are at a high level (level A) of readiness for validation in the short term and could be proposed for OECD TG development.

\section{Circulation}
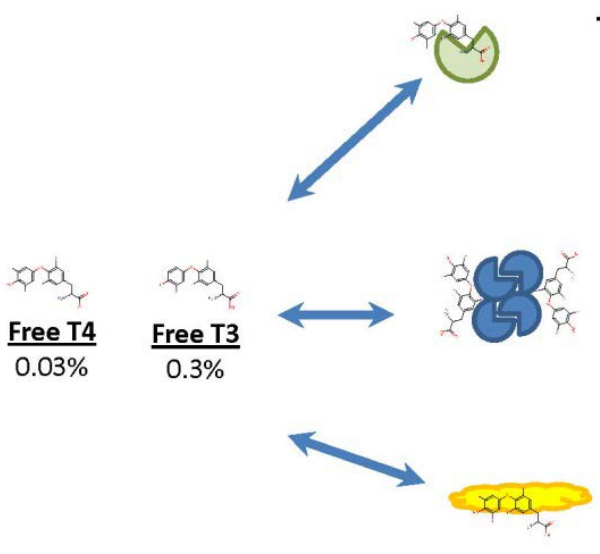

Thyroxine-Binding

Globulin

75\% of serum T4

$75 \%$ serum T3

\section{Transthyretin}

$20 \%$ of serum T4

$<5 \%$ serum T3

\section{Albumin}

$5 \%$ of serum T4 $20 \%$ serum T3
Free Fraction

Bound Fraction

Figure 4. Key Molecular Initiating Events related to serum TH binding proteins. The vast majority of both T4 and T3 in serum are associated with one of several serum carrier proteins. These proteins vary in their affinity for both hormones and the proportion of total serum hormone that they carry. Only unbound T4 or T3 $(0.03 \%$ and $0.3 \%$ of total serum hormone in adult human male) is available for cellular uptake. The relative amount of each hormone that is bound to each of the three proteins in human serum (adult male) is indicated. As TBG is not found in the adults of many species - including rodents and birds used in toxicity tests - T4 and T3 are mainly associated with transthyretin (TTR) in these species. Association of T4 with TTR has been shown to be inhibited by a variety of substances including several hydroxylated polychlorinated biphenyls (OH-PCBS). T4 binding to human TBG has been shown to be inhibited by 3-hydroxybrominated diphenyl ether 100 (OH-BDE100).

\begin{tabular}{|c|c|c|}
\hline TTR binding & TBG binding & $\begin{array}{c}\text { Transport over placenta \& } \\
\text { BBB }\end{array}$ \\
\hline A & A & Not Yet Analysed \\
\hline
\end{tabular}




\section{Thyroid Hormone Binding Proteins (TTR and TBG)}

36. Overview: In the blood, most of the thyroid hormone (T3 and T4) is bound to proteins. One of the primary functions of thyroid hormone serum binding proteins is to safeguard the body from the effects of abrupt fluctuations in hormonal secretion. The second is to efficiently recycle the body's supply of iodine by creating large macromolecules that limit iodine loss by preventing rapid metabolism of iodothyronine molecules and excretion of iodine-containing metabolites and iodine. In mammals, binding proteins are important for maternal to foetal transport of thyroid hormones and for delivery of T4 across the blood-brain-barrier. As such, xenobiotics that displace thyroid hormones from binding proteins may not only reduce the delivery of hormone to the site where it is required, but also transport xenobiotics to normally inaccessible sites of action, including the foetal brain. Resultant foetal brain thyroid hormone insufficiency in addition to direct action of the toxicant in the foetus contribute to the potential toxicity induced by this MOA.

37. Serum binding proteins are responsible for the maintenance of a large extrathyroidal pool of thyroid hormone of which only the minute fraction of free hormone $(<0.5 \%)$ is immediately available to tissues. TTR is the major T4 binding protein in birds, amphibians, fish, and rodents, xenobiotics that interfere with TTR binding of T4 may have greater negative effects in wildlife species than in humans. In contrast thyroxin-binding globulin (TBG) has the highest affinity and carries the majority of T4 in blood in humans, followed by transthyretin (TTR). Albumin is the most abundant but least effective binding protein in serum, due to its nonspecificity and low affinity for thyroid hormone.

38. Thyroid disrupting chemicals can impact circulating levels of free and bound thyroid hormones through their ability to interfere with serum binding proteins. Some PCBs, flame retardants, phthalates and phenols bind to TTR and in their bound form they may alter circulating levels of thyroid hormone by displacing T4 from TTR (Brouwer et al., 1998; Chauhan et al., 2000). The effects of xenobiotics on serum protein binding are not known to produce adverse effects. Although xenobiotics may interfere with binding of $\mathrm{T} 4$ to serum binding proteins and cause a reduction in circulating levels of total $\mathrm{T} 4$, this often does not cause a reduction in serum free $\mathrm{T} 4$. The implications of this xenobiotic action is unclear as the relationship of free or total serum hormone to tissue levels of thyroid hormone remains poorly understood. Although TTR carries only a minor part of the T4 pool in plasma in humans, it is the major T4 binding protein in some wildlife species (e.g., birds, amphibians, fish, and rodents). TBG is the primary binding protein in humans. Xenobiotics that interfere with TTR binding of T4 may have greater negative effects in wildlife species than in humans. However, TTR in humans is important for maternal to foetal transport of thyroid hormones and for delivery of T4 across the blood-brain-barrier. As such, xenobiotics bound to TTR or TBG may also be transported to normally inaccessible sites of action, including the foetal brain with a resultant decrease in foetal brain T4 levels. It has also been suggested that TTR binding is predictive of interactions with other proteins involved in the T4 pathway (Brouwer, 1991; Zoeller and Tan, 2007).

39. Several TH binding protein assays have been developed and published. They fall into 3 main types that differ primarily in their method of detection - displacement of radioactive T4; nonradioactive fluorescence displacement of T4; surface plasmon resonance biosensing.

40. Conclusion: The incorporation of screening assays for serum binding proteins is justified by the potential for this mechanism to disrupt hormone availability especially in the foetal brain, the potential for these assays to identify T4-like toxicants, the susceptibility of hormone binding displacement by a diverse suite of chemicals, and the existence of high throughput assays already available for this endpoint. Based on the state of science for serum binding proteins the assays for this modality falls into Level A with the caveat that some but not all of the protocols involve the use of radioisotopes. 


\begin{tabular}{|l|l|}
\hline TTR AND TBG BINDING ASSAYS \\
\hline 1. Biological Plausibility & $\begin{array}{l}\text { Strong. Displacement of thyroid hormone from binding sites on TTR } \\
\text { or TBG represents a plausible biological process that has been } \\
\text { documented for a number of chemicals. }\end{array}$ \\
\hline $\begin{array}{l}\text { 2. Extrapolation to } \\
\text { humans, or broadly } \\
\text { applicable across } \\
\text { vertebrates/phyla }\end{array}$ & $\begin{array}{l}\text { Strong. The assay uses human TTR and TBG and has also been } \\
\text { performed with source material from other species }\end{array}$ \\
\hline $\begin{array}{l}\text { 3. Availability of } \\
\text { Resources }\end{array}$ & Strong. Materials readily available \\
\hline $\begin{array}{l}\text { 4. Reference Chemicals } \\
\text { 5. Assay Features/ }\end{array}$ & $\begin{array}{l}\text { Strong Well characterized and readily available chemicals to use as } \\
\text { positive controls and which have been evaluated in several versions of } \\
\text { the assay. }\end{array}$ \\
\hline Limitations. & $\begin{array}{l}\text { Important target especially for transport to fetus. High throughput } \\
\text { format available and many chemicals have been tested. Assay types } \\
\text { differ primarily in their method of detection - displacement of } \\
\text { radioactive T4; non-radioactive fluorescence displacement of T4; } \\
\text { surface plasmon resonance biosensing. Technically, the assays can be } \\
\text { readily mastered. Some forms of the assay require expensive and } \\
\text { technically challenging platforms, others involve radioactive isotopes. }\end{array}$ \\
\hline 6. Documentation & $\begin{array}{l}\text { Hamers et al, 2008; Brouwer and vanden Berg, 1986; Cheek et al., } \\
\text { 1999; Hallgren and Darnerud, 2002; Lans et al., 1994. }\end{array}$ \\
\hline
\end{tabular}




\section{EVALUATION OF BLOCK \#4 ASSAYS - METABOLISM AND EXCRETION}

41. This block of assays targeting assessment of thyroid hormone metabolism and excretion encompasses three types of assays, those evaluating effects on the enzymatic systems involved in deiodination, glucuronidation and sulfation of thyroid hormones. Deiodination is the major pathway regulating $\mathrm{T} 3$ bioavailability in mammalian tissues (Figure 5).

42. Glucuronidation and sulfation assays were not analysed, but are important thyroid metabolism mechanisms, as glucuronidation of TH often precedes biliary fecal excretion of TH and in rats, stimulation of glucuronidation by various drugs and toxins may lead to lower $\mathrm{T}(4)$ and $\mathrm{T}(3)$ levels, a compensatory increase in thyrotropin (TSH) secretion, and goiter. Sulfation also plays a role in iodothyronine metabolism, accelerating deiodination of T3 and T4 to inactive metabolites (reverse T3, T2). Sulfoconjugation is important for foetal development, regulating the supply of T3 and facilitating the maternal-foetal exchange of sulfated iodothyronines, which is important for normal foetal development in the last trimester. In humans glucuronidates and sulfated iodothyronines can be hydrolysed to their precursors in gastrointestinal tract and various tissues. Thus, these conjugates can serve as a reservoir for biologically active iodothyronines (e.g., T4, T3, or T2). Although glucuronidation and sulfation are important thyroid metabolism mechanisms, assays for these processes were not considered here as they have been examined under DRP97 (OECD 2008, Jacobs et al 2008; 2013). They could however be addressed in update work.

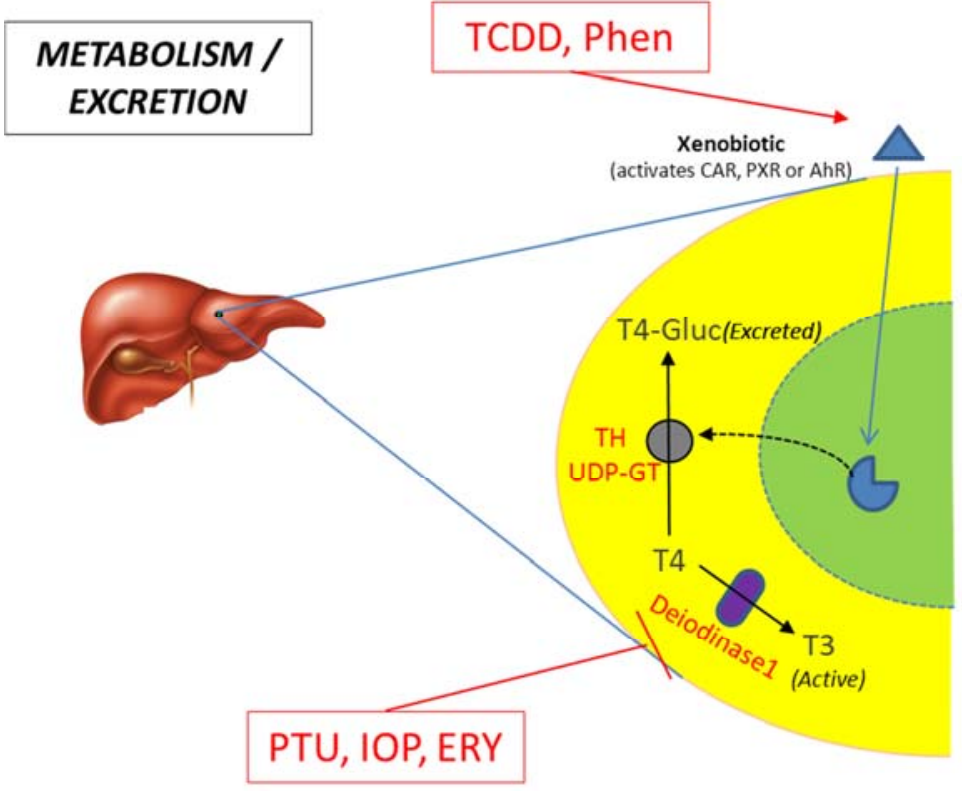

Figure 5: Metabolism of TH and the influence of xenobiotics. Thyroid hormones are metabolically deactivated and cleared from circulation by various pathways. This occurs primarily in the liver although some activity occurs in other tissues. Thyroxine is a prohormone that can be converted to the active hormone (T3) by enzymatic removal of an iodine from the outer ring or can be irreversibly deactivated by removal of an iodine from the inner ring. In the liver, both of these reactions can be performed by deiodinase 1 although the activation reaction is the primary reaction. The preferred substrate for the inner ring deiodination by D1 is T3 resulting in the inactive T2. Substances that block D1 action include propylthiouracil (PTU), iopanoate (IOP) and erythrosine (ERY).

Additionally, either T4 or T3 can be conjugated with glucuronide by UDP-glucuronosyl transferase (UDP-GT) or sulfate by sulfotransferases (SULT). The enzymes responsible for these reactions are expressed in response to the activation of xenobiotic-activated nuclear receptors: the Constitutive Androstane Receptor (CAR), Aryl Hydrocarbon Receptor (AhR) or the Pregnane X Receptor (PXR). Either one can be activated by a diversity of xenobiotics or activation of either receptor results in an increase in the rate of metabolism and excretion of T4 and T3. Prolonged exposures to activating substances can cause hypothyroidism especially when combined with dietary iodine deficiency of exposures to other thyroid active agents. Dioxins (TCDD) and phenobarbitol (Phen) have both been shown to induce increased T4 metabolism.

43. Limiting the analysis of metabolism to deiodination pathways, three groups of assays were considered: radioactive, HPLC based and colorimetric methods. Radioactivity-based assays are still the best balance between specificity and heavy material needs. HPLC is also a very sensitive method 
and offers a less biased approach because of the detection of all thyroid hormones metabolites. The colorimetric method is a promising alternative to the radioactive methods but is still limited in sensitivity and restricted to rich sources of enzymatic activity. Overall, the deiodination activity assays are still at a low to medium level of readiness for inclusion in the OECD Test Guideline programme for reasons that vary from across assay types from technical tosensitivity issues. In addition, it is recommended that a high throughput mRNA-based method for assessment of deiodinase activation could be developed to complement the activity assays.

\begin{tabular}{|c|c|c|c|c|c|}
\hline $\begin{array}{c}\text { Deiodination } \\
\text { inhibition }\end{array}$ & $\begin{array}{c}\text { Deiodination } \\
\text { up-regulation }\end{array}$ & $\begin{array}{c}\text { Hepatic } \\
\text { Nuclear } \\
\text { Receptor }\end{array}$ & $\begin{array}{c}\text { Glucuronidation } \\
\text { inhibition } \\
\text { B }\end{array}$ & $\begin{array}{c}\text { Glucuronidation } \\
\text { \& Sulfation } \\
\text { upregulation }\end{array}$ & $\begin{array}{c}\text { Sulfation } \\
\text { Inhibition }\end{array}$ \\
\hline DRP97 & B & $\begin{array}{c}\text { Covered in } \\
\text { DRP97 }\end{array}$ & $\begin{array}{c}\text { Covered in } \\
\text { DRP97 }\end{array}$ & $\begin{array}{c}\text { Covered in } \\
\text { DRP97 }\end{array}$ \\
\hline
\end{tabular}




\section{Deiodination Inhibition and Upregulation}

44. Overview: Three different deiodinases have been identified. Two separate enzymes possessing Outer Ring Deiodination (ORD) activity were identified in mammalian tissues and designated as type 1 and type 2 deiodinases (D1 and D2). Production of rT3 also results from deiodination of T4 by type 3 deiodinase (D3) (Chopra et al,, 1974; Roti et al., 1981; Kaplan et al., 1983).

45. Type I deiodinase (D1) is an integral membrane protein expressed mainly in liver, kidney, and thyroid. Subcellular localization is either the plasma membrane or endoplastic reticulum. rT3 is the preferred substrate (Visser, 1997). Although it catalyses the conversion of T4 to T3 much less effectively, D1 is considered to be the major source of circulating T3 (Visser, 1988, Kohrle et al. 1991). D1 is reduced under conditions of hypothyroidism and increased during hyperthyroidism.

46. Type II 5'-deiodinase (D2), is an obligate ORD and T4 is the preferred substrate. D2 activity is found in pituitary, brain, brown adipose tissue but also thyroid gland and skeletal muscle (Crantz et al., 1982; Salvatore et al., 1996a, b) and is localized in the cell at the endoplastic reticulum. D2 activity is increased by thyroidectomy and is not inhibited by PTU. D2 activity provides $50-80 \%$ of the intracellular T3 in brain tissue.

47. Type III deiodinase (D3) is an obligate IRD with T3 as the preferred substrate. D3 is expressed in placenta, uterus during gestation, brain, human embryonic liver (Santini et al. 1999; Galton et al, 1989; Bernal 2002). D3 is mainly at the plasma membrane on (with active centre facing extracellular space) and its supposed main function in thyroid hormone homeostasis is to limit tissue exposure to excess active hormone.

48. Recent in vivo developments in understanding of mRNA translation in the liver following xenobiotic-induced toxicity has been shown for D3 and the role that may have in supporting the liver to maintain its energy equilibrium, thereby avoiding the global disruption of the HPT axis (Dudek et al 2013).

49. Enzymes can be assessed for either changes in the expression levels of their mRNA but a more direct assessment is preferred as many postranslational controls of DI occur under normal physiological conditions. Using both approaches endocrine disruptors effects could be assessed.

50. As all mRNA of the three deiodinases were cloned in mammals, mRNA levels change based assays are possible using transfected cell lines. However no such assays are currently available.

51. DI activity assays have been used in research settings. In vitro deiodination activity is classically determined by incubating cells or homogenates with high amounts of ${ }^{125} \mathrm{I}$, Iodine-labelled thyroxine (T4) and required cosubstrates. As a measure of deiodination, the production of radioactive iodine and other physiological metabolites, in particular T3 (ORD activity) or reverse T3 (IRD activity), are determined and expressed e.g. as fmol $/ \mathrm{mg}$ protein/minute. The study performed by Freyberger et al., 2006 using outer ring radiolabelled reverse T3 as a model substrate aims to assess the inhibition of type-1 deiodinase (D1). It has a good reproducibility and provides quantitative assessment of the deiodinase type-1 activity. Its design allows thedetermination of the half maximal inhibitory concentration (IC50) for D1. Due to the position of the radiolabel on the outer ring, only outer ring, but not inner ring deiodination can be detected. All the assays of this type are described below grouped under the name of "radioactivity -based deiodinase activity assays". 
52. Recently, several methods of separating and quantifying iodothyronines using chromatography coupled to mass spectroscopy have been described (Butt et al., 2010). This analysis is more time consuming than the radioactivity method described above, and requires technical expertise in analytical chemistry and highly-specialized chromatography equipment. However, the method has the advantage of measuring not only iodine, but also all iodothyronines and, therefore, also provides information on T4 IRD. The latter study investigated the influence of various halogenated commodity chemicals, such as TBBPA, triclosan, BDE 47 on the formation of T3 from T4.

53. More recently Renko et al. (2012) developed a non-radioactive using a colorimetric method based on the redox reaction between As(III) and Ce(IV). In this reaction, iodine serves as a catalyst within this reaction between $\mathrm{Ce}$ (IV) and As(III) leading to an reduction of the intensity of colour of the Ce(IV) substrate. The more iodide present, the more deiodination, the faster the loss of yellow colour (Waltz et al., 2010). This assay offers a double advantage of combining the classical deiodination assay with an easily accessible photometric measuring iodide release and the protocol has been adapted to improve throughput. The colorimetric method represents a promising alternative to radioactivity-based assays, but is still limited in sensitivity and restricted to rich sources of enzymatic activity.

54. Conclusions. Currently three main types of DI assays are available: Methods for assessing deiodinases activities by monitoring radioactive iodine release from labelled T4, chromatographybased method for quantifying deiodinase products of thyroxin and colorimetric method for estimating the release of iodine from T4. The challenge for all assay methods is to find sufficient quantity of human type- 2 deiodinase activity to provide a model to test. Type- 1 deiodinase is more easily acquired as it is present in liver microsomes. When the effect of xenobiotic on enzyme activity is the desired endpoint, use of the three approaches using purified or semi purified enzymes could be used. Among the assays dealing with deiodinase activity, radioactivity based assays are still the best balance between specificity and heavy material needs. HPLC is also a very sensitive method and offers a less biased approach because of the detection of all thyroid hormones metabolites. 
RANKING PARAMETER ANALYSIS FOR DEIODINATION ASSAYS

\begin{tabular}{|c|c|}
\hline RADIOACTIVE ME & IODS FOR ASSESSING DEIODINASE ACTIVITY \\
\hline 1. Biological Plausibility & $\begin{array}{l}\text { Strong. Outer ring deiodination via } \mathrm{D} 1 \text { converts } \mathrm{T} 4 \text { to } \mathrm{T} 3 \text { in in } \\
\text { peripheral tissues. Local deiodination regulate } \mathrm{T} 3 \text { concentrations } \\
\text { within tissues via activity of D2 and D3 }\end{array}$ \\
\hline $\begin{array}{l}\text { 2. Extrapolation to } \\
\text { humans, or broadly } \\
\text { applicable across } \\
\text { vertebrates/phyla }\end{array}$ & Strong. Deiodinase activity strongly conserved across species \\
\hline $\begin{array}{l}\text { 3. Availability of } \\
\text { Resources }\end{array}$ & $\begin{array}{l}\text { Strong/Moderate. Limited access to D2 and D3 limit utility of assay } \\
\text { primarily to assessment of D1. The choice of substrates is limited by } \\
\text { the availability of isotope labelled molecules. }\end{array}$ \\
\hline 4. Reference Chemicals & PTU, T4, rT3, iopanoic acid, amiodarone \\
\hline $\begin{array}{l}\text { 5. Assay Features/ } \\
\text { Limitations }\end{array}$ & $\begin{array}{l}\text { D1 activity is determined using a microsomal preparation and reaction } \\
\text { buffers containing DTT as artificial cosubstrate. Enzymatic activity is } \\
\text { determined by radioactive method. Used in several laboratories with } \\
\text { comparable results. Broad range of dosages can be tested in a single } \\
\text { assay, but throughput is limited. D2 and D3 as substrate not readily } \\
\text { available so assay is limited to measures of peripheral diodination via } \\
\text { D1. }\end{array}$ \\
\hline 6. Documentation & $\begin{array}{l}\text { St Germain and Galton (review) 1997; Visser, 1988, Kohrle et al. } \\
1991\end{array}$ \\
\hline
\end{tabular}

\section{CHROMATOGRAPHY-BASED METHOD FOR ASSESSING DEIODINASE ACTIVITY}

1. Biological Plausibility

2. Extrapolation to humans, or broadly applicable across vertebrates/phyla 3. Availability of Resources

4. Reference Chemicals 5. Assay Features/ Limitations

Strong. This assay investigates test substance effects D1deiodinase activity, ans essential step in the conversion T4 to T3 in the periphery.

Strong. Deiodinase activity strongly conserved across species

Moderate Method requires highly specialize equipment and technical expertise in analytical chemistry. High maintenance, costly and time consuming. PTU, T4, rT3, iopanoic acid.

Microsomal fractions from mice liver are dissected and D1 activity is measured by iodine quantification in the media fraction using LC-MS. Does not require radioactivity but analytical chemistry is costly. Limited throughput. As with radioactivity based assays, assessments of D2 and D3 are limited by their relative scarcity.

6. Documentation $\quad$ Butt, Wang and Stapleton 2011 


\begin{tabular}{|l|l|}
\hline COLORIMETRIC METHOD FOR ASSESSING DEIODINASE ACTIVITY \\
\hline $\begin{array}{l}\text { 1. Biological Plausibility } \\
\begin{array}{l}\text { 2. Extrapolation to } \\
\text { humans, or broadly } \\
\text { applicable across } \\
\text { vertebrates/phyla } \\
\text { 3. Availability of } \\
\text { Resources } \\
\text { 4. Reference Chemicals }\end{array}\end{array}$ & $\begin{array}{l}\text { Strong. Outer ring deiodination via D1 converts T4 to T3 in in } \\
\text { peripheral tissues. Local deiodination regulate T3 concentrations } \\
\text { within tissues via activity of D2 and D3. }\end{array}$ \\
\hline & $\begin{array}{l}\text { Strong. The reaction being analysed is common to all vertebrates. } \\
\text { easily acquired. }\end{array}$ \\
$\begin{array}{l}\text { 5. Assay Features/ } \\
\text { Limitations }\end{array}$ & $\begin{array}{l}\text { Does not require radioactive isotopes or highly specialized } \\
\text { instrumentation. Low throughput. Limited sensitivity relative } \\
\text { radiometric assay. Possible interference with assay readout for iodine- } \\
\text { containing compounds. Use of aresenic in the assay may be } \\
\text { problematic due to its toxicity. As with all deiodinase assays described, } \\
\text { is limited to D1 dectection. }\end{array}$ \\
\hline 6. Documentation & \begin{tabular}{l} 
Renko et al., 2012 \\
\hline
\end{tabular}
\end{tabular}




\section{EVALUATION OF BLOCK \#5 ASSAYS - LOCAL CELLULAR CONCENTRATIONS}

55. The block of assays targeting assessment of local concentrations of thyroid hormone encompasses two types of assays, those evaluating effects on the thyroid hormones membrane transporters and the deiodinase activity in the peripheral tissues (Figure 6). The analysis of the deiodinase activity assays, which are applicable in this block as well, is outlined

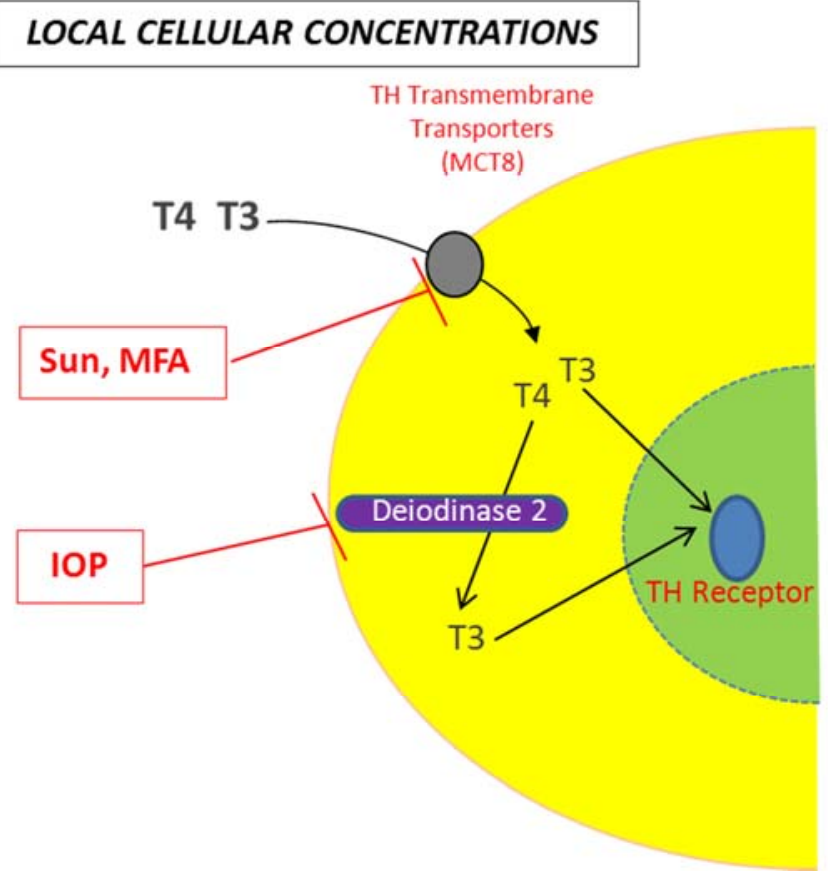
in the section above.

Figure 6: Uptake and metabolism of TH by target cells. Thyroid hormones are actively transported across cell membranes by any of a family of transporter proteins which vary in tissue distribution, and in their affinity for THs or their metabolites. The strongest evidence for the essential action of TH transporters in humans is for monocarboxylase transporter 8 (MCT8). Several substances, including tyrosine kinase inhibitor sunitinib (Sun) and antiinflammatory drug meclofenamic acid (MFA) that inhibit MCT8-mediated T3 uptake by target cells have been identified and exposure to these causes impaired TH physiology. Once in the target cell, T4 is converted to the active T3 via the action of D2. D2 action can be blocked by iopanoate (IOP).

56. Several TH membrane transporters assays are described in Part 2. The analysis of the assays with the view of their further development for inclusion in the OECD Test Guidelines programme concludes that the assays are at the highest level of readiness (Level A) or "in vitro/ex vivo assays that are ready for validation in the short term". Given that the activation of TH receptors, which is a function of the local TH concentrations, can easily and rapidly be assayed without the use of radioactive isotopes. It may be feasible to develop thyroid receptor transactivation assays that can probe substances for both modalities (i.e. inhibition of transmembrane transporters and inhibition/activation of receptor transactivation). If cell lines with clearly characterized transport systems are not available to develop a dual modality assay, models such as those described in this section could be used to develop transmembrane transporter assays independently.

\begin{tabular}{|c|c|}
\hline $\begin{array}{c}\text { TH membrane } \\
\text { transporters }\end{array}$ & Peripheral deidonation \\
\hline A & $\mathbf{C}^{*}$ \\
\hline & $\begin{array}{c}* \text { based on the analysis of } \\
\text { deiodination assays in the } \\
\text { previous section }\end{array}$ \\
\cline { 2 - 2 }
\end{tabular}




\section{Transmembrane Thyroid Hormone Transporter Assays}

57. Overview: Movement of thyroid hormones into and out of cells is achieved, physiologically, via active transport primarily through any of several highly-specific transporter molecules. The identity of these and evidence for their role in thyroid physiology and pathophysiology are subjects of much ongoing research and several excellent reviews (Hennemann et al., 2001; Heuer and Visser, 2009; Visser et al., 2011). At least five transporters - Monocarboxylase Transporter 8 (MCT8), MCT10, Organic Anion Transporter Protein 1C1 (OATP1C1), OATP3A1 and the large neutral amino acid transporters (LAT1/2) - have been identified through in vitro pharmacological studies as being high affinity, high specificity transporters of thyroid hormones and other iodothyronines. A large number of other molecules are also able to transport thyroid hormones although these have lower specificity and there is very little evidence that any of these low specificity molecules play any role in in vivo thyroid physiology (see Table 1 in (Visser, et al., 2011)). In contrast, there is strong evidence that the action of MCT8 plays a significant role in transporting T3 into target cells. Genetic defects that result in loss of function of MCT8 are associated with a congenital syndrome characterized by severe neurological defects, poor muscle development and altered circulating thyroid hormones (Dumitrescu et al., 2004; Friesema et al., 2004). The severity of deviation of circulating thyroid hormone levels from normal varies from case to case but elevated T3 and a tendency for reduced T4 and rT3 is consistent across cases (Schwartz et al., 2005). In addition, in mouse models in which MCT8 coding gene (Slc16a2) has been knocked out show a pattern of altered circulating thyroid hormones similar to that found in human cases (Dumitrescu et al., 2006). These studies and, in particular, the severe impact of impaired MCT8 activity in humans suggests that the activity this molecule is critical for normal human development.

58. Thyroid transporters in general and MCT8 in particular can also be inhibited by exogenous chemicals supporting their inclusion in a list of potential targets for thyroid toxicants. There have been many published studies showing that a number of pharmaceuticals can inhibit T3 uptake into a variety of cell types. Certain anti-inflammatory drugs (Lim et al., 1996; Topliss et al., 1989), benzodiazepines (Kragie and Doyle, 1992) calcium channel blockers (Powell et al., 2000; Scholz et al., 1997) and tyrosine kinase inhibitors (Braun et al., 2012) among other substances (Yan and Hinkle, 1993) can influence T3 uptake into cultured cells in vitro. Thyroxin uptake into liver cells is impaired by a furan fatty acid derivative (3-carboxy-4-methyl-5-propyl-2-furanpropanoic acid) and indoxyl sulfate which are found in the serum of uremic patients (Lim et al., 1993). Notably, neither of these substances impaired cellular T3 uptake in this latter study suggesting that the transporters for T4 and $\mathrm{T} 3$ are independent or at least have distinct sensitivities for inhibition. More recently Braun and colleagues reported that MCT8 was specifically inhibited by clinically-relevant concentrations of tyrosine kinase inhibitor drugs (Braun, et al., 2012). These authors suggest that this mechanism could explain the observed hypothyroidism and other thyroid-related pathologies in patients administered these drugs. Thyroxin transport into HEK293 cells stably transfected to express the human OATP1c1 transporter was also inhibited by a variety of substances (Westholm et al., 2009) including several fenamate non-steroidal anti-inflammatory drugs previously shown to inhibit T3 uptake into hepatic cell lines (Topliss, et al., 1989). Thus, there is ample evidence that transfer of both T3 and T4 across target cell membranes is vulnerable to inhibition by xenobiotics suggesting that these molecules could be targets for anti-thyroid toxicants. Moreover, there are many publications describing variations of an assay that measures inhibition of the movement of T3, T4 or reverse T3 into cultured cells. Each of these involves measuring the accumulation of ${ }^{125}$ I-labeled hormone in target cells after a very short incubation period $(<10 \mathrm{~min})$.

59. Conclusion: The development of screening assays for inhibition of thyroid hormone transmembrane transporters, particularly MCT8, is justified by the potential for this mechanism to impair thyroid physiology, the susceptibility of these to inhibition by diverse chemicals, the 
availability of rapid methods adaptable for moderate throughput assays. Based on the state of science for transmembrane transporters one could argue that the assay for this modality falls into Level A or "in vitro/ex vivo assays that are ready for validation in the short term" with the caveat that the protocol would involve the use of radioisotopes. In addition, developing such assays should be considered secondary as this modality (transmembrane transport) will also be screened by assays for effects on transcriptional transactivation of the TR as a cell line used for any validated THR transactivation assay would have to contain a functional transmembrane transporter. In addition the validation of these latter assays must involve a characterization of the transporter molecules active in the cell models used. The value of a standardized assay to determine T3 uptake into the cell will be in following up such a finding to clarify the mechanism(s) by which this inhibition is induced. 
RANKING PARAMETER ANALYSIS

\begin{tabular}{|c|c|}
\hline \multicolumn{2}{|c|}{ RADIOLABELLED THYROID TRANSMEMBRANE TRANSPORTERS ASSAYS } \\
\hline 1. Biological Plausibility & $\begin{array}{l}\text { Strong: Functional transporter molecules are essential for thyroid } \\
\text { hormone signalling. }\end{array}$ \\
\hline $\begin{array}{l}\text { 2. Extrapolation to } \\
\text { humans, or broadly } \\
\text { applicable across } \\
\text { vertebrates/phyla }\end{array}$ & $\begin{array}{l}\text { Moderate: Non-functional mutant MCT8 causes severe developmental } \\
\text { deficiencies in humans. Lack of impaired brain development MCT } 8 \\
\text { knock-out mice suggests that this role is not necessarily conserved } \\
\text { across the mammals. Impairing this mechanism alters thyroid } \\
\text { signalling across most vertebrates but it is not clear if the consequences } \\
\text { are equally severe in non-primates. }\end{array}$ \\
\hline $\begin{array}{l}\text { 3. Availability of } \\
\text { Resources }\end{array}$ & $\begin{array}{l}\text { Strong: The technology required for the assay is simple and widely } \\
\text { available. Cells expressing MCT } 8 \text { or MCT10 can transport T3 and T4 } \\
\text { across their membranes. High purity }{ }^{125} \mathrm{I}-\text { labelled T3 for MCT and T4 } \\
\text { for OATP1c1 assays are readily available. }\end{array}$ \\
\hline 4. Reference Chemicals & $\begin{array}{l}\text { Moderate. Several structurally distinct substances reported to impair } \\
\text { T3 uptake into cells including several classes of drugs that were not } \\
\text { designed to impair T3 or T4 uptake or physiology. One phytochemical } \\
\text { (phloretin) reported to act on this mechanism. Among anthropogenic } \\
\text { substances observed to inhibit TH uptake, no non-pharmaceuticals or } \\
\text { clinical substances identified. However, few substances tested so this } \\
\text { issue has yet to be broadly investigated. }\end{array}$ \\
\hline $\begin{array}{l}\text { 5. Assay Features/ } \\
\text { Limitations }\end{array}$ & $\begin{array}{l}\text { Assay measures uptake of radio-labelled T3 or T4 into cells MCT8 } \\
\text { MCT10 or OATP } 1 \mathrm{c} 1 \text {. Limited availability of positive pharmacological } \\
\text { substances. CV }<20 \% \text {, dynamic range } 15 \mathrm{X}>\text { than CV. Can } \\
\text { distinguish strong vs weak vs inactive substances. Substances with in } \\
\text { vivo action on hormone transport are positive in assay Uses } \\
\text { radioactivity. Need for a large number of cells to ensure sufficiently } \\
\text { measurable amounts of }{ }^{125} \text { I-hormone may limit the degree to which this } \\
\text { assay can be scaled up for HTP. Potential for some other MOAs to } \\
\text { interfere with the assay (i.e., assay sensitive to effects on cellular } \\
\text { energetics, ATP generation and binding, and probably membrane } \\
\text { potential). }\end{array}$ \\
\hline 6. Documenta & $\begin{array}{l}\text { Braun. et al. (2012); Friesema et al.2008; Kragie and D.Doyle 1992; } \\
\text { Westholm et al. 2009; Topliss, et al. } 1989\end{array}$ \\
\hline
\end{tabular}




\section{EVALUATION OF BLOCK \#6 ASSAYS - CELLULAR RESPONSES}

60. The block of assays targeting assessment of effects of xenobiotics on cellular processes affected by the activation of the TH nuclear receptors encompasses 5 types of assays. The assays monitor: (a) interactions with the ligand binding domain of the receptor; (b) effects on the activity of TR regulated genes; (c) interactions with TR co-regulators and (d) interaction with other receptors,

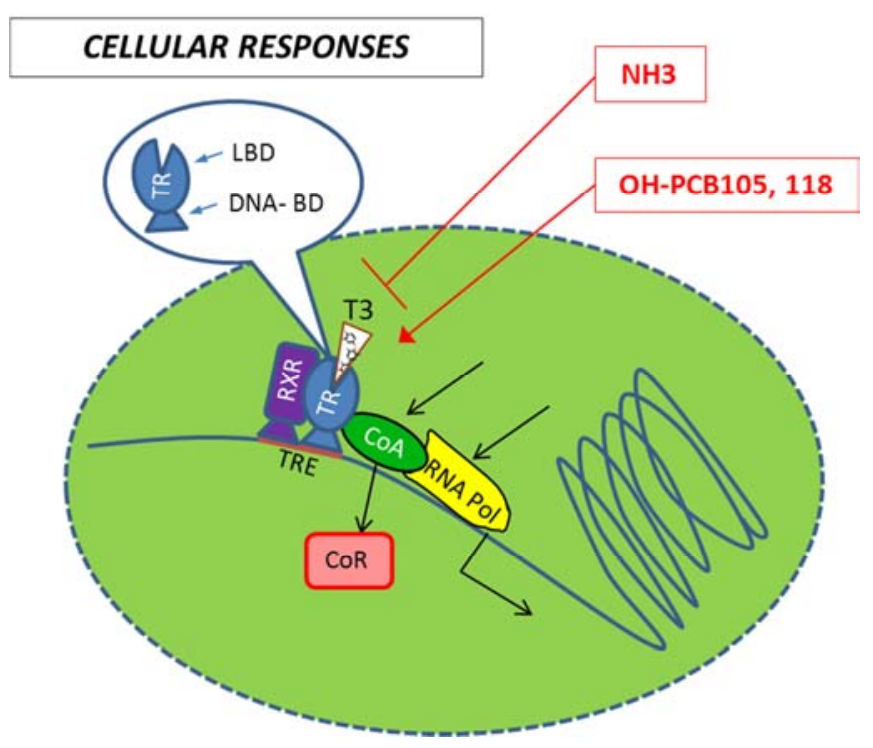
such as RXRs; and (e) non-nuclear mediated responses (Figure 7).

Figure 7: Transactivation of the thyroid hormone receptor by T3. Transcriptional responses to $\mathrm{TH}$ stimulation are mediated via thyroid hormone receptors alpha or beta (TR). Either form act as ligand-activated transcription factors associated as a heterodimer (with Retinoid X Receptor-RXR) with cognate DNA sequences termed thyroid response elements (TRE). The TR contains a ligand binding domain (LBD), with high affinity for T3, and a DNA binding domain (DNA-BD) which remains in tight contact with the TRE regardless of the presence of T3.In the unliganded state, $T R$ associates with a co-repressor and blocks transcription. Upon interaction with T3, the TR$R X R$ complex dissociates from the corepressor and binds a coactivator. This then attracts the polymerase complex resulting in transcription. Some synthetic molecules (e.g. NH3) inhibit TH-induced transcription while some metabolites of PCBs (particularly of PCBs 105 and $118-O H-P C B 105,118$ ) have been shown to induce TR transcriptional activation (Gauger et al., 2007).

61. The analysis of the assays that monitor interactions with the ligand binding domain of the receptors indicates moderate to low level (B to $\mathrm{C}$ ) of readiness for these assays.

62. The analysis of the assays that monitor effects on the activity of TR regulated genes focuses on 10 individual assays (representative assays are described in more technical detail in section 6.2 of Part 2) and ranks them relative to each other for their readiness for inclusion in the TG work plan. This analysis takes into account specific aspects of the assays, such as: 1) stable and/or constitutive expression; 2) full-length receptor DNA; 3) single thyroid hormone receptor isoform; 4) mammalian cell line; 5) commercial kit availability and 6) luciferase reporter gene activity. Seven of these assays could be ranked at Level A, and 3 at Level B of readiness.

63. The assays that monitor TR interaction with co-regulators have not been analysed.

64. Assays for monitoring interactions of TR with other receptors and non-nuclear mediated responses have not been described in Part 2 and are not analysed at present.

\begin{tabular}{|c|c|c|c|c|}
\hline $\begin{array}{c}\text { Binding to TR } \\
\text { LBD }\end{array}$ & $\begin{array}{c}\text { Effects of TR } \\
\text { transactivation }\end{array}$ & $\begin{array}{c}\text { Co-Regulator } \\
\text { interaction }\end{array}$ & $\begin{array}{c}\text { Activation } \\
\text { dimerization } \\
\text { partners TR } \\
\text { (RXR) }\end{array}$ & $\begin{array}{c}\text { Non-Nuclear } \\
\text { TR mediated } \\
\text { responses }\end{array}$ \\
\hline C to B & A to B & Not analysed & $\begin{array}{c}\text { Covered in } \\
\text { DRP 178 \& }\end{array}$ & Not analysed \\
\hline
\end{tabular}




\begin{tabular}{|l|l|l|l|l|}
\hline & & & DRP 97 & \\
\hline
\end{tabular}

\section{Binding to TR Ligand Binding Domain (LBD)}

65. Overview: It is well established that $\mathrm{T} 3$ and $\mathrm{T} 4$ critically regulate energy homeostasis, numerous metabolic pathways and the growth and differentiation of numerous organs. T4 is the predominant form of THs in the blood and is converted to T3 by deiodonases in cells. The majority of biological activities of THs are due to T3 due to its 10 to 15 -fold higher binding affinity for thyroid hormone nuclear receptors (TRs) than T4 (Togashi et al. 2005). TRs are members of a superfamily of ligand-dependent transcription factors that include steroid, retinoic acid, and vitamin D receptors (Aranda and Pascual, 2001). The ligand-bound TRs preferentially heterodimerize with retinoid X receptor $\alpha(\mathrm{RXR} \alpha)$ then bind directly to the DNA on TH response elements (TREs) (Lazar and Chin, 1990). RXR is also a heterodimerisation partner for further nuclear receptors such as PXR, CAR and the PPARs.

66. Thyroid signalling is mediated by transcription of target genes in the nucleus. Transcription can be activated (positive TRE) or repressed (negative TRE) by T3, depending on the cellular or tissue environment. This transactivation is due to the binding of T3 to its nuclear receptor. Binding of T3 to the ligand binding domain of the TR receptor is the first requisite step in the thyroid mediated gene transcription. There are two different TR isotypes TR $\alpha$ and TR $\beta$ each of which has two isoforms (TR $\alpha 1$ and $\alpha 2 \beta 1$ and $\beta 2$ ). In addition to T3 and T4, other ligands have the capacity to bind to TRs.

67. Several classes of environmental chemicals possess a high degree of structural similarity to THs, and thus have the potential to interfere with the binding of THs to TRs (Zoeller, 2005). For example, polychlorinated biphenyls bind to TR $\alpha$ and TR $\beta$ as antagonists and disrupt TR-mediated transcription. In addition, polybrominated and polychlorinated diphenylethers, 3,3',5trichlorobisphenol A; 3,3',5-tribromobisphenol A; and 3,3'-dibromobisphenol A have been reported to have antagonistic activity to TRs (Kitamura et al. 2005; Kudo and Yamauchi, 2005). However it is possible that different chemical species exerts different effects. PCBs for example may exert different actions on TRs depending on associated heterodimer partners, promoter structure, or different cofactors (Zoeller 2005).

68. Three basic type of assay systems have been developed to assess binding capacities of different ligands including natural hormones (T3), synthetic compounds (agonists GC1, GC24 antagonists NH-3) or chemical substances. These assays detect binding using the whole thyroid hormone receptor or may be limited to the ligand binding domain (LBD) of the TR.

69. The first category, the transfection assays, involves the entire TR into mammalian cells, yeast, or bacteria. Transfection assay permit dose-response studies and typically use reporter gene to quantify transactivation. A second category is based on affinity columns or cell free systems, and a third on in silico models. Affinity columns, cell free systems, or in silico approaches are not presently conducive to dose-response evaluations and will not be discussed further. However, a TR alpha/beta partner in cell free system will be included.

70. The following assays will be discussed further as they represent the most promising tools for the high-throughput in vitro screening of thyroid hormone receptor agonists and antagonists.

- Competitive binding assay for thyroid hormone receptor in MtT/E-2 cells

- TR alpha/beta activity using transient transfection in human cells

- TR alpha/beta partner in cell free system 
- Bacterial biosensors for screening isoform-selective ligands for human thyroid receptors $\alpha 1$ and $\beta 1$.

- Effects of TR Ligands on Hormone Dissociation Rates

71. Conclusion: Several TR LBD assays have been developed in different cell-based or cell-free systems. The levels of sensitivity and reproducibility in these systems depend on the nature of the transfection. Concentrations used are often higher than those environmentally found. However these kinds of assays could be really useful in a first approach or chemicals/TR interactions. However, due to the very specific T3 binding pocket, very few environmental chemicals have been shown to interfere with thyroid signalling by this mechanism.

\section{RANKING PARAMETER ANALYSIS}

Competitive binding assay for thyroid hormone receptor in nuclear fraction of MtT/E-2 cells

\begin{tabular}{|c|c|}
\hline 1. Biological Plausibility & $\begin{array}{l}\text { Moderate. Binding to the ligand binding domain of thyroid hormone } \\
\text { receptor is necessary to affect activation of thyroid hormone-mediated } \\
\text { gene transcription. However the TR pocket is specific and using only } \\
\text { LBD could modify general conformation. }\end{array}$ \\
\hline $\begin{array}{l}\text { 2. Extrapolation to } \\
\text { humans, or broadly } \\
\text { applicable across } \\
\text { vertebrates/phyla }\end{array}$ & $\begin{array}{l}\text { Strong. Conservation of TR across species. Development of assays to } \\
\text { compare LBD across species can be readily achieved. }\end{array}$ \\
\hline $\begin{array}{l}\text { 3. Availability of } \\
\text { Resources }\end{array}$ & Strong. All resources readily available. Assay requires radioactivity. \\
\hline 4. Reference Chemicals & Strong T3, T4, TBBPA, TCBPA, TMBPA, BPA \\
\hline $\begin{array}{l}\text { 5. Assay Features/ } \\
\text { Limitations }\end{array}$ & $\begin{array}{l}\text { Specific assay for binding of hormone to the receptor. High throughput } \\
\text { format. No patent. Requires radioactivity. Not a likely target of } \\
\text { environmental toxicants. }\end{array}$ \\
\hline 6. Documentation & Kitamura et al., 2005 \\
\hline
\end{tabular}

\section{TR alpha/beta activity using transient transfection in human cells}

\begin{tabular}{|l|l|}
\hline 1. Biological Plausibility & $\begin{array}{l}\text { Moderate. Binding to the ligand binding domain of thyroid hormone } \\
\text { receptor is necessary to affect activation of thyroid hormone-mediated } \\
\text { gene transcription. }\end{array}$ \\
$\begin{array}{l}\text { humans, or broadly } \\
\text { applicable across } \\
\text { vertebrates/phyla } \\
\text { 3. Availability of } \\
\text { Resources }\end{array}$ & $\begin{array}{l}\text { Strong. Conservation of TR across species. Development of assays to } \\
\text { compare LBD across species can be readily achieved. }\end{array}$ \\
$\begin{array}{l}\text { 4. } \text { Reference Chemicals } \\
\text { Strong. All cells and constructs are readily accessible }\end{array}$ \\
\hline $\begin{array}{l}\text { 5. Assay Features/ } \\
\text { Limitations }\end{array}$ & $\begin{array}{l}\text { Strong. Agonists T3, T4, TRIAC, TETRAC, GC1 (TR beta } \\
\text { preferential), GC24 (TR beta preferential), CO23 (TR alpha }\end{array}$ \\
\hline 6. Documentation & $\begin{array}{l}\text { TR alpha/beta activity assay using transient transfection in human } \\
\text { cells. High throughput format. No patent. Interaction with TR receptor } \\
\text { is not a likely target of environmental toxicants. }\end{array}$ \\
\hline
\end{tabular}




\begin{tabular}{|l|l|}
\hline \multicolumn{2}{|l|}{ TR alpha/beta partner in cell free system } \\
\hline 1. Biological Plausibility & $\begin{array}{l}\text { Moderate. Binding to the ligand binding domain of thyroid hormone } \\
\text { receptor is necessary to affect activation of thyroid hormone-mediated } \\
\text { gene transcription. }\end{array}$ \\
$\begin{array}{l}\text { 2. Extrapolation to } \\
\text { humans, broadly } \\
\text { applicable across } \\
\text { vertebrates/phyla } \\
\begin{array}{l}\text { Availability of } \\
\text { Resources }\end{array}\end{array}$ & $\begin{array}{l}\text { Strong. Conservation of TR across species. Development of assays to } \\
\text { compare LBD across species can be readily achieved }\end{array}$ \\
\hline $\begin{array}{l}\text { 5. Reference Chemicals } \\
\text { Limitations }\end{array}$ & Strong All cells and constructs easily acquired \\
\hline 6. Documentation & $\begin{array}{l}\text { Specific assay to detect interaction of chemicals at the receptor. High } \\
\text { throughput format. Cell free based system. No patent. LBD is not a } \\
\text { likely target of environmental toxicants. }\end{array}$ \\
\hline
\end{tabular}

Bacterial biosensors for screening isoform-selective ligands for human thyroid receptors $\alpha-1$ and $\beta-1$.

\begin{tabular}{|c|c|}
\hline 1. Biological Plausibility & $\begin{array}{l}\text { Moderate. Binding to the ligand binding domain of thyroid hormone } \\
\text { receptor is necessary to affect activation of thyroid hormone-mediated } \\
\text { gene transcription. }\end{array}$ \\
\hline $\begin{array}{l}\text { 2. Extrapolation to } \\
\text { humans, or broadly } \\
\text { applicable across } \\
\text { vertebrates/phyla }\end{array}$ & $\begin{array}{l}\text { Strong. Conservation of TR across species. Development of assays to } \\
\text { compare LBD across species can be readily achieved }\end{array}$ \\
\hline $\begin{array}{l}\text { 3. Availability of } \\
\text { Resources }\end{array}$ & Strong. All cells and constructs readily available \\
\hline 4. Reference Chemicals & Strong. T3, TRIAC, TBBPA \\
\hline $\begin{array}{l}\text { 5. Assay Features/ } \\
\text { Limitations }\end{array}$ & $\begin{array}{l}\text { Bacterial biosensors for screening isoform-selective ligands for human } \\
\text { thyroid receptors } \alpha-1 \text { and } \beta-1 \text {. No radioactivity required. High } \\
\text { throughput } 384 \text {-well format, moderate variability }(\mathrm{CV}<20 \%) \text {, no } \\
\text { patent. LBD is not a likely target of environmental toxicants. }\end{array}$ \\
\hline 6. Documentation & Gierach et al, 2012 \\
\hline
\end{tabular}

\section{\begin{tabular}{|l}
\hline Effects of TR Ligands on Hormone Dissociation Rates \\
\hline
\end{tabular}}

\begin{tabular}{|c|c|}
\hline 1. Biological Plausibility & $\begin{array}{l}\text { Moderate. Binding to the ligand binding domain of thyroid hormone } \\
\text { receptor is necessary to affect activation of thyroid hormone-mediated } \\
\text { gene transcription. }\end{array}$ \\
\hline $\begin{array}{l}\text { 2. Extrapolation to } \\
\text { humans, broadly } \\
\text { applicable across } \\
\text { vertebrates/phyla }\end{array}$ & Strong. Conservation of TR across species. \\
\hline $\begin{array}{l}\text { 3. Availability of } \\
\text { Resources }\end{array}$ & $\begin{array}{l}\text { Moderate. Requires radioactivity. Other assay component readily } \\
\text { available. }\end{array}$ \\
\hline 4. Reference Chemicals & Strong. GC24, GC1, NH-3 \\
\hline $\begin{array}{l}\text { 5. Assay Features/ } \\
\text { Limitations. }\end{array}$ & $\begin{array}{l}\text { High throughput format. Cell free based system. Limited sensitivity, } \\
\text { detection of test chemical effects are in the uM range. No patent. } \\
\text { Requires radioactivity. Interaction at the LBD of TR receptor is not a } \\
\text { likely target of environmental toxicants. }\end{array}$ \\
\hline 6. Documentation & Cunha Lima, et al., 2009 \\
\hline
\end{tabular}




\section{Effects of TR Transactivation}

72. Overview: As described above, thyroid signalling is mediated by transcription of target genes in the nucleus. Many steps in the pathway exist beyond simple binding to the TR before thyroid signalling is manifest. The ligand-bound TRs bind directly to the DNA on TH response elements (TREs), hexanucleotide motifs generally located upstream of the promoter region of target genes (Yen, 2001). TRs recognize consensus AGGTCA sequences that are organized in direct repeats (DR4), palindromes, or inverted palindromes. The unliganded TRs recruit co-repressors that function to repress transcription. The binding of $\mathrm{T} 3$ to $\mathrm{TRs}$ induces co-repressor release and co-activator recruitment that results in transcriptional activation. The two major TR isoforms are encoded by different genes, TR $\alpha$ and TR $\beta$. Both TR isoforms bind to T3 and mediate TH-regulated gene expression. Assays described in the previous section evaluate the potential for thyroid disruptors to interfere with the binding of $\mathrm{T} 3$ to the ligand binding domain on the receptor. Assays to be considered here determine the consequence of this binding, transcriptional activation.

73. Several in vitro bioassays (i.e., stable and transient) have been developed for the screening of TR ligands. These bioassays have traditionally been based on the quantification of a reporter enzyme and thus constitute an indirect measure of nuclear receptor activation in mammalian cells or yeasts (Zoeller, 2005; Jugan et al. 2007; Moriyama et al. 2002). These assays are fast and relatively simple, and yeast based assays are more cost effective and technically easier than mammalian in vitro assays. However, yeast assays primarily utilize only the ligand binding domain of TRs. Shiizaki et al. 2010 recently described the development of a novel reporter yeast assay system utilizing full-length human TRs and co-activators. There are further important biological considerations when prioritising which thyroid assays (mammalian/yeast) to take forwards for development purposes, depending upon the intended use. For instance yeast based assays have common issues, when inserting the different receptors, in that yeast have no, or only very limited metabolic capacities (Bovee et al., 2006, 2008a,b, 2010 cited in Jacobs et al 2013). This can actually be an advantage, as yeast based assays in which hormone receptors from a variety of species can be inserted along with reporter genes, may provide a comparative advantage for screening for EAS by providing clear information on hormone receptor activation due to a parent compound, as compared with assays that incorporate some (potential) downstream metabolism. Whilst previously they have been identified as suffering from limitations such a cell wall permeability and transport issues (see Jacobs et al., 2013 for a fuller review Shiizaki et al., 2010) in practice, from experience with the ER and AR systems, yeast systems may be useful to isolate a 'pure receptor mediated response' from one that might also include some residual metabolism, such as that occurring in vertebrate cell systems (Bovee and Pikkemaat, 2009, Jacobs et al 2013). Additional bioassays utilizing frog (Xenopus laevis) and fish (Oryzias latipes) recombinant cell lines for screening thyroid system disrupting chemicals have also been described (Sugiyama et al. 2005; Oka et al. 2012).

74. The recent advent and use of stably transfected luciferase reporter gene assays to study interference with either TR $\alpha$ and/or TR $\beta$-mediated signalling pathways by chemicals has conferred a greater level of specificity and sensitivity. These assays represent promising tools for the highthroughput in vitro screening of thyroid hormone receptor agonists and antagonists.

75. Conclusion: Several TR specific reporter gene assays have been developed, optimized, and verified using TH analogues of known potencies. The availability and use of stable in vitro assays, as opposed to transient assays, confers a greater level of sensitivity and reproducibility in examining the agonistic/antagonistic properties of suspected endocrine disrupting compounds. Therefore, based upon the current state of the science for TRs, several in vitro TR reporter gene assays may be designated as modality Level A. 
RXR specific assays are not discussed here as they are generally discussed in DRP 178 (OECD 2012).

\section{RANKING PARAMETER ANALYSIS}

\begin{tabular}{|l|l|}
\hline RAT PITUITARY TUMOUR CELL (GH3) REPORTER GENE ASSAY \\
\hline $\begin{array}{l}\text { 1. Biological Plausibility } \\
\text { 2. Extrapolation to } \\
\text { humans, or broadly } \\
\text { applicable across } \\
\text { vertebrates/phyla }\end{array}$ & $\begin{array}{l}\text { Strong. Reporter gene assay to detect TR-mediated activity of T3 T4 } \\
\text { and structurally related ligands. This luciferase reporter gene assay } \\
\text { targets TR-mediated activity. }\end{array}$ \\
$\begin{array}{l}\text { 3. Availability of } \\
\text { Resources }\end{array}$ & $\begin{array}{l}\text { Strong. The GH3 is a rat pituitary tumour cell line. TR conserved } \\
\text { across species. } \\
\text { available. The assay is not complex and can be conducted in any } \\
\text { laboratory with standard cell culture facilities. }\end{array}$ \\
\hline $\begin{array}{l}\text { 4. Reference Chemicals } \\
\text { 5. Assay Features/ }\end{array}$ & $\begin{array}{l}\text { Strong. T3, T4, acetic acid derivatives of T3 and T4. Hydroxyl } \\
\text { metabolites of PCBs and BDEs, TCBPA, TBBPA }\end{array}$ \\
\hline Limitations & $\begin{array}{l}\text { The cell line has previously been used study the interference of } \\
\text { compounds with thyroid hormone action. Mammalian cells, } \\
\text { constitutive, stable expression. Full TR } \alpha \text { and TRß expression. Simple, } \\
\text { rapid, high throughput, low variability, large dynamic range, high } \\
\text { sensitivity in picomolar range for T3. Used in Tox21 screen. Not } \\
\text { receptor specific. Assay is in A state of readiness but target is not a } \\
\text { common site of interference of thyroid signalling by environmental } \\
\text { toxicants. }\end{array}$ \\
\hline 6. Documentation & Freitas et al., 2011
\end{tabular}

\section{RAT PHEOCHROMOCYTOMA CELL (PC12) REPORTER GENE ASSAY}

1. Biological Plausibility

2. Extrapolation to humans, or broadly applicable across vertebrates/phyla

\section{Availability of} Resources

\section{Reference Chemicals}

5. Assay Features/ Limitations
Strong. Reporter gene assay targets the TR $\alpha-1$ isoform within the T3 signalling pathway

Strong.PC12 is a mammalian cell line, extensively used as a model for the induction of neuronal differentiation by nerve growth factor.

Strong. Basic cell culture protocols and materials are used and widely available. It is a standard reporter gene-based, whole cell assay. Assay components including plasmid constructs, TR $\alpha 1$-expressing PC12 cells easily acquired. The assay is not complex and can be conducted in any laboratory with standard cell culture facilities.

Strong. T3 Triac D-T3 T4 rT3, several TH analogues 3,3,5,5'tetrabromobisphenol, pentachlorophenol, 2,4,6-triiodophenol.

Luciferase reporter gene assay targets the TR $\alpha-1$ isoform within the T3 signalling pathway. Full TR $\alpha 1$ stably expressed in mammalian cells. Low intra and inter assay variation, detection at low $\mathrm{pM}$ concentrations of T3, large dynamic range, high throughput potential as has been optimized for multi-well microplates. Needs cytotoxicity assay incorporated. TR receptor expressed is of avian descent. Not a common site of interference of thyroid signalling by environmental 


\begin{tabular}{|c|c|}
\hline & toxicants. \\
\hline 6. Documentation & Jugan et al., 2007 \\
\hline \multicolumn{2}{|c|}{ HUMAN TR $\alpha$ and TR $\beta$ REPORTER GENE ASSAY SYSTEMS: INDIGO BIOSCIENCES } \\
\hline 1. Biological Plausibility & $\begin{array}{l}\text { Strong. TR } \alpha \text { and TR } \beta \text { Reporter Assay System kits assesses both } \\
\text { agonist and antagonist functional activity. }\end{array}$ \\
\hline $\begin{array}{l}\text { 2. Extrapolation to } \\
\text { humans, or broadly } \\
\text { applicable across } \\
\text { vertebrates/phvla }\end{array}$ & $\begin{array}{l}\text { Strong. Mammalian cell system with constitutive full-length human } \\
\text { TR } \alpha \text { and TR } \beta \text {. }\end{array}$ \\
\hline $\begin{array}{l}\text { 3. Availability of } \\
\text { Resources }\end{array}$ & $\begin{array}{l}\text { Strong. . Sold as independent kits that can be run in a } 96 \text {-well plate } \\
\text { format. Reagents are configured so that each group will comprise } 32 \\
\text { assays. If desired, however, reagents may be combined to perform } \\
\text { either } 64 \text { or } 96 \text { assays. }\end{array}$ \\
\hline 4. Reference Chemicals & $\begin{array}{l}\text { Strong. All materials provided in the kit, including positive and } \\
\text { negative controls. Other chemicals widely available for purchase. }\end{array}$ \\
\hline $\begin{array}{l}\text { 5. Assay Features/ } \\
\text { Limitations }\end{array}$ & $\begin{array}{l}\text { Human TR } \alpha \text { and TR } \beta \text { stable expression in mammalian cell line is } \\
\text { coupled with a highly responsive luciferase reporter gene. Low back } \\
\text { ground luminescence and highly selective for ligand activation of } \\
\text { hTRs. TR } \alpha \text { assessed independently of TR } \beta \text {. Sensitivity to T3 in nM } \\
\text { concentrations and displays large dynamic range and dose-response. } \\
\text { Commercially available in 96-well formats for cost of } \$ 1000 \text {. Assays } \\
\text { in an A state of readiness, but not a common site of interference of } \\
\text { thyroid signalling by environmental toxicants. Proprietary. }\end{array}$ \\
\hline 6. Documentation & $\begin{array}{l}\text { Yes, technical manual and } \\
\text { http://indigobiosciences.com/tr\%CE\%B1-nr1a1 }\end{array}$ \\
\hline
\end{tabular}

\begin{tabular}{|c|c|}
\hline \multicolumn{2}{|c|}{ GENEBLAZER ${ }^{\circledR}$ TR BETA DA ASSAY KIT - INVITROGEN INC SYSTEM } \\
\hline 1. Biological Plausibility & $\begin{array}{l}\text { Strong. This TR } \beta \text { Reporter Assay System kit assesses both agonist } \\
\text { and antagonist functional activity. }\end{array}$ \\
\hline $\begin{array}{l}\text { 2. Extrapolation to } \\
\text { humans, or broadly } \\
\text { applicable across } \\
\text { vertebrates/phyla }\end{array}$ & $\begin{array}{l}\text { Strong. HEK } 293 \text { T cell system stably transfected with the ligand- } \\
\text { binding domain of human TR } \beta \text { coupled with a } \beta \text {-lactamase reporter } \\
\text { gene. }\end{array}$ \\
\hline $\begin{array}{l}\text { 3. Availability of } \\
\text { Resources }\end{array}$ & $\begin{array}{l}\text { Strong. All assay components are sold commercially as a kit that can } \\
\text { be run in a } 384 \text {-well plate. }\end{array}$ \\
\hline 4. Reference Chemicals & Strong. Positive controls included in kit \\
\hline $\begin{array}{l}\text { 5. Assay Features/ } \\
\text { Limitations }\end{array}$ & $\begin{array}{l}\text { Cell system stably transfected with the full ligand-binding domain of } \\
\text { human TR } \beta \text { coupled with a } \beta \text {-lactamase reporter gene. Both agonist } \\
\text { and antagonist activity can be detected. Assay performance acceptable } \\
\text { under variable conditions, including DMSO concentration, cell } \\
\text { number, stimulation time, and substrate loading time. Highthroughput } \\
\text { in } 384 \text {-well format for } \sim \$ 1000 \text {. ToxCast results indicate poor } \\
\text { correlation with very limited EDSP/OECD Reference chemicals and } \\
\text { assay not selected for ToxCast screen. In 'A' state of readiness but not } \\
\text { a common site of interference of thyroid signalling by environmental } \\
\text { toxicants. Proprietary. }\end{array}$ \\
\hline 6. Documentation & Yes, technical manual and protocol provided. \\
\hline
\end{tabular}


http://products.invitrogen.com/ivgn/product/K1389

\begin{tabular}{|c|c|}
\hline \multicolumn{2}{|c|}{ XENOPUS LAEVIS CELL LINE REPORTER GENE ASSAY XL58-TRE-LUC TR $\beta$} \\
\hline 1. Biological Plausibility & $\begin{array}{l}\text { Strong.. Xenopus laevis widely used as a laboratory animal; } \\
\text { development and expression of its gene are well characterized. X. } \\
\text { laevis has been approved as an experimental model for evaluating the } \\
\text { effects of endocrine-disrupting chemical (EDCs) in amphibians by } \\
\text { OECD. }\end{array}$ \\
\hline $\begin{array}{l}\text { 2. Extrapolation to } \\
\text { humans, or broadly } \\
\text { applicable across } \\
\text { vertebrates/phyla }\end{array}$ & $\begin{array}{l}\text { Strong. TR receptor highly conserved across species The transgene of } \\
\text { the LV system can be introduced into organisms as well as cell lines - } \\
\text { vector system can be used for expanded host species, especially cold- } \\
\text { blooded lower vertebrates }\end{array}$ \\
\hline $\begin{array}{l}\text { 3. Availability of } \\
\text { Resources }\end{array}$ & $\begin{array}{l}\text { Strong. Basic cell culture protocol and materials are used and widely } \\
\text { available. The assay is not complex and can be conducted in any } \\
\text { laboratory with standard cell culture facilities }\end{array}$ \\
\hline 4. Reference Chemicals & $\begin{array}{l}\text { Strong. Positive and negative pure chemicals are widely available. T3 } \\
\text { Triac T4 rT3 } 17 \beta \text {-estradiol - Specificity is in agreement with the } \\
\text { binding specificity of amphibian and mammalian }\end{array}$ \\
\hline $\begin{array}{l}\text { 5. Assay Features/ } \\
\text { Limitations }\end{array}$ & $\begin{array}{l}\text { Stable expression of full TR } \beta \text { with high thyroid hormone } \\
\text { responsiveness. The transgene can be introduced into organisms as } \\
\text { well as cell lines. Vector system can be used for expanded host species, } \\
\text { especially cold-blooded lower vertebrates. High sensitivity and } \\
\text { reproducibility, rapid and useful for highthroughput. Limited by X. } \\
\text { Laevis T3-response elements. In 'A' state of readiness but not a } \\
\text { common site of interference of thyroid signalling by environmental } \\
\text { toxicants. }\end{array}$ \\
\hline 6. Documentation & Sugiyama et al., 2005a; $2005 \mathrm{~b}$ \\
\hline
\end{tabular}

\section{YEAST REPORTER ASSAY SYSTEMS FOR TR $\alpha$ and TR}

1. Biological Plausibility

2. Extrapolation to humans, or broadly applicable across vertebrates/phyla

3. Availability of Resources

4. Reference Chemicals

5. Assay Features/ Limitations
Strong. The assay targets TR $\alpha$ or TR $\beta$ ligands and examines responses to endogenous THs and other chemicals.

Strong. TRs highly conserved across species. Although conducted in yeast, the reporter assay utilizes intact human TRs cDNA and coactivator.

Strong. Basic cell culture protocols and materials are used and widely available. The assay is not complex and can be conducted in any laboratory with standard cell culture facilities.

Strong. Highly responsive four model toxic compounds suspected to have thyroid-disrupting activity were evaluated.

Full human TR $\alpha$ or TR $\beta$ cDNA stable expression in yeast cells. In contrast to endogenous TR ligands, high doses $\left(>10^{-6} \mathrm{M}\right)$ of the test chemicals required for activation and only four model chemicals tested thus far. Agonist and antagonist activity observed. Responses to endogenous ligands correlated well with mammalian cells. Technically simple, cost effective, 96-well plate format. Not as sensitive as in vivo $\mathrm{X}$. Laevis assay possibly due to reporter gene and its substrates. Bgalactosidase was utilized as activity of this enzyme can be detected without complex extraction procedure. Possibly higher sensitivity 


\begin{tabular}{|l|l|}
\hline & $\begin{array}{l}\text { achieved using different substrates. In 'A' state of readiness but not a } \\
\text { common site of interference of thyroid signalling by environmental } \\
\text { toxicants }\end{array}$ \\
\hline 6. Documentation & Shiizaki et al, 2010 \\
\hline
\end{tabular}

\begin{tabular}{|c|c|}
\hline \multicolumn{2}{|c|}{ HUMAN HEPG2 CELL REPORTER GENE ASSAY } \\
\hline 1. Biological Plausibility & Strong. Reporter gene assay to detect TR-mediated activity. \\
\hline $\begin{array}{l}\text { 2. Extrapolation to } \\
\text { humans, or broadly } \\
\text { applicable across } \\
\text { vertebrates/phyla }\end{array}$ & $\begin{array}{l}\text { Strong. TRs highly conserved across species. This assay expresses full } \\
\text { human TR } \alpha \text { and } \beta \text {. Metabolism potential maintained in this cell line. } \\
\text { Liver is primary tarfget organ of T3 metabolism and action. }\end{array}$ \\
\hline $\begin{array}{l}\text { 3. Availability of } \\
\text { Resources }\end{array}$ & $\begin{array}{l}\text { Strong. No technically challenging platforms. All components of } \\
\text { assay and control test substances readily available. }\end{array}$ \\
\hline 4. Reference Chemicals & $\begin{array}{l}\text { Strong. Positive and negative pure chemicals are widely available.- } \\
\text { Synthetic TR agonist GC- } 1 \text {, the antagonists NH-3, and endocrine } \\
\text { disrupting compounds OMC and } 4 \mathrm{NP} \text { known to exert thyroid effects in } \\
\text { vivo behaved as excepted. }\end{array}$ \\
\hline $\begin{array}{l}\text { 5. Assay Features/ } \\
\text { Limitations }\end{array}$ & $\begin{array}{l}\text { Cells express full human TR } \alpha \text { and TR } \beta \text {. Cells maintain a degree of } \\
\text { metabolic potential possessing residual P450 activity, and can be } \\
\text { transfected with various CYPs. Activation and competition assays } \\
\text { performed (i.e., exposure to test chemical with and without T3). Can } \\
\text { distinguish between agonists, partial agonists and antagonists of TR. } \\
\text { Assay variability is low }(\mathrm{CV}<5 \% \text { ) but performance limited to one } \\
\text { laboratory. EDC concentrations were limited to a maximum } \\
\text { concentration of } 10 \mathrm{uM} \text { to distinguish cytotoxic from endocrine } \\
\text { disrupting effects. Co-transfection with TR expression plasmids } \\
\text { increases dynamic range and maximal induction. Under such } \\
\text { conditions }>100 \text {-fold induction efficiencies can detect weak EDCs. } \\
\text { Results similar to in vivo effects on expression of hepatic gene D101 } \\
\text { with greater sensitivity in reporter assay. Limited as transient } \\
\text { transfection, potential for false negatives. In 'B' state of readiness but } \\
\text { not a common site of interference of thyroid signalling by } \\
\text { environmental toxicants. }\end{array}$ \\
\hline 6. Documentation & Hofmann et al., 2009 \\
\hline
\end{tabular}

\begin{tabular}{|l|l|}
\hline \multicolumn{2}{|l|}{ RAT PITUITARY CELL LINE MTT/E-2 LUCIFERASE REPORTER ASSAY } \\
\hline 1. Biological Plausibility & $\begin{array}{l}\text { Strong. Utilising a luciferase gene expression signal this assay } \\
\text { measures the response to T3 or T4 that in the animal model is likely to } \\
\text { increase the proliferation of the MTT/E-2 cells. }\end{array}$ \\
$\begin{array}{l}\text { 2. Extrapolation to } \\
\text { humans, or broadly } \\
\text { applicable across } \\
\text { vertebrates/phyla }\end{array}$ & $\begin{array}{l}\text { Strong. Thyroid hormone induced cell proliferation is a response } \\
\text { highly conserved across species. Mammalian cell line. }\end{array}$ \\
$\begin{array}{l}\text { 3. Availability of } \\
\text { Resources }\end{array}$ & $\begin{array}{l}\text { Strong. Cell culture protocol and materials are used and widely } \\
\text { available. The assay is not complex and can be conducted in any } \\
\text { laboratory with standard cell culture facilities. }\end{array}$ \\
\hline 4. Reference Chemicals & Strong. Positive and negative control substances widely available (T3, \\
\hline
\end{tabular}




\begin{tabular}{|l|l|}
\hline & $\begin{array}{l}\text { T4, dexamethasone, } 17 \beta \text {-estradiol, progesterone, dihydrotestosterone). } \\
\text { Bithionol, closantel and rafoxanide were obtained from collaborators. }\end{array}$ \\
\hline $\begin{array}{l}\text { 5.Assay Features/ } \\
\text { Limitatins }\end{array}$ & $\begin{array}{l}\text { Rat cells with transient transfection of full TR } \alpha \text { or TR } \beta \text {. Serum free } \\
\text { medium and highly sensitive }\left(\mathrm{T} 310^{-11} \mathrm{M}\right) \text { Low variability low }(<5 \%) . \\
\text { Compounds structurally related to T3 exhibit thyroid-hormone like } \\
\text { activity at a range of } 10^{-6} \text { to } 10^{-7} \mathrm{M} \text {. No effect of negative controls. } \\
\text { Assay in a 'B' state of readiness but not a common site of interference } \\
\text { of thyroid signalling by environmental toxicants. }\end{array}$ \\
\hline 6. Documentation & Matsubara et al., 2012. \\
\hline
\end{tabular}

\begin{tabular}{|c|c|}
\hline \multicolumn{2}{|c|}{ MONKEY KIDNEY FIBROBLAST CV-1 REPORTER GENE ASSAYS } \\
\hline 1. Biological Plausibility & $\begin{array}{l}\text { Strong. Reporter gene assay targets the TR } \alpha \text { and TR } \beta \text { isoforms within } \\
\text { the T3 signalling pathway in a monkey kidney cell line (CV-1). Cell } \\
\text { line widely used to examine regulation of gene expression by T3. . }\end{array}$ \\
\hline $\begin{array}{l}\text { 2. Extrapolation to } \\
\text { humans, or broadly } \\
\text { applicable across } \\
\text { vertebrates/phyla }\end{array}$ & Strong. Response is highly conserved across species and cell types. \\
\hline $\begin{array}{l}\text { 3. Availability of } \\
\text { Resources }\end{array}$ & $\begin{array}{l}\text { Strong. Basic cell culture protocols and materials are used and widely } \\
\text { available. The assay is not complex and can be conducted in any } \\
\text { laboratory with standard cell culture facilities. }\end{array}$ \\
\hline 4. Reference Chemicals & $\begin{array}{l}\text { Moderate. Positive control substances along with } 3 \text { model potentiating } \\
\text { compounds of known potencies were evaluated. }\end{array}$ \\
\hline $\begin{array}{l}\text { 5. Assay Features/ } \\
\text { Limitations }\end{array}$ & $\begin{array}{l}\mathrm{CV}-1 \text { is monkey kidney cell line that does not express endogenous TRs } \\
\text { but retains some metabolic capability via } 17 \text { alpha oxidase and } 5 \text { alpha } \\
\text { reductase. The acceptance level was set at } \mathrm{p} \leq 0.05 \text {. Xenopus TRs } \\
\text { assessed, transient transfection. Limited compounds tested. False } \\
\text { negative detected in that hexabromocyclododecane (HBCD) did not } \\
\text { shown any TR } \alpha \text { or TR } \beta \text { activation. Not a common site of interference } \\
\text { of thyroid signalling by environmental toxicants. }\end{array}$ \\
\hline 17. Documentation & Limited. Schriks et al., 2007. \\
\hline
\end{tabular}

\begin{tabular}{|l|l|}
\hline VERO CELL THYROID HORMONE REPORTER BETA REPORTER GENE ASSAY \\
\hline 1. Biological Plausibility & $\begin{array}{l}\text { Strong. The Vero cell reporter system is African green monkey kidney } \\
\text { cell line shown to have an appropriate response to the natural TR } \\
\text { ligand T3. }\end{array}$ \\
\hline $\begin{array}{l}\text { 2. Extrapolation to } \\
\text { humans, or broadly } \\
\text { applicable across } \\
\text { vertebrates/phyla }\end{array}$ & Strong. TR receptor activation is highly conserved across species. \\
\hline $\begin{array}{l}\text { 3. Availability of } \\
\text { Resources }\end{array}$ & $\begin{array}{l}\text { Strong. Basic cell culture protocols and materials are used and widely } \\
\text { available. The assay is not complex and can be conducted in any } \\
\text { laboratory with standard cell culture facilities. }\end{array}$ \\
\hline 4. Reference Chemicals & $\begin{array}{l}\text { Weak. Endogenous ligands readily available but none of the tested } \\
\text { chemicals exhibited TR agonistic activity in the assay. }\end{array}$ \\
\hline $\begin{array}{l}\text { 5 Assay Features/ } \\
\text { Limitations }\end{array}$ & $\begin{array}{l}\text { Monkey cell line with transient transfection of TR receptor. } \\
\text { Luciferase readout. Cells do not contain endogenous receptors.. BPA } \\
\text { and DEHP had weak antagonist activity but neither of these chemicals }\end{array}$ \\
\hline
\end{tabular}




\begin{tabular}{|l|l|}
\hline & $\begin{array}{l}\text { could reach the } \mathrm{RIC}_{20} \text { in the tested concentration range. The } \\
\text { cytotoxicity determined by MTT assay. No cytotoxic effects were } \\
\text { observed. Very limited data and technical information available. In 'B' } \\
\text { state of readiness. Not a common site of interference of thyroid } \\
\text { signalling by environmental toxicants. }\end{array}$ \\
\hline 6. Documentation & Limited documentation but see Sun et al., 2012 \\
\hline
\end{tabular}




\section{EVALUATION OF BLOCK \#7 ASSAYS - RELEVANT SHORT-TERM ASSAYS INTEGRATING MULTIPLE MOAS}

76. This block of assays targets assessment of effects of xenobiotics on various MOAs leading to disruption thyroid function using zebrafish, sea urchin, and xenopus embryo, or organ explants cultures. These assays use whole animals or explants from whole animals and therefore potentially address multiple, integrated mechanisms of action. They are not strictly in vitro assays and were considered separately as ex vivo assays because they focus on thyroid functions and would be highly informative. Some of these assays have been used for a long time (xenopus metamorphosis) or sufficient data has become available for their validation and development of OECD Test Guidelines (GFP-Xenopus laevis embryo assay, TG under development in Project 2.39).

77. In this section a zebrafish embryo assay and a thyroid gland explant culture from Xenopus laevis assay are analysed for their readiness for inclusion in the OECD Test Guideline programme and were found to be at a medium (level B) of readiness. The sea urchin assay and short-term Xenopus metamorphosis were not analysed at this time.

\begin{tabular}{|c|c|c|c|c|}
\hline $\begin{array}{c}\text { Zebrafish } \\
\text { Embryo }\end{array}$ & $\begin{array}{c}\text { Sea Urchin } \\
\text { Metamorphosi } \\
\text { s Assay }\end{array}$ & $\begin{array}{c}\text { GFP-Xenopus } \\
\text { Embryo }\end{array}$ & $\begin{array}{c}\text { Short Term } \\
\text { Xenopus } \\
\text { Metamorphos } \\
\text { is Assay }\end{array}$ & $\begin{array}{c}\text { Thyroid } \\
\text { Gland } \\
\text { Explant } \\
\text { Culture }\end{array}$ \\
\hline B & Not analysed & $\begin{array}{c}\text { TG under } \\
\text { development } \\
\text { in Project } \\
2.39\end{array}$ & Not analysed & B \\
\hline
\end{tabular}




\section{Zebrafish Eleutheroembryo Thyroid Assay}

78. Overview: All vertebrates, including teleost fish, share several features of thyroid development and physiology. The study of zebrafish thyroid development and function has been facilitated by the transparent nature and rapid development of the embryo, allowing the ready application of mutagenic screens, cell linage tracing and fate mapping, whole mount in situ and immunohistochemical analysis of orthologous (relative to mammalian) gene expression and gene array studies.

79. The endpoint measured in this assay is T4 concentration in thyroid follicles of 5 days postfertilization (dpf) zebrafish following 3 days of exposure to a water-borne chemical. On day $5 \mathrm{pf}$, larvae are fixed, and subjected to whole-mount immunofluorescence analysis using a polyclonal rabbit anti-T4 antibody. Total T4 immunofluorescence in follicular cells is then quantified via image analysis and compared with untreated or vehicle-treated controls.

80. The assay was developed using MMI and PTU, potassium perchlorate $\left(\mathrm{KClO}_{4}\right)$, amiodaron, and exogenous T3 (Raldua and Babin, 2009). The assay was then used to screen the thyroiddisrupting effect of several chemicals exposed at the Maximum Tolerated Concentrations (MTC): 2,4Dichlorophenoxyacetic acid (2,4-D), 1,1-bis(4-chlorophenyl)-2,2,2-trichloroethane (DDT), 4nonylphenol (4-NP), methylmercury ( $\mathrm{MeHg}$ ) and fenoxicarb and atrazine as negative controls. A subsequent study screened MMI, KClO4, DDT and 22 additional chemicals (Thienpont et al. 2011). A positive was defined as a statistically significant difference in fluorescent signal between treated and vehicle control animals. In the second study, verification of thyroid effects was carried out by comparing concentration-response (EC50) of T4 signal with lethality (LC50) to determine a Thyroid Disrupting Index (LC50/EC50). There is a potential for confounding results using this measure as it is possible that T4 signalling could be altered by non-specific factors at concentrations below those causing lethality.

81. Conclusion: This assay has strong potential for identifying water soluble chemicals that directly affect thyroid function, and may be more generally applicable (e.g. to chemicals that have indirect function). Based on strong conservation of mechanism, this assay has the potential to be relevant to vertebrates in general if species differences in metabolism are taken into account. Downsides of the assay include the labour-intensive and potentially subjective nature of manual image capture, as well as the requirement of proximity to a fish breeding facility. In addition, in a whole animal system, it is possible that T4 signalling could be altered by non-specific factors at concentrations below those causing lethality and therefore determinations regarding mechanism of action would need to be made as part of a weight-of-evidence evaluation. Another potential consideration is interference by the chorion for large and/or lipophilic substances: although exposure in this protocol begins on day 2 pf when most embryos will have hatched, some embryos may remain in the chorion until day $3 \mathrm{pf}$. Permeability of the chorion can be enhanced by the use of a solvent such as DMSO (Kais et al. 2013). Next steps in assay development would include development of a standardized protocol, measurement of in situ chemical concentrations, and repeat experiments designed to evaluate the sensitivity, reproducibility and transferability of the assay. The assay could be improved by the inclusion of additional endpoints including quantification of mRNA expression levels of different genes (e.g. by qPCR), or the concentrations of different proteins in the embryo (e.g. by ELISA). This would allow analysis of many different components of the thyroid system in the same assay. 
RANKING PARAMETER ANALYSIS

\begin{tabular}{|c|c|}
\hline \multicolumn{2}{|c|}{ ZEBRAFISH ELEUTHEROEMBRYO THYROID ASSAY } \\
\hline 1. Biological Plausibility & $\begin{array}{l}\text { Strong. Synthesis of T4 in in the thyroid follicle is a well-established } \\
\text { and highly conserved key event in thyroid signalling. Although not } \\
\text { directly assessing T4 synthesis, the endpoint (T4 in the thyroid) is the } \\
\text { affected by several documented initiating events. }\end{array}$ \\
\hline $\begin{array}{l}\text { 2. Extrapolation to } \\
\text { humans, or broadly } \\
\text { applicable across } \\
\text { vertebrates/phyla }\end{array}$ & $\begin{array}{l}\text { Strong to Moderate. Main elements of thyroid development and } \\
\text { function are conserved between fish and mammals including humans. } \\
\text { However, there are some differences in structure and feedback } \\
\text { mechanisms that may affect translatability of results. In addition, } \\
\text { metabolic capacity of the zebrafish larva will need to be considered. }\end{array}$ \\
\hline $\begin{array}{l}\text { 3. Availability of } \\
\text { Resources }\end{array}$ & $\begin{array}{l}\text { Moderate. The assay itself is not complex but requires histological } \\
\text { techniques and high resolution fluorescent microscopy. The assay } \\
\text { requires access to a zebrafish breeding facility. }\end{array}$ \\
\hline 4. Reference Chemicals & $\begin{array}{l}\text { Moderate. Well characterized positive chemicals that include } \\
\text { pharmaceuticals, industrial chemicals and pesticides; thus far } \\
\text { approximately } 25 \text { chemicals have been tested (Thienpont et al. 2011). }\end{array}$ \\
\hline 5. Features /Limitations & $\begin{array}{l}\text { Whole animal model. Good concordance with mammalian and in vitro } \\
\text { results for chemicals with direct action on the thyroid gland, poor } \\
\text { concordance for chemicals with indirect action on thyroid. High } \\
\text { variability, but improving. Good model for aqueous solutions, but } \\
\text { some large molecules may not be able to pass the chorion during the } \\
\text { first } 3 \text { days of the embryo development. Low throughput. Utility } \\
\text { limited as thyroid endpoints evaluated are limited. }\end{array}$ \\
\hline 6. Documentation & $\begin{array}{l}\text { Raldua and Babin, 2009; Thienpont et al. 2011; Henn \& Braunbeck } \\
\text { 2011; Kais et al. } 2013\end{array}$ \\
\hline
\end{tabular}




\section{Thyroid Gland Explant Culture}

82. Overview: The thyroid gland explant cultures provide an assay system in which the ability of chemicals to affect thyroid hormone synthesis and release can be assessed at the level of the whole gland. The assay uses thyroid glands dissected from pro-metamorphic Xenopus laevis tadpoles to determine the potential for xenobiotic chemicals to act directly on the thyroid to inhibit T4 release (Hornung et al. 2012). It measures the release of hormone as an apical endpoint of thyroid gland function and may reflect the effects on any number of molecular initiating events in the thyroid gland that lead to reduced T4 release. The model chemicals used to develop this ex vivo assay targeted two separate cellular functions necessary for thyroid synthesis; namely thyroid peroxidase activity and iodide uptake. A list of other potential molecular targets that could lead to decreased glandular T4 synthesis and/or release could be evaluated, including inhibition of proper TSH signalling and cellular processing events that modulate T4 release. So although the assay may reflect the potential for a chemical to alter the ability of the thyroid gland to release T4, the specific mechanism(s) by which this is produced are not identified.

83. To perform the assay, tadpole thyroid glands are cultured in 96-well plates in media containing TSH to stimulate synthesis and release of T4 that is measured by RIA. This assay can be used in conjunction with other in vitro assays in which chemicals are tested for their potential to inhibit thyroid hormone synthesis. For example, chemicals that are found to inhibit TPO activity in vitro should also inhibit T4 synthesis and subsequent release in the cultured thyroid glands. Thus the explant culture system could be used to verify that the effect of a chemical on a specific molecular initiating event (e.g. TPO inhibition) in vitro is translated to a higher level of biological organization.

84. One concern with this assay is it time requirement owing in part to variability in responses due to differences in endogenous levels of thyroid hormone in the glands from different animals. To detect the decreased T4 release from the glands, stimulation by TSH over several days is required to decrease the level of stored thyroid hormone. Because T4 released from the X. laevis thyroid gland is presumably a combination of newly synthesized hormone and stored hormone, the amount of stored T4 contributing to the total amount released must be decreased to permit detection of a change in newly synthesized T4. Thus this assay is a relatively low throughput assay in which the glands are cultured over 8 -d and the $\mathrm{T} 4$ released over the final $48 \mathrm{~h}$ in culture.

85. An additional concern is the reliance on an inhibition endpoint, is that reduced T4 release could also be associated with general stress in the cultured glands. For chemicals that are very potent TH synthesis inhibitors and show no overt toxicity to the gland, the assay works well as a tool to verify the activity of the chemical in vitro. For chemicals that inhibit T4 release but also produce toxicity in the glands, it may be difficult to confirm that the inhibition of thyroid hormone release is due to specific inhibition of the thyroid hormone synthesis and release pathway and not due to toxicity. Integrating measures of cytotoxicity with this assay to separate specific thyroid hormone inhibition from general toxicity is currently under investigation.

86. Conclusion: The thyroid explant cultures may provide value in the future as a tool to investigate thyroid-specific signalling events in a low throughput mode. As currently described the assay could be used as a pre-screen for chemicals that could impair the TSH-stimulated T4 release from the thyroid glands without regard to mechanism. However, it is not sufficiently developed to be used alone as a diagnostic screening tool for thyroid hormone synthesis inhibitors, iodide uptake inhibitors, or chemicals acting via other specific molecular initiating events. 
RANKING PARAMETER ANALYSIS

\begin{tabular}{|l|l|}
\hline THYROID GLAND EXPLANT CULTURE ASSAY \\
\hline 1. Biological Plausibility & $\begin{array}{l}\text { Moderate. This assay measures the release of hormone which is an } \\
\text { apical endpoint of thyroid gland function. As such this endpoint can } \\
\text { reflect the effects on any number of molecular initiating events in the } \\
\text { thyroid gland that would lead to reduced T4 release. }\end{array}$ \\
\hline $\begin{array}{l}\text { 2. Extrapolation to } \\
\text { humans, or broadly } \\
\text { applicable across } \\
\text { vertebrates/phyla }\end{array}$ & $\begin{array}{l}\text { Strong. The conserved nature of pathways for thyroid hormone } \\
\text { synthesis and release would indicate that the responses within the } \\
\text { isolated thyroid gland culture could be readily extrapolated across } \\
\text { other vertebrates. }\end{array}$ \\
\hline $\begin{array}{l}\text { 3. Availability of } \\
\text { Resources }\end{array}$ & $\begin{array}{l}\text { Moderate Assay can be performed readily where X. laevis cultures } \\
\text { are available but dissection and availability of tadpole thyroid glands is } \\
\text { a limitation. Detection of the T4 released by the glands is done via } \\
\text { commercially available canine T4 RIA kit using radioactive 125-I } \\
\text { labelled T4. }\end{array}$ \\
\hline 4. Reference Chemicals & $\begin{array}{l}\text { Moderate-Strong. The assay was developed using three model thyroid } \\
\text { synthesis inhibitors, MMI, PTU, perchlorate that act by either } \\
\text { inhibiting TPO or inhibiting iodide uptake into the gland. MMI used } \\
\text { as a positive control and gives a response curve that spans the range } \\
\text { starting near 5 } \mu \mathrm{M} \text { to full inhibition of T4 release at 50 } \mu \text { M. This assay } \\
\text { has also detected inhibition of release by industrial chemicals } \\
\text { (unpublished). }\end{array}$ \\
\hline 5. Assay Features/ & $\begin{array}{l}\text { Integrated assay for thyroid-specific signalling events. Low } \\
\text { throughput. Minimal number of chemicals tested. High variability } \\
\text { basal release among glands. Access to tadpoles and difficulty } \\
\text { dissecting thyroid gland are limitations. General toxicity assay needs to } \\
\text { be incorporated. }\end{array}$ \\
\hline Hornung et al., 2012 \\
\hline 6. Documentation
\end{tabular}




\section{EVALUATION OF BLOCK \#8 ASSAYS - INTEGRATIVE CELLULAR ASSAYS}

87. The block encompasses assays that target assessment of the effects of xenobiotics on cellular proliferation and differentiation that is regulated by the activation of the $\mathrm{TH}$ nuclear receptors. The block encompasses 3 assay types. T-screen assays that evaluate cell proliferation of rat pituitary tumour-cell line (GH3) were analysed. Assays probing migration and differentiation of human neural progenitor cells (hNPC) in response to TH nuclear receptor activation were also assessed. Both were found to be at low level of readiness for inclusion in the OECD Test Guideline programme. Analysis of TSH-responsive cell proliferation assay was not possible due to the lack of publicly available information.

\begin{tabular}{|c|c|c|}
\hline $\begin{array}{c}\text { T-Screen (TR } \\
\text { induced } \\
\text { proliferation assay }\end{array}$ & $\begin{array}{c}\text { Human neural } \\
\text { progenitor cell }\end{array}$ & $\begin{array}{c}\text { TSH induced } \\
\text { proliferation assay }\end{array}$ \\
\hline C & C & Not analysed \\
\hline
\end{tabular}




\section{T-Screen - TR Induced Proliferation Assay}

88. Overview: The T-screen assay is a proliferation assay based on the growth of rat pituitary GH3 cells, which is a rat pituitary tumour cell line. The cell growth is dependent on the T3 and the cells have a high expression of thyroid hormone receptors (TRs). The growth stimulatory effect of T3 is mediated by well characterized specific, high-affinity TRs that upon binding of thyroid hormone (TH) bind to thyroid hormone responsive elements (TREs) in the cell nucleus ultimately leading to gene expression. The T-Screen assay can be used for the detection of agonistic and antagonistic properties of compounds at the level of the thyroid receptor (TR).

89. Conclusion: The T-screen could be applied as a valuable method for screening of compounds for TR-mediated effects. However, the endpoint is a non-specific. Alterations in cell proliferation may arise from any one of a number of mechanisms and as such the assay may be expected to give rise to a number of false positive compounds - i.e., compounds that may interfere with cell proliferation of pituitary cells but through a TH-independent mechanism. There has not been sufficient testing performed to estimate the degree of false positives that may result from this assay. It also has a major drawback, as most thyroid EAS/EDs do not interact with the receptor but interfere with the transport or synthesis of T3 and T4 (Jacobs et al 2013). Furthermore, if the T-Screen assay is to be validated with the aim of becoming an OECD Test Guideline method, the assay method would have to undergo alignment and optimization.

\section{RANKING PARAMETER ANALYSIS}

\begin{tabular}{|l|l|}
\hline T - SCREEN PROLIFERATION ASSAY \\
\hline 1. Biological Plausibility & $\begin{array}{l}\text { Moderate-Strong. Thyroid hormone induces cell proliferation by } \\
\text { activating thyroid hormone receptors (TR). This assay detects agonistic } \\
\text { and antagonistic properties of compounds on proliferation. }\end{array}$ \\
\hline $\begin{array}{l}\text { 2. Extrapolation to } \\
\text { humans, or broadly } \\
\text { applicable across } \\
\text { vertebrates/phyla }\end{array}$ & $\begin{array}{l}\text { Strong. Assay used to effects at the level of the TR. As the TRs are } \\
\text { highly conserved between various vertebrate species, the assay is } \\
\text { expected to be broadly applicable across species including humans. }\end{array}$ \\
\hline $\begin{array}{l}\text { 3. Availability of } \\
\text { Resources }\end{array}$ & $\begin{array}{l}\text { Strong. Expertise and technology required for the performance of the } \\
\text { assay is easily acquired. }\end{array}$ \\
\hline 4. Reference Chemicals & $\begin{array}{l}\text { Moderate. T3 is used as a positive control. Various industrial and } \\
\text { commercial compounds tested include PCBs, phthalates, brominated } \\
\text { diphenylethers, and pesticides. }\end{array}$ \\
\hline $\begin{array}{l}\text { 5. Assay Features/ } \\
\text { Limitations }\end{array}$ & $\begin{array}{l}\text { Rat pituitary cell proliferation assessed in presence and absence of T3. } \\
\text { Effects of chemicals are reproducible within same lab. Effects may } \\
\text { arise from a number of non-thyroid mediated effects. Few } \\
\text { environmental chemical produce their effects by interacting at the level } \\
\text { of the thyroid receptor. }\end{array}$ \\
\hline 6. Documentation & Long et al., 2012; Ghisari and Bonefeld-Jorgensen, 2005 \\
\hline
\end{tabular}




\section{Human Neural Progenitor Cell Proliferation/Differentiation/Migration}

90. Overview: One of the primary concerns for thyroid hormone disruption is the effect that either too much or too little hormone will negatively impact brain development. A three-dimensional cell aggregate system known as a 'neurosphere' has been proposed as a screening tool to identify developmental neurotoxicants. This assay encompasses growth of normal human neural progenitor cells (hNPC) cultured as free-floating neurospheres in proliferation medium and plating onto a poly$\mathrm{D}$-lysine/laminin matrix. Assessment of cell viability, proliferation, migration, and differentiation is conducted following a 1-2-week preincubation period with test compounds. NPCs grown as neurospheres appear to mimic the fundamental processes of brain development including two thyroiddependent processes, cell migration and oligodentrocyte differentiation. Individual spheres in single wells of a 96-well plate proliferate over time and exhibit a zonal distribution of astrocytes in the periphery and a mix of astrocytes and neurons in the centre. This is believed to result from a growth factor gradient from the periphery to the centre of the sphere (Moors et al., 2009). Proliferation is determined by simply measuring sphere size in contrast to negative controls without added mitogens. Cell viability is determined by measuring mitochondrial reductase activity using the AlamarBlue assay. On withdrawal of growth factors and in the presence of an appropriate matrix substrate, cell migration is initiated and cells move from the sphere over the course of several days in a radial and tangential migration pattern. Migration is measured by determining the distance from the edge of the sphere to the furthest migrated cells 48 -hours after initiation at four defined positions on the sphere.

91. The molecular signals controlling migration in neurospheres are not yet known, but T3 added to the medium can initiate and facilitate this behaviour (Moors et al., 2009; Fritsche et al., 2005; Schreiber et al., 2010). Oligodendrocyte precursor cells are present in the migration area outside of the sphere indicative of morphologic maturation with the passage of time, and the number of oligodendrocytes is increased in the presence of T3 (Moors et al., 2009; Schreiber et al., 2010; Fritsche et al., 2005). Based on these in vivo and in vitro data, both of these developmental processes are known to require thyroid hormone. Fritsche and colleagues have utilized this assay system to investigate the thyroid-hormone-dependent neurotoxicity associated with PCBs and PBDEs (Fritsche et al., 2005; Schreiber et al., 2010). No effect was seen on hNPC proliferation with these compounds, but PCB 118 but not PCB126 increased the differentiation of cells into oligodendrocytes, an effect that was mimicked by T3 and blocked by the TR blocker NH3. The effects of PCB126 to decrease cell migration were similar to those observed with PBDEs the TR blocker, NH3.

92. Although a number of studies have demonstrated that the 3D neurosphere model is able to react to exposure to a variety of developmental neurotoxicants, studies designed to systematically test the predictive power of neurospheres for toxicity screenings have not been performed. Neither is it possible to conclude that effects identified in this assay system occur because of thyroid disruption.

93. Conclusion: The development of screening assays for thyroid-mediated developmental neurotoxicity using neurospheres is too nonspecific to be useful as an assay system for a direct thyroid target. This assay system may be useful for more general developmental neurotoxicity screening efforts, some for which may be mediated directly or indirectly by thyroid effects. Only a limited number of chemicals that have been assessed and the assay time and labour intensive. Ethical issues in addition to concerns about availability of tissue for routine screening assessments may limit applicability of this assay. A direct sensitivity assessment between human and rodent NPC models has not been conducted, but it is possible that rodent models may circumvent this shortcoming. Based on this assessment, this assay falls within Level C. 
RANKING PARAMETER ANALYSIS

\begin{tabular}{|l|l|}
\hline HumanNPC NEUROSPHERES ASSAYS \\
\hline 1. Biological Plausibility & $\begin{array}{l}\text { Moderate. Thyroid hormone disruption can interfere with neuronal cell } \\
\text { migration and differentiation and lead to neurodevelopmental } \\
\text { impairments. Xenobiotics may interfere with these processes via a } \\
\text { number of means, one of which is thyroid hormone disruption. }\end{array}$ \\
$\begin{array}{l}\text { 2. Extrapolation to } \\
\text { humans, or broadly } \\
\text { applicable across } \\
\text { vertebrates/phyla } \\
\text { 3. Availability of } \\
\text { Resources }\end{array}$ & $\begin{array}{l}\text { Moderate-High. Developed with human NPC. The applicability of } \\
\text { the responses profiled in this assay to a broad spectrum of ecologically- } \\
\text { important species has not been ascertained. }\end{array}$ \\
$\begin{array}{l}\text { 4. Reference Chemicals } \\
\text { Weak-Moderate. Accessibility of hNPCs of same embryonic age may } \\
\text { be an issue. There may also be ethical concerns. }\end{array}$ \\
$\begin{array}{l}\text { Weak. Only a few chemicals. Some are potential thyroid hormone } \\
\text { disruptors (PCBs, PBDEs, endosulfan) Chemicals from similar classes } \\
\text { have distinct profiles (eg, PCB 118 vs PCB126; PCBs vs PBDEs). A } \\
\text { number of non-thyroid active chemicals are positive in this assay as } \\
\text { they also impair brain development. Positive controls include T3 in the } \\
\text { two publications considered (3nM and 30nM) and the TR blocker NH3 } \\
\text { (10nM and luM). }\end{array}$ \\
\hline Features/Limitations. & $\begin{array}{l}\text { Integrated assay with many readouts important in brain development. } \\
\text { Readout of assay is not specific to thyroid disruption. Very low } \\
\text { throughput. Limited information on sensitivity and only small number } \\
\text { of chemicals tested. Concern for availability of tissue, cytotoxicity } \\
\text { assays on a large scale may not be possible. Ethical concerns may arise } \\
\text { from use of hNPCs. }\end{array}$ \\
\hline 6. Documentation & Fritsche et al. 2011; Schreiber et al., 2010; 2010; Moors et al, 2009. \\
\hline
\end{tabular}




\section{OVERALL CONCLUSIONS}

94. In summary, a suite of in vitro methodologies probing a range of potential target sites for disruption of thyroid signalling was examined by the TSEG. As summarized in Table 1 at the beginning of this document, 18 candidate assay systems were categorized for their 'state of readiness' for validation in the short-(A), intermediate (B), or long-term $(\mathrm{C})$ based on predefined parameters. In addition to the state of readiness, assays were further scrutinized by the TSEG for the toxicological relevance of the target site, chemical space interrogated by the assay, and the availability of suitable reference chemicals. This analysis conducted by the TSEG and also reviewed and agreed by the VMG-NA, demonstrated that a number of in vitro assays are available targeting critical aspects of thyroid signalling.

95. Two types of assays are available that are at advanced level of development and could be considered for inclusion in the OECD Test Guideline programme: the thyroperoxidase (TPO) inhibition assays that target thyroid hormone synthesis, and the thyroxin-binding globulin (TBG) and transthyretin (TTR) binding assays that can address thyroid hormone transport to issues and the level of free hormone available for interaction with target cells (Table 1.4 and indicated in Red in Figure 8).

Figure 8: Summary of in vitro and ex vivo assays at high and moderate level of readiness and their targets in the thyroid signalling system.

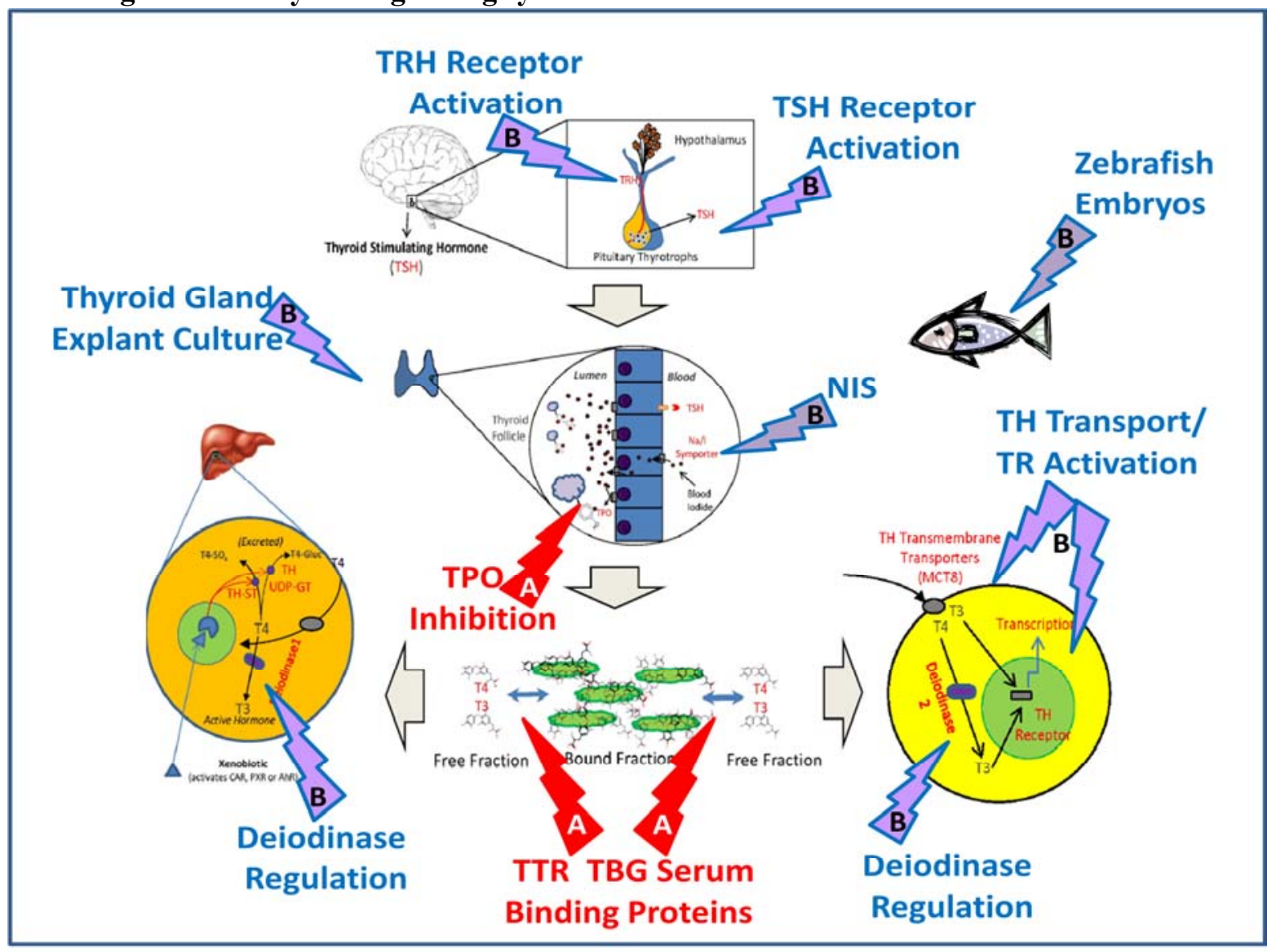

Target site where chemicals may interact to interfere with thyroid hormone signalling. Three assays were identified as in a sufficient state of readiness and as such are recommended as priority candidates for validation. These 'A' assays, targeting TH synthesis through inhibition of TPO, and the binding of hormones to the serum proteins TBG and TTR, are indicated in red A number of other assays were identified that are not at a sufficient 
level of development at the present time, but are targeting critical sites of xenobiotic interaction. These 'B' level assays are recommended for further consideration and development and are indicated in purple.

Table 1.4: Level A Assays Recommended for Validation in the Short-Term

\begin{tabular}{|c|ll|lr|}
\hline $\begin{array}{c}\text { Assa } \\
\text { Nam } \\
\text { e }\end{array}$ & \multicolumn{1}{|c|}{$\begin{array}{c}\text { Assay Block- } \\
\text { Biological Substrate }\end{array}$} & \multicolumn{2}{|c|}{$\begin{array}{c}\text { TSEG } \\
\text { Recommendation }\end{array}$} \\
\hline TPO & 2-TH Synthesis & $\begin{array}{l}\text { Candidate } \\
\text { Validation }\end{array}$ & for \\
\hline TTR & $\begin{array}{l}\text { 3-Serum } \\
\text { Protein }\end{array}$ & Binding & $\begin{array}{l}\text { Candidate } \\
\text { Validation }\end{array}$ & for \\
\hline TBG & $\begin{array}{l}\text { 3-Serum } \\
\text { Protein }\end{array}$ & Binding & $\begin{array}{l}\text { Candidate } \\
\text { Validation }\end{array}$ & for \\
\hline
\end{tabular}

96. A second block of seven assays was identified by the TSEG as being at a B level of readiness and/or as high priority for further research and development (Table 1.5 and indicated in purple in Figure 8). These included assays that probe central regulation at the level of the pituitary and thyroid glands, activation of iodine uptake into the thyroid gland, metabolism of TH via deiodination, and development of a combined transporter/TR transactivation assay. In addition, two higher level assays integrating multiple MOAs were flagged as promising as with further development, they could be useful in a screening context.

Table 1.5: Level B Assays of High Priority for Further Development in the Intermediate Term

\begin{tabular}{|l|l|l|}
\hline Assay Name & \multicolumn{1}{|c|}{$\begin{array}{c}\text { Assay Block - } \\
\text { Biological } \\
\text { Substrate }\end{array}$} & \multicolumn{1}{c|}{ Limitations/Recommendations } \\
\hline $\begin{array}{l}\text { TRH Receptor - } \\
\text { Pituitary }\end{array}$ & $\begin{array}{l}\text { 1-Central } \\
\text { Regulation }\end{array}$ & $\begin{array}{l}\text { Of high interest as critical sites for HPT regulation } \\
\text { yet very few chemicals tested. Assay development } \\
\text { is needed that will account for rapid receptor } \\
\text { internalization and downregulation of these } \\
\text { receptor types. }\end{array}$ \\
\hline Nhyroid Activation - & $\begin{array}{l}\text { 1-Central } \\
\text { Regulation }\end{array}$ & $\begin{array}{l}\text { 2-TH Synthesis } \\
\text { Available assays have only tested a few chemicals. }\end{array}$ \\
\hline $\begin{array}{l}\text { Deiodinase Up- } \\
\text { Down- } \\
\text { Regulation }\end{array}$ & 4-Metabolism & $\begin{array}{l}\text { Of high interest as critical site of action of } \\
\text { chemicals. These assays are currently limited by } \\
\text { the availability of D2 and D3 deiodinases. }\end{array}$ \\
\hline $\begin{array}{l}\text { MCT8/TR } \\
\text { Transactivation }\end{array}$ & $\begin{array}{l}\text { TR Activation assays in 'A' state of readiness but } \\
\text { of limited utility due to lack of action of } \\
\text { Concentration } \\
\text { xenobiotics at the TR. Recommend coupling TR } \\
\text { transfected cell line with MCT8 transporter to } \\
\text { provide information on two potential target sites of } \\
\text { TH disruptors in a single assay. }\end{array}$ \\
\hline $\begin{array}{l}\text { Thyroid Gland } \\
\text { Explant }\end{array}$ & $\begin{array}{l}\text { 7-Assays } \\
\text { Integrating } \\
\text { Multiple MOAs }\end{array}$ & $\begin{array}{l}\text { High interest as important target and assay probes } \\
\text { integrated functionality of thyroid gland. High } \\
\text { variability and insufficient cytotoxicity controls }\end{array}$ \\
\hline
\end{tabular}




\begin{tabular}{|l|l|l|}
\hline & \multicolumn{1}{|c|}{ Assays } & limit current utility. \\
\hline Zebrafish & $\begin{array}{l}\text { Whole organism system so fills critical gap to } \\
\text { Integrating } \\
\text { Multiple MOAs }\end{array}$ & \begin{tabular}{l} 
probe multiple MOAs. \\
\hline
\end{tabular}
\end{tabular}

97. In combination these in vitro and ex vivo assays can be very useful tools for screening and assessment of potential toxicants to the thyroid signalling system. 


\section{REFERENCES}

Abe, H. et al. (2004), "Thyrotropin-releasing hormone-stimulated thyrotropin expression involves islet-brain-1/c-Jun N-terminal kinase interacting protein-1", Endocrinology, Vol. 145, No. 12, pp. 5623-8.

Aranda, A. and A. Pascual (2001), "Nuclear hormone receptors and gene expression", Physiological Reviews, Vol. 81, No. 3, pp. 1269-1304.

Atterwill, C.K. and K.F. Fowler (1990), "A comparison of cultured rat FRTL-5 and porcine thyroid cells for predicting the thyroid toxicity of xenobiotics", Toxicology in Vitro, Vol. 4, No. 4-5, pp. 36974.

Bernal, J. (2002), "Action of thyroid hormone in brain", Journal of Endocrinological Investigation, Vol. 25, No. 3, pp. 268-88.

Bianco, A.C. et al. (2002), "Biochemistry, cellular and molecular biology, and physiological roles of the iodothyronine selenodeiodinases", Endocrine Reviews, Vol. 23, No. 1, pp. 38-89.

Boutin, A. et al. (2011), "Thyrotropin receptor stimulates internalization-independent persistent phosphoinositide signalling", Molecular Pharmacology, Vol. 80, No. 2, pp. 240-6.

Braun, D. et al. (2012), "Tyrosine kinase inhibitors noncompetitively inhibit MCT8-mediated iodothyronine transport", The Journal of Clinical Endocrinology \& Metabolism, Vol. 97, No. 1, pp. E100-5.

Brouwer, A. et al. (1998), "Interactions of persistent environmental organohalogens with the thyroid hormone system: mechanisms and possible consequences for animal and human health", Toxicology and Industrial Health, Vol. 14, No. 1-2, pp. 59-84.

Brouwer, A. (1991), "Role of biotransformation in PCB-induced alterations in vitamin A and thyroid hormone metabolism in laboratory and wildlife species", Biochem. Soc. Trans., Vol. 19, No. 3, pp. $731-7$.

Brouwer, A. and K.J. van den Berg (1986), "Binding of a metabolite of 3,4,3',4'-tetrachlorobiphenyl to transthyretin reduces serum vitamin A by inhibiting the formation of the protein complex carrying both retinol and thyroxin", Toxicology and Applied Pharmacology, Vol. 85, No. 3, pp. 301-312.

Butt, C.M., D. Wang and H.M. Stapleton (2011), "Halogenated phenolic contaminants inhibit the in vitro activity of the thyroid-regulating deiodinases in human liver", Toxicological Sciences, Vol. 124, No. 2, pp. 339-47.

Capen, C. C. (1998), "Correlation of mechanistic data and histopathology in the evaluation of selected toxic endpoints of the endocrine system", Toxicology Letters, Vol. 102, No. 103, pp.405-409.

Chang, H. C. and D. R. Doerge (2000). "Dietary genistein inactivates rat thyroid peroxidase in vivo without an apparent hypothyroid effect", Toxicology and Applied Pharmacology, Vol. 168, No. 3, pp. 244-252. 
Chauhan, K.R., P.R. Kodavanti and J.D. McKinney (2000), "Assessing the role of ortho-substitution on polychlorinated biphenyl binding to transthyretin, a thyroxine transport protein", Toxicology and Applied Pharmacology, Vol. 162, No. 1, pp. 10-21.

Cheek, A.O. et al. (1999), "Potential mechanisms of thyroid disruption in humans: interaction of organochlorine compounds with thyroid receptor, transthyretin, and thyroid-binding globulin", Environmental Health Perspective, Vol. 107, No. 4, pp. 273-278.

Chopra, I.J. et al. (1974), "Alterations in circulating thyroid hormones and thyrotropin in hepatic cirrhosis: evidence for euthyroidism despite subnormal serum triiodothyronine", The Journal of Clinical Endocrinology \& Metabolism, Vol. 39, No. 3, pp. 501-11.

Coady, K. et al. (2010), "Evaluation of the amphibian metamorphosis assay: exposure to the goitrogen methimazole and the endogenous thyroid hormone L-thyroxine", Environmental Toxicology and Chemistry, Vol. 29, No. 4, pp.869-880.

Cohen, R.N., F.E. Wondisford and A.N. Hollenberg (1998), "Two separate NCoR (nuclear receptor corepressor) interaction domains mediate corepressor action on thyroid hormone response elements", Molecular Endocrinology, Vol. 12, No. 10, pp. 1567-81.

Cooper, D. S. (2005), “Antithyroid drugs”, The New England Journal of Medicine, Vol. 352,

pp. 905-917.

Crantz, F.R., J.E. Silva and P.R. Larsen (1982), "An analysis of the sources and quantity of 3,5,3'triiodothyronine specifically bound to nuclear receptors in rat cerebral cortex and cerebellum", Endocrinology, Vol. 110, No. 2, pp. 367-75.

Crofton, K. M. (2008), "Thyroid disrupting chemicals: mechanisms and mixtures", International Journal of Andrology, Vol. 31, No. 2, pp. 209-223.

Crofton et al. (2011) Developmental Neurotoxicity Testing: Recommendations for Developing Alternative Methods for the Screening and Prioritization of Chemicals, Altex, Vol. 28 No. , pp. 9-15).

Cunha Lima, S.T. et al. (2009), Differential effects of TR ligands on hormone dissociation rates: Evidence for multiple ligand entry/exit pathways", The Journal of Steroid Biochemistry and Molecular Biology, Vol. 117, No. 4-5, pp. 125-131.

Czarnocka, B. (2011), "Thyroperoxidase, thyroglobulin, $\mathrm{Na}(+) / \mathrm{I}(-)$ symporter, pendrin in thyroid autoimmunity", Frontiers in bioscience: A virtual library of medicine, Vol. 16, pp. 783-802.

Decherf, S. et al. (2010a), "Disruption of thyroid hormone-dependent hypothalamic set-points by environmental contaminants", Molecular and Cellular Endocrinology, Vol. 323, No. 2, pp. 172-82.

Decherf, S. et al. (2010b), "Thyroid hormone exerts negative feedback on hypothalamic type 4 melanocortin receptor expression", Proceedingsof the National Academy of Sciences, Vol. 107, No 9, USA, pp. 4471-6.

DeVito, M. et al. (1999), "Screening methods for thyroid hormone disruptors", Environmental Health Perspectives, Vol. 107, No. 5, pp. 407-415.

Divi, R. L. and D. R. Doerge (1994), "Mechanism-based inactivation of lactoperoxidase and thyroid peroxidase by resorcinol derivatives", Biochemistry, Vol. 33, No. 32, pp. 9668-9674. 
Divi, R. L., H. C. Chang and D. R. Doerge (1997), "Anti-thyroid isoflavones from soybean: isolation, characterization, and mechanisms of action", Biochem Pharmacol, Vol. 54, No. 10, pp. 1087-1096.

Doerge, D. R. and W. P. Niemczura (1989), "Suicide inactivation of lactoperoxidase by 3-amino1,2,4-triazole", Chemical Research in Toxicology, Vol. 2, No. 2, pp. 100-103.

Doerge, D. R. and C. J. Decker (1994), "Inhibition of peroxidase-catalyzed reactions by arylamines: mechanism for the anti-thyroid action of sulfamethazine", Chemical Research in Toxicology, Vol. 7, No. 2, pp. 164-169.

Doerge, D. R. et al. (1998), "Mechanism for inhibition of thyroid peroxidase by leucomalachite green", Chemical Research in Toxicology, Vol. 11, No. 9, pp. 1098-1104.

Doerge, D. R. and H. C. Chang (2002a), "Inactivation of thyroid peroxidase by soy isoflavones, in vitro and in vivo", Journal of Chromatography. B, Analytical Technologies in the Biomedical and Life Sciences, Vol. 777, No. 1-2, 269-279.

Doerge, D. R. and D. M. Sheehan (2002b), "Goitrogenic and estrogenic activity of soy isoflavones", Environmental Health Perspectives, Vol. 110, No. 3, pp. 349-353.

Dudek KM, Suter L, Darras VM, Marczylo EL, Gant TW (2013) Decreased translation of Dio3 mRNA is associated with drug-induced hepatotoxicity. Biochem J. 453(1):71-82

Dumitrescu, A. M. et al. (2004), "A novel syndrome combining thyroid and neurological abnormalities is associated with mutations in a monocarboxylate transporter gene", American Journal of Human Genetics, Vol. 74, No. 1, pp. 168-75.

Dumitrescu, A. M. et al. (2006), "Tissue-specific thyroid hormone deprivation and excess in monocarboxylate transporter (mct) 8-deficient mice", Endocrinology, Vol. 147, No. 9, pp. 4036-4043.

EFSA 2013 Scientific Opinion on the identification of pesticides to be included in cumulative assessment groups on the basis of their toxicological profile. EFSA Journal 2013;11(7):3293 [131 pp.]. doi:10.2903/j.efsa.2013.3293 EFSA Panel on Plant Protection Products and their Residues (PPR). Appendix F.1. Data collection for thyroid toxicity- EFSA Part 1 Appendix F.2. Data collection thyroid toxicity EFSA Part 2. http://www.efsa.europa.eu/en/efsajournal/pub/3293.htm (accessed 18/2/2014)

Emiliano, A. B. et al. (2010), "Shifts in propylthiouracil and methimazole prescribing practices: antithyroid drug use in the United States from 1991 to 2008", The Journal of Clinical Endocrinology \& Metabolism," Vol. 95, No. 5, pp. 2227-2233.

Fekete, C. and R.M. Lechan (2007), "Negative feedback regulation of hypophysiotropic thyrotropinreleasing hormone (TRH) synthesizing neurons: role of neuronal afferents and type 2 deiodinase", Front Neuroendocrinol, Vol. 28, No. 2-3, pp. 97-114.

Fekete, C. and R.M. Lechen (2013), "Central Regulation of Hypothalamic- Pituitary-Thyroid Axis Under Physiological and Pathophysiological Conditions", Endocrine Reviews December, p.1087.

Flippin, J. L. et al. (2009), "Predictive modeling of a mixture of thyroid hormone disrupting chemicals that affect production and clearance of thyroxine", International Journal of Toxicology, Vol. 28, No. 5, pp. 368-381.

Fini, J. B. et al. (2012), "Thyroid hormone signaling in the Xenopus laevis embryo is functional and susceptible to endocrine disruption", Endocrinology, Vol. 153, No. 10, pp. 5068-5081. 
Flynn, T.R. et al. (1994), "A novel C-terminal domain in the thyroid hormone receptor selectively mediates thyroid hormone inhibition", The Journal of Biology Chemistry, Vol. 269, No. 52, pp. 32713-6.

Fortunato, R. S. et al. (2010), "Functional consequences of dual oxidase-thyroperoxidase interaction at the plasma membrane", The Journal of Clinical Endocrinology \& Metabolism, Vol. 95, No. 12, pp. 5403-5411.

Freitas, J. et al. (2011), "Detection of thyroid hormone receptors by a novel stable in vitro reporter gene assay", Toxicology In Vitro, Vol. 25, No. 1, pp. 257-266.

Freyberger, A. and H. J. Ahr (2006), "Studies on the goitrogenic mechanism of action of N,N,N',N'tetramethylthiourea", Toxicology, Vol. 217, No. 2-3, pp. 169-175.

Friesema, E. C. et al. (2004), "Association between mutations in a thyroid hormone transporter and severe X-linked psychomotor retardation”, The Lancet, Vol. 364, No. 9443, pp. 1435-7.

Friesema, E. C. et al. (2008), "Effective cellular uptake and efflux of thyroid hormone by human monocarboxylate transporter 10", Molecular Endocrinology, Vol. 22, No. 6, pp. 1357-69.

Fritsche, E., K. Gassmann and T. Schreiber (2011), "Neurospheres as a model for developmental neurotoxicity testing", Methods in Molecular Biology, Vol. 758, pp. 99-114.

Furtmuller, P. G. et al. (2006), "Active site structure and catalytic mechanisms of human peroxidases", Archives of Biochemistry and Biophysics, Vol. 445, No. 2, pp. 199-213.

Galton, V.A. et al. (1999), "Pregnant rat uterus expresses high levels of the type 3 iodothyronine deiodinase", Journal of Clinical Investigation, Vol. 103, No. 7, pp. 979-87.

Gauger, K.J. et al. (2007), "Polychlorinated biphenyls 105 and 118 form thyroid hormone receptor agonists after cytochrome P4501A1 activation in rat pituitary GH3 cells", Environmental Health Perspectives, Vol. 115, No. 11, pp. 1623-30.

Ghisari, M. and E.C. Bonefeld-Jorgensen (2009), "Effects of plasticizers and their mixtures on estrogen receptor and thyroid hormone functions", Toxicology Letters, Vol. 189, No. 1, pp. 67-77.

Ghisari, M. and E.C. Bonefeld-Jorgensen (2005), "Impact of environmental chemicals on the thyroid hormone function in pituitary rat GH3 cells", Molecular and Cellular Endocrinology, Vol. 244, No. 1-2, pp. 31-41.

Gilbert, M.E.and R.T. Zoeller (2010). Thyroid hormone-impact on the developing brain: Possible mechanisms of neurotoxicity. Neurotoxicology, 3d Edition, Target Organ Toxicology Series (Harry GH and Tilson HA, eds.) New York: Informa Healthcare USA, Inc, pp. 79-111.

Grommen, S. V. et al. (2011), "Ontogenic expression profiles of thyroid-specific genes in embryonic and hatching chicks", Domestic Animal Endocrinology, Vol. 40, No. 1, pp. 10-18.

Guissouma, H. et al. (1998), "Physiological regulation of hypothalamic TRH transcription in vivo is T3 receptor isoform specific", FASEB Journal, Vol. 12, No. 15, pp. 1755-64. 
Hallgren, S. and P.O. Darnerud (2002), "Polybrominated diphenyl ethers (PBDEs), polychlorinated biphenyls (PCBs) and chlorinated paraffins (CPs) in rats-testing interactions and mechanisms for thyroid hormone effects", Toxicology, Vol. 177, No. 2-3, pp. 227-243.

Hamers, T. et al. (2008). "Biotransformation of brominated flame retardants into potentially endocrine-disrupting metabolites, with special attention to 2,2',4,4'-tetrabromodiphenyl ether (BDE47)", Molecular Nutrition \& Food Research, Vol. 52, No. 2, pp. 284-298.

Heldin, N.E. et al. (1994), "Thyrotropin (TSH)-induced receptor internalization in nonthyroidal cells transfected with a human TSH-receptor complementary deoxyribonucleic acid", Endocrinology, Vol. 134, No. 5 pp. 2032-6.

Henn, K. and T. Braunbeck (2011), "Dechorionation as a tool to improve the fish embryo toxicity test (FET) with the zebrafish (Danio rerio)", Comparative Biochemistry and Physiology Part C: Toxicology \& Pharmacology, Vol. 153, No. 1, pp. 97-8.

Hennemann, G. and T.J. Visser (1997), "Thyroid hormone synthesis, plasma membrane transport and metabolism", in Grossman A (ed) Handbook of Experimental Pharmacology, Springer, Berlin, pp. 75117.

Hennemann, G. et al. (2001), "Plasma membrane transport of thyroid hormones and its role in thyroid hormone metabolism and bioavailability", Endocrine Reviews, Vol. 22, No. 4, pp. 451-76.

Heuer, H. and T.J. Visser (2009), "Minireview: Pathophysiological importance of thyroid hormone transporters", Endocrinology, Vol. 150, No. 3, pp. 1078-83.

Hinkle, P.M., D.G. Lewis and T.L. Greer (1980), "Thyrotropin-releasing hormone-receptor interaction in GH3 pituitary cells", Endocrinology, Vol. 106, No. 3, pp. 1000-5.

Hinkle, P.M., A.U. Gehret and B.W. Jones (2012), "Desensitization, trafficking, and resensitization of the pituitary thyrotropin-releasing hormone receptor", Frontiers in Neuroscience, Vol. 6, p. 180.

Hofmann, P.J., L. Schomburg and J. Kohrle (2009), "Interference of endocrine disrupters with thyroid hormone receptor-dependent transactivation", Toxicological Sciences, Vol. 110, No. 1, pp. 125-137.

Hollenberg, A.N., T. Monden and F.E. Wondisford (1995), "Ligand-independent and -dependent functions of thyroid hormone receptor isoforms depend upon their distinct amino termini", The Journal of Biology Chemistry, Vol. 270, No. 24, pp. 14274-80.

Hollenberg, A.N. (2008), "The role of the thyrotropin-releasing hormone (TRH) neuron as a metabolic sensor", Thyroid, Vol. 18, No. 2, pp. 131-9.

Hornung, M. W. et al. (2010), "Inhibition of Thyroid Hormone Release from Cultured Amphibian Thyroid Glands by Methimazole, 6-Propylthiouracil, and Perchlorate", Toxicological Sciences, Vol. 118, No. 1, pp. 42-51.

Hosoya, T. (1963), "Effect of various reagents including antithyroid compounds upon the activity of thyroid peroxidase", Journal of Biochemistry, Vol. 53, No. 5, pp. 381-388.

Huang, S.A.et al. (2000), "Severe hypothyroidism caused by type 3 iodothyronine deiodinase in infantile hemangiomas", The New England Journal of Medicine, Vol. 343, pp. 185-9. 
Huang, S.A. et al. (2002), "A 21-year-old woman with consumptive hypothyroidism due to a vascular tumor expressing type 3 iodothyronine deiodinase", Journal of Clinical Endocrinology \& Metabolism, Vol. 87, No. 10, pp. 4457-61.

Hurley, P. M. (1998), "Mode of carcinogenic action of pesticides inducing thyroid follicular cell tumors in rodents", Environmental Health Perspectives, Vol. 106, No. 8, pp. 437-445.

Jacobs, M.N. et al. (2008), "The use of metabolising systems for in vitro testing of endocrine disruptors', Current Drug Metabolism, Vol. 9, No. 8, pp. 796-826.

Jacobs, M.N. et al. (2013), "In vitro metabolism and bioavailability tests for endocrine active substances: what is needed next for regulatory purposes?", ALTEX, Vol. 30, No. 3, pp. 331-51.

Joseph-Bravo, P. et al. (1998), "Multifactorial Modulation of TRH Metabolism", Cellular and Molecular Neurobiology, Vol. 18, No. 2, pp. 1-47.

Jugan, M.L. et al. (2007), "A new bioluminescent cellular assay to measure the transcriptional effects of chemicals that modulate the alpha-1 thyroid hormone receptor", Toxicology In Vitro, Vol. 21, No. 6, pp. 1197-1205.

Kang, K.S. et al. (2001), "Effects and neuro-toxic mechanisms of 2, 2', 4, 4', 5, 5'-hexachlorobiphenyl and endosulfan in neuronal stem cells", The Journal of Veterinary Medical Science, Vol. 63, No. 11, pp. 1183-90.

Kais, B. et al. (2013), "DMSO modifies the permeability of the zebrafish (Danio rerio) chorionImplications for the fish embryo test (FET)", Aquatic Toxicology, Vol. 140-141, pp. 229-38.

Kaufman, K. D. et al. (1989), "Generation of recombinant, enzymatically active human thyroid peroxidase and its recognition by antibodies in the sera of patients with Hashimoto's thyroiditis", The Journal of Clinical Investigation, Vol. 84, No. 2, pp. 394-403.

Kessler, J., C. Obinger and G. Eales (2008), "Factors influencing the study of peroxidase-generated iodine species and implications for thyroglobulin synthesis", Thyroid, Vol. 18, No. 7, pp. 769-774.

Kitamura S. et al. (2005), "Anti-thyroid hormonal activity of tetrabromobisphenol A, a flame retardant, and related compounds: Affinity to the mammalian thyroid hormone receptor, and effect on tadpole metamorphosis", Life Sciences, Vol. 76, No. 14, pp. 1589-1601.

Kohrle, J., R.D. Hesch and J.L. Leonard (1991), "Intracellular pathways of iodothyronine metabolism", in Utiger RD (ed) The Thyroid, Lippincott, Philadelphia, pp. 144-189.

Kragie, L. and D. Doyle (1992), "Benzodiazepines inhibit temperature-dependent L[125I]triiodothyronine accumulation into human liver, human neuroblast, and rat pituitary cell lines", Endocrinology, Vol. 130, No. 3, pp. 1211-6.

Kudo Y. and K. Yamauchi (2005), "In vitro and in vivo analysis of the thyroid disrupting activities of phenolic and phenol compounds in Xenopus laevis", Toxicological Sciences, Vol. Mar;84(1):29-37. Epub 2004 Dec 8.

Lans, M.C. et al. (1994), "Different competition of thyroxine binding to transthyretin and thyroxinebinding globulin by hydroxy-PCBs, PCDDs and PCDFs", European Journal of Pharmacology: Environmental Toxicology and Pharmacology, Vol. 270, No. 2-3, pp. 129-136. 
Larsen P.R. and M.J. Berry (1995), "Nutritional and hormonal regulation of thyroid hormone deiodinases", Annual Review of Nutrition, Vol. 15, pp. 323-52.

Lazar, M. A. and W.W. Chin (1990), "Nuclear thyroid hormone receptors", Journal of Clinical Investigation, Vol. 86, pp. 1777-1782.

Lecat-Guillet, N. et al. (2008), "Small-molecule inhibitors of sodium iodide symporter function", Chembioche, Vol. 9, No. 6, pp. 889-895.

Lezoualc'h, F. et al. (1992), "Assignment of the beta-thyroid hormone receptor to 3,5,3'triiodothyronine-dependent inhibition of transcription from the thyrotropin-releasing hormone promoter in chick hypothalamic neurons", Molecular Endocrinology, Vol. 6, No. 11, pp. 1797-804.

Lim, C. F. et al. (1993), "A furan fatty acid and indoxyl sulfate are the putative inhibitors of thyroxine hepatocyte transport in uremia", Journal of Clinical Endocrinology \& Metabolism, Vol. 76, No. 2, pp. 318-24.

Lim, C. F. et al. (1996), "Drug effects on triiodothyronine uptake by rat anterior pituitary cells in vitro", Experimental and clinical endocrinology \& diabetes: official journal, German Society of Endocrinology [and] German Diabetes Association, Vol. 104, No. 2, pp. 151-7.

Long, M. et al. (2012), "Effects of selected phytoestrogens and their mixtures on the function of the thyroid hormone and the aryl hydrocarbon receptor", Nutrition and Cancer, Vol. 64, No. 7, pp. 100819.

Lindenthal, S. et al. (2009), "Characterization of small-molecule inhibitors of the sodium iodide symporter", Journal of Endocrinology, Vol. 200, No. 3, pp. 357-365.

Magnusson, R. P., A. Taurog and M. L. Dorris (1984), "Mechanisms of thyroid peroxidase- and lactoperoxidase-catalyzed reactions involving iodide", Journal of Biological Chemistry, Vol. 259, No. 22, pp. 13783-13790.

Matsubara, K. et al. (2012), "An improved thyroid hormone reporter assay to determine the thyroid hormone-like activity of amiodarone, bithionol, closantel and rafoxanide", Toxicology Letters, Vol. 208, No. 1, pp. 30-35.

McLachlan, S. M. and B. Rapoport (2007), "Thyroid peroxidase as an autoantigen”, Thyroid, Vol. 17, No. 10, pp. 939-948.

Moors, M. et al. (2009), "Human neurospheres as three-dimensional cellular systems for developmental neurotoxicity testing", Environmental Health Perspectives, Vol. 117, No. 7, pp. 11318 .

Mori, K. et al. (1995), "Thyroid hormone regulates rat placental type III iodothyronine deiodinase activity by inducing kinetic changes different from those in the same isozyme in rat brain", Endocrine Journal, Vol. 42, No. 6, pp. 753-60.

Murk, A. J. et al. (2013), "Mechanism-based testing strategy using in vitro approaches for identification of thyroid hormone disrupting chemicals", Toxicology In Vitro, Vol. 27, No. 4, pp. 1320-1346.

Neumann, S. et al. (2010), "A small molecule inverse agonist for the human thyroid-stimulating hormone receptor", Endocrinology, Vol. 151, No. 7, pp. 3454-9. 
OECD (2006) Detailed Review Paper 57: Thyroid Hormone Disruption Assays. OECD Series on Testing and Assessment. Organisation for Economic Cooperation and Development, Paris.

OECD (2008) Detailed Review Paper 97: The Use of Metabolising systems for In Vitro Testing of Endocrine Disruptors. OECD Series on Testing and Assessment. Organisation for Economic Cooperation and Development, Paris.

OECD (2012) Detailed Review Paper 178: Science on Novel In Vitro and In Vivo Screening and Testing Methods and Endpoints for Evaluating Endocrine Disruptors. OECD Series on Testing and Assessment. Organisation for Economic Cooperation and Development, Paris.

Ohba, K., et al. (2011), "GATA2 mediates thyrotropin-releasing hormone-induced transcriptional activation of the thyrotropin beta gene", PLOS One, Vol. 6, No. 4, pp. e18667.

Oka, T. et al. (2013), "Establishment of transactivation assay systems using fish, amphibian, reptilian and human thyroid hormone receptors", Journal of Applied Toxicology, Vol. 33, No. 9, pp. 991-1000.

Paul, K. B. et al. (2013), "Cross-species analysis of thyroperoxidase inhibition by xenobiotics demosntrates conservation of response from pig to rat", Toxicology, Vol. 312, pp. 97-107.

Picchietti, S. et al. (2009), "Thyroid disruptor 1,1,1-trichloro-2,2-bis(p-chlorophenyl)ethane (DDT) prevents internalization of TSH receptor", Cell and Tissue Research, Vol. 336, No. 1, pp. 31-40. Porazzi, P. et al. (2009), "Thyroid gland development and function in the zebrafish model", Molecular and Cellular Endocrinology, Vol. 312, No. 1-2, pp. 14-23.

Powell, K. A. et al. (2000), "Different transporters for tri-iodothyronine (T(3)) and thyroxine (T(4)) in the human choriocarcinoma cell line, JAR", The Journal of Endocrinology, Vol. 167, No. 3, pp. 48792.

Raldúa, D. and P.J. Babin (2009), "Simple, rapid zebrafish larva bioassay for assessing the potential of chemical pollutants and drugs to disrupt thyroid gland function", Environmental Science \& Technology, Vol. 43, No. 17, pp. 6844-50.

Raldúa, D., B. Thienpont and P.J. Babin (2012), "Zebrafish eleutheroembryos as an alternative system for screening chemicals disrupting the mammalian thyroid gland morphogenesis and function", Reproductive Toxicology, Vol. 33, No. 2, pp. 188-197.

Renko, K. et al. (2012), "Identification of Iopanoic Acid as Substrate of Type 1 Deiodinase by a Novel Nonradioactive Iodide-Release Assay”, Endocrinology, Vol. 153, No. 5, pp. 2506-2513.

Richard, K. et al. (1998), "Ontogeny of iodothyronine deiodinases in human liver", Journal of Clinical Endocrinology \& Metabolism, Vol. 83, No. 8, pp. 2868-74.

Rosebrough, R. W., B. A. Russell and J. P. McMurtry (2006), "Studies on doses of methimazole (MMI) and its administration regimen on broiler metabolism", Comparative Biochemistry and Physiology. Part A, Molecular \& Integrative Physiology, Vol. 143, No. 1, pp. 35-41.

Roti, E. et al. (1982), "Ontogenesis of placental inner ring thyroxine deiodinase and amniotic fluid 3,3',5'-triiodothyronine concentration in the rat", Endocrinology, Vol. 111, No. 3 , pp. 959-63.

Ruf, J. and P. Carayon (2006), "Structural and functional aspects of thyroid peroxidase", Archives of Biochemistry and Biophysics, Vol. 445, No. 2, pp. 269-277. 
Salvatore, D. et al. (1996), "Type 2 iodothyronine deiodinase is highly expressed in human thyroid", Journal of Clinical Investigation, Vol. 98, No. 4, pp. 962-8.

Salvatore, D. et al. (1996), "Molecular biological and biochemical characterization of the human type 2 selenodeiodinase", Endocrinology, Vol. 137, No. 8, pp. 3308-3315.

Santini, F. et al. (1999), "Serum iodothyronines in the human fetus and the newborn: evidence for an important role of placenta in fetal thyroid hormone homeostasis", Journal of Clinical Endocrinology Metabolism, Vol. 84, No. 2, pp. 493-8.

Santini, F. et al. (2003), "In vitro assay of thyroid disruptors affecting TSH-stimulated adenylate cyclase activity", Journal of Endocrinological Investigation, Vol. 26, No. 10, pp. 950-5.

Schmutzler, C. et al. (2007), "The ultraviolet filter benzophenone 2 interferes with the thyroid hormone axis in rats and is a potent in vitro inhibitor of human recombinant thyroid peroxidase", Endocrinology, Vol. 148, No. 6, pp. 2835-44.

Scholz, G. H. et al. (1997), "Inhibition of thyroid hormone uptake by calcium antagonists of the dihydropyridine class", Journal of Medicinal Chemistry, Vol. 40, No. 10, pp. 1530-8.

Schreiber, T. (2010), "Polybrominated diphenyl ethers induce developmental neurotoxicity in a human in vitro model: evidence for endocrine disruption", Environmental Health Perspectives, Vol. 118, No. 4 , pp. $572-8$.

Schriks, M. et al. (2007), "Thyroid hormone receptor isoform selectivity of thyroid hormone disrupting compounds quantified with an in vitro reporter gene assay", Environmental Toxicology and Pharmacology, Vol. 23, No. 3. pp. 302-307.

Schwartz, C. E. et al. (2005), "Allan-Herndon-Dudley syndrome and the monocarboxylate transporter 8 (MCT8) gene”, American Journal of Human Genetics, Vol. 77, No. 1, pp. 41-53.

Sharlin DS, Gilbert ME, Taylor MA, Ferguson DC, Zoeller RT (2010).The nature of the compensatory response to low thyroid hormone in the developing brain. Neuroendocrinol. 22(3):153-65.

Silva, J.E. (1995), "Thyroid hormone control of thermogenesis and energy balance", Thyroid, Vol. 5, No. 6, pp. 481-92.

Shiizaki, K. eta al. (2010), "Establishment of yeast reporter assay systems to detect ligands of thyroid hormone receptors $\alpha$ and $\beta$ ", Toxicology In Vitro, Vol. 24, No. 2, pp. 638-644.

Simeonov, A. et al. (2008), "Fluorescence spectroscopic profiling of compound libraries", Journal of Medicinal Chemistry, Vol. 51, No. 8, pp. 2363-2371.

Song M. et al. (2011), "Identification of Classifiers for Increase or Decrease of Thyroid Peroxidase Activity in the FTC-238/hTPO Recombinant", Environmental Science \& Technology, Vol. 45: 79067914.

St Germain D.L. and V.A. Galton (1997), "The deiodinase family of selenoproteins", Thyroid, Vol. 7, No. 4, pp. 655-68. 
Sugiyama, S., H. Miyoshi and K. Yamauchi (2005), "Characteristics of a thyroid hormone response reporter gene transduced into a Xenopus laevis cell line using lentivirus vector", General and Comparative Endocrinology, Vol. 144, No. 3, pp. 270-279.

Sugiyama, S. (2005), "Detection of thyroid system-disrupting chemicals using in vitro and in vivo screening assay", Toxicological Sciences, Vol. 88, No. 2, pp. 367-374.

Sugawara, M., Y. Sugawara and K. Wen (1999), "Methimazole and propylthiouracil increase cellular thyroid peroxidase activity and thyroid peroxidase mRNA in cultured porcine thyroid follicles", Thyroid, Vol. 9, No. 5, pp. 513-518.

Sun, H. et al. (2012), "Developing in vitro reporter gene assays to assess the hormone receptor activities of chemicals frequently detected in drinking water", Journal of Applied Toxicology, Vol. 32, No. 8, pp. 635-641.

Taurog, A., M. L. Dorris and D. R. Doerge (1996), "Mechanism of simultaneous iodination and coupling catalyzed by thyroid peroxidase", Archives of Biochemistry and Biophysics, Vol. 330, No. 1, pp. 24-32.

Tietge, J. E. et al. (2012), "Inhibition of the thyroid hormone pathway in Xenopus laevis by 2mercaptobenzothiazole", Aquatic Toxicology, Vol. 126, pp. 128-136.

Thienpont, B. et al. (2011), "Zebrafish eleutheroembryos provide a suitable vertebrate model for screening chemicals that impair thyroid hormone synthesis", Environmental Science \& Technology, Vol. 45, No. 17, pp. 7525-32.

Togashi, M. et al. (2005). "Rearrangements in thyroid hormone receptor charge clusters that stabilize bound 3,5',5-triiodo-L-thyronine and inhibit homodimer formation", Journal of Biological Chemistry, Vol. 280, No. 27, pp. 25665-25673.

Topliss, D. J. et al. (1989), "Uptake of 3,5,3'-triiodothyronine by cultured rat hepatoma cells is inhibitable by nonbile acid cholephils, diphenylhydantoin, and nonsteroidal antiinflammatory drugs", Endocrinology, Vol. 124, No. 2, pp. 980-6.

Trepanier, L. A. (2006), "Medical management of hyperthyroidism”, Clinical Techniques in Small Animal Practice, Vol. 21, No. 1, pp. 22-28.

Uribe, R.M. et al. (2009), "17/-Oestradiol Indirectly Inhibits Thyrotrophin-releasing Hormone Expression in the Hypothalamic Paraventricular Nucleus of Female Rats and Blunts Thyroid Axis Response to Cold Exposure", Journal of Neuroendocrinology, Vol. 21, No. 5, pp. 439-48.

Vickers, A. E. et al. (2012), "Thyroid organotypic rat and human cultures used to investigate drug effects on thyroid function, hormone synthesis and release pathways", Toxicology and Applied Pharmacology, Vol. 260, No. 1, pp. 81-88.

Visser, T.J. (1988), "Metabolism of thyroid hormone", in Van der Molen HJ (ed) Hormones and Their Actions, Elsevier, Amsterdam, pp. 81-103.

Visser, W. E., E.C. Friesema and T.J. Visser (2011), "Minireview: thyroid hormone transporters: the knowns and the unknowns", Molecular Endocrinology, Vol. 25, No. 1, pp. 1-14.

Waltz F. et al. (2010), "A Nonradioactive Iodide Uptake Assay for Sodium Iodide Symporter Function", Analytical Biochemistry, Vol. 396, No. 1, 91-95. 
Wang, J. T. and S.W. Xu (2008), "Effects of cold stress on the messenger ribonucleic acid levels of corticotrophin-releasing hormone and thyrotropin-releasing hormone in hypothalami of broilers", Poultry Science, Vol. 87, No. 5, pp. 973-8.

Westholm, D. E. et al. (2009), "Competitive inhibition of organic anion transporting polypeptide 1c1mediated thyroxine transport by the fenamate class of nonsteroidal antiinflammatory drugs", Endocrinology, Vol. 150, No. 2, pp. 1025-32.

Wikberg, J.E. and F. Mutulis (2008), "Targeting melanocortin receptors: an approach to treat weight disorders and sexual dysfunction", Nature Review Drug Discovery, Vol. 7, No. 4, pp. 307-23.

Yan, Z. and P.M. Hinkle (1993), "Saturable, stereospecific transport of 3,5,3'-triiodo-L-thyronine and L-thyroxine into GH4C1 pituitary cells", Journal of Biological Chemistry, Vol. 268, No. 27, pp. 20179-84.

Yen, P.M. (2001), "Physiological and molecular basis of thyroid hormone action", Physiological Reviews. Vol. 81, No. 3, pp. 1097-1142.

Zoeller, R. T. and K. M. Crofton (2005), "Mode of action: developmental thyroid hormone insufficiency--neurological abnormalities resulting from exposure to propylthiouracil", Critical Reviews in Toxicology, Vol. 35, No. 8-9, pp. 771-781.

Zoeller, R.T. and S.W. Tan (2007), "Implications of research on assays to characterize thyroid toxicants", Critical Reviews in Toxicology, Vol. 37, No. 1-2, pp. 195-210. 
O.E.C.D.

\title{
PART TWO:
}

\author{
COMPENDIUM OF \\ IN VITRO \& EX VIVO ASSAYS \\ FOR THYROID HORMONE DISRUPTORS
}




\section{TABLE OF CONTENTS}

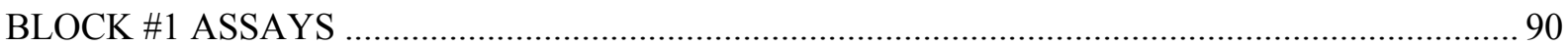

1.1 Hypothalamic Thyrotropin-Releasing Hormone (TRH) Production/Release Assays................. 90

1.2 Thyrotropin Releasing Hormone Receptor Activation Assays ................................................ 92

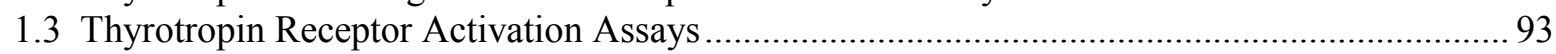

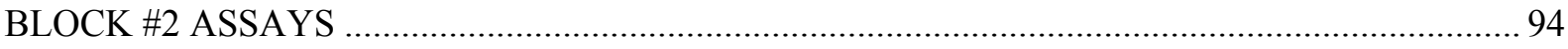

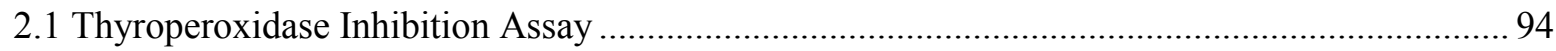

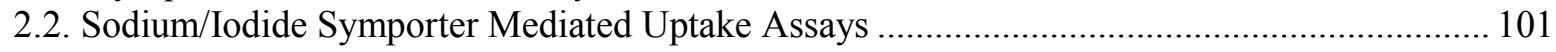

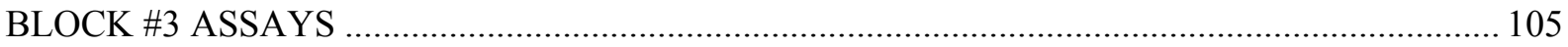

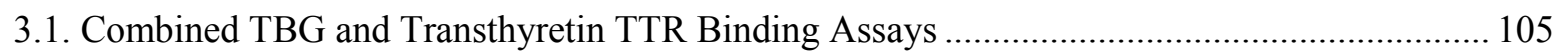

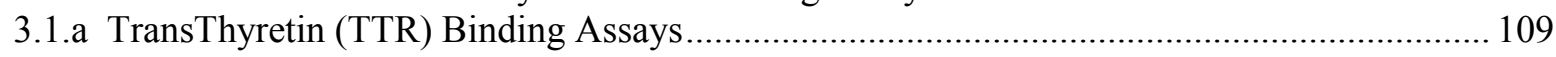

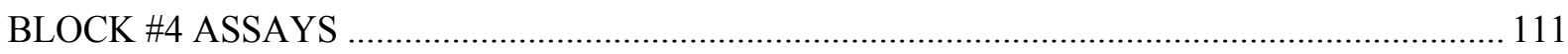

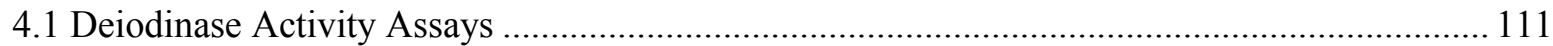

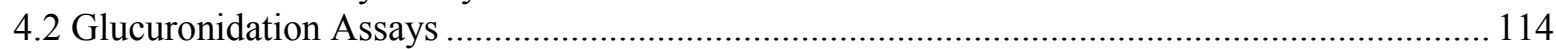

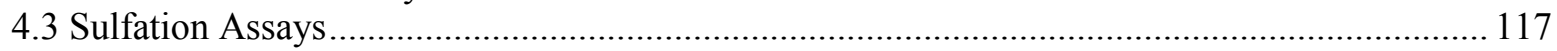

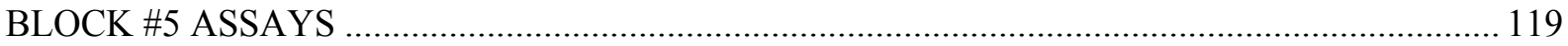

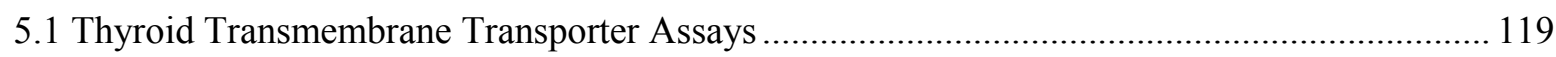

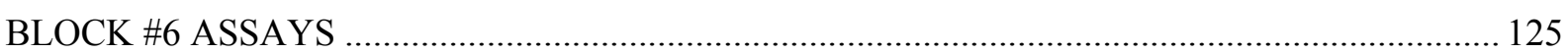

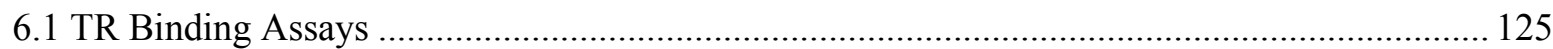

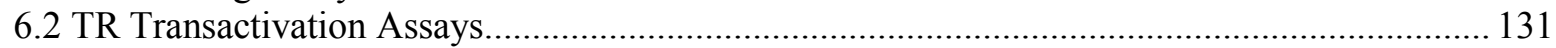

6.3. Assays that Evaluate Interactions of TR With Other Regulatory Proteins ............................... 133

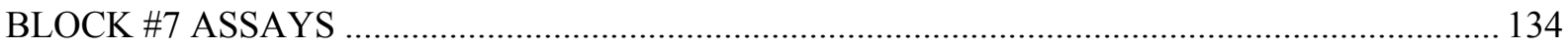

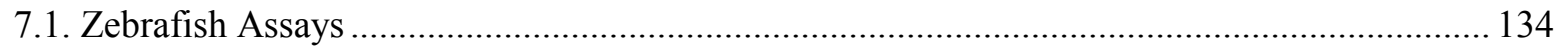

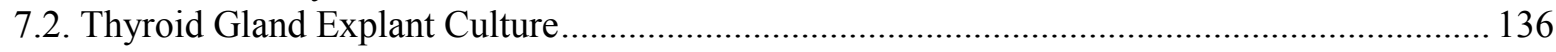

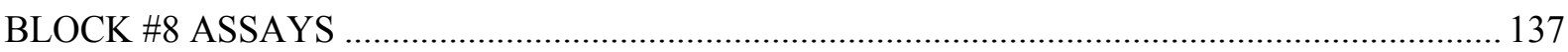

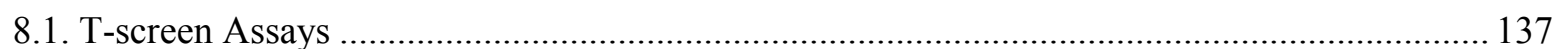

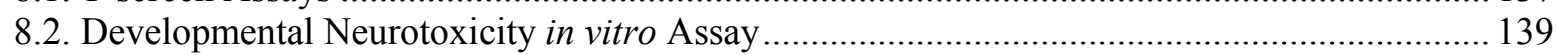

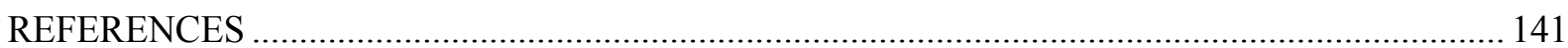

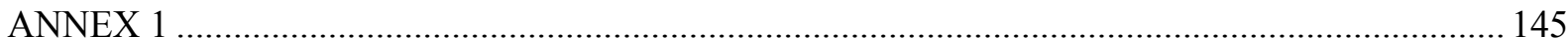


The Part 2 of the Thyroid Scoping document contains a compendium of in vitro \& ex vivo assays for identification of potential thyroid hormone disruptors. The analysis of their readiness for inclusion in the OECD Test Guideline Programme is represented in Part 1. The summary of this analysis is represented in Table 1.3 in Part 1 also included below.

The TSEG assessed the readiness of the assays described in Part 2 for inclusion in the TG work plan based primarily on Category 1 parameters as described above, but including others when available. The table below summarises the findings of the evaluation. 
Table 1. Summary of the in vitro and ex vivo Thyroid Assays and the Level of Their Readiness for Inclusion in the OECD Test Guidelines (TG) Work plan

\begin{tabular}{|c|c|}
\hline Block of Assays & Readiness Level \\
\hline \multicolumn{2}{|l|}{ [1] Central Regulation (HPT) } \\
\hline TRH production (Hypothalamus) & $\mathrm{C}$ \\
\hline TRH receptor activation (Pituitary) & $\mathrm{B}$ \\
\hline TSH receptor activation (Thyroid) & B \\
\hline \multicolumn{2}{|l|}{ [2] Thyroid Hormone Synthesis } \\
\hline TPO Inhibition & $\mathrm{B}$ to $\mathrm{A}$ \\
\hline NIS activation & $\mathrm{B}$ \\
\hline Stem cell derived thyrocytes & not analysed \\
\hline \multicolumn{2}{|l|}{ [3] Secretion and Transport } \\
\hline TTR Binding & A \\
\hline TBG Binding & $\mathrm{A}$ \\
\hline Transport over placenta \& BBB & not analysed \\
\hline \multicolumn{2}{|l|}{ [4] Metabolism and Excretion } \\
\hline Deiodination Inhibition & $\mathrm{B}$ \\
\hline Deiodination up-regulation & $\mathrm{B}$ \\
\hline Hepatic nuclear receptor activation & Covered in Metabolism DRP97 \\
\hline Glucuronidation inhibition & Covered in Metabolism DRP97 \\
\hline Glucuronidation \& Sulfation upregulations & Covered in Metabolism DRP97 \\
\hline Sulfation inhibition & Covered in Metabolism DRP97 \\
\hline \multicolumn{2}{|l|}{ [5] Local Cellular Concentrations } \\
\hline TH Membrane Transporters & $\mathrm{A}$ \\
\hline TH Membrane Transporter/TR Transactivation & B \\
\hline Local Deiodination & $\mathrm{C}$ \\
\hline \multicolumn{2}{|l|}{ [6] Cellular Responses } \\
\hline Binding to TR LBD & $\mathrm{C}$ to $\mathrm{B}$ \\
\hline Effects of TR Transactivation & $\mathrm{B}$ to $\mathrm{A}$ \\
\hline Co Regulator Interaction & Not analysed \\
\hline Activation dimerization partners TR (RXR) & Covered in DRP 178, DRP 97 \\
\hline Non-Nuclear TR mediated responses & Not analysed \\
\hline \multicolumn{2}{|c|}{ [7] Relevant Short-Term Assays Integrating Multiple MOAs } \\
\hline Zebra fish embryo & $\mathrm{B}$ \\
\hline Sea Urchin Metamorphosis assay & not analysed \\
\hline GFP-Xenopus Embryo & TG under development in Project 2.39 \\
\hline Short term Xenopus Metamorphosis assay & not analysed \\
\hline Thyroid gland explant culture & $\mathrm{B}$ \\
\hline \multicolumn{2}{|l|}{ [8] Integrative Cellular Assays } \\
\hline T-Screen (TR induced proliferation assay & $\mathrm{C}$ \\
\hline Human neural progenitor cell & $\mathrm{C}$ \\
\hline TSH induced proliferation assay & not analysed \\
\hline
\end{tabular}




\section{BLOCK \#1 ASSAYS}

\section{CENTRAL REGULATION: HYPOTHALAMIC-PITUITARY-THYROID AXIS (HPT)}

98. This block includes assays with a potential to evaluate synthesis/production of Thyrotropin Releasing Hormone (TRH) at the hypothalamus level, the function/activation of the TRH-Receptor at the pituitary level and of the Thyroid Stimulating Hormone (TSH) Receptor (at the thyroid level).

\subsection{Hypothalamic Thyrotropin-Releasing Hormone (TRH) Production/Release Assays}

\begin{tabular}{|c|c|}
\hline Assay Name & Hypothalamic TRH production and release \\
\hline $\begin{array}{l}\text { Molecular } \\
\text { Initiation Event or } \\
\text { Key Event }\end{array}$ & $\begin{array}{l}\text { Low T3 levels, increased leptin/ MC4R signalling, modulated cAMP levels in the } \\
\text { TRH producing neurons in the paraventricular nucleus of the hypothalamus }\end{array}$ \\
\hline $\begin{array}{l}\text { Endpoint(s)/ } \\
\text { purpose of the } \\
\text { assay }\end{array}$ & $\begin{array}{l}\text { Assess effects on chemicals on } \mathrm{T} 3 \text { repression on } \mathrm{TRH} \text { transcription and } \\
\text { production. }\end{array}$ \\
\hline $\begin{array}{l}\text { Major literature } \\
\text { citations }\end{array}$ & $\begin{array}{l}\text { Lezoualc'h et al., Mol Endocrinol, 1992. 6(11): p. 1797-804; Fekete and Lechan, } \\
\text { Front Neuroendocrinol, 2007. 28(2-3): p. 97-114; Hollenberg et al. J Biol Chem, } \\
\text { 1995. 270(24): 14274-80; Decherf et al., Mol Cell Endocrinol, 2010. 323(2): p. } \\
\text { 172-82. }\end{array}$ \\
\hline $\begin{array}{l}\text { Tissue, Cells or } \\
\text { Extract utilized in } \\
\text { assay and species } \\
\text { source }\end{array}$ & $\begin{array}{l}\text { Mouse or chick embryonic hypothalamic neurons could be used to establish lines } \\
\text { for TRH production. Medium assayed using the commercially available TRH } \\
\text { ELISA from http://www.mybiosource.com/datasheet.php?products_id=741538. }\end{array}$ \\
\hline $\begin{array}{l}\text { Laboratories } \\
\text { performing the } \\
\text { work }\end{array}$ & None \\
\hline $\begin{array}{l}\text { Availability of } \\
\text { assay components } \\
\text { for wide use }\end{array}$ & Not available \\
\hline Assay throughput & Low \\
\hline $\begin{array}{l}\text { Development } \\
\text { stage and } \\
\text { validation status - } \\
\text { further needs }\end{array}$ & $\begin{array}{l}\text { TRH, a tripeptide, is produced from preprothryotropin releasing hormone. } \\
\text { Theoretically, primary cultures of TRH neurons could be prepared and/or } \\
\text { potentially transformed to end used to measure either preprothryotropin mRNA } \\
\text { or protein levels and/or transcriptional regulation. Such assays require } \\
\text { conceptualization, standardization and validation. Cytotoxicity should be } \\
\text { assessed. }\end{array}$ \\
\hline Chemicals tested & $\begin{array}{l}\text { The only chemicals that have been tested on the mouse in vivo assay were TBT } \\
\text { and TBBPA, but other chemicals targeting TRs or RXRs, or deiodinases should } \\
\text { be evaluated. }\end{array}$ \\
\hline $\begin{array}{l}\text { Known } \\
\text { restrictions of the } \\
\text { assay }\end{array}$ & $\begin{array}{l}\text { A chemical assay is available for TRH, but no suitable biological assay that } \\
\text { replays neuron and TR specific physiological regulation of Trh nor TRH } \\
\text { production. }\end{array}$ \\
\hline \multicolumn{2}{|l|}{$\begin{array}{l}\text { Additional } \\
\text { information }\end{array}$} \\
\hline $\begin{array}{l}\text { Are data from } \\
\text { studies publically } \\
\text { available }\end{array}$ & No \\
\hline Assay included in & No, not included in OECD DRP 57 (2006) or DRP 178 ( 2012) \\
\hline
\end{tabular}




\begin{tabular}{|c|c|}
\hline OECD DRPs? & \\
\hline $\begin{array}{l}\text { Proposed/potential } \\
\text { regulatory } \\
\text { purpose }\end{array}$ & $\begin{array}{l}\text { An in vitro assay of Trh transcription and /or TRH production and release does } \\
\text { not currently exists. No synthetic substances have been observed to act via this } \\
\text { MOA. Given the potential for these thyroid hormone dependent regulations to be } \\
\text { affected by endocrine disruption, an assay should be developed. }\end{array}$ \\
\hline
\end{tabular}




\subsection{Thyrotropin Releasing Hormone Receptor Activation Assays}

\begin{tabular}{|c|c|}
\hline Assay Name & TRH-R activation of pituitary thyreotropes \\
\hline $\begin{array}{l}\text { Molecular } \\
\text { Initiation Event or } \\
\text { Key Event }\end{array}$ & $\begin{array}{l}\text { TRH stimulation or TRH-R, activation of phospholipase } \mathrm{C}, \mathrm{Ca}++ \text { mobilization } \\
\text { and activation of PKC, leading to activation of TSHb transcription. }\end{array}$ \\
\hline $\begin{array}{l}\text { Endpoint }(\mathrm{s}) / \\
\text { purpose of the } \\
\text { assay }\end{array}$ & $\begin{array}{l}\text { A number of endpoints of TRH-R activation could be taken as endpoints, be it } \\
\text { Inositol phosphate production, PKC activation or production of TSH b subunit. } \\
\text { In parallel, cell toxicity needs to be assessed for example by using green } \\
\text { fluorescent protein (GFP) (reduction of fluorescence would match with cell } \\
\text { toxicity). The assessment of cell toxicity is mandatory when testing potential } \\
\text { antagonists. }\end{array}$ \\
\hline $\begin{array}{l}\text { Major literature } \\
\text { citations }\end{array}$ & $\begin{array}{l}\text { No literature citations using primary thyrotrophs or GH3 cells for endocrine } \\
\text { disruption of TRH-R action were found }\end{array}$ \\
\hline $\begin{array}{l}\text { Tissue, Cells, } \\
\text { Extract utilized in } \\
\text { assay and species } \\
\text { source }\end{array}$ & $\begin{array}{l}\text { Many species of thyrotrophs could be used. The GH3 lines could be used to } \\
\text { measure GH or prolactin production/secretion in response to TRH stimulation or } \\
\text { the commercial assay cited below. }\end{array}$ \\
\hline $\begin{array}{l}\text { Laboratories } \\
\text { performing the } \\
\text { work }\end{array}$ & $\mathrm{N} / \mathrm{A}$ \\
\hline $\begin{array}{l}\text { Availability of } \\
\text { assay components } \\
\text { for wide use }\end{array}$ & $\begin{array}{l}\text { A commercial assay is available for TRH-R activation - MILLIPORE. } \\
\text { ChemiScreen }{ }^{\mathrm{TM}} \text { Human recombinant TRH Thyrotropin-Releasing Hormone } \\
\text { Receptor, Calcium-Optimized Stable Cell Line. Catalogue Number : HTS126C. } \\
\text { This assay measures Ca++ flux. }\end{array}$ \\
\hline Assay throughput & high, medium, low? \\
\hline $\begin{array}{l}\text { Development } \\
\text { stage and } \\
\text { validation status - } \\
\text { further needs }\end{array}$ & TRH assay needs setting up, optimization and validation. \\
\hline Chemicals tested & Should list total number of chemicals tested using the assay. \\
\hline $\begin{array}{l}\text { Known } \\
\text { restrictions of the } \\
\text { assay }\end{array}$ & $\begin{array}{l}\text { The fact that the TRH receptor is rapidly internalized and down-regulated has to } \\
\text { be taken into account in developing the assay. In parallel, cell toxicity is assessed } \\
\text { using green fluorescent protein (GFP) (reduction of fluorescence would match } \\
\text { with cell toxicity). The assessment of cell toxicity is mandatory when testing } \\
\text { potential antagonists. }\end{array}$ \\
\hline $\begin{array}{l}\text { Additional } \\
\text { information }\end{array}$ & ( \\
\hline $\begin{array}{l}\text { Are data from } \\
\text { studies publically } \\
\text { available }\end{array}$ & No \\
\hline $\begin{array}{l}\text { Assay included in } \\
\text { OECD DRPs? }\end{array}$ & No, not included in OECD DRP 57 (2006) or DRP 178 ( 2012) \\
\hline $\begin{array}{l}\text { Proposed/potential } \\
\text { regulatory } \\
\text { purpose }\end{array}$ & The current state is too theoretical for guideline development. \\
\hline
\end{tabular}




\subsection{Thyrotropin Receptor Activation Assays}

\begin{tabular}{|c|c|}
\hline Assay Name & TSH receptor mediated activation of cAMP production in CHO cells. \\
\hline $\begin{array}{l}\text { Molecular } \\
\text { Initiation Event or } \\
\text { Key Event }\end{array}$ & $\begin{array}{l}\text { TSH activates the G protein linked membrane based TSH receptor initiating } \\
\text { production of cAMP and hence activation of CREB dependent target gene } \\
\text { transcription. At high concentrations TSH also stimulates inositol } \\
\text { monophosphate production. The apparent EC } 50 \text { values for TSH -dependent } \\
\text { cAMP and IP1 production were } 0.75 \text { and }>71 \mathrm{mU} / \mathrm{ml} \text {. }\end{array}$ \\
\hline $\begin{array}{l}\text { Endpoint(s)/ } \\
\text { purpose of the } \\
\text { assay }\end{array}$ & $\begin{array}{l}\text { A number of endpoints could be assayed: TSH-dependent production of cAMP is } \\
\text { the one currently used. Alternatives might be TSH dependent transcription of } \\
\text { target endogenous genes or TSH/ CREB sensitive promoters. }\end{array}$ \\
\hline $\begin{array}{l}\text { Major literature } \\
\text { citations }\end{array}$ & $\begin{array}{l}\text { Hinkle et al. Endocrinology, 1980. 106(3):1000-5; Heldin, Endocrinology, } 1994 . \\
\text { 134(5): 2032-6. }\end{array}$ \\
\hline $\begin{array}{l}\text { Tissue, Cells or } \\
\text { Extract utilized in } \\
\text { assay and species } \\
\text { source }\end{array}$ & Chinese hamster ovary cells (CHO) transfected with the TSH-R. \\
\hline $\begin{array}{l}\text { Laboratories } \\
\text { performing the } \\
\text { work }\end{array}$ & $\begin{array}{l}\text { Currently, no labs running this test regularly. Lechan lab in Boston and Csaba } \\
\text { Fekete in Budapest are known to be setting up the assays again. }\end{array}$ \\
\hline $\begin{array}{l}\text { Availability of } \\
\text { assay components } \\
\text { for wide use }\end{array}$ & $\begin{array}{l}\text { A rapid internet search gave no results for TSH-R expressing CHO cell lines. } \\
\text { Perhaps the two labs that previously described them should be contacted. Also } \\
\text { (see above) two labs (one in the USA and one in Europe) are now setting these } \\
\text { assays up again. }\end{array}$ \\
\hline Assay throughput & Could be high throughput. \\
\hline $\begin{array}{l}\text { Development } \\
\text { stage and } \\
\text { validation status - } \\
\text { further needs }\end{array}$ & Research stage. Need development and validation \\
\hline Chemicals tested & DDT, Arochlor 1254 \\
\hline $\begin{array}{l}\text { Known } \\
\text { restrictions of the } \\
\text { assay }\end{array}$ & $\begin{array}{l}\text { Given the fact that stimulation of the TSH receptor also drives the mitogenic } \\
\text { effects of TSH and thereby is implicated in contributing to thyroid cancer } \\
\text { initiation, the effects of chemical of TSH-R mitogenic effects need to be } \\
\text { addressed independently of cAMP activation. TSH activity is also modified by } \\
\text { glycolysation of TSH and this should be taken into accound when choosing } \\
\text { standards for the TSH. }\end{array}$ \\
\hline \multicolumn{2}{|l|}{$\begin{array}{l}\text { Additional } \\
\text { information }\end{array}$} \\
\hline $\begin{array}{l}\text { Are data from } \\
\text { studies publically } \\
\text { available }\end{array}$ & Only two publications use $\mathrm{CHO}$ lines to asses TSH-R disruption. \\
\hline $\begin{array}{l}\text { Assay included in } \\
\text { OECD DRPs? }\end{array}$ & Both references major citations are in DRP 178, Ref 15 is cited in DRP 57. \\
\hline $\begin{array}{l}\text { Proposed/potential } \\
\text { regulatory } \\
\text { purpose }\end{array}$ & $\begin{array}{l}\text { High potential, but mitogenic effects exerted through the TSH-R need to be taken } \\
\text { into account. }\end{array}$ \\
\hline
\end{tabular}




\section{BLOCK \#2 ASSAYS}

\section{THYROID HORMONE SYNTHESIS}

99. This block includes assays with a potential to evaluate effects on Thyroid Hormone (TH) synthesis via monitoring effects on the activity of Tyroperoxidase, Sodium Iodide Symporter (NIS) and potentially other systems that affect the synthetic process.

\subsection{Thyroperoxidase Inhibition Assay}

\begin{tabular}{|c|c|}
\hline Assay Name & Tyrosine iodination assay \\
\hline $\begin{array}{l}\text { Molecular } \\
\text { Initiation Event or } \\
\text { Key Event }\end{array}$ & $\begin{array}{l}\text { This assay models the TPO-catalyzed iodination of tyrosine to form } \\
\text { monoiodotyrosine (MIT) or to iodinate further to diiodothyronine (DIT) on } \\
\text { thyroglobulin within the follicular lumen of thyrocytes. }\end{array}$ \\
\hline $\begin{array}{l}\text { Endpoint(s)/ } \\
\text { purpose of the } \\
\text { assay }\end{array}$ & $\begin{array}{l}\text { HPLC used to monitor the development of MIT and/or DIT in the presence of } \\
\text { TPO and a potential xenobiotic inhibitor. }\end{array}$ \\
\hline $\begin{array}{l}\text { Major literature } \\
\text { citations }\end{array}$ & $\begin{array}{l}\text { Freyberger and Ahr (2006). Toxicology 217, 169-175; Divi and Doerge (1996). } \\
\text { Chem Res Toxicol 9, 16-23; Divi et al. (1997). Biochem Pharmacol 54, 1087- } \\
\text { 1096; Doerge and Takazawa (1990). Chem Res Toxicol 3, 98-101 }\end{array}$ \\
\hline $\begin{array}{l}\text { Tissue, Cells or } \\
\text { Extract utilized in } \\
\text { assay and species } \\
\text { source }\end{array}$ & $\begin{array}{l}\text { Porcine TPO or bovine lactoperoxidase have been used as partially or highly } \\
\text { purified fractions. }\end{array}$ \\
\hline $\begin{array}{l}\text { Laboratories } \\
\text { performing the } \\
\text { work }\end{array}$ & Doerge et al., Freyberger et al., not commonly performed. \\
\hline $\begin{array}{l}\text { Availability of } \\
\text { assay components } \\
\text { for wide use }\end{array}$ & $\begin{array}{l}\text { The method appears highly transferrable, but obtaining thyroid glands as a source } \\
\text { of TPO may be an obstacle (except hog thyroid from slaughterhouses) to use of } \\
\text { this assay in other laboratories. }\end{array}$ \\
\hline Assay throughput & Low to medium \\
\hline $\begin{array}{l}\text { Development } \\
\text { stage and } \\
\text { validation status - } \\
\text { further needs }\end{array}$ & $\begin{array}{l}\text { Research stage. Would require further standardization and validation. Few } \\
\text { chemicals have been tested using this method. No standardized protocol, assay } \\
\text { not widely used. }\end{array}$ \\
\hline Chemicals tested & $\begin{array}{l}\text { Across different publications 5-10 chemicals have been tested. Positive } \\
\text { chemicals include phytoestrogens (genistein, daidzein, etc.), thiourea derivatives } \\
\text { (ethylenethiourea, N,N, N',N'-tetramethylthiourea), resorcinol. A negative } \\
\text { compound does not appear to have been published. }\end{array}$ \\
\hline $\begin{array}{l}\text { Known } \\
\text { restrictions of the } \\
\text { assay }\end{array}$ & $\begin{array}{l}\text { Relatively low-throughput. Identification of negatives may be problematic. The } \\
\text { UV absorbance of some compounds, including phytoestrogens, may interfere } \\
\text { with spectrophotometric analysis, and thereby necessitate the use of HPLC for } \\
\text { quantitative measurement of products from this assay (Divi et al., 1997). }\end{array}$ \\
\hline $\begin{array}{l}\text { Additional } \\
\text { information }\end{array}$ & $\begin{array}{l}\text { Freyberger et al. (2006) reported final assay conditions in a } 0.5 \mathrm{~mL} \text { volume and a } \\
15 \text { min incubation as: } 500 \mu \mathrm{M} \text { L-tyrosine, } 10 \mathrm{mM} \mathrm{KI}, 250 \mu \mathrm{M} \mathrm{H}_{2} \mathrm{O}_{2}, 0.2 \\
\text { guaiacol units/mL TPO with } 1 \mathrm{mM} \text { sodium thiosulfate, and half a volume of } \\
\text { methanol added to terminate the reaction. Detection of monoiodo-l-tyrosine was } \\
\text { performed by HPLC and UV detection ( } 285 \mathrm{nM} \text { ) to determine peak areas. A } \\
\text { similar detection method was reported by Doerge and colleagues, except that } \\
\text { their method also reported development of DIT in addition to MIT (Divi et al., }\end{array}$ \\
\hline
\end{tabular}




\begin{tabular}{|l|l|}
\hline & $\begin{array}{l}\text { 1997). MIT formation may also be followed up merely photometrically without } \\
\text { HPLC separation step (Diwi and Doerge, 1996), however, frequently compounds } \\
\text { interfere due to their absorptin properties.The tyrosine iodination assay can be } \\
\text { used to detect both interactions with the TPO enzyme and with the iodinating } \\
\text { species generated by TPO. These differences cannot be differentiated in a single } \\
\text { endpoint measurement, but can be discriminated using a time-course experiment } \\
\text { to collect different fractions from column-based HPLC detection. Enzyme } \\
\text { inhibition by a xenobiotic would decrease the slope of the monoiodination } \\
\text { reaction, whereas an interaction with the iodinating intermediate would at least } \\
\text { temporarily suppress iodination at some rate. This assay recapitulates the } \\
\text { physiological key even, as it includes iodination of a tyrosine residue. A positive } \\
\text { result in this assay would be relevant provided that the concentrations use in the } \\
\text { assay were relevant to the toxicokinetics of the compound, and target tissue } \\
\text { concentrations, of the xenobiotic in vivo. }\end{array}$ \\
\hline $\begin{array}{l}\text { Are data from } \\
\text { studies publically } \\
\text { available }\end{array}$ & $\begin{array}{l}\text { Data from these studies are publically available through the published literature. } \\
\text { The authors have not been asked for raw data. }\end{array}$ \\
\hline \multirow{2}{*}{$\begin{array}{l}\text { Assay included in } \\
\text { OECD DRPs? }\end{array}$} & $\begin{array}{l}\text { No, not included in OECD DRP 57 (2006) or DRP 178 (2012). Thyroperoxidase } \\
\text { (TPO) assays using the same principle and guaiacol or tyrosine substrates have } \\
\text { been in use for a long time and have been included in DRP\#57 and/or 178. In } \\
\text { addition an assay combining TPO activity assay with gene expression analysis } \\
\text { using microarray hybridisation has been developed by (Song M. et al, 2011). } \\
\text { Another assay using substrate developed for spectroscopic detection systems has } \\
\text { been developed by Vickers et al.; 2012) }\end{array}$ \\
\hline $\begin{array}{l}\text { Proposed/potential } \\
\text { regulatory } \\
\text { purpose }\end{array}$ & $\begin{array}{l}\text { This assay may be more appropriate as a confirmatory assay following screening. } \\
\text { Substances that inhibit TPO may result in hypothyroxinemia/hypothyroidism, } \\
\text { with potential deleterious effects if exposure occurs during neurodevelopment. }\end{array}$ \\
\hline
\end{tabular}




\begin{tabular}{|c|c|}
\hline Assay Name & Iodide oxidation assay \\
\hline $\begin{array}{l}\text { Molecular } \\
\text { Initiation Event or } \\
\text { Key Event }\end{array}$ & $\begin{array}{l}\text { This assay models the TPO-catalyzed oxidation of iodide. The oxidized iodine } \\
\text { species is key for the iodination of tyrosine to form monoiodotyrosine (MIT) or } \\
\text { to iodinate further to diiodothyronine (DIT) on thyroglobulin within the follicular } \\
\text { lumen of thyrocytes. }\end{array}$ \\
\hline $\begin{array}{l}\text { Endpoint }(\mathrm{s}) / \\
\text { purpose of the } \\
\text { assay }\end{array}$ & $\begin{array}{l}\text { This assay measures the formation of tri-anion } \mathrm{I}_{3}{ }^{-} \text {from } \mathrm{I}_{2} \text { catalyzed by TPO in the } \\
\text { presence of excess iodide. }\end{array}$ \\
\hline $\begin{array}{l}\text { Major literature } \\
\text { citations }\end{array}$ & $\begin{array}{l}\text { Freyberger and Ahr (2006 Toxicology 217, 169-175; Magnusson et al. (1984). J } \\
\text { Biol Chem 259, 13783-13790; Doerge and Takazawa (1990). Chem Res Toxicol } \\
\text { 3, 98-101; } \\
\text { Taurog, A. (1970) Rec Prog Hormone Res 26, 189-247; Schmutzler et al. (2007) } \\
\text { Endocrinology 148, 2835-2844 }\end{array}$ \\
\hline $\begin{array}{l}\text { Tissue, Cells or } \\
\text { Extract utilized in } \\
\text { assay and species } \\
\text { source }\end{array}$ & $\begin{array}{l}\text { Porcine/human recombinant TPO or bovine lactoperoxidase have been used as } \\
\text { partially or highly purified fractions. }\end{array}$ \\
\hline $\begin{array}{l}\text { Laboratories } \\
\text { performing the } \\
\text { work }\end{array}$ & $\begin{array}{l}\text { Not routinely performed. Has been performed in Taurog et al., Doerge et al., } \\
\text { Schmutzler et al., and Freyberger et al. }\end{array}$ \\
\hline $\begin{array}{l}\text { Availability of } \\
\text { assay components } \\
\text { for wide use } \\
\text { (public or } \\
\text { commercial, or } \\
\text { not available) }\end{array}$ & $\begin{array}{l}\text { The method appears highly transferrable, but obtaining thyroid glands as a source } \\
\text { of TPO may be an obstacle (except hog thyroid from slaughterhouses) to use of } \\
\text { this assay in other laboratories. Use of lactoperoxidase may make this more } \\
\text { feasible. There is no standardized assay protocol. Reported assay conditions have } \\
\text { been variable, with a range of iodide ( } 5 \text { to } 50 \mathrm{mM} \text { ) and co-substrate hydrogen } \\
\text { peroxide ( } 100 \text { to } 250 \mu \mathrm{M}) \text { concentrations used by different authors. Occasionally, } \\
\text { lower iodide concentrations were used during the incubation time, and additional } \\
\text { iodide was added only at the end of the incubation time in order to maximize tri- } \\
\text { anion formation. The source of the TPO enzyme and its specific activity has not } \\
\text { typically been standardized or reported. It is unclear, if and how changes in assay } \\
\text { conditions affect the sensitivity of the assay. }\end{array}$ \\
\hline Assay throughput & Low \\
\hline $\begin{array}{l}\text { Development } \\
\text { stage and } \\
\text { validation status - } \\
\text { further needs }\end{array}$ & $\begin{array}{l}\text { Research stage. Would require further standardization and validation. Few } \\
\text { chemicals have been tested using this method. }\end{array}$ \\
\hline Chemicals tested & $\begin{array}{l}\text { Estimate ten chemicals, across different publications including genistein, thiourea } \\
\text { derivatives (ethylenethiourea, N,N, N',N'-tetramethylthiourea), resorcinol, } \\
\text { sulfonamides (sulfathiazole, sulfadiazine), p-aminosalicylic acid, aromatic and } \\
\text { arylamines (4,4'-oxydianiline, 4,4'-methylenedianiline, amitrole), and } \\
\text { benzophenone-2. Negatives have not been published. }\end{array}$ \\
\hline $\begin{array}{l}\text { Known } \\
\text { restrictions of the } \\
\text { assay }\end{array}$ & $\begin{array}{l}\text { Relatively low-throughput. Identification of negatives may be problematic. } \\
\text { Species differences for TPO activity between different sources may contribute } \\
\text { unknown variability. }\end{array}$ \\
\hline $\begin{array}{l}\text { Additional } \\
\text { information }\end{array}$ & $\begin{array}{l}\text { The iodide oxidation assay can be used to detect both interactions with the TPO } \\
\text { enzyme and with the iodinating species generated by TPO. These differences can } \\
\text { be discriminated using a time-course experiment using HPLC detection. This } \\
\text { assay recapitulates the physiological key even, as it measures oxidation of iodide. } \\
\text { A positive result in this assay would be relevant provided that the concentrations } \\
\text { use in the assay were relevant to the toxicokinetics of the compound, and target }\end{array}$ \\
\hline
\end{tabular}




\begin{tabular}{|l|l|}
\hline & tissue concentrations, of the xenobiotic in vivo. \\
\hline $\begin{array}{l}\text { Are data from } \\
\text { studies publically } \\
\text { available }\end{array}$ & Data from these studies are publically available through the published literature. \\
\hline $\begin{array}{l}\text { Assay included in } \\
\text { OECD DRPs? }\end{array}$ & No, not included in OECD DRP 57 (2006) or DRP 178 (2012) \\
\hline $\begin{array}{l}\text { Proposed/potential } \\
\text { regulatory } \\
\text { purpose }\end{array}$ & $\begin{array}{l}\text { Substances that inhibit TPO may disrupt thyroid hormones in vivo to result in } \\
\text { hypothyroxinemia or hypothyroidism, with potential deleterious effects if } \\
\text { exposure occurs during neurodevelopment. }\end{array}$ \\
\hline
\end{tabular}




\begin{tabular}{|c|c|}
\hline Assay Name & Guaiacol oxidation assay \\
\hline $\begin{array}{l}\text { Molecular } \\
\text { Initiation Event or } \\
\text { Key Event }\end{array}$ & $\begin{array}{l}\text { This assay is intended to model TPO catalytic activity that ultimately results in } \\
\text { the coupling of monoiodotyrosine (MIT) and/or diiodothyronine (DIT) on } \\
\text { thyroglobulin within the follicular lumen of thyrocytes }\end{array}$ \\
\hline $\begin{array}{l}\text { Endpoint }(\mathrm{s}) / \\
\text { purpose of the } \\
\text { assay }\end{array}$ & $\begin{array}{l}\text { The guaiacol oxidation assay for peroxidation activity utilizes } \mathrm{H}_{2} \mathrm{O}_{2} \text { as a } \\
\text { hydrogen-donor for TPO-mediated oxidation of guaiacol to an amberdimethoxy- } \\
\text { diphen product detected by spectrophotometric analysis. This assay mimics the } \\
\text { initial step of the coupling reaction catalyzed by TPO, i.e., peroxidation of } \\
\text { substrate, and not iodination. }\end{array}$ \\
\hline $\begin{array}{l}\text { Major literature } \\
\text { citations }\end{array}$ & $\begin{array}{l}\text { Chang and Doerge (2000) ToxicolAppl Pharmacol168, 244-252; Hosoya (1963) } \\
\text { Journal of biochemistry 53, 381-388; Schmutzler et al. (2007), Endocrinology } \\
\text { 148, 2835-2844; Taurog (1970). Rec Prog Hormone Res 26, 189-247; Freyberger } \\
\text { and Ahr (2006). Toxicology 217, 169-175; Takayama et al. (1986) Toxicol Appl } \\
\text { Pharmacol 82:191-199, Takayama et al. }\end{array}$ \\
\hline $\begin{array}{l}\text { Tissue, Cells or } \\
\text { Extract utilized in } \\
\text { assay and species } \\
\text { source }\end{array}$ & $\begin{array}{l}\text { Porcine/rat/monkey/human recombinant and human goiter TPO or bovine } \\
\text { lactoperoxidase have been used as partially or highly purified fractions. }\end{array}$ \\
\hline $\begin{array}{l}\text { Laboratories } \\
\text { performing the } \\
\text { work }\end{array}$ & US EPA, Bayer Health Care, Dan Doerge, Schmutzler \\
\hline $\begin{array}{l}\text { Availability of } \\
\text { assay components } \\
\text { for wide use } \\
\text { (public or } \\
\text { commercial, or } \\
\text { not available) } \\
\end{array}$ & $\begin{array}{l}\text { The method appears highly transferrable, but obtaining thyroid glands as a source of TPO } \\
\text { may be an obstacle (except hog thyroid from slaughterhouses) to use of this assay in other } \\
\text { laboratories. Use of lactoperoxidase (LPO) may make this more feasible. However, LPO } \\
\text { seems to be less sensitive to inhibition than hog thyroid peroxidase. }\end{array}$ \\
\hline Assay throughput & Low. Use as confirmatory assay \\
\hline $\begin{array}{l}\text { Development } \\
\text { stage and } \\
\text { validation status - } \\
\text { further needs }\end{array}$ & $\begin{array}{l}\text { Research stage, but more chemicals have been tested for TPO-inhibiting activity } \\
\text { with this assay than any other. Insufficient numbers of chemicals evaluated for } \\
\text { validation purposes. No standardized protocol exists, different reagent } \\
\text { concentrations across laboratories. Largest differences in execution stem from the } \\
\text { source of protein for the assay. }\end{array}$ \\
\hline Chemicals tested & $\begin{array}{l}\text { Many chemicals have been evaluated with the guaiacol oxidation assay including } \\
\text { phytoestrogens (genistein, daidzein), thiourea derivatives (thiouracil, } \\
\text { propylthiouracil, methimazole), bisphenol A, benzophenone-2, resorcinol, } \\
\text { sulfonamides (sulfathiazole, sulfadiazine, sulfamonomethoxine), p- } \\
\text { aminosalicylic acid, aromatic and arylamines (4,4'-oxydianiline, 4,4,'- } \\
\text { methylenedianiline, amitrole), 2-mercaptobenzothiazole. Negative chemicals } \\
\text { identified include methyl-2-methyl benzoate, 4-methylbenzylidene-camphor, } \\
\text { octylmethoxycinnamate, benzophenone-3, N-acetyl-sulfamonomethoxine, } \\
\text { thiourea derivatives (ethylene thiourea, N,N,N',N'-tetramethylthiourea), } \\
\text { phthalates (diethyl-, dihexyl-, and dibutylphthalate), and iopanoic acid. . }\end{array}$ \\
\hline $\begin{array}{l}\text { Known } \\
\text { restrictions of the } \\
\text { assay }\end{array}$ & $\begin{array}{l}\text { Low-throughput. Not amenable to screening due to the short kinetic window for } \\
\text { the assay and instability of the product formed. There are reported TPO inhibitors } \\
\text { that are less/not inhibitory if guaiacol is used as a substrate. }\end{array}$ \\
\hline \multicolumn{2}{|l|}{$\begin{array}{l}\text { Additional } \\
\text { information }\end{array}$} \\
\hline $\begin{array}{l}\text { Are data from } \\
\text { studies publically }\end{array}$ & Much of these data are publicly available through the open literature. \\
\hline
\end{tabular}




\begin{tabular}{|l|l|}
\hline available & \\
\hline $\begin{array}{l}\text { Assay included in } \\
\text { OECD DRPs? }\end{array}$ & No, not included in OECD DRP 57 (2006) or DRP 178 (2012) \\
\hline $\begin{array}{l}\text { Proposed/potential } \\
\text { regulatory } \\
\text { purpose }\end{array}$ & $\begin{array}{l}\text { Substances that inhibit TPO may disrupt thyroid hormones in vivo to result in } \\
\text { hypothyroxinemia or hypothyroidism, with potential deleterious effects if } \\
\text { exposure occurs during neurodevelopment. }\end{array}$ \\
\hline
\end{tabular}




\begin{tabular}{|c|c|}
\hline Assay Name & Amplex UltraRed ${ }^{\circledR}$ Thyroperoxidase Inhibition Assay \\
\hline $\begin{array}{l}\text { Molecular } \\
\text { Initiation Event or } \\
\text { Key Event }\end{array}$ & $\begin{array}{l}\text { TPO catalytic activity that results in the coupling of monoiodotyrosine (MIT) } \\
\text { and/or diiodothyronine (DIT) on thyroglobulin within the follicular lumen of } \\
\text { thyrocytes. }\end{array}$ \\
\hline $\begin{array}{l}\text { Endpoint }(\mathrm{s}) / \\
\text { purpose of the } \\
\text { assay }\end{array}$ & $\begin{array}{l}\text { The assay utilizes } \mathrm{H}_{2} \mathrm{O}_{2} \text { as a hydrogen-donor for TPO-mediated oxidation of the } \\
\text { Amplex UltraRed substrate to a resorufin-based product (Amplex UltroxRed). } \\
\text { This assay mimics the initial step of the coupling reaction catalyzed by TPO, i.e., } \\
\text { peroxidation of substrate, and not iodination. }\end{array}$ \\
\hline $\begin{array}{l}\text { Major literature } \\
\text { citations }\end{array}$ & $\begin{array}{l}\text { Paul et al. (2013). (in preparation); } \\
\text { http://tools.invitrogen.com/content/sfs/manuals/mp36006.pdf }\end{array}$ \\
\hline $\begin{array}{l}\text { Tissue, Cells, } \\
\text { Extract utilized in } \\
\text { assay and species } \\
\text { source }\end{array}$ & $\begin{array}{l}\text { Rat TPO; porcine TPO possible, but not yet tested; human recombinant TPO } \\
\text { from a new cell line is in development. }\end{array}$ \\
\hline $\begin{array}{l}\text { Laboratories } \\
\text { performing the work }\end{array}$ & US EPA \\
\hline $\begin{array}{l}\text { Availability of } \\
\text { assay components } \\
\text { for wide use } \\
\text { (public or } \\
\text { commercial, or } \\
\text { not available) }\end{array}$ & $\begin{array}{l}\text { The method appears highly transferrable, but obtaining thyroid glands as a source } \\
\text { of TPO may be an obstacle to use of this assay in other laboratories. Use of } \\
\text { human recombinant TPO may enable greater transferability of this assay. }\end{array}$ \\
\hline Assay throughput & High \\
\hline $\begin{array}{l}\text { Development } \\
\text { stage and } \\
\text { validation status - } \\
\text { further needs }\end{array}$ & $\begin{array}{l}\text { This assay has been characterized in a } 96-\text { and a } 384 \text {-well format, with a } \\
\text { publication on a validation with a } 21 \text {-chemical training set to be submitted soon. }\end{array}$ \\
\hline Chemicals tested & $\begin{array}{l}21 \text { chemicals have been evaluated including MMI }>\text { ethylene thiourea }>6 \text { - } \\
\text { propylthiouracil }>2,2^{\prime}, 4,4 \text { '-tetrahydroxy-benzophenone }>2 \text { - } \\
\text { mercaptobenzothiazole }>3 \text {-amino-1,2,4-triazole }>\text { genistein }>4 \text {-propoxyphenol } \\
>\text { sulfamethazine }>\text { daidzein }>4 \text {-nonylphenol }>\text { triclosan }>\text { iopanoic acid }> \\
\text { resorcinol. These data demonstrate the broader utility of this assay to detect } \\
\text { chemicals previously characterized as reversible or irreversible inhibitors of } \\
\text { TPO. Seven chemicals were negative including: } 2 \text {-hydroxy-4- } \\
\text { methoxybenzophenone, dibutylphthalate, diethylhexylphthalate, diethylphthalate, } \\
\text { 3,5-dimethylpyrazole-1-methanol, methyl 2-methyl-benzoate, and sodium } \\
\text { perchlorate. }\end{array}$ \\
\hline $\begin{array}{l}\text { Known } \\
\text { restrictions of the } \\
\text { assay }\end{array}$ & $\begin{array}{l}\text { Assay does not recapitulate a physiological key event, but rather serves as an } \\
\text { indicator of TPO activity using a nonphysiological substrate. It is unknown if } \\
\text { there are types of TPO inhibitors that may not be detected by this assay. }\end{array}$ \\
\hline $\begin{array}{l}\text { Additional } \\
\text { information }\end{array}$ & $\begin{array}{l}\text { This assay has been evaluated in an automated format in the developing } \\
\text { laboratory. }\end{array}$ \\
\hline $\begin{array}{l}\text { Are data from } \\
\text { studies publically } \\
\text { available }\end{array}$ & $\begin{array}{l}\text { A publication on this assay and the } 21 \text {-chemical training set, using rat thyroid } \\
\text { microsomes as the source of TPO, is in preparation (Paul et al. 2013). }\end{array}$ \\
\hline $\begin{array}{l}\text { Assay included in } \\
\text { OECD DRPs? }\end{array}$ & No, not included in OECD DRP 57 (2006) or DRP 178 ( 2012) \\
\hline $\begin{array}{l}\text { Proposed/potential } \\
\text { regulatory } \\
\text { purpose }\end{array}$ & $\begin{array}{l}\text { Substances that inhibit TPO may disrupt thyroid hormones in vivo to result in } \\
\text { hypothyroxinemia or hypothyroidism, with potential deleterious effects if } \\
\text { exposure occurs during neurodevelopment. }\end{array}$ \\
\hline
\end{tabular}




\subsection{Sodium/Iodide Symporter Mediated Uptake Assays}

\begin{tabular}{|c|c|}
\hline Assay Name & $\begin{array}{l}\text { Radioactive Sodium/Iodide Uptake assay using transiently transfected } \\
\text { FRTL-5 cells }\end{array}$ \\
\hline $\begin{array}{l}\text { Molecular } \\
\text { Initiation Event or } \\
\text { Key Event }\end{array}$ & $\begin{array}{l}\text { Iodide uptake into thyroid follicular cells is carried out by the Sodium Iodide } \\
\text { Symporter (NIS). This is a key event in thyroid hormone synthesis and sensitive } \\
\text { to a number of environmentally relevant compouns including notably } \\
\text { perchlorate, nitrate and genistein. }\end{array}$ \\
\hline $\begin{array}{l}\text { Endpoint }(\mathrm{s}) / \\
\text { purpose of the } \\
\text { assay }\end{array}$ & $\begin{array}{l}\text { The radioactivity of the radioiodide is counted in the presence of inhibitors or } \\
\text { stimulators.. } \\
\text { Radioactivity after Xanthohumol use (through the time) is compared to the } \\
\text { radioactivity of negative control }\left(\mathrm{NaClO}_{4}\right) \text { and statistical analysis is performed } \\
\text { (non-parametric one-way ANOVA) }\end{array}$ \\
\hline $\begin{array}{l}\text { Major literature } \\
\text { citations }\end{array}$ & $\begin{array}{l}\text { Radovic B., Schmutzler C., Kôhrle J., Xanthohumol stimulates iodide uptake in } \\
\text { rat thyroid-derived FRTL-5 cells, in Molecular Nutrition \& Food Research 45, } \\
\text { 2005, pp. 832-836. }\end{array}$ \\
\hline $\begin{array}{l}\text { Tissue, Cells or } \\
\text { Extract utilized in } \\
\text { assay and species } \\
\text { source }\end{array}$ & Rat non transformed thyrocytes (FRTL-5 cells) \\
\hline $\begin{array}{l}\text { Laboratories } \\
\text { performing the } \\
\text { work }\end{array}$ & $\begin{array}{l}\text { Institut für Experimentelle Endokrinologie und Endokrinologisches, } \\
\text { Forschungszentrum EnForCé, Charité Universitätsmedizin Berlin, Berlin, } \\
\text { Germany }\end{array}$ \\
\hline $\begin{array}{l}\text { Availability of } \\
\text { assay components } \\
\text { for wide use }\end{array}$ & 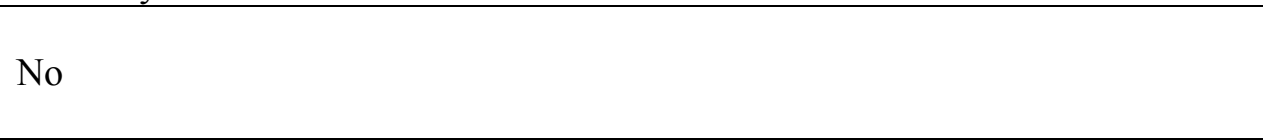 \\
\hline Assay throughput & Low to medium \\
\hline $\begin{array}{l}\text { Development } \\
\text { stage and } \\
\text { validation status - } \\
\text { further needs }\end{array}$ & Research stage \\
\hline Chemicals tested & $\begin{array}{l}\text { Restrictions of the assay as described is that no chemicals known as thyroid } \\
\text { disruptors were tested, because it firstly had goals in cancer research not in } \\
\text { endocrine disruptors research (see known restrictions of the assay). It also lacks } \\
\text { method details. The observation was that NIS was stimulated over } 72 \mathrm{~h} \text { in a non- } \\
\text { dose dependent manner by a plant derived substance, Xanthohumol }\end{array}$ \\
\hline $\begin{array}{l}\text { Known } \\
\text { restrictions of the } \\
\text { assay }\end{array}$ & $\begin{array}{l}\text { This assay only assessed Xanthohumol impact which is not a pollutant/chemical } \\
\text { At first this study aimed to increase radioiodide uptake and assess the use of such } \\
\text { a mechanism in cancer therapy }\end{array}$ \\
\hline $\begin{array}{l}\text { Additional } \\
\text { information }\end{array}$ & $\begin{array}{l}\text { No, the material and methods section is poor. This article does not provide } \\
\text { transparent data. }\end{array}$ \\
\hline $\begin{array}{l}\text { Are data from } \\
\text { studies publically } \\
\text { available }\end{array}$ & Yes, published literature. \\
\hline $\begin{array}{l}\text { Assay included in } \\
\text { OECD DRPs? }\end{array}$ & $\begin{array}{l}\text { No, assay not included in OECD DRP } 57 \text { (2006) or DRP } 178 \text { (2012), but } \\
\text { Schmutzler et al (2007) is a review paper that is cited in DRP } 57 \text { and DRP \#178. }\end{array}$ \\
\hline $\begin{array}{l}\text { Proposed/potential } \\
\text { regulatory } \\
\text { purpose }\end{array}$ & $\begin{array}{l}\text { Potentially, could be used to assess mechanisms of disruption that involve NIS } \\
\text { symporter, BUT should be specifically designed and improved for endocrine } \\
\text { disruptors, please see restrictions of the assay and chemicals tested above in the } \\
\text { table. }\end{array}$ \\
\hline
\end{tabular}




\begin{tabular}{|c|c|}
\hline Assay Name & $\begin{array}{l}\text { Radioactive Sodium/Iodide Uptake Assay using hNIS stably transfected in } \\
\text { FRTL5 cells and in HEK293 cells }\end{array}$ \\
\hline $\begin{array}{l}\text { Molecular } \\
\text { Initiation Event or } \\
\text { Key Event }\end{array}$ & $\begin{array}{l}\text { Iodide uptake into thyroid follicular cells is carried out by the Sodium Iodide } \\
\text { Symporter (NIS). This is a key event in thyroid hormone synthesis and sensitive } \\
\text { to a number of environmentally relevant compouns including notably } \\
\text { perchlorate, nitrate and genistein }\end{array}$ \\
\hline $\begin{array}{l}\text { Endpoint(s)/ } \\
\text { purpose of the } \\
\text { assay }\end{array}$ & $\begin{array}{l}\text { The radioactivity of the radio-iodide }{ }^{125} \text { I is counted. Functional characterization } \\
\text { of iodide uptake activity catalysed by hNIS-HEK } 293 \text { : absence/presence ClO } 4 \\
\text { and } 17020 \text { compounds are screened in the first run. IC } 50 \text { determination of the } \\
\text { selected compounds. }\end{array}$ \\
\hline $\begin{array}{l}\text { Major literature } \\
\text { citations }\end{array}$ & Lecat-Guillet et al., ChemBioChem 9 (2008) 889-895 \\
\hline $\begin{array}{l}\text { Tissue, Cells or } \\
\text { Extract utilized in } \\
\text { assay and species } \\
\text { source }\end{array}$ & Human NIS stably transfected in FRTL5 cells and HEK293 \\
\hline $\begin{array}{l}\text { Laboratories } \\
\text { performing the } \\
\text { work }\end{array}$ & $\begin{array}{l}\text { Department of Bioorganic Chemistry and Isotopic Labelling, CEA, Institue of } \\
\text { Biology and Technology (iBiTecs), Gif-sur-Yvette F-91191, France }\end{array}$ \\
\hline $\begin{array}{l}\text { Availability of } \\
\text { assay components } \\
\text { for wide use }\end{array}$ & All materials used in this assay are commercially available \\
\hline Assay throughput & High \\
\hline $\begin{array}{l}\text { Development } \\
\text { stage and } \\
\text { validation status - } \\
\text { further needs }\end{array}$ & $\begin{array}{l}\text { There is a need to decide which stably transfectd cell type should be taken } \\
\text { forward for validation; either FRTL } 5 \text { cells and HEK } 293 \text { and then whether to test } \\
\text { with the radio-isotope method or the colorimetric method }\end{array}$ \\
\hline Chemicals tested & $\begin{array}{l}\text { The Sodium Iodide Symporter (NIS) is inhibited by certain anions and other } \\
\text { compounds, such as genistein. Lecat-Gullet et al (2008) describe results HTP } \\
\text { screening results using radioactivity iodide uptake assay (RAIU). Each screening } \\
\text { narrows the number of remaining compounds. } 10 \text { compounds were clearly } \\
\text { identified as NIS inhibitors and were thus called 'Iodide Transport Blockers'. }\end{array}$ \\
\hline $\begin{array}{l}\text { Known } \\
\text { restrictions of the } \\
\text { assay }\end{array}$ & $\begin{array}{l}\text { If the radio-isotope method is chose then a restriction would be use of isotopes. } \\
\text { The colorimetric method might be less sensitive and this could be a drawback. }\end{array}$ \\
\hline $\begin{array}{l}\text { Additional } \\
\text { information }\end{array}$ & $\begin{array}{l}\text { Possible bias introduced by compounds that may quench the radioactive signal; } \\
\text { isotopic dilution due to free iodide in the samples; alteration in the membrane } \\
\text { status; cell toxicity of the compounds. }\end{array}$ \\
\hline $\begin{array}{l}\text { Are data from } \\
\text { studies publically } \\
\text { available }\end{array}$ & Yes in the scientific literature \\
\hline $\begin{array}{l}\text { Assay included in } \\
\text { OECD DRPs? }\end{array}$ & No, not included in OECD DRP 57 (2006) or DRP 178 (2012) \\
\hline $\begin{array}{l}\text { Proposed/potential } \\
\text { regulatory } \\
\text { purpose }\end{array}$ & In vitro highthroughput screening assessment of potential disrupting chemicals \\
\hline
\end{tabular}




\begin{tabular}{|c|c|}
\hline Assay Name & $\begin{array}{l}\text { Non-Radioactive Sodium/Iodide Uptake Assay based on Sandell-Kolthoff } \\
\text { reaction and using FRTL5 cells }\end{array}$ \\
\hline $\begin{array}{l}\text { Molecular } \\
\text { Initiation Event or } \\
\text { Key Event }\end{array}$ & $\begin{array}{l}\text { (NIS). This is a key event in thyroid hormone synthesis and sensitive to a } \\
\text { number of environmentally relevant compouns including notably perchlorate, } \\
\text { nitrate and genistein }\end{array}$ \\
\hline $\begin{array}{l}\text { Endpoint(s)/ } \\
\text { purpose of the } \\
\text { assay }\end{array}$ & $\begin{array}{l}\text { The assay is based on the Sandell and Kolthoff reaction between Ce(IV) and } \\
\text { As(III). Ce(IV) yellow becomes uncolored Ce(III); Iodide accelerates this } \\
\text { reaction, with the rate directly proportional to the concentration of iodide. The } \\
\text { maximum absorbance for Ce(IV) is measured at } 420 \mathrm{~nm} \text {; the endpoint is the } \\
\text { decrease of absorbance at } 420 \mathrm{~nm} \text { which is time-dependent and proportional to } \\
\text { the concentration of iodide. }\end{array}$ \\
\hline $\begin{array}{l}\text { Major literature } \\
\text { citations }\end{array}$ & $\begin{array}{l}\text { Waltz F. et al., A Nonradioactive Iodide Uptake Assay for Sodium Iodide } \\
\text { Symporter Function, in Analytical Biochemistry 396(2010), 91-95 }\end{array}$ \\
\hline $\begin{array}{l}\text { Tissue, Cells or } \\
\text { Extract utilized in } \\
\text { assay and species } \\
\text { source }\end{array}$ & Rat thyroid-derived cells (FRTL5) \\
\hline $\begin{array}{l}\text { Laboratories } \\
\text { performing the } \\
\text { work }\end{array}$ & $\begin{array}{l}\text { Commissariat à l'Energie Atomique (CEA), Institut de Biologie de Saclay } \\
\text { (iBiTecs), Service de Chimie Bioorganique et de Marquage, Gif-sur-Yvette F- } \\
\text { 91191, France }\end{array}$ \\
\hline $\begin{array}{l}\text { Availability of } \\
\text { assay components } \\
\text { for wide use } \\
\text { (public or } \\
\text { commercial, or } \\
\text { not available) }\end{array}$ & All materials used in this assay are commercially available \\
\hline Assay throughput & High \\
\hline $\begin{array}{l}\text { Development } \\
\text { stage and } \\
\text { validation status - } \\
\text { further needs }\end{array}$ & Research stage \\
\hline Chemicals tested & $\begin{array}{l}\text { Chemicals to test during validation would be perchlorate, nitrate, genistein and } \\
\text { bromine. ITB5 identified to be the most potent inhibitor (Lecat-Guillet et al., } \\
\text { 2008). }\end{array}$ \\
\hline $\begin{array}{l}\text { Known } \\
\text { restrictions of the } \\
\text { assay }\end{array}$ & $\begin{array}{l}\text { Compounds that can directly reduce Cer-IV to Cer-III could interfere with the } \\
\text { final readout. Also due to the high toxicity of As (III) used in this assay, there } \\
\text { may be legal implications with performing the assay. The following drawbacks } \\
\text { are applicable to any cell based NIS assay: Compounds that may quench the } \\
\text { radioactive signal, Isotopic dilution due to free iodide in the samples, Alteration } \\
\text { in the membrane status, Cell toxicity of the compounds. }\end{array}$ \\
\hline $\begin{array}{l}\text { Additional } \\
\text { information }\end{array}$ & $\begin{array}{l}\text { Reaction to reduce } \mathrm{As} / \mathrm{Ce} \text { is time and iodide concentration dependent. Quantity } \\
\text { of iodide in picomoles range is assessed in FRTL5 cells in 96-well plate format } \\
\text { in presence or absence of sodium perchlorate }\left(\mathrm{NaClO}_{4}\right) \text { a chemical known to be a } \\
\text { strong NIS inhibitor. The decrease of the cell-trapped iodide shows the inhibition } \\
\text { of the NIS by } \mathrm{NaClO}_{4} \text {. } \\
\text { Reliability of the As/Ce method is validated using a set of known iodide uptake } \\
\text { inhibitors and calculation of the IC50 for each and compared with results } \\
\text { radioactive iodide uptake assay (RAIU). }\end{array}$ \\
\hline $\begin{array}{l}\text { Are data from } \\
\text { studies publically }\end{array}$ & Only those in the paper cited. \\
\hline
\end{tabular}




\begin{tabular}{|l|l|}
\hline available & \\
\hline $\begin{array}{l}\text { Assay included in } \\
\text { OECD DRPs? }\end{array}$ & No, not included in OECD DRP 57 (2006) or DRP 178 (2012) \\
\hline $\begin{array}{l}\text { Proposed/potential } \\
\text { regulatory } \\
\text { purpose }\end{array}$ & $\begin{array}{l}\text { In vitro highthroughput screening assessment of potential disrupting chemicals or } \\
\text { pharmaceuticals }\end{array}$ \\
\hline
\end{tabular}




\section{BLOCK \#3 ASSAYS}

\section{SECRETION AND TRANSPORT}

100. This block contains assays with a potential to evaluate disruption of thyroid hormone function by affecting the secretion of the hormone and its systemic transport. In the current document mainly assays evaluating interference of xenobiotics with binding of T3 and/or T4 to thyroxinebinding globuline (TBG) and transthyrein (TTR) are included.

\subsection{Combined TBG and Transthyretin TTR Binding Assays}

\begin{tabular}{|c|c|}
\hline Assay Name & $\begin{array}{l}\text { TBG/TTR non-radioactivity-based assay - Immunomagnetic microbeads, } \\
\text { flow cytometry and nano-liquid chromatography mass spectrometry. }\end{array}$ \\
\hline $\begin{array}{l}\text { Molecular } \\
\text { Initiation Event or } \\
\text { Key Event }\end{array}$ & $\begin{array}{l}\text { Displacement T4 from its binding site on the serum binding proteins TTR or } \\
\text { TBG. }\end{array}$ \\
\hline $\begin{array}{l}\text { Endpoint(s)/ } \\
\text { purpose of the } \\
\text { assay }\end{array}$ & $\begin{array}{l}\text { This assay uses competitive inhibition of a stable nonradioactive isotope of T4 } \\
\text { [(13)C(6)-L-thyroxine] as the label to the binding of a recombinant TTR (rTTR). } \\
\text { rTTR is either used in solution or immobilized on paramagnetic microbeads. The } \\
\text { readout measure of inhibition of rTTR binding is liquid chromatography-mass } \\
\text { spectrometry (LC-MS). The decrease in LC-MS peak is the measure of the } \\
\text { potency of the compound to displace T4. }\end{array}$ \\
\hline $\begin{array}{l}\text { Major literature } \\
\text { citations }\end{array}$ & $\begin{array}{l}\text { Aqai P, et al., Triple bioaffinity mass spectrometry concept for thyroid transporter } \\
\text { ligands. Anal Chem. } 2012 \text { Aug 7;84(15):6488-93. }\end{array}$ \\
\hline $\begin{array}{l}\text { Tissue, Cells or } \\
\text { Extract utilized in } \\
\text { assay and species } \\
\text { source }\end{array}$ & 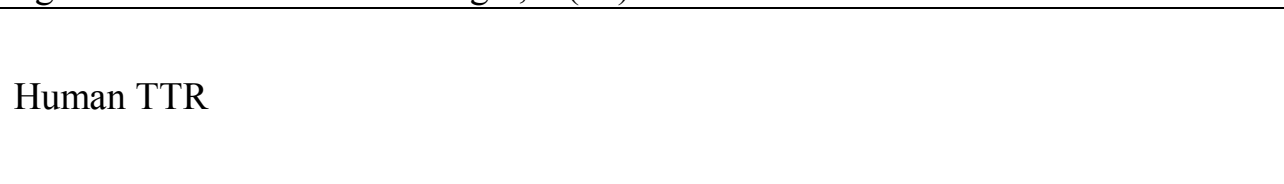 \\
\hline $\begin{array}{l}\text { Laboratories } \\
\text { performing the } \\
\text { work }\end{array}$ & C RIKILT-Institute of Food Safety, Wageningen UR, Akkermaalsbos 2, 6708 WB \\
\hline $\begin{array}{l}\text { Availability of } \\
\text { assay components } \\
\text { for wide use }\end{array}$ & Materials are commercially available. \\
\hline Assay throughput & High \\
\hline \multicolumn{2}{|l|}{$\begin{array}{l}\text { Development } \\
\text { stage and } \\
\text { validation status - } \\
\text { further needs }\end{array}$} \\
\hline Chemicals tested & T4, triclosan, tetrabromobisphenol \\
\hline $\begin{array}{l}\text { Known } \\
\text { restrictions of the } \\
\text { assay }\end{array}$ & Expensive technology \\
\hline \multicolumn{2}{|l|}{$\begin{array}{l}\text { Additional } \\
\text { information }\end{array}$} \\
\hline $\begin{array}{l}\text { Are data from } \\
\text { studies publically } \\
\text { available }\end{array}$ & Yes in published literature \\
\hline Assay included in & No, not included in OECD DRP 57 ( 2006) or DRP 178 ( 2012) \\
\hline
\end{tabular}


ENV/JM/MONO(2014)23

OECD DRPs?

Proposed/potential

regulatory

This in vitro assay may be used for TTR and TBG T4 displacements induced by purpose xenobiotics. Such action by chemicals is hypothesized to increase T4 clearance. 


\begin{tabular}{|l|l|}
\hline Assay Name & TTR/TBG Anilinosulfonic Acid (ANSA) Fluorescence Displacement Assay \\
\hline $\begin{array}{l}\text { Molecular } \\
\text { Initiation Event or } \\
\text { Key Event }\end{array}$ & $\begin{array}{l}\text { Displacement T4 from its binding site on the serum binding proteins TTR or } \\
\text { TBG. }\end{array}$ \\
\hline $\begin{array}{l}\text { Endpoint(s)/ } \\
\text { purpose of the } \\
\text { assay }\end{array}$ & $\begin{array}{l}\text { T4 and T3 bind to TTR and TBG serum proteins.This assay measures the relative } \\
\text { fluorescence intensity provided by ANSA (8-anilino naphthalene sulfonic acid ammonium } \\
\text { salt) which is able to bind serum transport-proteins. Competitive inhibition of } \\
\text { chemicals with binding of T4 or T3 is the endpoint measured in this assay. }\end{array}$ \\
\hline $\begin{array}{l}\text { Major literature } \\
\text { citations }\end{array}$ & Cao J et al, Toxicology 277, 2010, 20-28. \\
\hline $\begin{array}{l}\text { Tissue, Cells or } \\
\text { Extract utilized in } \\
\text { assay and species } \\
\text { source }\end{array}$ & $\begin{array}{l}\text { The article states only on "stock solutions of TTR, TBG [...]", we can assume } \\
\text { that this underlies plasma TTR/TBG (this should be confirmed) }\end{array}$ \\
\hline $\begin{array}{l}\text { Laboratories } \\
\text { performing the } \\
\text { work }\end{array}$ & $\begin{array}{l}\text { State Key Laboratory of Environment Chemistry and Ecotoxicology, Research } \\
\text { Center for Eco-environmental Sciences, Chinese Academy of Sciences, P.O. Box } \\
\text { 2871, Beijing 100085, China }\end{array}$ \\
\hline $\begin{array}{l}\text { Availability of } \\
\text { for wide use }\end{array}$ & Assay throughput \\
\hline $\begin{array}{l}\text { Development } \\
\text { stage and } \\
\text { validation status } \\
\text { further needs }\end{array}$ & Low \\
\hline Chemicals tested & OH-PBDEs \\
\hline $\begin{array}{l}\text { Known } \\
\text { restrictions of the } \\
\text { assay }\end{array}$ & $\begin{array}{l}\text { Should be performed with other known thyroid disruptors. Native fluorescence of } \\
\text { test compounds could interfere with measurements. }\end{array}$ \\
\hline $\begin{array}{l}\text { Additional } \\
\text { information }\end{array}$ & $\begin{array}{l}\text { This assay was performed with OH-PBDEs and these produce disruption by } \\
\text { competitive displacement. This assay could be expanded to other chemicals }\end{array}$ \\
\hline $\begin{array}{l}\text { Are data from } \\
\text { studies publically } \\
\text { available }\end{array}$ & Yes, published literature \\
\hline $\begin{array}{l}\text { Assay included in } \\
\text { OECD DRPs? }\end{array}$ & No, not included in OECD DRP 57 (2006) but was included in DRP 178 (2012). \\
\hline $\begin{array}{l}\text { Proposed/potential } \\
\text { regulatory } \\
\text { purpose }\end{array}$ & $\begin{array}{l}\text { This in vitro assay may be used for TTR and TBG T4 displacements induced by } \\
\text { xenobiotics. Such action by chemicals is hypothesized to increase T4 clearance. }\end{array}$ \\
\hline
\end{tabular}




\begin{tabular}{|c|c|}
\hline Assay Name & TTR/TBG Assays - T4-Coated Biosensor Chip Method \\
\hline $\begin{array}{l}\text { Molecular } \\
\text { Initiation Event or } \\
\text { Key Event }\end{array}$ & $\begin{array}{l}\text { Displacement T4 from its binding site on the serum binding proteins TTR or } \\
\text { TBG. }\end{array}$ \\
\hline $\begin{array}{l}\text { Endpoint }(\mathrm{s}) / \\
\text { purpose of the } \\
\text { assay }\end{array}$ & $\begin{array}{l}\text { This assay is similar to an inhibition immunoassay. It uses a Biacore Q } \\
\text { automatically functioning, providing a Response Units (RU) depending on the } \\
\text { absence or occurrence of inhibited binding. }\end{array}$ \\
\hline $\begin{array}{l}\text { Major literature } \\
\text { citations }\end{array}$ & Marchesini et al, Toxicology and Applied Pharmacology 232, 2008, 150-160 \\
\hline $\begin{array}{l}\text { Tissue, Cells or } \\
\text { Extract utilized in } \\
\text { assay and species } \\
\text { source }\end{array}$ & Recombinant TTR (rTTR) and TBG purchased \\
\hline $\begin{array}{l}\text { Laboratories } \\
\text { performing the } \\
\text { work }\end{array}$ & $\begin{array}{l}\text { RIKILT-Institute of Food Safety, Wageningen UR, P.O. Box 230, } 6700 \text { AE } \\
\text { Wageningen, The Netherlands; gerardo.marchesini@wur.nl }\end{array}$ \\
\hline $\begin{array}{l}\text { Availability of } \\
\text { assay components } \\
\text { for wide use }\end{array}$ & yes \\
\hline Assay throughput & High \\
\hline $\begin{array}{l}\text { Development } \\
\text { stage and } \\
\text { validation status - } \\
\text { further needs }\end{array}$ & Research stage \\
\hline Chemicals tested & \\
\hline $\begin{array}{l}\text { Known } \\
\text { restrictions of the } \\
\text { assay }\end{array}$ & Performance of biochips is variable \\
\hline $\begin{array}{l}\text { Additional } \\
\text { information }\end{array}$ & $\begin{array}{l}62 \text { chemicals were tested on each assay (TTR assay and TBG assay). These } \\
\text { included the natural hormones, PCBs, PBDEs and metabolites, PBA and } \\
\text { halogenated PBAs, halogenated phenols, pharmaceuticals, pesticides and other } \\
\text { potential environmentally relevant chemicals. }\end{array}$ \\
\hline $\begin{array}{l}\text { Are data from } \\
\text { studies publically } \\
\text { available }\end{array}$ & Yes, published literature \\
\hline $\begin{array}{l}\text { Assay included in } \\
\text { OECD DRPs? }\end{array}$ & No, not included in OECD DRP 57 (2006) or DRP 178 (2012) \\
\hline $\begin{array}{l}\text { Proposed/potential } \\
\text { regulatory } \\
\text { purpose }\end{array}$ & $\begin{array}{l}\text { This in vitro assay may be used for TTR and TBG T4 displacements induced by } \\
\text { xenobiotics. Such action by chemicals is hypothesized to increase T4 clearance. }\end{array}$ \\
\hline
\end{tabular}




\section{1.a TransThyretin (TTR) Binding Assays}

\begin{tabular}{|c|c|}
\hline Assay Name & $\begin{array}{l}\text { Fluorescence TTR binding displacement assay using 8-anilino naphthalene } \\
\text { sulfonic acid ammonium salt (ANSA) probe }\end{array}$ \\
\hline $\begin{array}{l}\text { Molecular Initiation } \\
\text { Event or Key Event }\end{array}$ & $\begin{array}{l}\text { Displacement T4 from its binding site on the serum binding proteins TTR or } \\
\text { TBG. }\end{array}$ \\
\hline $\begin{array}{l}\text { Endpoint(s)/ } \\
\text { purpose of the assay }\end{array}$ & $\begin{array}{l}\text { This assay is based on competition of T4-like chemicals with the fluorescent } \\
\text { probe 8-anilino-1-naphtalenesulfonic acid ammonium salt (ANSA). } \\
\text { Flourescence occurs when the ANSA binds the transport proteins. A compound } \\
\text { that competes with TTR or TBG will displace the flourophore from its position } \\
\text { on the protein and reduce the fluorescence. The decrease in fluorescence is the } \\
\text { measure of the potency of the compound to displace T4. }\end{array}$ \\
\hline $\begin{array}{l}\text { Major literature } \\
\text { citations }\end{array}$ & $\begin{array}{l}\text { Montano M. et al., New approaches assess the TTR binding capacity of bio- } \\
\text { activated thyroid hormone disruptors, in Toxicological Sciences, August 1, } 2012\end{array}$ \\
\hline $\begin{array}{l}\text { Tissue, Cells or } \\
\text { Extract utilized in } \\
\text { assay and species } \\
\text { source }\end{array}$ & TTR from human plasma \\
\hline $\begin{array}{l}\text { Laboratories } \\
\text { performing the } \\
\text { work }\end{array}$ & $\begin{array}{l}\text { Centre de Recherche Public - Gabriel Lippmann, Department Environment and } \\
\text { Agro-biotechnologies, 41, rue du Brill, L-4422, Belvaux, Grand Duchy of } \\
\text { Luxembourg }\end{array}$ \\
\hline $\begin{array}{l}\text { Availability of } \\
\text { assay components } \\
\text { for wide use }\end{array}$ & Yes, commercially available \\
\hline Assay throughput & Moderate - High. 96-well plate format, should be suitable for higher \\
\hline $\begin{array}{l}\text { Development stage } \\
\text { and validation } \\
\text { status - further } \\
\text { needs }\end{array}$ & $\begin{array}{l}\text { A new method of extraction is performed before the TTR binding assay in order } \\
\text { to separate fatty acids that disrupt TTR-binding in other assays. } \\
\text { Application of the opimized extraction method (M5) permits calculation of an } \\
\text { IC50 and a binding constant (Kb) which is converted in T4 equivalents (T4eq) in } \\
\text { order to display clear comparison within the methods. }\end{array}$ \\
\hline \multicolumn{2}{|r|}{ (2) } \\
\hline $\begin{array}{l}\text { Known restrictions } \\
\text { of the assay }\end{array}$ & $\begin{array}{l}\text { It should be noted that the assay is performed only with the TTR serum protein } \\
\text { which represents around } 20 \% \text { of transportated thyroid hormones in human serum } \\
\text { whereas the TBG serum protein represents } 75 \% \text {. Two potential } \\
\text { mismeasurements must be avoided: } \\
\text { 1. Interference of flureescent signal by high concentrations of solvent. Solvents } \\
\text { must be kept below the threshold where it binds to the flourophore. } \\
\text { 2. Autoflouescence of solvents and test compounds. MeOH has has been } \\
\text { identified as an appropropriate non-interfering solvent. } \\
\text { 3. Potential interference by autoflourescent xenobiotic chemicals under study. }\end{array}$ \\
\hline $\begin{array}{l}\text { Additional } \\
\text { information }\end{array}$ & $\begin{array}{l}\text { Allows comparison with the previous serum protein binding studies. } \\
\text { A high-throughput assay is available for the simultaneous evaluation of } \\
\text { xenobiotic displacement of T4 binding to both TTR and TBG }\end{array}$ \\
\hline \multicolumn{2}{|l|}{$\begin{array}{l}\text { Are data from } \\
\text { studies publically } \\
\text { available }\end{array}$} \\
\hline $\begin{array}{l}\text { Assay included in } \\
\text { OECD DRPs? }\end{array}$ & No, not included in OECD DRP 57 (2006) or DRP 178 (2012) \\
\hline $\begin{array}{l}\text { Proposed/potential } \\
\text { regulatory purpose }\end{array}$ & $\begin{array}{l}\text { This in vitro assay may be used for TTR and TBG T4 displacements induced by } \\
\text { xenobiotics. Such action by chemicals is hypothesized to increase T4 clearance. }\end{array}$ \\
\hline
\end{tabular}




\begin{tabular}{|c|c|}
\hline Assay Name & $\begin{array}{l}\text { Radioactive TTR-binding/displacement assay. }{ }^{125} \text { I-T4 Displacement from } \\
\text { TTR }\end{array}$ \\
\hline $\begin{array}{l}\text { Molecular } \\
\text { Initiation Event or } \\
\text { Key Event }\end{array}$ & $\begin{array}{l}\text { Displacement T4 from its binding site on the serum binding proteins TTR or } \\
\text { TBG. }\end{array}$ \\
\hline $\begin{array}{l}\text { Endpoint(s)/ } \\
\text { purpose of the } \\
\text { assay }\end{array}$ & $\begin{array}{l}\text { This assay measures the radioactivity of a }{ }^{125} \mathrm{I}-\text { labeled-T4 }\left(\mathrm{L}-3^{\prime}-5^{\prime}-{ }^{125} \mathrm{I} \text {-thyroxine) }\right. \\
\text { which is in competition with the test chemical for binding the TTR serum } \\
\text { transport-protein. Competitive inhibition mechanism exerted by chemicals is } \\
\text { measured - decreasing radioactivity at higher chemical concentrations. The }{ }^{125} \mathrm{I}- \\
\text { T4 is incubated with TTR in the presence of either the test compound or the T4 } \\
\text { (cold T4 as control). Free }{ }^{125} \mathrm{I}-\mathrm{T} 4 \text { and bound- }{ }^{125} \mathrm{I}-\mathrm{T} 4 \text { are separated through a } \\
\text { Biogel P-6PG column. Radioactivity of the bound- }{ }^{125} \mathrm{I}-\mathrm{T} 4 \text { fraction is counted } \\
\text { with a gamma-counter. Corrections are calculated to take into account the } \\
\text { dilution factor. }\end{array}$ \\
\hline $\begin{array}{l}\text { Major literature } \\
\text { citations }\end{array}$ & Hamers et al., Toxicological Sciences, 2006, 92(1), pp. 157-173 \\
\hline $\begin{array}{l}\text { Tissue, Cells or } \\
\text { Extract utilized in } \\
\text { assay and species } \\
\text { source }\end{array}$ & Human TTR (prealbumin from human plasma) \\
\hline $\begin{array}{l}\text { Laboratories } \\
\text { performing the } \\
\text { work }\end{array}$ & $\begin{array}{l}\text { Institute for Environmental Studies, Vrije Universiteit Amsterdam, } 108 \text { HV } \\
\text { Amsterdam, The Netherlands. }\end{array}$ \\
\hline $\begin{array}{l}\text { Availability of } \\
\text { assay components } \\
\text { for wide use }\end{array}$ & Yes, all materials available. \\
\hline Assay throughput & Low to medium \\
\hline $\begin{array}{l}\text { Development } \\
\text { stage and } \\
\text { validation status - } \\
\text { further needs }\end{array}$ & Research stage \\
\hline Chemicals tested & Brominateed flame retardants such as BDEs, TBBPA, HBCDs (31 chemicals). \\
\hline $\begin{array}{l}\text { Known } \\
\text { restrictions of the } \\
\text { assay }\end{array}$ & Test uses radiolabeled $\mathrm{T} 4$. \\
\hline $\begin{array}{l}\text { Additional } \\
\text { information }\end{array}$ & $\begin{array}{l}\text { A high throughput assay is available to test binding to both TTR and TBG serum } \\
\text { proteins. } \\
\text { This assay was performed with OH-PBDEs but could lead to other chemicals } \\
\text { assessment } \\
\text { This assay is a profiling in vitro assay assessing other targets of endocrine } \\
\text { disruption (AR, ER) and leads to PCA analysis. The thyroid target is thus a part } \\
\text { of the analysis }\end{array}$ \\
\hline $\begin{array}{l}\text { Are data from } \\
\text { studies publically } \\
\text { available }\end{array}$ & Yes, published literature \\
\hline $\begin{array}{l}\text { Assay included in } \\
\text { OECD DRPs? }\end{array}$ & No, not included in OECD DRP 57 (2006) or DRP 178 (2012) \\
\hline $\begin{array}{l}\text { Proposed/potential } \\
\text { regulatory } \\
\text { purpose }\end{array}$ & $\begin{array}{l}\text { This in vitro assay may be used for TTR and TBG T4 displacements induced by } \\
\text { xenobiotics. Such action by chemicals is hypothesized to increase T4 clearance. }\end{array}$ \\
\hline
\end{tabular}




\section{BLOCK \#4 ASSAYS}

\section{METABOLISM AND EXCRETION}

101. This block contains assays with a potential to evaluate disruption of thyroid hormone function by examining the ability of xenobiotics to interfere with the enzymatic systems responsible for deiodination, glucuronidation and sulfaction of the hormone.

\subsection{Deiodinase Activity Assays}

\begin{tabular}{|c|c|}
\hline $\begin{array}{l}\text { Block } 4 \text { Assays - } \\
\text { DI-1 }\end{array}$ & Radioactive deiodinase assay / Liver 5'-deiodinase type 1 (IDI-1) assay \\
\hline $\begin{array}{l}\text { Molecular Initiation } \\
\text { Event or Key Event }\end{array}$ & Inhibition of DI-1 \\
\hline $\begin{array}{l}\text { Endpoint(s)/ } \\
\text { purpose of the assay }\end{array}$ & $\begin{array}{l}\text { This assay assesses the ID-1 activity without and with the test compounds } \\
\text { (competitive inhibition) by measuring the radioactivity due to }{ }^{125} \text { I-rT3 substrate. }\end{array}$ \\
\hline $\begin{array}{l}\text { Major literature } \\
\text { citations }\end{array}$ & $\begin{array}{l}\text { Schoenmakers et al. 1992, citation; Freyberger \& Ahr, 2006, Toxicology, 217, } \\
\text { 169-175 }\end{array}$ \\
\hline $\begin{array}{l}\text { Tissue, Cells, } \\
\text { Extract utilized in } \\
\text { assay and species } \\
\text { source }\end{array}$ & Human, rat, mouse, dog, rabbit, cow, pig, sheep chicken and others \\
\hline $\begin{array}{l}\text { Laboratories } \\
\text { performing the work }\end{array}$ & T. Visser's lab (Netherlands), Bayer HealthCare (Germany) \\
\hline $\begin{array}{l}\text { Availability of assay } \\
\text { components for } \\
\text { wide use }\end{array}$ & $\begin{array}{l}\text { Not all components are publically available. (Co-) substrates and buffer salts } \\
\text { are commercially available. As DI- } 1 \text { source a } 10,000 \mathrm{x} \text { g supernatant from rat } \\
\text { liver or from liver of other species is used. Accordingly only a human source } \\
\text { for ID- } 1 \text { may not readily be available. }\end{array}$ \\
\hline Assay throughput & Low to medium \\
\hline $\begin{array}{l}\text { Development stage } \\
\text { and validation status }\end{array}$ & Research stage, but can be used in the past and retrospective validation. \\
\hline Chemicals tested & $\begin{array}{l}\text { Cyclic thiourea derivatives like substituted thiouracil and mercaptoimidazole } \\
\text { derivatives, ethylenethiourea and the non-cyclic N,N,N',N'- } \\
\text { tetramethylthiourea. }\end{array}$ \\
\hline $\begin{array}{l}\text { Known restrictions } \\
\text { of the assay }\end{array}$ & Variation in assay parameters from paper to paper \\
\hline $\begin{array}{l}\text { Additional } \\
\text { information }\end{array}$ & $\begin{array}{l}\text { Methodology has been adopted for use with thyroid ex vivo. A non-radioactive } \\
\text { methodology could be developed: Instead of the release of radiolabeled iodide } \\
\text { the formation of 3,3'-diiodothyronine could be measured e.g., by HPLC } \\
\text { analysis }\end{array}$ \\
\hline \multicolumn{2}{|l|}{$\begin{array}{l}\text { Are data from } \\
\text { studies publically } \\
\text { available }\end{array}$} \\
\hline $\begin{array}{l}\text { Assay included in } \\
\text { OECD DRPs? }\end{array}$ & $\begin{array}{l}\text { Yes, assay included in OECD DRP } 57 \text { (OECD, 2006) or DRP } 178 \text { (OECD, } \\
\text { 2012) }\end{array}$ \\
\hline $\begin{array}{l}\text { Proposed/potential } \\
\text { regulatory purpose }\end{array}$ & $\begin{array}{l}\text { In vitro screen for ID-1 inhibitors. Ex vivo parameter for OECD in vivo } \\
\text { protocols relating thyroid effects to changes in liver type } 1 \text { deiodination }\end{array}$ \\
\hline
\end{tabular}




\begin{tabular}{|c|c|}
\hline $\begin{array}{l}\text { Block } 4 \text { Assays } \\
\text { DI-2 }\end{array}$ & HPLC based deiodinase assay \\
\hline $\begin{array}{l}\text { Molecular } \\
\text { Initiation Event or } \\
\text { Key Event }\end{array}$ & $\begin{array}{l}\text { Inhibition of deiodinase activity by disrupting chemicals with decrease of } \\
\text { circulating thyroid active hormone (T3) as consequence. }\end{array}$ \\
\hline $\begin{array}{l}\text { Endpoint(s)/ } \\
\text { purpose of the } \\
\text { assay }\end{array}$ & $\begin{array}{l}\text { This assay assesses DI-1 activity without and with the test compounds and is } \\
\text { based on competitive inhibition with iodoacetate, a well known DI- } 1 \text { inhibitor. } \\
\text { Formation of T3 and rT3 in the presence and absece of test compound is } \\
\text { measured. }\end{array}$ \\
\hline $\begin{array}{l}\text { Major literature } \\
\text { citations }\end{array}$ & Butt et al., 2011. Toxicological Sciences 124(2), 339-347 \\
\hline $\begin{array}{l}\text { Tissue, Cells, } \\
\text { Extract utilized in } \\
\text { assay and species } \\
\text { source }\end{array}$ & Human Type I Deiodinase from Human liver microsomes \\
\hline $\begin{array}{l}\text { Laboratories } \\
\text { performing the } \\
\text { work }\end{array}$ & $\begin{array}{l}\text { Stapleton, Nicholas School of the Environment, Duke University, Durham, NC } \\
27708\end{array}$ \\
\hline $\begin{array}{l}\text { Availability of } \\
\text { assay components } \\
\text { for wide use }\end{array}$ & All materials used for the assay are available \\
\hline Assay throughput & Low to medium \\
\hline $\begin{array}{l}\text { Development } \\
\text { stage and } \\
\text { validation status }\end{array}$ & Research stage \\
\hline Chemicals tested & BDE 99 and its hydroxyl-derivates, tribromophenol, TBBPA, Triclosan. T \\
\hline $\begin{array}{l}\text { Known } \\
\text { restrictions of the } \\
\text { assay }\end{array}$ & Human microsomes required? \\
\hline $\begin{array}{l}\text { Additional } \\
\text { information }\end{array}$ & $\begin{array}{l}\text { Chemicals used are the authors concluded on possible several mechanism of } \\
\text { action, and stated about non-competitive inhibition that should be considered for } \\
\text { further work. } \\
\text { The study allows ranking of the test chemicals. The experiments show that } \\
\text { inhibition generally increased with increasing halogen molecular weight } \\
(\mathrm{I}>\mathrm{Br}>\mathrm{Cl}>\mathrm{F})\end{array}$ \\
\hline $\begin{array}{l}\text { Are data from } \\
\text { studies publically } \\
\text { available }\end{array}$ & Yes, published manuscript \\
\hline $\begin{array}{l}\text { Assay included in } \\
\text { OECD DRPs? }\end{array}$ & No, not included in OECD DRP 57 (OECD, 2006) or DRP 178 (OECD, 2012) \\
\hline $\begin{array}{l}\text { Proposed/potential } \\
\text { regulatory } \\
\text { purpose }\end{array}$ & In vitro screen for deiodinase type-1 inhibitors. \\
\hline
\end{tabular}




\begin{tabular}{|l|l|}
\hline $\begin{array}{l}\text { Block 4 Assays } \\
\text { DI-3 }\end{array}$ & Colorimetric method for assessing deiodinases activities \\
\hline $\begin{array}{l}\text { Molecular } \\
\text { Initiation Event or } \\
\text { Key Event }\end{array}$ & Inhibition of DI-1 activity \\
\hline $\begin{array}{l}\text { Endpoint(s)/ } \\
\text { purpose of the } \\
\text { assay }\end{array}$ & $\begin{array}{l}\text { Modulation of ID1, ID2 and potentially ID3 activities. Measures free iodine based } \\
\text { on the Sandell-Kolthoff reaction. }\end{array}$ \\
\hline $\begin{array}{l}\text { Major literature } \\
\text { citations }\end{array}$ & Renko et al., 2012, Endocrinology. 153, 2506-13. \\
\hline $\begin{array}{l}\text { Tissue, Cells, } \\
\text { Extract utilized in } \\
\text { assay and species } \\
\text { source }\end{array}$ & $\begin{array}{l}\text { This assay uses microsomal fractions from fresh mice livers and reveal D1 and } \\
\text { cell culture could be done but it is still limited to rich sources of enzymatic } \\
\text { activity. }\end{array}$ \\
\hline $\begin{array}{l}\text { Laboratories } \\
\text { performing the } \\
\text { work }\end{array}$ & Kohrle lab, Germany \\
\hline $\begin{array}{l}\text { Availability of } \\
\text { assay components } \\
\text { for wide use }\end{array}$ & Mentially D3). Micromal fractions from ther tisues or \\
\hline Assay throughput & Medium. Developed in 96 well plates and is suitable for high throughput \\
\hline $\begin{array}{l}\text { Development } \\
\text { stage and } \\
\text { validation status }\end{array}$ & Research Stage \\
\hline Chemicals tested & MMI, PTU, iapoanoic acid, T4. \\
\hline $\begin{array}{l}\text { Known } \\
\text { restrictions of the } \\
\text { assay }\end{array}$ & $\begin{array}{l}\text { The colorimetric based method is a promising alternative to the radioactive iodine } \\
\text { substrate methods but is still limited in sensitivity and restricted to rich sources of } \\
\text { enzymatic activity. }\end{array}$ \\
\hline $\begin{array}{l}\text { Additional } \\
\text { information }\end{array}$ & A patent application deposit is in progress \\
\hline $\begin{array}{l}\text { Are data from } \\
\text { studies publically } \\
\text { available }\end{array}$ & No \\
\hline $\begin{array}{l}\text { Assay included in } \\
\text { OECD DRPs? }\end{array}$ & No, not included in OECD DRP 57 (OECD, 2006) or DRP 178 (OECD, 2012) \\
\hline $\begin{array}{l}\text { Proposed/potential } \\
\text { regulatory } \\
\text { purpose }\end{array}$ & $\begin{array}{l}\text { Detetction of substances that alter metabolism of hormones via deiodination } \\
\text { pathways }\end{array}$ \\
\hline
\end{tabular}




\subsection{Glucuronidation Assays}

102. Glucuronidation assays that study thyroid disrupters are mainly in vivo assays. Therefore, they are not mentioned in this document as we aim to focus on in vitro assessment. Several in vivo assays suggest that chemicals that increase UDP-glucuronosyltransferases (UGTs) increase T4 glucuronidation, and lead to a reduction in serum T4 and increase TSH. The assays below describe an approach to assess glucuronidation pathways in vitro but no chemicals have been tested. These assays with further development may be useful for future assessment of thyroid disrupting compounds.

\begin{tabular}{|c|c|}
\hline $\begin{array}{l}\text { Block } 4 \text { Assay } \\
\text { UGT-1 }\end{array}$ & Fluorescence based Ex vivo Liver glucuronidation assay \& microsomes \\
\hline $\begin{array}{l}\text { Molecular } \\
\text { Initiation Event or } \\
\text { Key Event }\end{array}$ & Liver glucuronidation ex vivo; 1-naphthol as model substrate for T4 \\
\hline $\begin{array}{l}\text { Endpoint }(\mathrm{s}) / \\
\text { purpose of the } \\
\text { assay }\end{array}$ & $\begin{array}{l}\text { In liver microsomes, 1-naphtol is used as model substrate for T4 and } \\
\text { glucuronidation reaction is performed through UGT microsomal suspension. The } \\
\text { fluorescence of the naphtol-glucuronide is measured in spectrofluorometer. }\end{array}$ \\
\hline $\begin{array}{l}\text { Major literature } \\
\text { citations }\end{array}$ & Bock, 1974. Naunyn-Schmiedberg's Arch. Pharmacol. 283-330. \\
\hline $\begin{array}{l}\text { Tissue, Cells, } \\
\text { Extract utilized in } \\
\text { assay and species } \\
\text { source }\end{array}$ & Liver extracts from Rat, Dog, Mouse, Monkey \\
\hline $\begin{array}{l}\text { Laboratories } \\
\text { performing the } \\
\text { work }\end{array}$ & Bayer HealthCare, Germany \\
\hline $\begin{array}{l}\text { Availability of } \\
\text { assay components } \\
\text { for wide use }\end{array}$ & No \\
\hline Assay throughput & Low to medium \\
\hline $\begin{array}{l}\text { Development } \\
\text { stage and } \\
\text { validation status }\end{array}$ & Use in research and development. Retrospective validation may be possible. \\
\hline Chemicals tested & None \\
\hline $\begin{array}{l}\text { Known } \\
\text { restrictions of the } \\
\text { assay }\end{array}$ & Not tested in vitro - only used for in vivo/ex vivo studies to date \\
\hline $\begin{array}{l}\text { Additional } \\
\text { information }\end{array}$ & Assay used ex vivo tissue by many groups over decades \\
\hline \multirow{2}{*}{$\begin{array}{l}\text { Are data from } \\
\text { studies publically } \\
\text { available }\end{array}$} & $\begin{array}{l}\text { Yes: } \\
\text { Phenobarbital \& 3-methylcholanthrene (Perrone, C.E., Ahr, H.-J., Duan, J.D., } \\
\text { Jeffrey, A.M., Schmidt, U., Williams, G.M., \& Enzmann, H.H. (2004) Embryonic } \\
\text { turkey liver: activities of biotransforming enzymes and activities of DNA-reactive } \\
\text { carcinogens. Arch. Toxicol. 78, 589-598 }\end{array}$ \\
\hline & $\begin{array}{l}\text { Flutamide (Andrews, P., Freyberger, A., Hartmann, E., Eiben, R., Loof, I., } \\
\text { Schmidt, U., Temerowski, M., \& Becka, M. (2001) Feasibility and potential gains } \\
\text { of enhancing the subacute rat study protocol (OECD test guideline no. 407) by } \\
\text { additional parameters selected to determine endocrine modulation. A pre- }\end{array}$ \\
\hline
\end{tabular}




\begin{tabular}{|l|l|}
\hline & $\begin{array}{l}\text { validation study to determine endocrine-mediated effects of the antiandrogenic } \\
\text { drug flutamide. Arch. Toxicol. 75, 65-73) }\end{array}$ \\
& $\begin{array}{l}\text { Ethinylestradiol (Andrews, P., Freyberger, A., Hartmann, E., Eiben, R., Loof, I., } \\
\text { Schmidt, U., Temerowski, M., Folkerts, A., Stahl, B., \& Kayser, M. (2002) } \\
\text { Sensitive detection of the endocrine effects of the estrogen analogue } \\
\text { ethinylestradiol using a modified enhanced subacute rat study protocol (OECD } \\
\text { test guideline no. 407). Arch. Toxicol. 76, 194-202) } \\
\text { p,p'-DDE (Freyberger, A., Ellinger-Ziegelbauer, H. \& Krötlinger, F. (2007) } \\
\text { Evaluation of the rodent Hershberger bioassay: Testing of coded chemicals and } \\
\text { supplementary molecular-biological and biochemical investigations. Toxicology } \\
\text { 239, 77-88) }\end{array}$ \\
\hline $\begin{array}{l}\text { Assay included in } \\
\text { OECD DRPs? }\end{array}$ & $\begin{array}{l}\text { Yes, included in OECD DRP 57 (OECD, 2006) or DRP 178 (OECD, 2012) in } \\
\text { vivo protocols }\end{array}$ \\
\hline $\begin{array}{l}\text { Proposed/potential } \\
\text { regulatory } \\
\text { purpose }\end{array}$ & $\begin{array}{l}\text { Ex vivo parameter for OECD in vivo protocols relating thyroid effects to } \\
\text { increased metabolic disposition (glucuronidation) of thyroid hormone }\end{array}$ \\
\hline
\end{tabular}




\begin{tabular}{|c|c|}
\hline Assay Name & $\begin{array}{l}\text { Chromatography/mass spectrometry (LC/MS) glucuronidation assay using } \\
\text { microsomes or recombinant UGTs }\end{array}$ \\
\hline $\begin{array}{l}\text { Molecular } \\
\text { Initiation Event or } \\
\text { Key Event }\end{array}$ & Liver glucuronidation of $\mathrm{T} 4$ and $\mathrm{T} 3$ \\
\hline $\begin{array}{l}\text { Endpoint }(\mathrm{s}) / \\
\text { purpose of the } \\
\text { assay }\end{array}$ & $\begin{array}{l}\text { The method consists in the incubation of either T4 or T3 with liver microsomes } \\
\text { or recombinant human UGTs. Following separation and purification the mixture } \\
\text { is analysed by liquid chromatography/mass spectrometry (LC/MS). Acyl- and } \\
\text { Phenolic- Glucuronides are separated and peaks identities confirmed.This } \\
\text { separation allows also to confirm the structures by NMR Analysis of T4 Phenolic } \\
\text { Glucuronides } \\
\text { This assay performs multiple tests: Separation of T4 and T3 Glucuronides by } \\
\text { LC/MS; formation of T4 Glucuronides is measured and separated glucuronides } \\
\text { structures confirmed; classification of enzymes' activities is performed by } \\
\text { comparing peak areas ratios }\end{array}$ \\
\hline $\begin{array}{l}\text { Major literature } \\
\text { citations }\end{array}$ & Tong et al., Drug Metabolism and Disposition, 2007, 35:2203-2210. \\
\hline $\begin{array}{l}\text { Tissue, Cells or } \\
\text { Extract utilized in } \\
\text { assay and species } \\
\text { source }\end{array}$ & Human, rat, mouse, dog, monkey (for species differences assessment) \\
\hline $\begin{array}{l}\text { Laboratories } \\
\text { performing the } \\
\text { work }\end{array}$ & $\begin{array}{l}\text { Biotransformation Division (Z.T., H.L, A.C) and Discovery Analytical } \\
\text { Chemistry (I.G., O.M.), Wyeth Research, Collegeville, Pennsylvania }\end{array}$ \\
\hline $\begin{array}{l}\text { Availability of } \\
\text { assay components } \\
\text { for wide use }\end{array}$ & Yes \\
\hline Assay throughput & Low \\
\hline $\begin{array}{l}\text { Development } \\
\text { stage and } \\
\text { validation status - } \\
\text { further needs }\end{array}$ & Research stage \\
\hline Chemicals tested & BDE-47, BDE-99 \\
\hline $\begin{array}{l}\text { Known } \\
\text { restrictions of the } \\
\text { assay }\end{array}$ & $\begin{array}{l}\text { Induction of liver glucuronidation through foreign compounds resulting in an } \\
\text { increased metabolic disposition of thyroid hormones. This can only be addressed } \\
\text { in vivo or in hepatocyte culture. This important aspect is not covered by this } \\
\text { assay. Expensive technology }\end{array}$ \\
\hline $\begin{array}{l}\text { Additional } \\
\text { information }\end{array}$ & $\begin{array}{l}\text { This study has multiple benefits including it is entirely in vitro; T4- or T3- } \\
\text { Glucuronides are easily separated by LC/MS; assay is reliable and reproducible; } \\
\text { uses human recombinant enzymes; elucidates role of different enzyme subtypes }\end{array}$ \\
\hline $\begin{array}{l}\text { Are data from } \\
\text { studies publically } \\
\text { available }\end{array}$ & \\
\hline $\begin{array}{l}\text { Assay included in } \\
\text { OECD DRPs? }\end{array}$ & No, not included in OECD DRP 57 (2006) or DRP 178 (2012) \\
\hline $\begin{array}{l}\text { Proposed/potential } \\
\text { regulatory } \\
\text { purpose }\end{array}$ & $\begin{array}{l}\text { In vitro protocols relating thyroid effects to increased metabolic disposition } \\
\text { (glucuronidation) of thyroid hormone. This assay is suitable as a startpoint for } \\
\text { TDs assessment and be compared to results from in vivo studies. }\end{array}$ \\
\hline
\end{tabular}




\subsection{Sulfation Assays}

\begin{tabular}{|c|c|}
\hline Assay Name & Inhibition of thyroid hormone sulfation \\
\hline $\begin{array}{l}\text { Molecular } \\
\text { Initiation Event or } \\
\text { Key Event }\end{array}$ & Inhibition of sulfotransferase \\
\hline $\begin{array}{l}\text { Endpoint(s)/ } \\
\text { purpose of the } \\
\text { assay }\end{array}$ & This assay measures the SULT activity calculated in percentage of control. \\
\hline $\begin{array}{l}\text { Major literature } \\
\text { citations }\end{array}$ & $\begin{array}{l}\text { Schuur et al., inhibition of thyroid hormone sulfation by hydroxylated } \\
\text { metabolites of polychlorinated biphenyls, Chemico-Biological interactions } 109 \\
\text { (1998), 293-297 }\end{array}$ \\
\hline $\begin{array}{l}\text { Tissue, Cells or } \\
\text { Extract utilized in } \\
\text { assay and species } \\
\text { source }\end{array}$ & Rat liver, Human SULT \\
\hline $\begin{array}{l}\text { Laboratories } \\
\text { performing the } \\
\text { work }\end{array}$ & $\begin{array}{l}\text { Department of Toxicology, Agriculture University Wageningen, PO Box } 8000 \text {, } \\
6700 \text { EA, Wageningen, The Netherlands. }\end{array}$ \\
\hline $\begin{array}{l}\text { Availability of } \\
\text { assay components } \\
\text { for wide use } \\
\text { (public or } \\
\text { commercial, or } \\
\text { not available) }\end{array}$ & \\
\hline $\begin{array}{l}\text { Assay throughput } \\
\text { (high, medium, } \\
\text { low) }\end{array}$ & Low \\
\hline $\begin{array}{l}\text { Development } \\
\text { stage and } \\
\text { validation status - } \\
\text { further needs }\end{array}$ & \\
\hline Chemicals tested & PCBs \\
\hline $\begin{array}{l}\text { Known } \\
\text { restrictions of the } \\
\text { assay }\end{array}$ & $\begin{array}{l}\text { The protocol does not specify if SULT activity was assessed depending on } \\
\text { different DMSO concentrations (without PCBs) in order to assess solvent effect } \\
\text { that could decrease the enzyme activity and thus lead to mismeasurements, i.e. } \\
\text { inconclusive inhibited activity. Nevertheless, the article specifies not to exceed } \\
1 \% \text { DMSO, which may underlie this solvent effect has been assessed but it } \\
\text { remains unclear. Also, the use of rat livers may involve other enzymes for T2 } \\
\text { metabolism. V79 cells transfected with the human SULT1A1 provide } \\
\text { information only for this type of enzyme. }\end{array}$ \\
\hline $\begin{array}{l}\text { Additional } \\
\text { information }\end{array}$ & $\begin{array}{l}\text { The assay also includes the use of V79 cells transfected with the human } \\
\text { SULT1A1 which more likely to provide conclusion for human health. } \\
\text { Nevertheless, only one type of SULT is assessed here. }\end{array}$ \\
\hline \multicolumn{2}{|l|}{$\begin{array}{l}\text { Are data from } \\
\text { studies publically } \\
\text { available }\end{array}$} \\
\hline $\begin{array}{l}\text { Assay included in } \\
\text { OECD DRP } 57 \\
\text { (OECD, 2006) or }\end{array}$ & No \\
\hline
\end{tabular}


ENV/JM/MONO(2014)23

DRP 178 (OECD,

2012)

Proposed/potential regulatory

Chemical potency assessment in SULT inhibition, in relation with thyroid

purpose hormone disruption. 


\section{BLOCK \#5 ASSAYS}

\section{LOCAL CELLULAR CONCENTRATIONS}

103. This block contains assays with a potential to evaluate disruption of thyroid hormone function by examining the ability of xenobiotics to interfere with the function of tissue and cell specific membrane transporter proteins for thyroid hormone or by interfering with peripheral deiodination of the hormone.

\subsection{Thyroid Transmembrane Transporter Assays}

\begin{tabular}{|c|c|}
\hline Assay Name & Transient Transfection T3 uptake assay \\
\hline $\begin{array}{l}\text { Molecular } \\
\text { Initiation Event or } \\
\text { Kev Event }\end{array}$ & $\begin{array}{l}\text { T3 is actively transported across the plasma membrane by Monocarboxylate } \\
\text { Transporter } 10 \text { (MCT10) and MCT8 (or other transporters) }\end{array}$ \\
\hline $\begin{array}{l}\text { Endpoint(s)/ } \\
\text { purpose of the } \\
\text { assay }\end{array}$ & $\begin{array}{l}{ }^{125} \text { I-labelled T3 accumulates within cultured cells that have been transiently } \\
\text { transfected with plasmids expressing the human gene for a transporter (MCT } 8 \text { or } \\
\text { MCT10). After incubation with labeled T3 for a short period of time (about } 10 \\
\text { min) cells are washed and lysed with } \mathrm{NaOH} \text {. Lysate is counted to reveal T3 } \\
\text { uptake. Radioactivity in this lysate indicates transporter activity. This value } \\
\text { should be corrected for non-specific uptake of radioactivity in the lysate. This } \\
\text { can be measured by incubating the cells with radiolabeled T3 in the presence of } \\
200-1000 \text { fold excess unlabeled T3. }\end{array}$ \\
\hline $\begin{array}{l}\text { Major literature } \\
\text { citations }\end{array}$ & $\begin{array}{l}\text { Friesema et al, (2003 J.Biol.Chem. 278(41), 40128-40135; Friesema et al,. } \\
\text { (2008). Mol Endocrinol 22(6), 1357-69; Kinne et al. 2009 J Molec Endocrinol. } 43 \\
\text { 263-271 }\end{array}$ \\
\hline $\begin{array}{l}\text { Tissue, Cells or } \\
\text { Extract utilized in } \\
\text { assay and species } \\
\text { source }\end{array}$ & $\begin{array}{l}\text { Green monkey cell line COS1 transiently transfected to express transporter of } \\
\text { interest. } \\
\text { Dog MCDK1 cells stably transfected with wild type or mutant human MCT8 }\end{array}$ \\
\hline $\begin{array}{l}\text { Laboratories } \\
\text { performing the } \\
\text { work }\end{array}$ & $\begin{array}{l}\text { Theo Visser's lab, Erasmus University, Netherlands } \\
\text { Josef Kohrle's lab, Humboldt University, Berlin }\end{array}$ \\
\hline $\begin{array}{l}\text { Availability of } \\
\text { assay components } \\
\text { for wide use }\end{array}$ & $\begin{array}{l}\text { Public: The cell line used in this study can be ordered from ATCC but requires } \\
\text { biocontainment level } 2 \text { due to stable expression of large T from SV } 40 \text {. However, } \\
\text { other cell lines could be adapted to the assay but T3 uptake capability would need } \\
\text { to be characterized.would need to be characterized. }\end{array}$ \\
\hline Assay throughput & Low - Medium \\
\hline $\begin{array}{l}\text { Development } \\
\text { stage and } \\
\text { validation status - } \\
\text { further needs }\end{array}$ & Research; requires further standardization/validation. \\
\hline Chemicals tested & Sulphobromothalein (but it could be used to sc \\
\hline $\begin{array}{l}\text { Known } \\
\text { restrictions of } \\
\text { assay }\end{array}$ & Use of radioactivity \\
\hline $\begin{array}{l}\text { Additional } \\
\text { information }\end{array}$ & $\begin{array}{l}\text { Co-transfection with plasmids expressing human micro-crystallin - an } \\
\text { intracellular protein that sequesters TH molecules - enhances the read-out from } \\
\text { this assay as it limits the rate of efflux of labeled TH. }\end{array}$ \\
\hline Are data from & Data from these studies are only publicly available through the published \\
\hline
\end{tabular}




\begin{tabular}{|l|l|}
\hline $\begin{array}{l}\text { studies publically } \\
\text { available }\end{array}$ & $\begin{array}{l}\text { literature. The authors have not been approached to see if they will provide the } \\
\text { raw data. }\end{array}$ \\
\hline $\begin{array}{l}\text { Assay included in } \\
\text { OECD DRPs? }\end{array}$ & No, not included in OECD DRP 57 (2006) or DRP 178 ( 2012) \\
\hline $\begin{array}{l}\text { Proposed/potential } \\
\text { regulatory } \\
\text { purpose }\end{array}$ & $\begin{array}{l}\text { Humans or mice that lack a functional gene for MCT8 show notable disturbances } \\
\text { in thyroid hormone physiology and deficits in normal brain development. } \\
\text { Substances which impair the activity of MCT8 may cause developmental } \\
\text { impairments by blocking TH uptake by target cells at critical periods of } \\
\text { development. This assay can rapidly identify substances with such activity. }\end{array}$ \\
\hline
\end{tabular}




\begin{tabular}{|c|c|}
\hline Assay Name & Transient Transfection Thyroxine Uptake Assay \\
\hline $\begin{array}{l}\text { Molecular } \\
\text { Initiation Event or } \\
\text { Key Event }\end{array}$ & $\begin{array}{l}\text { Thyroxine is actively transported across the plasma membrane and probably } \\
\text { across the blood brain barrier by OATP1c1. Blocking the activity of this } \\
\text { molecule is likely to lead to hypothyroidism in the brain and liver. }\end{array}$ \\
\hline $\begin{array}{l}\text { Endpoint(s)/ } \\
\text { purpose of the } \\
\text { assay }\end{array}$ & $\begin{array}{l}{ }^{125} \text { I-labelled T4 accumulates within cultured cells that have been transiently } \\
\text { transfected with plasmids expressing the rat gene for a transporter OATP1c1 } \\
\text { (gene Slco } 1 \mathrm{c} 1 \text { ). After incubation with labelled T4 until equilibrium is reached } \\
\text { (about } 10 \mathrm{~min} \text { ) cells are washed and lysed with } 0.5 \% \text { Triton X100. Lysate is } \\
\text { counted to reveal T3 uptake. Radioactivity in this lysate - less radioactivity in } \\
\text { blank (from cells with no plasmid - Comment this could also by incubations with } \\
\text { labelled T4 plus } 200 \text { fold or more excess of cold T3) - indicates transporter } \\
\text { activity. }\end{array}$ \\
\hline $\begin{array}{l}\text { Major literature } \\
\text { citations }\end{array}$ & $\begin{array}{l}\text { Westholm, D. E., Stenehjem, D. D., Rumbley, J. N., Drewes, L. R. and } \\
\text { Anderson, G. W. (2009). Competitive inhibition of organic anion transporting } \\
\text { polypeptide 1c1-mediated thyroxine transport by the fenamate class of } \\
\text { nonsteroidal antiinflammatory drugs. Endocrinology 150(2), 1025-32, } \\
\text { 10.1210/en.2008-0188. }\end{array}$ \\
\hline $\begin{array}{l}\text { Tissue, Cells or } \\
\text { Extract utilized in } \\
\text { assay and species } \\
\text { source }\end{array}$ & $\begin{array}{l}\text { Human embryonic kidney cells (HEK) } 293 \text { transiently transfected to express } \\
\text { OATP1c1 }\end{array}$ \\
\hline $\begin{array}{l}\text { Laboratories } \\
\text { performing the } \\
\text { work }\end{array}$ & $\begin{array}{l}\text { Grant Anderson's, Department of Pharmacy Practice and Pharmaceutical } \\
\text { Sciences, University of Minnesota Duluth, Duluth, Minnesota } 55812\end{array}$ \\
\hline $\begin{array}{l}\text { Availability of } \\
\text { assay components } \\
\text { for wide use } \\
\text { (public or } \\
\text { commercial, or } \\
\text { not available) } \\
\end{array}$ & $\begin{array}{l}\text { Public: cells can be ordered from ATCC; expression plasmids of the ORF of the } \\
\text { full human gene are commercially available. }\end{array}$ \\
\hline $\begin{array}{l}\text { Assay throughput } \\
\text { (high, medium, } \\
\text { low) }\end{array}$ & Low - Medium \\
\hline $\begin{array}{l}\text { Development } \\
\text { stage and } \\
\text { validation status - } \\
\text { further needs }\end{array}$ & Research; requires further standardization/validation. \\
\hline Chemicals tested & $\begin{array}{l}\text { Fenamic Acid }(\text { IC50 }=25 \mu \mathrm{M}) \text {; Diclofenac }(\text { IC50 }=4 \mu \mathrm{M}) ; \text { Meclofenamic Acid } \\
(\text { IC50 = } 3 \mu \mathrm{M}) \text {; Iopanoic Acid }(\text { IC50 }=3 \mu \mathrm{M}) ; \text { Iodocyanine Green }(\text { IC50 }=0.1 \\
\mu \mathrm{M}) ; \text { Phenytoin }(\text { IC50 }=26 \mu \mathrm{M})\end{array}$ \\
\hline $\begin{array}{l}\text { Known } \\
\text { restrictions of the } \\
\text { assay }\end{array}$ & Use of of radioactivity. \\
\hline $\begin{array}{l}\text { Additional } \\
\text { information }\end{array}$ & $\begin{array}{l}\text { The authors also report using a preparation of rat brain microvasculature but far } \\
\text { too much effort is required for this preparation for a screening assay. }\end{array}$ \\
\hline $\begin{array}{l}\text { Are data from } \\
\text { studies publically } \\
\text { available }\end{array}$ & $\begin{array}{l}\text { Data from these studies are only publicly available through the published } \\
\text { literature. The authors have not been approached to see if they will provide the } \\
\text { raw data. }\end{array}$ \\
\hline $\begin{array}{l}\text { Assay included in } \\
\text { OECD DRP } 57\end{array}$ & 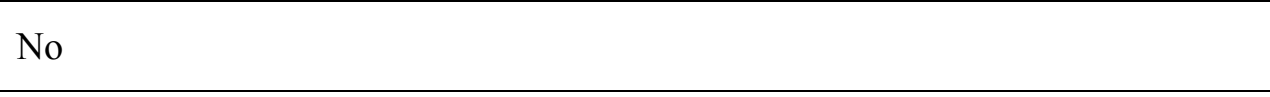 \\
\hline
\end{tabular}




\begin{tabular}{|l|l|}
\hline $\begin{array}{l}\text { (OECD, 2006) or } \\
\text { DRP 178 (OECD, }\end{array}$ & \\
\hline 2012) & $\begin{array}{l}\text { The transport of thyroxine across cell membranes is clearly important for the } \\
\text { secretion of thyroid hormone from the thyroid gland, for uptake of thyroxine into } \\
\text { target tissues and across the blood brain barrier. Substances which impair this } \\
\text { process could potentially disrupt thyroid hormone-mediated processes such as } \\
\text { neurodevelopment. However, there is no known lack-of-function mutant in } \\
\text { humansand experimental knock-out mice show normal neurological phenotype } \\
\text { (Mayerl, et al., 2012. Endocrinology. 15:1528-37). Moreover, there are no } \\
\text { purposed }\end{array}$ \\
$\begin{array}{l}\text { puamples of substances that specifically inhibit the function of this transporter } \\
\text { resulting in clear, thyroid hormone-related effect preventing the assessment of } \\
\text { toxicity resulting from this MOA. Consequently, these data suggest that this } \\
\text { modality is not a high priority for developing into a screening assay. }\end{array}$
\end{tabular}




\begin{tabular}{|c|c|}
\hline Assay Name & T3/T4 cellular uptake assay \\
\hline $\begin{array}{l}\text { Molecular } \\
\text { Initiation Event or } \\
\text { Key Event }\end{array}$ & Transmembrane uptake of thyroid hormones (either T3 or T4) into cell. \\
\hline $\begin{array}{l}\text { Endpoint }(\mathrm{s}) / \\
\text { purpose of the } \\
\text { assay }\end{array}$ & $\begin{array}{l}\text { This assay measures the inhibition of thyroid hormone transfer from extracellular } \\
\text { to intracellular compartments to determine the potential chemical-induced } \\
\text { blockade of all TH (T4, T3 or rT3 depending on radio-labelled ligand used) } \\
\text { transporter activity present in the cell used. }\end{array}$ \\
\hline $\begin{array}{l}\text { Major literature } \\
\text { citations }\end{array}$ & $\begin{array}{l}\text { Among others: Kragie, L. and Doyle, D. (1992). Benzodiazepines inhibit } \\
\text { temperature-dependent L-[125I]triiodothyronine accumulation into human liver, } \\
\text { human neuroblast, and rat pituitary cell lines. Endocrinology 130(3), 1211-6; } \\
\text { Lim, C. F., Loidl, N. M., Kennedy, J. A., Topliss, D. J. and Stockigt, J. R. (1996). } \\
\text { Drug effects on triiodothyronine uptake by rat anterior pituitary cells in vitro. } \\
\text { Experimental and clinical endocrinology \& diabetes : 104(2), 151-7, 10.1055/s- } \\
\text { 0029-1211437; } \\
\text { Movius, E. G., Phyillaier, M. M. and Robbins, J. (1989). Phloretin inhibits } \\
\text { cellular uptake and nuclear receptor binding of triiodothyronine in human hep G2 } \\
\text { hepatocarcinoma cells. Endocrinology 124(4), 1988-97. }\end{array}$ \\
\hline $\begin{array}{l}\text { Tissue, Cells or } \\
\text { Extract utilized in } \\
\text { assay and species } \\
\text { source }\end{array}$ & $\begin{array}{l}\text { Various primary cells (rat pituitary, cardiomyocytes from infant rats, human red } \\
\text { blood cells) HepG2 Cells (human liver hepatoma); GH3-L (rat pituitary cells); } \\
\text { SHSY5Y (a subclone of SK-N-SH; neuroblastoma cell line). }\end{array}$ \\
\hline $\begin{array}{l}\text { Laboratories } \\
\text { performing the } \\
\text { work }\end{array}$ & Many \\
\hline $\begin{array}{l}\text { Availability of } \\
\text { assay components } \\
\text { for wide use } \\
\text { (public or } \\
\text { commercial, or } \\
\text { not available) }\end{array}$ & $\begin{array}{l}\text { The parent cell lines (HEPG2, GH3 SK-N-SH) are all publically available } \\
\text { through the ATCC or other repositories. Primary tissues, including human cells } \\
\text { (red blood cell) can also be used. High purity radio-iodinated T3 and T4 is still } \\
\text { available. }\end{array}$ \\
\hline $\begin{array}{l}\text { Assay throughput } \\
\text { (high, medium, } \\
\text { low) }\end{array}$ & Low to Medium \\
\hline $\begin{array}{l}\text { Development } \\
\text { stage and } \\
\text { validation status - } \\
\text { further needs }\end{array}$ & $\begin{array}{l}\text { The assay is a research tool and results have been reported from many } \\
\text { investigators using different forms of the assay. It is apparently easy and the } \\
\text { technology is fairly basic although no attempt has been made to develop a } \\
\text { standardized protocol. Most of the work with inhibitors was performed well } \\
\text { before the identification of the transporter proteins so it is not clear which } \\
\text { transporter molecules are being inhibited and it is likely that the sum of thyroid } \\
\text { hormones transported into any given cell type results from the action of multiple } \\
\text { transporters. The relative levels of the various known transporter proteins will } \\
\text { need to be cha }\end{array}$ \\
\hline Chemicals tested & $\begin{array}{l}\text { A number of substances were shown to impair T3 uptake into the various cell } \\
\text { types: } \\
\text { Immortalized cells : Lormetazepam and triazolam (IC50 = 50 nM), Diazepam } \\
\text { (IC50 around } 50 \text { micromolar) in HepG2 cells; for other cells - Only } \\
\text { Lormetazepam tested but with same IC50 (Kragie and Doyle, 1992); Phloretin } \\
\text { (IC50 = } 88 \text { microM); HepG2 cells, (Movius, et al., 1989). Fenamate NSAIDs, } \\
\text { (meclofenamic acid ( } 25 \text { microM), mefenamic acid ( } 45 \text { microM), fenclofenac (69 }\end{array}$ \\
\hline
\end{tabular}




\begin{tabular}{|c|c|}
\hline & 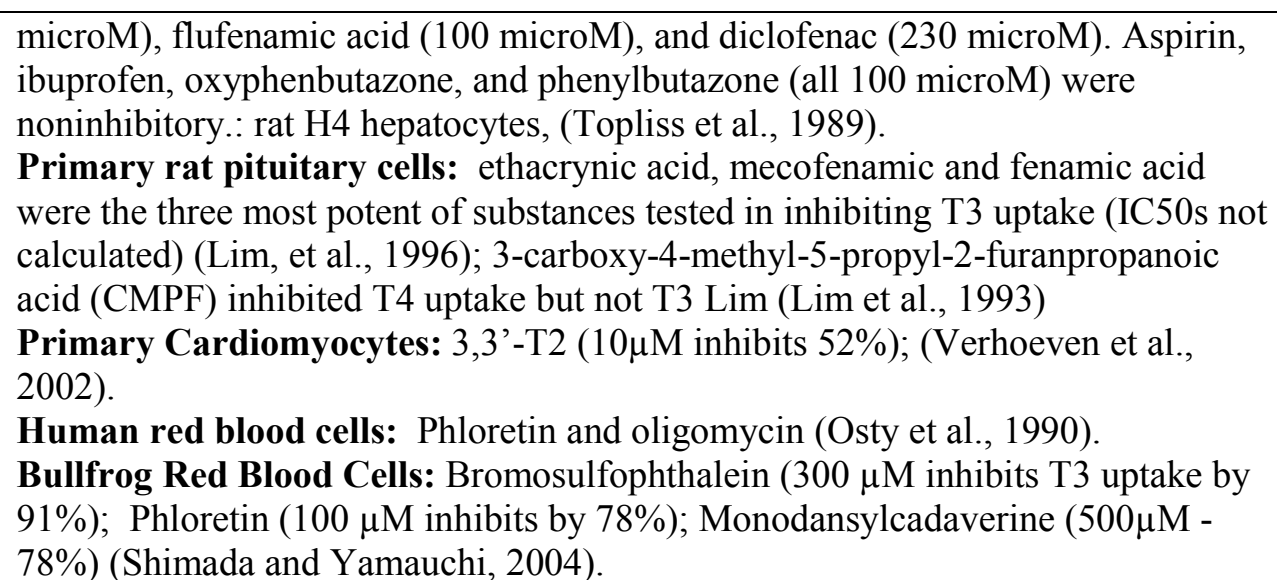 \\
\hline $\begin{array}{l}\text { Known } \\
\text { restrictions of the } \\
\text { assay }\end{array}$ & $\begin{array}{l}\text { The use of radiolabeled thyroid hormones presents health and safety concerns. } \\
\text { The short half-life of the isotope used to label thyroid hormones }\left({ }^{125} \mathrm{I}\right) \text { is short and } \\
\text { this creates logistical constraints for labs running the assay. The types and } \\
\text { relative activity of each transporter protein will need to be characterized for each } \\
\text { cell model used for the assay to assist in the interpretation of the results. } \\
\text { However, pre-labeled thyroid hormones are commercially available that may } \\
\text { help address the constraints. }\end{array}$ \\
\hline $\begin{array}{l}\text { Additional } \\
\text { information }\end{array}$ & $\begin{array}{l}\text { The assay is really very similar to the transient transfection assays in that they } \\
\text { incubate with labelled hormone until equilibrium and then lyse and count gamma } \\
\text { radiation. The cell types (at least HepG2) can be transiently transfected with } \\
\text { micro crystalin to enhance the signal (i.e. as described for the transient } \\
\text { transfection T3 uptake assay (Friesema, et al., 2008). Transfection with } \\
\text { transporter genes may be difficult to interpret given the endogenous activity of } \\
\text { constitutively expressed transporters in these models. }\end{array}$ \\
\hline $\begin{array}{l}\text { Are data from } \\
\text { studies publically } \\
\text { available }\end{array}$ & $\begin{array}{l}\text { Data from these studies are only publicly available through the published } \\
\text { literature. The authors have not been approached to see if they will provide the } \\
\text { raw data. }\end{array}$ \\
\hline $\begin{array}{l}\text { Assay included in } \\
\text { OECD DRP } 57 \\
\text { (OECD, 2006) or } \\
\text { DRP } 178 \text { (OECD, } \\
2012)\end{array}$ & ( \\
\hline $\begin{array}{l}\text { Proposed/potential } \\
\text { regulatory } \\
\text { purpose }\end{array}$ & $\begin{array}{l}\text { Given that the human and mouse KO for MCT8 - a major T3 -specific } \\
\text { transporter - show very marked disruption in TH physiology and developmental } \\
\text { abnormalities of central nervous system it is plausible that toxicant-induced } \\
\text { inhibition of the action of these molecules during critically-sensitive windows of } \\
\text { development information on inhibitory capability for any substance could predict } \\
\text { this. Although this assay may not distinguish the effects on specific transporters } \\
\text { or, at least, not until the transporters active in each of cell type used for the assay } \\
\text { have been clearly characterized, screening for substance effects on T3 transport } \\
\text { could potentially provide useful information about potential hazard to thyroid } \\
\text { physiology. An assay to screen this MAO would provide useful information for } \\
\text { hazard characterization. }\end{array}$ \\
\hline
\end{tabular}




\section{BLOCK \#6 ASSAYS}

\section{CELLULAR RESPONSES}

104. This block contains assays with the potential to evaluate disruption of thyroid hormone function by evaluating the effects of xenobiotics on the activation of the TH nuclear receptors (TRs) and consequently the cellular processes affected by its activation. Activation of TRs is evaluated by assessment of binding/interference with binding to the TRs, functional assessment of the activity of TR-responsive promoter elements (transactivation assays) or by direct assessment of the interaction of TRs with co-activators, co-repressors and other proteins that modulate its function.

\subsection{TR Binding Assays}

\begin{tabular}{|l|l|}
\hline Assay Name & $\begin{array}{l}\text { Competitive binding assay for thyroid hormone receptor in nuclear } \\
\text { fraction of MtT/E-2 cells }\end{array}$ \\
\hline $\begin{array}{l}\text { Molecular Initiation } \\
\text { Event or Key Event }\end{array}$ & Thyroid receptor binding \\
\hline $\begin{array}{l}\text { Endpoint(s)/ } \\
\text { purpose of the assay }\end{array}$ & $\begin{array}{l}\text { A nuclear fraction of MtT/E-2 cells was used as receptor source. Nuclear } \\
\text { fraction was incubated with 125I-T3 in the presence or absence of test } \\
\text { compounds and radiolabel bound to the receptor was determined. Displacement } \\
\text { by test compounds of radiolabelled 125I-T3 from the receptor (control =100\%) } \\
\text { is indicative of their affinity to the thyroid hormone receptor. }\end{array}$ \\
\hline $\begin{array}{l}\text { Major literature } \\
\text { citations }\end{array}$ & $\begin{array}{l}\text { Kitamura S. et al., Anti-thyroid hormonal activity of tetrabromobisphenol A, a } \\
\text { flame retardant, and related compounds: Affinity to the mammalian thyroid } \\
\text { hormone receptor, and effect on tadpole metamorphosis, in Life Sciences 76 } \\
\text { (2005), pp. 1589-1601 }\end{array}$ \\
\hline $\begin{array}{l}\text { Tissue, Cells or } \\
\text { Extract utilized in } \\
\text { assay and species } \\
\text { source }\end{array}$ & MtT/E-2 rat pituitary cell nuclear fraction \\
\hline $\begin{array}{l}\text { Laboratories } \\
\text { performing the } \\
\text { work }\end{array}$ & $\begin{array}{l}\text { Graduate School of Biomedical Sciences, Hiroshima University, Kasumi 1-2-3, } \\
\text { Minami-ku, Hiroshima 734-8551, Japan }\end{array}$ \\
\hline $\begin{array}{l}\text { Availability of } \\
\text { assay components } \\
\text { for wide use (public } \\
\text { or commercial, or } \\
\text { not available) }\end{array}$ & All materials seem to be available \\
\hline $\begin{array}{l}\text { Assay throughput } \\
\text { (high, medium, low) }\end{array}$ & Moderate \\
\hline $\begin{array}{l}\text { Development stage } \\
\text { and validation status } \\
\text { - further needs }\end{array}$ & $\begin{array}{l}\text { Test chemicals are TBBPA, TCBPA, BPA, 2,2-diphenyl-propane. This assay } \\
\text { shows clear interference of TBBPA, TCBPA but not with BPA. } \\
\text { The consistency of such results was observed through several other studies, } \\
\text { except for BPA which is known as antagonist as well in other studies. This } \\
\text { could be explained because of the use of nuclear fraction from GH3 cells which } \\
\text { contains both types of TRs, i.e. BPA is likely to inhibit one type of receptor and } \\
\text { not the other and thus lead to unclear result in this study. }\end{array}$ \\
\hline $\begin{array}{l}\text { Chemicals tested } \\
\text { Unimation }\end{array}$ \\
\hline
\end{tabular}




\begin{tabular}{|l|l|}
\hline $\begin{array}{l}\text { Known restrictions } \\
\text { of the assay }\end{array}$ & $\begin{array}{l}\text { When nuclear fraction from GH3 cells is used it is not possible to discriminate } \\
\text { between the TR } \alpha 1 \text { and TR } \beta 1 \\
\text { The design would be suitable for testing other TDC such as OH-BDEs }\end{array}$ \\
\hline $\begin{array}{l}\text { Additional } \\
\text { information }\end{array}$ & $\begin{array}{l}\text { This assay has been evaluated in an automated format in the developing } \\
\text { laboratory. Does not appear to be sensitive to solvent vehicle DMSO at high } \\
\text { concentrations. }\end{array}$ \\
\hline $\begin{array}{l}\text { Are data from } \\
\text { studies publically } \\
\text { available }\end{array}$ & Peer reviewed publication has been submitted (Paul et al. 2013). \\
\hline $\begin{array}{l}\text { Assay included in } \\
\text { OECD DRP 57 } \\
\text { (OECD, 2006) or } \\
\text { DRP 178 (OECD, } \\
\text { 2012) }\end{array}$ & Not in DRP \#57, Yes in DRP \#178 \\
\hline $\begin{array}{l}\text { Proposed/potential } \\
\text { regulatory purpose }\end{array}$ & This assay would be for example a first step in a stepwise assessment of TDCs \\
\hline
\end{tabular}




\begin{tabular}{|c|c|}
\hline Assay Name & TR alpha/beta activity using transient transfection in human cells \\
\hline $\begin{array}{l}\text { Molecular Initiation } \\
\text { Event or Key Event }\end{array}$ & Thyroid receptor binding using LBD in transient transfection \\
\hline $\begin{array}{l}\text { Endpoint(s)/ purpose } \\
\text { of the assay }\end{array}$ & $\begin{array}{l}\text { Human, zebrafish, and } X \text {. laevis TR } \alpha \text { activity was monitored on (GAL4RE) } \\
\text { Bglobin-luciferase construct using species-specific ligand-binding domain } \\
\text { (LBD) inserted in pSG5-GAL4-puro plasmid (Fini 2012). TR beta LBD was } \\
\text { used in Sun et al } 2008\end{array}$ \\
\hline $\begin{array}{l}\text { Major literature } \\
\text { citations }\end{array}$ & $\begin{array}{l}\text { Fini et aL, } 2012 \text { Toxicological Sciences } 125(2), 359-367 \text {; Sun et al., } 2008 \\
\text { Toxicology. } 2008 \text { Jul 30; 249(2-3):238-42. }\end{array}$ \\
\hline $\begin{array}{l}\text { Tissue, Cells or } \\
\text { Extract utilized in } \\
\text { assay and species } \\
\text { source }\end{array}$ & $\begin{array}{l}\text { Transient transfection assays were performed in HeLa cells using Jet-PEI } \\
\text { and activity of different chemicals were monitored via luciferase } \\
\text { quantification(Fini et al.2012). }\end{array}$ \\
\hline $\begin{array}{l}\text { Laboratories } \\
\text { performing the work }\end{array}$ & $\begin{array}{l}\text { DR Patrick Balaguer's laboratory. IRCM, Institut de Recherche en } \\
\text { Cancérologie de Montpellier, INSERM, U896, Université Montpellier1, } \\
\text { CRLC Val d'Aurelle Paul Lamarque, Montpellier 34298, France } \\
\text { DR Wong's laboratory. Key Laboratory of Reproductive Medicine, Institute } \\
\text { of Toxicology, Nanjing Medical University, Nanjing, China. }\end{array}$ \\
\hline $\begin{array}{l}\text { Availability of assay } \\
\text { components for wide } \\
\text { use (public or } \\
\text { commercial, or not } \\
\text { available) }\end{array}$ & All materials are available \\
\hline $\begin{array}{l}\text { Assay throughput } \\
\text { (high, medium, low) }\end{array}$ & High (384 well plates) \\
\hline $\begin{array}{l}\text { Development stage } \\
\text { and validation status - } \\
\text { further needs }\end{array}$ & In use \\
\hline Chemicals tested & $\begin{array}{l}\text { Test chemicals are TBBPA parent compound and major metabolite mono } \\
\text { sulphate TBBPA (Fini et al 2012) }\end{array}$ \\
\hline $\begin{array}{l}\text { Known restrictions of } \\
\text { the assay }\end{array}$ & $\begin{array}{l}\text { This assay is using LBD so it only reflects part of the nuclear receptor } \\
\text { interactions. }\end{array}$ \\
\hline Additional information & $\begin{array}{l}\text { This assay has been evaluated in an automated format in the developing } \\
\text { laboratory. }\end{array}$ \\
\hline $\begin{array}{l}\text { Are data from studies } \\
\text { publically available }\end{array}$ & Yes \\
\hline $\begin{array}{l}\text { Assay included in } \\
\text { OECD DRPs? }\end{array}$ & No, not included in OECD DRP 57 (2006) or OECD DRP 178 (2012) \\
\hline $\begin{array}{l}\text { Proposed/potential } \\
\text { regulatory purpose }\end{array}$ & B \\
\hline
\end{tabular}




\begin{tabular}{|c|c|}
\hline Assay Name & TR alpha/beta partner in cell free system \\
\hline $\begin{array}{l}\text { Molecular Initiation } \\
\text { Event or Key Event }\end{array}$ & $\begin{array}{l}\text { Corepressors such as nuclear hormone receptor corepressor (NCoR) are } \\
\text { recruited by unliganded TRs, whereas coactivators such as steroid receptor } \\
\text { coactivator-2 (SRC2) are recruited when triiodothyronine (T3) is bound to TRs. }\end{array}$ \\
\hline $\begin{array}{l}\text { Endpoint(s)/ } \\
\text { purpose of the assay }\end{array}$ & $\begin{array}{l}\text { Recombinant LBD of the human TR } \alpha 1 \text { isoform (hTR } \alpha 1 \mathrm{LBD} \text { ) was produced as } \\
\text { a fusion with glutathione S-transferase, and used to develop assays based on } \\
\text { fluorescence polarization to quantify the binding of either NCoR- or SRC2- } \\
\text { derived fluorescent peptides to the hTR } \alpha 1 \text { LBD (Lévy-Bimbot et al., 2012) }\end{array}$ \\
\hline $\begin{array}{l}\text { Major literature } \\
\text { citations }\end{array}$ & Zhuang et al.J Mol Graph Model. 2013 Jul;44:155-6 \\
\hline $\begin{array}{l}\text { Tissue, Cells or } \\
\text { Extract utilized in } \\
\text { assay and species } \\
\text { source }\end{array}$ & Lévy-Bimbot et al., 2012 Chemosphere. 2012 May;87(7):782-8 \\
\hline $\begin{array}{l}\text { Laboratories } \\
\text { performing the } \\
\text { work }\end{array}$ & Yves Lévy Univ Paris-Sud, Public Health-Environment, UMR 8079, France. \\
\hline $\begin{array}{l}\text { Availability of } \\
\text { assay components } \\
\text { for wide use }\end{array}$ & YES \\
\hline Assay throughput & High (384 well plates) \\
\hline $\begin{array}{l}\text { Development stage } \\
\text { and validation status } \\
\text { - further needs }\end{array}$ & In use \\
\hline Chemicals tested & $\begin{array}{l}\text { TBBPA interferes with LBD and allows NCOR release but does not bind to } \\
\text { SRC2 (Lévy-Bimbot et al., 2012) }\end{array}$ \\
\hline $\begin{array}{l}\text { Known restrictions } \\
\text { of the assay }\end{array}$ & $\begin{array}{l}\text { This assay is using LBD so it only reflects part of the nuclear receptor } \\
\text { interactions. }\end{array}$ \\
\hline $\begin{array}{l}\text { Additional } \\
\text { information }\end{array}$ & $\begin{array}{l}\text { The study was designed to probe the TR } \alpha 1 \text { conformational changes induced by } \\
\text { endocrine disrupting chemicals. Cell-free assays were based on binding of } \\
\text { transcriptional coregulator peptides to the ligand binding domain of TR } \alpha 1 \text {. The } \\
\text { thyroid disrupting chemical TBBPA promotes corepressor release but inhibits } \\
\text { T3-induced coactivator recruitment. TBBPA may disrupt the function of both } \\
\text { unliganded and T3-bound TR } \alpha 1 \text { by promoting an inactive TR } \alpha 1 \text { conformation. }\end{array}$ \\
\hline $\begin{array}{l}\text { Are data from } \\
\text { studies publically } \\
\text { available }\end{array}$ & YES \\
\hline $\begin{array}{l}\text { Assay included in } \\
\text { OECD DRPs? }\end{array}$ & No, not included in OECD DRP 57 (2006) or DRP 178 (2012) \\
\hline $\begin{array}{l}\text { Proposed/potential } \\
\text { regulatory purpose }\end{array}$ & $\mathrm{C}$ \\
\hline
\end{tabular}




\begin{tabular}{|c|c|}
\hline Assay Name & $\begin{array}{l}\text { Bacterial biosensors for screening isoform-selective ligands for human } \\
\text { thyroid receptors } \alpha-1 \text { and } \beta-1\end{array}$ \\
\hline $\begin{array}{l}\text { Molecular } \\
\text { Initiation Event or } \\
\text { Key Event }\end{array}$ & $\begin{array}{l}\text { The biosensor assay is an Escherichia coli (E. coli) growth-based technique. the } \\
\text { conformation of the TR LBD is linked to the activity of a thymidylate synthase } \\
\text { (TS) reporter enzyme }\end{array}$ \\
\hline $\begin{array}{l}\text { Endpoint }(\mathrm{s}) / \\
\text { purpose of the } \\
\text { assay }\end{array}$ & $\begin{array}{l}\text { TR } \alpha-1 \text { bacterial biosensor indicates the presence of thyroid active compounds } \\
\text { through their impacts on the growth of an engineered Escherichia coli strain in a } \\
\text { simple defined medium. }\end{array}$ \\
\hline $\begin{array}{l}\text { Major literature } \\
\text { citations }\end{array}$ & Gierach et al 2012 FEBS Open Bio. 2012 Aug 15; 2:247-53. \\
\hline $\begin{array}{l}\text { Tissue, Cells or } \\
\text { Extract utilized in } \\
\text { assay and species } \\
\text { source }\end{array}$ & E Coli \\
\hline $\begin{array}{l}\text { Laboratories } \\
\text { performing the } \\
\text { work }\end{array}$ & $\begin{array}{l}\text { David Wood Department of Chemical Engineering, Princeton University, } \\
\text { Princeton, NJ 08544,USA. }\end{array}$ \\
\hline $\begin{array}{l}\text { Availability of } \\
\text { assay components } \\
\text { for wide use } \\
\text { (public or } \\
\text { commercial, or } \\
\text { not available) }\end{array}$ & Public \\
\hline $\begin{array}{l}\text { Assay throughput } \\
\text { (high, medium, } \\
\text { low) }\end{array}$ & Medium \\
\hline $\begin{array}{l}\text { Development } \\
\text { stage and } \\
\text { validation status - } \\
\text { further needs }\end{array}$ & In development \\
\hline Chemicals tested & T3, Triac, GC-1 and KB-141 \\
\hline $\begin{array}{l}\text { Known } \\
\text { restrictions of the } \\
\text { assay }\end{array}$ & $\begin{array}{l}\text { This assay is using LBD so it only reflects part of the nuclear receptor } \\
\text { interactions. }\end{array}$ \\
\hline $\begin{array}{l}\text { Additional } \\
\text { information }\end{array}$ & See Gierach et al. 2012 \\
\hline $\begin{array}{l}\text { Are data from } \\
\text { studies publically } \\
\text { available }\end{array}$ & Yes \\
\hline $\begin{array}{l}\text { Assay included in } \\
\text { OECD DRPs? }\end{array}$ & No, not included in OECD DRP 57 (2006) or DRP 178 (2012) \\
\hline $\begin{array}{l}\text { Proposed/potential } \\
\text { regulatory } \\
\text { purpose }\end{array}$ & B \\
\hline
\end{tabular}




\begin{tabular}{|c|c|}
\hline Assay Name & Effects of TR Ligands on Hormone Dissociation Rates \\
\hline $\begin{array}{l}\text { Molecular } \\
\text { Initiation Event or } \\
\text { Key Event }\end{array}$ & $\begin{array}{l}\text { Ligands promote dissociation of radiolabeled bound hormone from the buried } \\
\text { ligand binding cavity (LBC) more rapidly than excess unlabeled hormone itself. }\end{array}$ \\
\hline $\begin{array}{l}\text { Endpoint(s)/ } \\
\text { purpose of the } \\
\text { assay }\end{array}$ & $\begin{array}{l}\text { Challenger ligands bind allosteric sites on the LBD to induce hormone } \\
\text { dissociation. } \mathrm{T}_{3} \text { binding affinities were determined by saturation binding assays }\end{array}$ \\
\hline $\begin{array}{l}\text { Major literature } \\
\text { citations }\end{array}$ & $\begin{array}{l}\text { Suzana T. Cunha Lima, et al., } 2009 \text { J Steroid Biochem Mol Biol. } 2009 \\
\text { November; 117(4-5): 125-131. }\end{array}$ \\
\hline $\begin{array}{l}\text { Tissue, Cells or } \\
\text { Extract utilized in } \\
\text { assay and species } \\
\text { source }\end{array}$ & TRs were incubated overnight with saturating $(1 \mathrm{nM}){ }^{125} \mathrm{I}-\mathrm{T}_{3}$ at $4^{\circ} \mathrm{C}$ No cells \\
\hline $\begin{array}{l}\text { Laboratories } \\
\text { performing the } \\
\text { work }\end{array}$ & $\begin{array}{l}\text { Department of General Biology, Biology Institute, Federal University of Bahia, } \\
\text { Campus of Ondina, Salvador, BA, Brazil. }\end{array}$ \\
\hline $\begin{array}{l}\text { Availability of } \\
\text { assay components } \\
\text { for wide use } \\
\text { (public or } \\
\text { commercial, or } \\
\text { not available) }\end{array}$ & Public but need radioactivity \\
\hline $\begin{array}{l}\text { Assay throughput } \\
\text { (high, medium, } \\
\text { low) }\end{array}$ & Medium \\
\hline $\begin{array}{l}\text { Development } \\
\text { stage and } \\
\text { validation status - } \\
\text { further needs }\end{array}$ & In development \\
\hline Chemicals tested & Agonists T3, T4, GC1, GC24 antagonists NH-3, NH-5, NH-7 \\
\hline $\begin{array}{l}\text { Known } \\
\text { restrictions of the } \\
\text { assay }\end{array}$ & High concentrations used. Low sensitivity and radioactivity necessary \\
\hline $\begin{array}{l}\text { Additional } \\
\text { information }\end{array}$ & See Cunha Lima et al/, 2012 \\
\hline $\begin{array}{l}\text { Are data from } \\
\text { studies publically } \\
\text { available }\end{array}$ & Yes \\
\hline $\begin{array}{l}\text { Assay included in } \\
\text { OECD DRPs? }\end{array}$ & No, not included in OECD DRP 57 (2006) or DRP 178 (2012) \\
\hline $\begin{array}{l}\text { Proposed/potential } \\
\text { regulatory } \\
\text { purpose }\end{array}$ & $\mathrm{C}$ \\
\hline
\end{tabular}




\subsection{TR Transactivation Assays}

105. These are reporter gene assays that address overall activation of the TR or specifically evaluate the function of co-activators or co-repressors of the TR. Representative examples are presented here. Analysis of these types of assays in Part 1 includes 10 individual assays.

\begin{tabular}{|c|c|}
\hline Assay Name & $\begin{array}{l}\text { Reporter gene assay using GH3-TRE cell line (luciferase gene reporter } \\
\text { assay) }\end{array}$ \\
\hline $\begin{array}{l}\text { Molecular } \\
\text { Initiation Event or } \\
\text { Key Event }\end{array}$ & Thyroid receptor activation \\
\hline $\begin{array}{l}\text { Endpoint(s)/ } \\
\text { purpose of the } \\
\text { assay }\end{array}$ & $\begin{array}{l}\text { This assay measures the Luciferase activity (induction) in GH3 cells stably } \\
\text { transfected with a pGL4CP-SV40-2xtaDR } 4 \text { construct (GH3.TRE-Luc). } \\
\text { In parallel, cell toxicity is assessed by resazurine method (reduction of resazurine } \\
\text { to the fluorescent resofurin depending on the cell viability). }\end{array}$ \\
\hline $\begin{array}{l}\text { Major literature } \\
\text { citations }\end{array}$ & $\begin{array}{l}\text { Jaime Freitas, Patricia Cano, Christina Craig-Veit, Michael L Goodson, J. David } \\
\text { Furlow, Albertinka J. Murk, Feb 2011. Detection of thyroid homrone receptor } \\
\text { disruptors by a novel stable in vitro reporter gene assay. Toxicology in Vitro. } \\
\text { Vol 25(1): } 257-266\end{array}$ \\
\hline $\begin{array}{l}\text { Tissue, Cells or } \\
\text { Extract utilized in } \\
\text { assay and species } \\
\text { source }\end{array}$ & Rat pituitary tumor (GH3) cell line \\
\hline $\begin{array}{l}\text { Laboratories } \\
\text { performing the } \\
\text { work }\end{array}$ & $\begin{array}{l}\text { jaime.freitas.wur.nl (Wageningen University, Tox Dept, De Dreijen, Tuinlaan 5, } \\
\text { Building 320, Wageningen, } 6703 \mathrm{HE} \text {, The netherlands.) }\end{array}$ \\
\hline $\begin{array}{l}\text { Availability of } \\
\text { assay components } \\
\text { for wide use } \\
\text { (public or } \\
\text { commercial, or } \\
\text { not available) }\end{array}$ & No \\
\hline $\begin{array}{l}\text { Assay throughput } \\
\text { (high, medium, } \\
\text { low) }\end{array}$ & High/Medium \\
\hline $\begin{array}{l}\text { Development } \\
\text { stage and } \\
\text { validation status - } \\
\text { further needs }\end{array}$ & $\begin{array}{l}\text { Assay in the research phase / It has undergone internal validation (see publication } \\
\text { listed), not yet used by multiple laboratories. } \\
\text { This assay has been validated for HTS screening by NCGC via their assay } \\
\text { optimization and development program. The assay is currently being used to } \\
\text { screen } \sim 8 \mathrm{k} \text { chemicals for the Tox } 21 \text { program. }\end{array}$ \\
\hline Chemicals tested & $\begin{array}{l}\text { T3, T4, TRIAC, TETRAC, OH-PBDEs, OH-PCBs; the study proved they are } \\
\text { agonists } \\
\text { Amiodarone, BPA, TCBPA, TBBPA; the study proved they are antagonists }\end{array}$ \\
\hline $\begin{array}{l}\text { Known } \\
\text { restrictions of the } \\
\text { assay }\end{array}$ & \\
\hline $\begin{array}{l}\text { Additional } \\
\text { information }\end{array}$ & $\begin{array}{l}\text { This assay shows ambiguous effect of amiodarone (previously considered as } \\
\text { antagonistic) because it appears as an agonistic here. May interfere in a different } \\
\text { mechanism of action (inhibit cellular efflux pumps). }\end{array}$ \\
\hline
\end{tabular}




\begin{tabular}{|c|c|}
\hline $\begin{array}{l}\text { Are data from } \\
\text { studies publically } \\
\text { available }\end{array}$ & \\
\hline $\begin{array}{l}\text { Assay included in } \\
\text { OECD DRPs? }\end{array}$ & No, not included in OECD DRP 57 (2006) or DRP 178 (2012) \\
\hline $\begin{array}{l}\text { Proposed/potential } \\
\text { regulatory } \\
\text { purpose }\end{array}$ & $\begin{array}{l}\text { Assay could provide a quick screen for chemicals that have potential thyroid } \\
\text { hormone receptor activity. Could provide screening level information that would } \\
\text { inform which higher level assays should be utilized. Can provide mode of action } \\
\text { information that would be useful for hazard identification. }\end{array}$ \\
\hline
\end{tabular}




\subsection{Assays that Evaluate Interactions of TR With Other Regulatory Proteins}

106. Assays are available in the literature but could not be analysed at present and are therefore not included in this document.

\begin{tabular}{|c|c|}
\hline Assay Name & $\begin{array}{l}\text { Reporter gene assay using Mt T/E-2 cell line (no hormone secreting cell } \\
\text { line) }\end{array}$ \\
\hline $\begin{array}{l}\text { Molecular Initiation } \\
\text { Event or Key Event }\end{array}$ & TH receptor activation $(\mathrm{TR} \alpha 1, \mathrm{TR} \beta)$ \\
\hline $\begin{array}{l}\text { Endpoint(s)/ purpose } \\
\text { of the assay }\end{array}$ & This assay measures the test compound effect through the Luciferase activity \\
\hline $\begin{array}{l}\text { Major literature } \\
\text { citations }\end{array}$ & $\begin{array}{l}\text { Matsubara et al., An improved thyroid hormone reporter assay to determine } \\
\text { the thyroid hormone-like activity of amiodarone, bithionol, closantel and } \\
\text { rafoxanide, in Toxicol Lett. 2012 Jan 5;208(1):30-35 }\end{array}$ \\
\hline $\begin{array}{l}\text { Tissue, Cells or } \\
\text { Extract utilized in } \\
\text { assay and species } \\
\text { source }\end{array}$ & Rat pituitary tumor cell line \\
\hline $\begin{array}{l}\text { Laboratories } \\
\text { performing the work }\end{array}$ & Author : Nariaki Fujimoto, mfjm@hiroshima-u.ac.jp \\
\hline $\begin{array}{l}\text { Availability of assay } \\
\text { components for wide } \\
\text { use (public or } \\
\text { commercial, or not } \\
\text { available) }\end{array}$ & Yes (cell lines available from Sigma Chemical) \\
\hline $\begin{array}{l}\text { Assay throughput } \\
\text { (high, medium, low) }\end{array}$ & Medium (48-well plates), suitable for High \\
\hline $\begin{array}{l}\text { Development stage } \\
\text { and validation status } \\
\text { - further needs }\end{array}$ & $\begin{array}{l}\text { Cell lines utilized usually in ER assays }(1999,2002) \text { and in TR assays }(2004) \text {. } \\
\text { Validation needed }\end{array}$ \\
\hline Chemicals tested & $\begin{array}{l}\text { Has high sensitivity: ability to detect } \mathrm{T} 3 \text { at } 10^{-11} \mathrm{M} \text {. The ED used was TBBPA. } \\
\text { Chemicals tested are in one hand pharmaceuticals (amiodarone, closantel, } \\
\text { bithionol, rafoxanide) and in the other hand industrial products TBBPA which } \\
\text { is a flame retardant. This study confirms amiodarone is not real antagonistic, } \\
\text { as it was suspected in Freitas et al. study. }\end{array}$ \\
\hline $\begin{array}{l}\text { Known restrictions } \\
\text { of the assay }\end{array}$ & \\
\hline $\begin{array}{l}\text { Additional } \\
\text { information }\end{array}$ & \\
\hline $\begin{array}{l}\text { Are data from } \\
\text { studies publically } \\
\text { available }\end{array}$ & \\
\hline $\begin{array}{l}\text { Assay included in } \\
\text { OECD DRPs? }\end{array}$ & No, not included in OECD DRP 57 (2006) or DRP 178 (2012) \\
\hline $\begin{array}{l}\text { Proposed/potential } \\
\text { regulatory purpose }\end{array}$ & $\begin{array}{l}\text { Could be used for assessing Thyroid Disrupters Chemicals (TDCs) that have } \\
\text { hormone-like activity on thyroid receptor. This assay has high sensitivity, } \\
\text { higher than other known assays }\left(10^{-11} \mathrm{M} \text { vs. } 10^{-8} \mathrm{M}\right) \text {. }\end{array}$ \\
\hline
\end{tabular}




\section{BLOCK \#7 ASSAYS}

\section{RELEVANT SHORT-TERM ASSAYS INEGRATING MULTIPLE MOAS}

107. This block includes in vivo assays using zebrafish larvaeand thyroid gland organ explants cultures. The larvae assay is performed under in vitro conditions at very early stages of development and represent relevant alternatives to the traditional in vivo testing. and were thus included in the scoping effort. An assay using Xenopus laevis embryos is already included in the OECD work plan (Project 2.39) and therefore is not described here.

\subsection{Zebrafish Assays}

\begin{tabular}{|c|c|}
\hline Assay Name & Zebrafish Eleutheroembryo Screen \\
\hline $\begin{array}{l}\text { Molecular } \\
\text { Initiating/Key } \\
\text { Event }\end{array}$ & Impaired $\mathrm{T} 4$ synthesis \\
\hline $\begin{array}{l}\text { Endpoint(s)/ } \\
\text { purpose of the } \\
\text { assay }\end{array}$ & $\begin{array}{l}\text { Detection of relative follicular T4 levels using immunohistochemistry techniques } \\
\text { of the whole eleutheroembryo with an antibody to T4. Signal is detected using } \\
\text { fluorescence. }\end{array}$ \\
\hline $\begin{array}{l}\text { Major literature } \\
\text { citations }\end{array}$ & $\begin{array}{l}\text { Raluda et al., 2012. Reproductive Toxicology, 33, 188-197; Thienpont et al., } \\
\text { 2011, Env. Sci. Technol. 45, 7525-7532; Raldúa and Babin. 2009. Env. Sci. } \\
\text { Technol. 43, 6844-6850. }\end{array}$ \\
\hline $\begin{array}{l}\text { Tissue, Cells or } \\
\text { Extract utilized in } \\
\text { assay and species } \\
\text { source }\end{array}$ & Zebrafish larvae (Danio rerio) \\
\hline $\begin{array}{l}\text { Laboratories } \\
\text { performing the } \\
\text { work }\end{array}$ & $\begin{array}{l}\text { Institute of Environmental Assessment and Water Research (IDÆA-CSIC), Jordi } \\
\text { Girona 18, } 08034 \text {, Barcelona, Spain. } \\
\text { University of Bordeaux, Talence, France }\end{array}$ \\
\hline $\begin{array}{l}\text { Availability of } \\
\text { assay components } \\
\text { for wide use }\end{array}$ & Zebrafish and antibodies required for the assay are commercially available. \\
\hline Assay throughput & Low \\
\hline $\begin{array}{l}\text { Development } \\
\text { stage and } \\
\text { validation status - } \\
\text { further needs }\end{array}$ & $\begin{array}{l}\text { The assay is at the standardization stage in } 2 \text { labs. About } 24 \text { chemicals have been } \\
\text { tested, variability has decreased. Standardization of the protocol and possibly } \\
\text { transfer to another lab, and assessment of additional chemicals would be needed } \\
\text { for pre-validation status. }\end{array}$ \\
\hline Chemicals tested & $\begin{array}{l}\text { Amiodarone hydrochloride, MMI, MeHg (II) chloride, KClO4, PTU, atrazine, } \\
\text { 2,4-D, DDT, fenoxycarb, 4-NP, KSCN, NaNO3, NaBr, genistein, resorcinol, } \\
\text { phloroglucinol, sulfamethoxazole, bisphenol A, benzophenone-2, benzophenone- } \\
\text { 3, linuron, pyrazole, amitrole, DDT, ETU, mancozeb, TBBPA, BDE-209, } \\
\text { HBCD, PFOS, PFOA, BDE-47 }\end{array}$ \\
\hline $\begin{array}{l}\text { Known } \\
\text { restrictions of the } \\
\text { assay }\end{array}$ & $\begin{array}{l}\text { Use in research and development; does not address mechanism of action but } \\
\text { captures several possible mechanisms; is low throughput because the image } \\
\text { analysis is not automatable; the signal is from a two-dimensional representation } \\
\text { of a three-dimentional phenomenon (image capture of a whole-mount stained } \\
\text { organ). }\end{array}$ \\
\hline $\begin{array}{l}\text { Additional } \\
\text { information }\end{array}$ & \\
\hline Data publically & Yes, in published literature. \\
\hline
\end{tabular}




\begin{tabular}{|l|l|}
\hline available? & \\
\hline $\begin{array}{l}\text { Assay included in } \\
\text { OECD DRPs? }\end{array}$ & Not in DRP 57 but Raldúa and Babin, 2009 is included in the DRP 178. \\
\hline $\begin{array}{l}\text { Proposed/potential } \\
\text { regulatory } \\
\text { purpose }\end{array}$ & Screen for T4 synthesis inhibition \\
\hline
\end{tabular}




\subsection{Thyroid Gland Explant Culture}

\begin{tabular}{|c|c|}
\hline Assay Name & Xenopus laevis thyroid gland explant culture \\
\hline $\begin{array}{l}\text { Molecular } \\
\text { Initiating/Key } \\
\text { Event }\end{array}$ & $\begin{array}{l}\text { Multiple initiating events such as thyroid peroxidase inhibition, iodide uptake } \\
\text { inhibition, among others, may lead to changes in the measured endpoint of T4 } \\
\text { release. }\end{array}$ \\
\hline $\begin{array}{l}\text { Endpoint(s)/ } \\
\text { purpose of the } \\
\text { assay }\end{array}$ & $\begin{array}{l}\text { This assay measures the release of T4 by thyroid glands from pro-metamorphic } \\
X \text {. laevis into the culture media in response to stimulation by bovine TSH. The } \\
\text { purpose of the assay is to detect the ability of chemicals to inhibit the synthesis } \\
\text { and release of T4 from these glands. }\end{array}$ \\
\hline $\begin{array}{l}\text { Major literature } \\
\text { citations }\end{array}$ & Hornung et al. 2010. Toxicological Sciences, 118, 42-51. \\
\hline $\begin{array}{l}\text { Tissue, Cells or } \\
\text { Extract utilized in } \\
\text { assay and species } \\
\text { source }\end{array}$ & Thyroid glands from pro-metamorphic $X$. laevis \\
\hline $\begin{array}{l}\text { Laboratories } \\
\text { performing the } \\
\text { work }\end{array}$ & US EPA, Mid-Continent Ecology Division, Duluth, MN \\
\hline $\begin{array}{l}\text { Availability of } \\
\text { assay components } \\
\text { for wide use }\end{array}$ & Organisms and assay components are all commercially available \\
\hline Assay throughput & Low. The assay as currently designed takes 8 days in culture. \\
\hline $\begin{array}{l}\text { Development } \\
\text { stage and } \\
\text { validation status - } \\
\text { further needs }\end{array}$ & Research; requires further standardization/validation. \\
\hline Chemicals tested & Methimazole, propylthiouracil, perchlorate \\
\hline $\begin{array}{l}\text { Known } \\
\text { restrictions of the } \\
\text { assay }\end{array}$ & $\begin{array}{l}\text { Additional research is needed to increase confidence in mechanistic interpretation } \\
\text { of T4 release inhibition. Further research is in progress to address methods to } \\
\text { identify when reduction in T4 release is a result of impact at a thyroid-specific } \\
\text { molecular initiating event versus reduced T4 release due to general toxicity. }\end{array}$ \\
\hline \multicolumn{2}{|l|}{$\begin{array}{l}\text { Additional } \\
\text { information }\end{array}$} \\
\hline $\begin{array}{l}\text { Data publically } \\
\text { available? }\end{array}$ & Data are available in the published literature. \\
\hline $\begin{array}{l}\text { Assay included in } \\
\text { OECD DRPs? }\end{array}$ & Assay is included in DRP 178 \\
\hline $\begin{array}{l}\text { Proposed/potential } \\
\text { regulatory } \\
\text { purpose }\end{array}$ & $\begin{array}{l}\text { TSH stimulation of the thyroid gland to release T4 is a conserved response } \\
\text { among vertebrates, and thyroid hormone release to maintain proper circulating } \\
\text { levels of the hormone is critical for normal physiological function of peripheral } \\
\text { tissues. Thus an assay that can measure the effect of chemicals to limit the ability } \\
\text { of the gland to release T4 in response to TSH stimulation has potential for use in } \\
\text { a regulatory framework. }\end{array}$ \\
\hline
\end{tabular}




\section{BLOCK \#8 ASSAYS}

\section{INTEGRATIVE CELLULAR ASSAYS}

108. This block contains assays with the potential to evaluate disruption of thyroid hormone function by evaluating the effects of xenobiotics on TH- or THR- mediated cell proliferation and differentiation.

\subsection{T-screen Assays}

\begin{tabular}{|c|c|}
\hline Assay Name & T-screen assay using GH3-cell line \\
\hline $\begin{array}{l}\text { Molecular } \\
\text { Initiation Event or } \\
\text { Key Event }\end{array}$ & Cell proliferation in response to TR activation by $\mathrm{T} 3 \mathrm{and} /$ or $\mathrm{T} 4$ \\
\hline $\begin{array}{l}\text { Endpoint(s)/ } \\
\text { purpose of the } \\
\text { assay }\end{array}$ & $\begin{array}{l}\text { This assay measures cell proliferation in response to activation of the thyroid } \\
\text { receptor in GH3 cells. Cell proliferation assessment is performed by the use of } \\
\text { the blue resazurin which is reduced mitochondrial resazurin/diaphorase/NADPH } \\
\text { in GH-3 cells in to pink fluorescent resofurin. Decrease in fluorescence reflects } \\
\text { less cell proliferation. }\end{array}$ \\
\hline $\begin{array}{l}\text { Major literature } \\
\text { citations }\end{array}$ & $\begin{array}{l}\text { Hamers et al., Toxicological Sciences, 2006, 92(1), 157-173; Taxvig et al. } \\
\text { Toxicological Sciences, 2008, 106, 206-213; Taxvig et al. Toxicology and } \\
\text { Applied Pharmacology, 2011, 250, 263-269; Ghisari \&. Bonefeld-Jorgensen } \\
\text { (2005). Molecular and Cellular Endocrinology, Vol. 244(1-2), 31-41. }\end{array}$ \\
\hline $\begin{array}{l}\text { Tissue, Cells or } \\
\text { Extract utilized in } \\
\text { assay and species } \\
\text { source }\end{array}$ & Rat pituitary tumor (GH3-cell line) \\
\hline $\begin{array}{l}\text { Laboratories } \\
\text { performing the } \\
\text { work }\end{array}$ & $\begin{array}{l}\text { Institute for Environmental Studies, Vrije Universiteit Amsterdam, } 108 \mathrm{HV} \\
\text { Amsterdam, The Netherlands. } \\
\text { National Food Institute, Technical University of Denmark, Department of } \\
\text { Toxicology and Risk Assessment, DK-2860 Søborg, Denmark }\end{array}$ \\
\hline $\begin{array}{l}\text { Availability of } \\
\text { assay components } \\
\text { for wide use }\end{array}$ & \\
\hline Assay throughput & Medium to high \\
\hline $\begin{array}{l}\text { Development } \\
\text { stage and } \\
\text { validation status - } \\
\text { further needs }\end{array}$ & Research stage. \\
\hline Chemicals tested & $\begin{array}{l}31 \text { chemicals including brominated flame retardants such as BDEs, TBBPA, } \\
\text { HBCDs }\end{array}$ \\
\hline $\begin{array}{l}\text { Known } \\
\text { restrictions of the } \\
\text { assay }\end{array}$ & $\begin{array}{l}\text { This assay studies only the competition between the chemicals and the T3 } \\
\text { hormone, to be exhaustive competition between chemicals and T4 shall be } \\
\text { assessed too (even if it is already known that T4 has less affinity for the TR than } \\
\text { T3). } \\
\text { The endpoint is non-specific in that there are a number of processes that can be } \\
\text { affected, in addition to T3 signaling, that will increase or decrease cell } \\
\text { proliferation (eg., cytotoxicity will decrease fluorescence). } \\
\text { The use of fluorescence indicators make this assay not useful for classes of } \\
\text { chemicals that have fluorescence properties. }\end{array}$ \\
\hline
\end{tabular}




\begin{tabular}{|c|c|}
\hline $\begin{array}{l}\text { Additional } \\
\text { information }\end{array}$ & $\begin{array}{l}\text { Taxvig et al (2008) cell toxicity was assessed (resazurin reduction within } \\
\text { mitochondria). } \\
\text { Taxvig et al (2011) include testing of effect of metabolism by use of human S9 } \\
\text { liver fraction or PCB induced rat microsomes. }\end{array}$ \\
\hline $\begin{array}{l}\text { Are data from } \\
\text { studies publically } \\
\text { available }\end{array}$ & \\
\hline $\begin{array}{l}\text { Assay included in } \\
\text { OECD DRPs? }\end{array}$ & Yes, included in DRP\#178 (OECD, 2012): Taxvig et al (2011) \\
\hline $\begin{array}{l}\text { Proposed/potential } \\
\text { regulatory } \\
\text { purpose }\end{array}$ & $\begin{array}{l}\text { This assay allows screening on chemicals that have the potential ability to bind } \\
\text { the thyroid receptors. Cell toxicity has to be assessed in parallel in order to } \\
\text { confirm the relevancy of chemicals that display an antagonistic activity }\end{array}$ \\
\hline
\end{tabular}




\subsection{Developmental Neurotoxicity in vitro Assay}

\begin{tabular}{|c|c|}
\hline Assay Name & Human neural progenitor cells (hNPCs) assay \\
\hline $\begin{array}{l}\text { Molecular } \\
\text { Initiation Event or } \\
\text { Key Event }\end{array}$ & Cell proliferation, migration and differentiation \\
\hline $\begin{array}{l}\text { Endpoint(s)/ } \\
\text { purpose of the } \\
\text { assay }\end{array}$ & $\begin{array}{l}\text { This assay evaluates multiple endpoints including cell proliferation, } \\
\text { differentiation and migration. Proliferation is indexed by measuring size of the } \\
\text { sphere. Differentiation of oligodendrocytes assessed in cell cultures that have } \\
\text { been allowed to differentiate for several days, exposed to fixed in } 2 \% \\
\text { paraformaldehyde, mounted on slides, and subjected to immunohistochemistry. } \\
\text { Oligodendrocyte-positive cells are counted and expressed as number of } \\
\text { cells/sphere. Relative nestin expression is assessed as a marker of } \\
\text { undifferentiated hNPC. Cell migration is assessed when growth factors are } \\
\text { withdrawn. Over course of several days cells move from the sphere both radially } \\
\text { and tangentially. Migration is measured by determining the distance from the } \\
\text { edge of the sphere to the furthest migrated cells } 48 \text {-hours after initiation of } \\
\text { differentiation at four defined positions on the sphere. Cell viability is measured } \\
\text { by mitochondrial reductase activity, released LDH, and coloration by Trypan } \\
\text { colorant. }\end{array}$ \\
\hline $\begin{array}{l}\text { Major literature } \\
\text { citations }\end{array}$ & Schreiber et al, Environmental Health Perspectives, 2010, 118: 572-578 \\
\hline $\begin{array}{l}\text { Tissue, Cells, } \\
\text { Extract utilized in } \\
\text { assay and species } \\
\text { source }\end{array}$ & Primary fetal human neural progenitor cells \\
\hline $\begin{array}{l}\text { Laboratories } \\
\text { performing the } \\
\text { work }\end{array}$ & $\begin{array}{l}\text { Institut für umweltmedizinische Forschung gGmbH an der Heinrich Heine- } \\
\text { Universität, Toxicology, Auf'm Hennekamp 50, } 40225 \text { Düsseldorf, Germany }\end{array}$ \\
\hline $\begin{array}{l}\text { Availability of } \\
\text { assay components } \\
\text { for wide use }\end{array}$ & $\begin{array}{l}\text { Yes, commercially available, but may be restrictive in terms of quantity. May } \\
\text { also be ethical issues }\end{array}$ \\
\hline Assay throughput & Low-Medium \\
\hline $\begin{array}{l}\text { Development } \\
\text { stage and } \\
\text { validation status - } \\
\text { further needs }\end{array}$ & Research phase \\
\hline Chemicals tested & BDE-47 and BDE-99 \\
\hline $\begin{array}{l}\text { Known } \\
\text { restrictions of the } \\
\text { assay }\end{array}$ & $\begin{array}{l}\text { Disruption of developmental processes probed in this assay can occur through } \\
\text { many non-thyroid mediated pathways so effects identified may not be selective } \\
\text { for thyroid disruption. The age at which the donor cells are harvested can also } \\
\text { impact the outcome, i.e., distance hNPCs migrate may be robust but can vary } \\
\text { widely dependent on the age of the donor cells (gestational vs postnatal). There } \\
\text { may be ethical and availability concerns due to the use of fetal human cells. } \\
\text { Rodent-based NPC neurosphere models may alleviate some of these restrictions } \\
\text { and be more appropriate for large scale cytotoxicity assess. }\end{array}$ \\
\hline $\begin{array}{l}\text { Additional } \\
\text { information }\end{array}$ & $\begin{array}{l}\text { Alm et al. (2008) Neurotoxicology } 29: 628-637 \text { provides in vivo data that were } \\
\text { confirmed by this current in vitro study. Cell-toxicity is taken into account in this } \\
\text { assay. }\end{array}$ \\
\hline Are data from & Yes, published literature \\
\hline
\end{tabular}




\begin{tabular}{|l|l|}
\hline $\begin{array}{l}\text { studies publically } \\
\text { available }\end{array}$ & \\
\hline $\begin{array}{l}\text { Assay included in } \\
\text { OECD DRPs? }\end{array}$ & Yes in OECD DRP 178 (2012) \\
\hline $\begin{array}{l}\text { Proposed/potential } \\
\text { regulatory } \\
\text { purpose }\end{array}$ & $\begin{array}{l}\text { Evaluation of developmental neurotoxicity based on alterations in cell } \\
\text { proliferation, differentiation and migration induced by thyroid disruptors }\end{array}$ \\
\hline
\end{tabular}




\section{REFERENCES}

Andrews, P. et al. (2002), "Sensitive detection of the endocrine effects of the estrogen analogue ethinylestradiol using a modified enhanced subacute rat study protocol (OECD test guideline no. 407)", Archives of Toxicology, Vol. 76, No. 4, pp. 194-202.

Andrews, P. et al. (2001), "Feasibility and potential gains of enhancing the subacute rat study protocol (OECD test guideline no. 407) by additional parameters selected to determine endocrine modulation. A pre-validation study to determine endocrine-mediated effects of the antiandrogenic drug flutamide", Archives of Toxicology, Vol. 75, No. 2, pp. 65-73.

Bock, K.W. (1974), "Oxidation of Barbiturates and the Glucuronidation of 1-Naphtol in Perfused Rat Liver and in Microsomes”, Naunyn-Schmiedberg's Arch. Pharmacol Vol. 283 pp. 319-330.

Butt, C. M. et al. (2011), "Halogenated Phenolic Contaminants Inhibit the In Vitro Activity of the Thyroid-Regulating Deiodinases in Human Liver," Toxicological Sciences Vol. 124 No. 2 pp. 339347.

Cao, J. et al. (2010), "Structure based investigation on the binding interaction of hydroxylated polybrominated diphenyl etherswith thyroxine transport proteins", Toxicology Vol. 277 No. 1-3 pp. 20-28.

Chang, H. C. and D. R. Doerge (2000), "Dietary genistein inactivates rat thyroid peroxidase in vivo without an apparent hypothyroid effect", Toxicology and Applied Pharmacology Vol. 168, No. 3 pp. 244-252.

Cunha Lima S.T. et al. (2009), "Differential Effects of TR Ligands on Hormone Dissociation Rates: Evidence for Multiple Ligand Entry/Exit Pathways", The Journal of Steroid Biochemistry and Molecular Biology, Vol. 117, No. 4-5, pp. 125-131.

Decherf, S. et al. (2010), "Disruption of thyroid hormone-dependent hypothalamic set-points by environmental contaminants", Molecular and Cellular Endocrinology, Vol. 323 No. 2 pp. 172-82.

Divi, R. L. and D. R. Doerge (1996), "Inhibition of thyroid peroxidase by dietary flavonoids", Chemical Research and Toxicology Vol. 9, No. 1 pp. 16-23.

Divi, R. L., H. C. Chang and D. R. Doerge (1997), "Anti-thyroid isoflavones from soybean: isolation, characterization, and mechanisms of action," Biochemical Pharmacology Vol. 54, No. 10 pp. 10871096.

Doerge.D.R. and R.S. Takazawa (1990), "Mechanism of peroxidase inhibition by ethylenethiourea", Chemical Research in Toxicology Vol. 3, No. 2 pp. 98-101.

Fekete, C. and R.M. Lechan (2007), "Negative feedback regulation of hypophysiotropic thyrotropinreleasing hormone (TRH) synthesizing neurons: role of neuronal afferents and type 2 deiodinase", Frontiers in Neuroendocrinology, Vol. 28 No. 2-3 pp. 97-114.

Freyberger, A., H. Ellinger-Ziegelbauer and F. Krötlinger (2007), "Evaluation of the rodent Hershberger bioassay: Testing of coded chemicals and supplementary molecular-biological and biochemical investigations", Toxicology, Vol. 239, No. 1-2, pp. 77-88. 
Freyberger, A. and H. J. Ahr (2006), "Studies on the goitrogenic mechanism of action of N,N,N',N'tetramethylthiourea", Toxicology Vol. 217, No. 2-3 pp. 169-175.

Friesema, E. C. et al. (2003), "Identification of monocarboxylate transporter 8 as a specific thyroid hormone transporter", The Journal of Biology and Chemistry Vol. 278 No. 41 pp. 40128-40135.

Friesema, E. C. et al. (2008), "Effective cellular uptake and efflux of thyroid hormone by human monocarboxylate transporter 10", Molecular Endocrinology Vol. 22 No. 6 pp. 1357-69.

Ghisari, M. and E.C. Bonefeld-Jorgensen (2005), "Impact of environmental chemicals on the thyroid hormone function in pituitary rat GH3 cells", Molecular and Cellular Endocrinology, Vol. 244 No. 1-2 pp. 31-41.

Hamers, T. et al. (2006), "In Vitro Profiling of the Endocrine-disrupting Potency of Brominated Flame Retardants", Toxicological Sciences, Vol. 92 No. 1 pp. 157-173.

Heldin, N.E. et al. (1994), "Thyrotropin (TSH)-induced receptor internalization in nonthyroidal cells transfected with a human TSH-receptor complementary deoxyribonucleic acid", Endocrinology Vol. 134 No. 5 pp. 2032-6.

Hinkle, P.M., D.G. Lewis and T.L. Greer (1980), "Thyrotropin-releasing hormone-receptor interaction in GH3 pituitary cells”, Endocrinology Vol. 106 No. 3 pp. 1000-5.

Hollenberg, A.N., T. Monden, and F.E. Wondisford (1995), "Ligand-independent and -dependent functions of thyroid hormone receptor isoforms depend upon their distinct amino termini", The Journal of Biological Chemistry, Vol. 270 No. 24 pp. 14274-80.

Hosoya, T. (1963), "Effect of various reagents including antithyroid compounds upon the activity of thyroid peroxidase", The Journal of Biochemistry Vol. 53 pp. 381-388.

Kinne, A. et al. (2009), "Surface translocation and tri-iodothyronine uptake of mutant MCT8 proteins are cell type-dependent”, Journal of Molecular Endocrinology Vol. 43 No. 6 pp. 263-271.

Lecat-Guillet, N. et al. (2007), “A 96-Well Automated RadioiodideUptake Assay for Sodium.Iodide Symporter Inhibitor, Assay and Drug Development Technologies Vol. 5 No. 4 pp. 535-540.

Lezoualc'h, F. et al (1992), "Assignment of the beta-thyroid hormone receptor to 3,5,3'triiodothyronine-dependent inhibition of transcription from the thyrotropin-releasing hormone promoter in chick hypothalamic neurons", Molecular Endocrinology. Vol. 6 No. 11 pp. 1797-804.

Marchesini, G. R. et al. (2008), "Biosensor discovery of thyroxine transport disrupting chemicals", Toxicology and Applied Pharmacology Vol. 232 No. 1 pp. 150-160.

Montano, M. et al. (2012), "New approaches assess the TTR binding capacity of bio-activated thyroid hormone disruptors", Toxicological Sciences, Vol. 130 No. 1 pp. 94-105.

Paul, K. B. et al. (2013), "Cross-species analysis of thyroperoxidase inhibition by xenobiotics demonstrates conservation of response between pig and rat", Toxicology Vol. 312C pp. 97-107.

Perrone, C.E. et al. (2004), "Embryonic turkey liver: activities of biotransforming enzymes and activities of DNA-reactive carcinogens", Archives of Toxicology, Vol.78, No. 10, pp. 589-598. 
Radovic B., C. Schmutzler and J. Kôhrle (2005), "Xanthohumol stimulates iodide uptake in rat thyroid-derived FRTL-5 cells", Molecular Nutrition \& Food Research Vol. 49, No. 9 pp. 832-836.

Raldúa, D. and P.J. Babin (2009), "Simple, rapid zebrafish larva bioassay for assessing the potential of chemical pollutants and drugs to disrupt thyroid gland function", Environmental Science and Technology Vol. 43 No. 17 pp. 6844-6850.

Raluda, D., B. Theinpont and P.J. Babin (2012), "Zebrafish eleutheroembryos as an alternative system for screening chemicals disrupting the mammalian thuyroid gland morphogenesis and function", Reproductive Toxicology, Vol. 33 No.2 pp. 188-197.

Renko, K. et al. (2012), "Identification of iopanoic acid as substrate of type 1 deiodinase by a novel nonradioactive iodide-release assay”, Endocrinology Vol. 153 No. 5 pp. 2506-13.

Schmutzler, C. A. et al. (2007), "The ultraviolet filter benzophenone 2 interferes with the thyroid hormone axis in rats and is a potent in vitro inhibitor of human recombinant thyroid peroxidase", Endocrinology Vol. 148, No. 6 pp. 2835-2844.

Schmutzler, C. et al. (2007), "Endocrine disruptors and the thyroid gland--a combined in vitro and in vivo analysis of potential new biomarkers", Environmental Health Perspective Vol. 115 Suppl. 1 pp.77-83.

Schoenmakers $\mathrm{CHH}$, et al. (1992) "Species differences in liver type I iodothyronine deiodinase", Biochimica et Biophysica Acta Vol. 1121 pp. 160-166.

Schreiber, T. et al. (2010), "Polybrominated Diphenyl Ethers Induce Developmental Neurotoxicity in a Human in Vitro Model: Evidence for Endocrine Disruption", Environmental Health Perspectives Vol. 118 No.4 pp. 572-578.

Sue, M. et al. (2012), "Propylthiouracil increases sodium/iodide symporter gene expression and iodide uptake in rat thyroid cells in the absence of TSH", Thyroid Vol. 22 No. 8 pp. 844-52.

Takayama, S. et al. (1986), "Antithyroid effects of propylthiouracil and sulfamonomethoxine in rats and monkeys", Toxicology and Applied Pharmacology Vol. 82 No.2 pp. 191-199.

Taurog, A. (1970), "Thyroid peroxidase and thyroxine biosynthesis", Recent Prog Hormone Res Vol. 26, pp. 189-247.

Taxvig, C. et al. (2008), "Do parabens have the ability to interfere with steroidogenesis?" Toxicological Sciences, Vol. 106 No. 1 pp. 206-213

Taxvig, C. et al. (2011), "Use of external metabolizing systems when testing for endocrine disruption in the T-screen assay", Toxicology and Applied Pharmacology, Vol. 250 No. 3 pp. 263-269.

Thienpont, B. et al. (2011), "Zebrafish eleutheroembryos provide a suitable vertebrate model for screening chemicals that impair thyroid hormone synthesis", Environmental Science and Technology Vol. 45 No. 17 pp. 7525-7532.

Tong et al.(2017), "In vitro Glucuronidation of Thyroxine and Triiodothyronine by Liver Microsomes and Recombinant Human UDP-Glucuronosyltransferases", Drug Metabolism and Disposition Vol. 35, pp2203-2210 
Waltz, L., Pillette L. and Ambroise Y. (2010), "A non-radioactive iodide uptake assay for Sodium iodide symporter function”, Analytical Biochemistry Vol. 396 No. 1 pp. 91-5.

Westholm, D. E. et al. (2009), "Competitive inhibition of organic anion transporting polypeptide 1c1mediated thyroxine transport by the fenamate class of nonsteroidal antiinflammatory drugs", Endocrinology Vol. 150 No. 2 pp.1025-32. 


\begin{abstract}
ANNEX 1
OECD Conceptual Framework for Testing and Assessment of Endocrine Disrupters (as revised in 2012)

The OECD Conceptual Framework for Testing and Assessment of Endocrine Disrupters (as revised in 2012) lists the OECD Test Guidelines and standardized test methods available, under development or proposed that can be used to evaluate chemicals for endocrine disruption. The Conceptual Framework is intended to provide a guide to the tests available which can provide information for endocrine disrupters' assessment but is not intended to be a testing strategy. Furthermore, this Conceptual Framework does not include evaluation of exposure; however this should be included when deciding whether further testing is needed. Further information regarding the use and interpretation of these tests is available in Guidance Document No. 150.
\end{abstract}




\begin{tabular}{|c|c|}
\hline & Mammalian and non-mammalian Toxicology \\
\hline \begin{tabular}{l}
\multicolumn{3}{c}{ Level 1 } \\
Existing Data and Non-Test \\
Information
\end{tabular} & 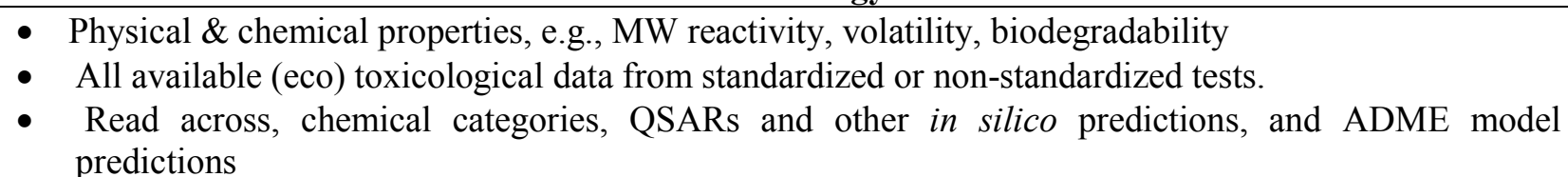 \\
\hline
\end{tabular}

\begin{tabular}{|l|}
\hline \multicolumn{2}{|c|}{ Level 2 } \\
In vitro assays providing data \\
about selected endocrine \\
mechanism(s) / pathways(s) \\
(Mammalian and non- \\
mammalian methods) \\
\end{tabular}

- Estrogen or androgen receptor binding affinity

- Estrogen receptor transactivation (OECD TG 455 - OECD TG 457)

- Androgen or thyroid transactivation (If/when TGs are available)

- Steroidogenesis in vitro (OECD TG 456)

- MCF-7 cell proliferation assays (ER ant/agonist)

- Other assays as appropriate

\begin{tabular}{|l|l|ll|}
\hline & \multicolumn{2}{|c|}{ Mammalian Toxicology } \\
\hline $\begin{array}{l}\text { In vivo assays providing data } \\
\text { about selected endocrine } \\
\text { mechanism(s) / pathway(s) }\end{array}$ & & $\bullet$ & Uterotrophic assay (OECD TG 440) \\
& & & \\
\hline
\end{tabular}

\section{Level 4}

In vivo assays providing data on adverse effects on endocrine relevant endpoints ${ }^{2}$
- Repeated dose 28-day study (OECD TG 407)

- Repeated dose 90-day study (OECD TG 408)

- 1-generation reproduction toxicity study (OECD TG 415)

- Male pubertal assay (see GD 150, Chapter
Non-Mammalian Toxicology

- Xenopus embryo thyroid signalling assay (When/if TG is available)

- Amphibian metamorphosis assay (OECD TG 231)

- Fish Reproductive Screening Assay (OECD TG 229)

- Fish Screening Assay (OECD TG 230)

- Androgenized female stickleback screen (GD 140)

- Fish sexual development test (OECD TG 234)

- Fish Reproduction Partial Lifecycle Test (when/If TG is Available)

- Larval Amphibian Growth \& Development Assay (when TG is available)

- Avian Reproduction Assay (OECD TG 206) 


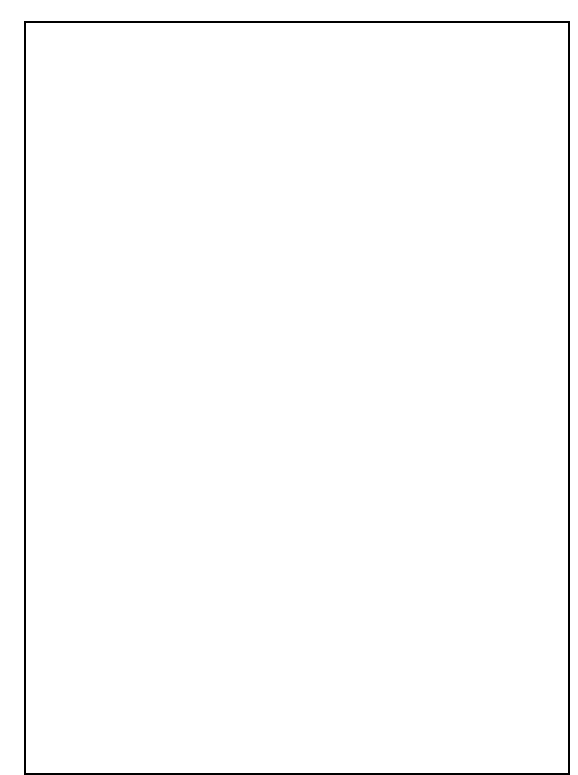

\section{C4.3)}

- Female pubertal assay (see GD 150, Chapter $\mathrm{C} 4.4)^{3}$

- Intact adult male endocrine screening assay (see GD 150, Chapter Annex 2.5)

- Prenatal developmental toxicity study (OECD TG 414)

- Chronic toxicity and carcinogenicity studies (OECD TG 451-3)

- Reproductive screening test (OECD TG 421 if enhanced)

- Combined 28-day/reproductive screening assay (OECD TG 422 if enhanced)

- Developmental neurotoxicity (OECD TG 426)

\section{Level 5}

In vivo assays providing more comprehensive data on adverse effects on endocrine relevant endpoints over more extensive parts of the life cycle of the organism $^{2}$
- Extended one-generation reproductive toxicity study (OECD TG 443)

- 2-Generation reproduction toxicity study (OECD TG 416 most recent update)
- Mollusc Partial Lifecycle Assays (when TG is available) ${ }^{4}$

- $\quad$ Chironomid Toxicity Test (TG 218-219) ${ }^{4}$

- Daphnia Reproduction Test (with male induction) (OECD TG 211)

- Earthworm Reproduction Test (OECD TG 222) ${ }^{4}$

- Enchytraeid Reproduction Test (OECD TG 220) ${ }^{4}$

- Sediment Water Lumbriculus Toxicity Test Using Spiked Sediment (OECD TG 225) ${ }^{4}$

- Predatory mite reproduction test in soil (OECD TG 226) $^{4}$

- Collembolan Reproduction Test in Soil (TG OECD 232) ${ }^{4}$

- FLCTT (Fish LifeCycle Toxicity Test) (when TG is available)

- Medaka Multigeneration Test (MMGT) (when TG is available)

- Avian 2 generation reproductive toxicity assay (when TG is available)

- Mysid Life Cycle Toxicity Test (when TG is ${\text { available })^{4}}^{4}$

- Copepod Reproduction and Development Test (when TG is available) ${ }^{4}$

- Sediment Water Chironomid Life Cycle Toxicity Test (OECD TG 233) ${ }^{4}$

- Mollusc Full Lifecycle Assays (when TG is available $)^{4}$

- Daphnia Multigeneration Assay (if TG is available) $^{4}$ 


\section{ENV/JM/MONO(2014)23}

${ }^{1}$ Some assays may also provide some evidence of adverse effects.

2 Effects can be sensitive to more than one mechanism and may be due to non-ED mechanisms.

${ }^{3}$ Depending on the guideline/protocol used, the fact that a substance may interact with a hormone system in these assays does not necessarily mean that when the substance is used it will cause adverse effects in humans or ecological systems.

${ }^{4}$ At present, the available invertebrate assays solely involve apical endpoints which are able to respond to some endocrine disrupters and some non-EDs. Those in Level 4 are partial lifecycle tests, while those in Level 5 are full- or multiple lifecycle tests.

${ }^{5}$ The Extended one-generation reproductive Toxicity Study (OECD TG 443) is preferable for detecting endocrine disruption because it provides an evaluation of a number of endocrine endpoints in the juvenile and adult F1, which are not included in the 2-generation study (OECD TG 416) adopted in 2001

\section{Notes to the OECD Revised Conceptual Framework}

Note 1: Entering at all levels and exiting at all levels is possible and depends upon the nature of existing information and needs for testing and assessment.

Note 2: The assessment of each chemical should be made on a case by case basis, taking into account all available information.

Note 3: The framework should not be considered as all inclusive at the present time. At levels 2, 3, 4 and 5 it includes assays that are either available or for which validation is under way. With respect to the latter, these are provisionally included. 